\author{
Universidade de São Paulo \\ Instituto de Física - Instituto de Química \\ Instituto de Biociências - Faculdade de Educação
}

\title{
Física das Radiações: uma proposta para o Ensino Médio
}

\author{
Wellington Batista de Sousa
}

Orientador: Prof. Dr. Elio Carlos Ricardo

Dissertação de mestrado apresentada ao Instituto de Física, ao Instituto de Química, ao Instituto de Biociências e a Faculdade de Educação da Universidade de São Paulo, para a obtenção do título de Mestre em Ensino de Ciências.

Comissão Examinadora:

Prof. Dr. Elio Carlos Ricardo (Orientador) - USP

Profa. Dra. Jesuína Lopez de Almeida Pacca - USP

Prof. Dr. Mikael Frank Rezende Junior - UNIFEI 


\section{FICHA CATALOGRÁFICA}

Preparada pelo Serviço de Biblioteca e Informação do Instituto de Física da Universidade de São Paulo

Sousa, Wellington Batista

Física das Radiações: Uma Proposta para o Ensino Médio. São Paulo, 2009.

Dissertação (Mestrado) - Universidade de São Paulo. Instituto de Física e Faculdade de Educação.

Orientador: Prof. Dr. Elio Carlos Ricardo

Área de Concentração: Ensino de Ciências.

Unitermos: 1. Ensino ; 2. Física ; 3. Física Moderna; 4.

Física das Radiações. 


\section{AGRADECIMENTOS}

Agradeço primeiramente a Deus pela oportunidade única de poder chegar até onde cheguei e por me dar a família que tenho, afinal, eles sempre foram a razão da minha luta. Aos meus pais, Francisco e Irene, pessoas ímpares em minha formação e que sempre me apoiaram e incentivaram desde meus primeiros dias de ingresso na escola, fica registrado o meu agradecimento e o meu profundo amor por vocês, pois sem vocês nada disso poderia ter acontecido. Aos meus irmãos, Wesley e Verônica, com quem compartilhei um pouco da minha aflição ao realizar esse trabalho, agradeço-os pela paciência e companheirismo nos momentos mais difíceis.

Um agradecimento muito particular à professora Nobuko Ueta que desde o início da minha caminhada no programa de mestrado, esteve presente me aconselhando, incentivando e apoiando para que eu realizasse um bom trabalho. Agradeço muito a ela também pelas muitas vezes que fez a revisão dos textos e atividades, de uma maneira totalmente companheira e preocupada com o meu crescimento, fornecendo comentários e sugestões que só vieram a enriquecer a minha formação. A você professora Nobuko o meu mais sincero agradecimento e respeito.

Ao professor Mauricio Pietrocola que durante parte desse trabalho me orientou na execução das minhas atividades, com sugestões e conselhos aos quais me acrescentaram muito, fornecendo-me subsídios para que eu pudesse ingressar nesse caminho da pesquisa em educação, o meu muito obrigado pela confiança depositada.

Aos colegas que sempre me ajudaram diretamente ou indiretamente para que eu pudesse realizar esse sonho de um dia tornar-me mestre, Josias, João, Osvaldo, Maria Cristina, André, Armando, Guaraciba, Dejair, Maxwell, Guilherme, Lúcia, Thaís, Ivã e demais colegas do LAPEF, o meu muito obrigado. Vocês não imaginam como me ajudaram a crescer como pessoa e profissional.

Aos professores que contribuíram na minha formação ao longo destes muitos anos, o meu mais sincero respeito e admiração, pois através deles descobri que o conhecimento enobrece e dignifica o homem. 
Ao parceiro de todas as horas, conselheiro e amigo fiel, Seiji, também o meu muito obrigado, por ouvir os meus desabafos e inquietudes, dizendo-me uma palavra de conforto e de siga em frente, sempre nos momentos mais difíceis e de aparente falta de perspectiva de um final feliz.

A minha esposa Estela e meu filho (paçoca) que entenderam a minha ausência durante os momentos em que estive à frente da escrita desse trabalho, apoiando-me para que eu o concluísse. Amo todos vocês e sem vocês seria difícil viver. Aos meus colegas Adriano e Ronaldo que me incentivaram sempre na realização deste sonho.

Ao professor Elio Ricardo que aceitou o desafio de me orientar e fez de maneira única a revisão dos textos, fornecendo-me uma diretriz para que o meu trabalho tivesse uma excelente qualidade no texto e nas idéias apresentadas, mostrando a sua qualidade de pesquisador, professor e orientador, o meu muito obrigado.

O meu mais sincero agradecimento a todos,

Wellington Batista de Sousa. 


\section{RESUMO}

A sociedade vem questionando os conteúdos presentes no currículo de ciências, quanto ao "por que" e "para que" ensiná-los. Isso ocorre também dentro do ambiente escolar. Atualmente, o ensino de ciências tem acontecido de maneira bastante desconexa da realidade de nossos alunos, afinal, este ensino não tem apresentado inovações ou trazido temas atualizados para as discussões que ocorrem no ambiente da sala de aula.

Apresentamos neste trabalho uma proposta de atualização curricular do ensino de ciências através da inserção de tópicos de Física Moderna e Contemporânea, com base na proposta curricular inserida nos PCNEM e PCNEM+ para a disciplina de Física. Nossa proposta consiste em uma seqüência didática de um curso de Física das Radiações voltado ao Ensino Médio, onde se utilizam as noções de "marcadores" e "marcadores-estruturantes", desenvolvidas no contexto da teoria da Transposição Didática, para delinear as atividades que acreditamos serem essenciais para que esta nova seqüência de ensino seja exeqüível. 


\section{ABSTRACT}

The society has questioned what should be taught in science learning, including both "why" and "what for" some subjects should be taught. This kind of discussion occurs also inside the educational environment. Presently the science teaching is not connected to the reality of the student, because teaching has not related to scientific innovations, no updated themes are discussed in the classroom.

In this work the curricular updating is inserted through the inclusion of Modern and Contemporary Physics topics, as suggested in the PCNEM and PCNEM+. This proposal consists of a didactic sequence of a course on Radiations Physics appropriated to the high school teaching. The concept of "markers" and "structurating-markers" is discussed within the Didactic Transposition Theory. "Markers" are established through the proposed activities, which are supposed to be the essential ones to the learning sequence. 


\section{APRESENTAÇÃO}

Esse trabalho apresenta uma proposta de ensino da Física das Radiações para alunos do Ensino Médio, onde se tem como objetivos a identificação, estudo e entendimento das diferentes formas de radiações existentes na natureza, sua interação com a matéria e possíveis formas de detecção.

Assim, foi elaborada uma proposta de um curso de Física das Radiações composto de textos e atividades adaptados a uma linguagem mais acessível à sala de aula e que auxiliam a compreensão dos conceitos estudados. Desta forma, busca-se modificar o cenário atual do ensino de Física, procurando trazer para o ambiente escolar e das aulas de Física tópicos que estejam relacionados com a Física Moderna e Contemporânea, em particular, a Física das Radiações.

A proposta foi aplicada em um colégio estadual da zona sul de São Paulo, em uma turma de alunos do período noturno, na modalidade EJA, por um professor e membro integrante do Laboratório de Pesquisa em Ensino de Física (LAPEF) da Faculdade de Educação da Universidade de São Paulo.

Para analisar a estrutura do curso e a sua exeqüibilidade, foi utilizada uma ferramenta de análise chamada Transposição Didática, ferramenta esta muito utilizada na Didática da Matemática, e que já havia se mostrado útil na avaliação de propostas de curso em momentos anteriores (BROCKINGTON 2005 e SIQUEIRA 2006).

Assim, utilizamos a Transposição Didática e suas regras como um referencial para analisar e refazer os caminhos percorridos pelos saberes, procurando entender como o savoir savant (saber sábio) transforma-se em saber ensinado, e como ocorre o processo de transformação desse saber, desde a sua origem, até chegar ao ambiente escolar e, finalmente, à sala de aula, o que corresponde a uma didatização dos saberes escolares.

Como resultado deste trabalho, apresentamos o sucesso obtido com a elaboração e aplicação da proposta, indicando que é possível levar a Física das Radiações para sala de aula, no sentido de uma proposta inovadora, tanto em relação ao currículo quanto à metodologia. 


\section{SUMÁRIO}

\section{Agradecimentos}

Resumo

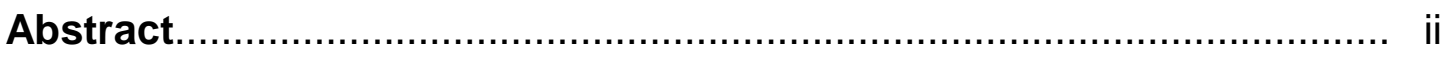

Apresentação......................................................................... ii

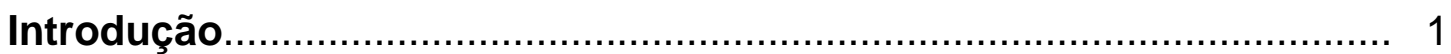

1 - Descrição dos capítulos.................................................................... 5

2 - A necessidade do Ensino da FMC............................................. 6

3 - Qual tema escolher? .................................................................. 12

4 - Por que a Transposição Didática? ................................................. 16

Capítulo 1 - A Metodologia da Pesquisa ............................................ 19

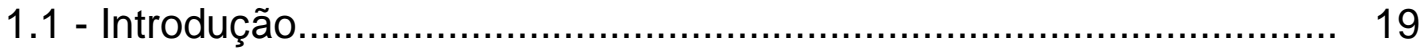

1.2 - A escolha da metodologia da pesquisa.......................................... 20

1.3 - A coleta de dados e a técnica da triangulação.................................. 23

1.3.1 - Descrição dos instrumentos de coleta de dados....................... 25

1.3.2 - Caracterização do local de aplicação....................................... 26

1.3.3 - Caracterização da turma..................................................... 27

1.4 - Caracterizando o professor...................................................... 28

Capítulo 2 - A Didatização dos Saberes Escolares................................. 31

2.1 - Introdução............................................................................ 31

2.2 - O saber e suas adaptações para o ambiente escolar........................ 32

2.3 - A Transposição Didática........................................................... 33

2.4 - Caracterizando os saberes escolares presentes na Transposição

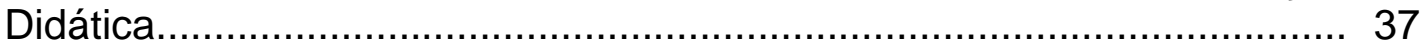

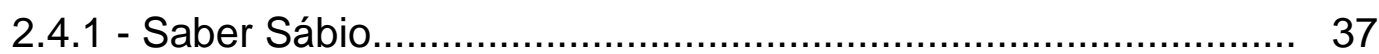

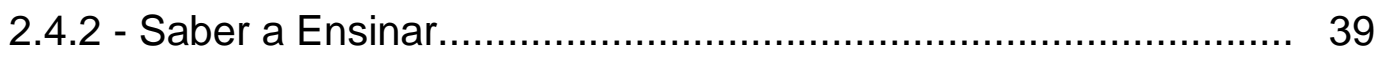

2.4.3 - Saber Ensinado............................................................ 41

2.4.4 - Analisando a sobrevivência do saber..................................... 43

2.4.5 - As regras da Transposição Didática...................................... 45

2.5 - A Física das Radiações à luz da Transposição Didática................... 47

Capítulo 3 - O Curso de Física das Radiações........................................ 50

3.1 - Introdução........................................................................ 50

3.2 - A escolha dos conteúdos e a seqüência didática do curso................. 51

3.3 - As atividades do curso de Física das Radiações............................... 58 
4.1 - Introdução........................................................................ 60

4.2 - Definindo os Marcadores-Estruturantes no curso de Física das

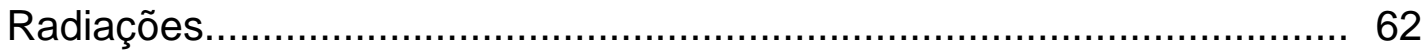

4.3 - Os marcadores-estruturantes e sua análise.................................. 64

4.3.1 - Primeiro Marcador-Estruturante.............................................. 65

4.3.1.1 - Descrição da atividade ................................................... 65

4.3.1.2 - A análise do primeiro marcador-estruturante....................... 68

4.3.2 - Segundo Marcador-Estruturante........................................... 79

4.3.2.1 - Descrição da atividade .................................................... 79

4.3.2.2 - A análise do segundo marcador-estruturante..................... 80

4.3.3 - Terceiro Marcador-Estruturante................................................. 87

4.3.3.1 - Descrição da atividade .................................................... 88

4.3.3.2 - A análise do terceiro marcador-estruturante....................... 89

4.3.4 - Quarto Marcador-Estruturante............................................. 95

4.3.4.1 - Descrição da atividade....................................................... 95

4.3.4.2 - A análise do quarto marcador-estruturante...................... 97

4.4 - Analisando a estrutura do curso através do questionário.................. 103

Considerações Finais ..................................................................... 107

Referências Bibliográficas ................................................................ 113

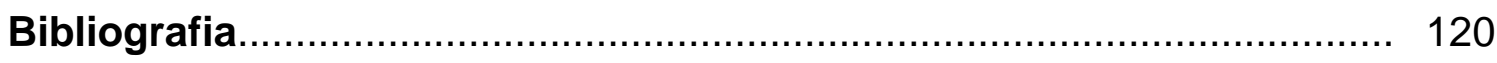

Anexos 


\section{INTRODUÇÃO}

O mundo está cada vez mais rodeado de inovações tecnológicas, as quais tornaram o uso de muitos objetos uma simples brincadeira de criança. Muitas tecnologias foram surgindo e se tornando barateadas, devido ao consumismo desenfreado.

Com o conhecimento não foi diferente. Este acabou se propagando de uma forma mais veloz, principalmente com o surgimento das novas mídias, em especial, com a ampliação da Internet. Assim, hoje temos o conhecimento e as tecnologias espalhadas em todos e por todos os lugares, entretanto nem sempre bem compreendidos.

Percebemos isso a partir de uma simples constatação: a de que toda essa imensidão de conhecimentos espalhados e de tecnologias barateadas, até o presente momento, ainda não possibilitaram de forma concreta que a nossa sociedade, dita tecnológica, tornasse-se mais informada, bem formada, capacitada e consciente de seus deveres e direitos como cidadãos.

Ao que parece, temos uma crise instaurada quanto ao que fazer com todo esse volume de informação; como filtrá-lo, o que aproveitar, o que excluir, entre outros questionamentos. Isso tem se refletido em todas as áreas do conhecimento, inclusive nas escolas, ou seja, toda a tecnologia criada para facilitar nosso cotidiano, em nada, ou muito pouco, tem alterado o modelo de ensino das ciências em nossas salas de aula, uma vez que essas tecnologias e novas teorias decorridas desses avanços não têm sido levadas para as salas de aula. A tecnologia ainda é vista como um mero produto de consumo e status.

Podemos citar como exemplo dessas implicações sociais, o Bluetooth ${ }^{1}$, uma tecnologia que existe atualmente em muitos dispositivos como os aparelhos de celular, e que permite a troca de arquivos diversos, principalmente de áudio em um formato compactado, geralmente em $\mathrm{mp}^{2}$, de maneira muito prática e rápida, muito cultuado entre os nossos jovens

\footnotetext{
${ }^{1}$ Bluetooth: é uma especificação industrial para áreas de redes pessoais sem fio, onde é possível conectar e trocar informações entre dispositivos através de uma freqüência de rádio de curto alcance.

${ }^{2}$ Mp3: Sigla para MPEG-1/2 Audio Layer 3 e que consiste em um método para compressão de áudio com perdas quase imperceptíveis ao ouvido humano.
} 
portadores de celulares cada vez mais avançados. Essa tecnologia se encontra cada vez mais difundida na população, afinal é "legal" ter um celular que toque mp3 e tenha o Bluetooth, ou melhor, é muito bom e prático ter um aparelho que consiga reproduzir esse formato de música, possibilitando o transporte de muitas músicas de uma maneira bastante simples, e que também consiga transferir e receber arquivos do tipo mp3 de outros aparelhos.

Entretanto, a chegada dessa tecnologia e a sua conseqüente distribuição junto a diversos dispositivos como os aparelhos de celular, não implicou necessariamente na melhoria da educação de nossos estudantes que, embora se identifiquem com tal tecnologia, esta ainda não Ihes permitiu uma melhor compreensão do mundo que os rodeia, nem favoreceu um maior contato com o ensino de ciências. Talvez, tenha havido apenas uma mera aproximação com as novas mídias e recursos que as áreas da informática e comunicação puderam fornecer a eles nesses últimos anos sem, todavia, despertar necessidades intelectuais.

Assim, vivemos em pleno século XXI com muitos avanços tecnológicos, muitas facilidades de um mundo moderno, porém com pessoas que não conseguem entender o que realmente acontece ao seu redor, isto é, com pessoas que não dominam essa cultura científica e tecnológica, apenas usufruem das vantagens que elas proporcionam, sem enxergar o quanto a ciência está envolvida em todos esses processos. São consumidores que utilizam as tecnologias, mas que são desprovidos de conhecimentos científicos que os permitam entendê-las, ou quando de posse desses conhecimentos, não conseguem aplicá-los na vida cotidiana.

Diante disso, deveríamos desenvolver competências básicas já na escola para que o estudante se torne um cidadão e possa fazer uso de sua cidadania, e isso implica desenvolver em nossos alunos durante a Educação Básica, em particular no Ensino Médio e no componente curricular física, uma série de elementos que estão descritos nos Parâmetros Curriculares Nacionais do Ensino Médio (PCNEM):

Espera-se que o ensino de física, na escola média, contribua para a formação de uma cultura científica efetiva, que permita ao indivíduo a interpretação dos fatos, fenômenos e processos naturais, situando e dimensionando a interação do ser 
humano com a natureza como parte da própria natureza em transformação. (BRASIL, 1999, p. 229)

Mostrar a importância da física e do seu papel em nosso cotidiano corresponde a um grande desafio para nós educadores, mas que certamente terá que ser vencido, afinal é necessário que a ciência contribua de alguma forma para o crescimento pessoal de nossos indivíduos enquanto cidadãos, levando-os a compreendê-la em todos os seus aspectos.

Uma provável justificativa para tal descompasso no ensino de ciências, talvez esteja, em parte, nos próprios currículos de ciências que se aplicam nas escolas, que já vêm há algum tempo sendo alvo de muitas críticas por parte de agentes ligados à educação, que procuraram, através de reformulações, a melhoria do ensino em nossas escolas. Essas críticas podem ser vistas nos Parâmetros Curriculares Nacionais para o Ensino Médio (PCNEM e PCNEM+) e nas Diretrizes Curriculares para o Ensino Médio (DCNEM). Tais documentos buscam uma atualização do currículo na tentativa de fazer a educação ser voltada para o dia a dia, ou seja, que contribua para uma melhor formação do cidadão, permitindo-lhe entender tanto os fenômenos naturais quanto os tecnológicos:

A Física deve apresentar-se, portanto, como um conjunto de competências específicas que permitam perceber e lidar com os fenômenos naturais e tecnológicos, presentes tanto no cotidiano mais imediato quanto na compreensão do universo distante, a partir de princípios, leis e modelos por ela construídos. (BRASIL, 2002, p. 56)

Assim, podemos constatar que a física, que deveria ser levada para a sala de aula, deveria permitir aos estudantes uma conexão com os fenômenos naturais e tecnológicos que já ocorreram e estão ocorrendo atualmente, o que Ihes forneceria um contato crítico com o mundo em que vivem, pois o que atualmente encontramos em nossas salas de aula ainda está muito desvinculado da sua realidade.

Podemos afirmar então que a física trazida para a sala de aula acaba se transformando, em sua maior parte, em exercícios meramente repetitivos, pouco ou quase nada relacionados com a vivência do aluno e que não condizem com o seu tempo, pois continuamos ensinando a física de séculos 
atrás, mas vivendo em um mundo moderno, rodeado de tecnologias, cujo desenvolvimento da ciência, principalmente da física, tem proporcionado uma nova revolução dos objetos ao nosso redor.

É fato que os currículos e as práticas que encontramos nas escolas brasileiras são muito tradicionais e pouco têm se alterado nas últimas décadas, o que leva Terrazzan a fazer o seguinte comentário:

Os currículos das escolas brasileiras têm permanecido tradicionais e inalterados em sua estrutura básica. Na grande maioria das vezes, não passam de meras listas de conteúdos e os planejamentos correspondentes se constituem em uma cópia de índice dos livros didáticos mais adotados. (TERRAZZAN, 1997, p.608)

Diante disso, continua-se, principalmente nos currículos de física e nas aulas de física, priorizando assuntos relacionados à chamada Física Clássica, ou seja, a física correspondente aos séculos XVII à XIX, onde foram desenvolvidas as bases da Mecânica, Termodinâmica e Eletromagnetismo.

Essa tríade de conhecimentos é amplamente encontrada nos índices dos livros didáticos de física, que também privilegiam tais conteúdos, afinal eles já estão enraizados em nosso currículo e já se consolidaram como conhecimentos referentes à física a ser ensinada, na forma de atividades ou exercícios, porém uma física pertencente ao passado.

Assim, devemos pensar que muitos dos avanços tecnológicos atuais e discussões que temos nas mais diversas mídias que usualmente conhecemos fazem, muitas vezes, uma menção a conhecimentos que não se encontram inseridos na tríade acima mencionada, pois pertencem a uma física contemporânea, uma física pertencente ao século $\mathrm{XX}$, a chamada física Moderna e Contemporânea.

Dessa forma, devemos considerar e reafirmar a possibilidade de inserção no programa de física de tópicos relacionados à Física Moderna e Contemporânea (abreviadamente conhecida como FMC), uma vez que muitos pesquisadores nas últimas décadas, dentre os quais destacamos Terrazzan (1994), Valadares e Moreira (1998), Pinto e Zanetic (1999), Ostermann e Moreira (2000a e b), Silva (2002), Canato (2003), Ferreira (2004), Brockington (2005) e Siqueira (2006), já se debruçaram e justificaram essa inserção no 
ensino básico brasileiro. Podemos destacar essa justificativa através de Siqueira, que aponta:

A inserção da FMC faz-se necessária, para conceder aos jovens, uma nova possibilidade de leitura da natureza, contrastando com a leitura, a partir da Física Clássica. Aliás, isso pode ser um ponto favorável ao ensino de FMC no E.M., ou seja, através dessa Física, pode-se mostrar uma outra face da natureza, que é desconhecida pelo jovem, tornando-a assim, mais atrativa por não ter sido ainda explorada. Além do mais, ela pode contribuir para uma visão menos linear e acabada da Física, que normalmente é passada aos alunos. (SIQUEIRA, 2006, p. 8)

Outras justificativas para a inserção da FMC serão apresentadas mais adiante. Procuraremos também apresentar uma seqüência didática referente a um tópico da FMC, em particular da Física das Radiações, e a sua avaliação quanto à exeqüibilidade e permanência como saber escolar ${ }^{3}$. Utilizamos a teoria da Transposição Didática de Chevallard (1991) e as suas regras para validação desta seqüência, uma vez que esse referencial teórico já se mostrou adequado a essa análise em outros momentos, como em Brockington (2005) e Siqueira (2006). Além disso, a idéia de marcadores será apresentada como estratégia didática.

\section{1 - Descrição dos capítulos}

Assim, de forma a organizar o corpo do trabalho, optamos pela seguinte ordenação dos capítulos:

- Introdução - Nesse item apresentamos como foi feito o levantamento do corpo teórico do trabalho de pesquisa. Descrevemos pesquisas em Ensino de Física que estavam inseridas no contexto dos objetivos do trabalho relacionados à FMC, os documentos oficiais (LDB, PCNEM e PCNEM+) e alguns referenciais importantes sobre a Física das Radiações.

- Capítulo 1 - Nesse capítulo descrevemos a metodologia usada nas etapas da pesquisa.

\footnotetext{
${ }^{3}$ Termo usado na teoria da Transposição Didática de Chevallard para designar os saberes, saberes estes que serão apresentados no capítulo 2.
} 
- Capítulo 2 - Apresentamos a didatização dos saberes escolares, tratando da teoria da Transposição Didática de Chevallard, caracterizando os saberes escolares e as regras aplicadas a essa teoria que permitiram a análise da seqüência didática proposta.

- Capítulo 3 - Nesse capítulo é apresentado o curso de Física das Radiações, a escolha dos conteúdos e das atividades da seqüência didática proposta.

- Capítulo 4 - São apresentados os dados coletados nas etapas da pesquisa e suas respectivas análises. Nesse capítulo apresentamos a proposta metodológica elaborada sobre a seqüência didática do curso de Física das Radiações, decorrente dos resultados analisados.

- Conclusão - São feitas as considerações finais e algumas recomendações e sugestões.

\section{2 - A necessidade do Ensino da FMC}

Nas últimas décadas muitos professores e pesquisadores já têm apontado a necessidade da inserção da FMC nas aulas de Física e percebe-se que existem pontos em comum em suas pesquisas quanto às dificuldades para ensiná-la. De maneira geral, as principais e mais relevantes dificuldades apontadas por esses professores e pesquisadores são as seguintes (Ostermann e Moreira, 2000a; Machado e Nardi, 2003):

- Falta de tempo para que seja possível a abordagem de tais conceitos, pois há uma pequena carga horária reservada à Física na maior parte das escolas;

- Pressão exercida nas escolas para se ensinar somente assuntos exigidos nos exames de seleção para ingresso nas universidades, cujos programas usualmente não incluem temas de Física Moderna ou deixam de fora vários conceitos;

- Ausência de pré-requisitos dos estudantes para compreender o assunto; 
- Os conceitos de Física Moderna são abstratos e difíceis, gerando dificuldades para o entendimento pleno de docentes e alunos.

Analisando tais fatores, pode ser que os mesmos desempenhem um enorme papel de obstáculo para que essa inserção ocorra, entretanto, os mesmos não aparentam ser um critério único que permita excluir o ensino da FMC na escola média.

O argumento de uma reduzida carga horária disponível para essa disciplina na maioria das escolas, com um número aproximado de duas ou três horas semanais (dependendo da região, diretoria e turno da escola), representa também um problema quando pensamos no ensino de conceitos da Física Clássica, que dificilmente têm seus conteúdos trabalhados de forma integral conforme o programa proposto para o ano letivo. Assim, tal condição demanda a seleção de temas prioritários a serem abordados, que possam abranger noções tanto da Física Clássica, quanto da FMC, em um planejamento integrado.

Outro fator que certamente influencia nas práticas de ensino e seleção dos conteúdos a serem desenvolvidos nas aulas de física seria a forte influência dos processos seletivos, como os vestibulares, uma vez que estes conseguem estabelecer padrões a serem seguidos e que, supostamente, acabam dando resultados positivos, contribuindo para a aprovação de muitos estudantes nos exames de seleção, mas nem sempre comprometidos com sua formação, os quais acabam apenas sendo doutrinados durante certo período à realização de avaliações. Isso poderia ser contrabalanceado ao se refletir sobre os ganhos em qualidade da educação oferecida aos estudantes quando se incluem assuntos que contribuem para o entendimento de questões atuais e relevantes do cotidiano dos estudantes.

Quanto à falta de pré-requisitos dos estudantes, esta não pode ser considerada um argumento satisfatório para não se abordar a FMC nas escolas, pois existe a concepção de que os alunos alcançam o preparo necessário para compreendê-la somente quando já estudaram detalhadamente os aspectos e conceitos presentes na Física Clássica. Porém, mediante um planejamento apropriado do ensino, é possível concentrar-se no desenvolvimento de idéias essenciais para a apreensão dos conceitos da FMC que se quer trabalhar, e isso não implica percorrer completamente o 
conhecimento gerado anteriormente, com todos os seus detalhes, questionamentos e problemas associados.

Também não é plausível a afirmação de que os conceitos de FMC são abstratos e de difícil compreensão, sendo este um critério muito usado para não os ensinar. Analisando os tópicos presentes na Física Clássica, certamente podemos constatar que ela pode ser tão complexa, ou mesmo abstrata, quanto os tópicos presentes na FMC. Podemos citar como exemplo o conceito de campo, uma idéia fundamental e muito empregada no eletromagnetismo e que apresenta uma complexidade quanto a sua representação e conceituação, quando se discute se ele é criado pela carga ou se ele é um ente indissociável da carga.

Observamos que tanto no ensino das idéias clássicas quanto das modernas, uma questão central é trabalhar na transposição didática de modo a permitir aos estudantes a construção do significado dos conceitos mais importantes e algumas de suas implicações, levando em conta suas atuais condições de desenvolvimento cognitivo, incluindo seu conhecimento matemático, e também os propósitos educacionais a serem atendidos.

Percebemos, entretanto, que outras pesquisas não se limitam apenas em apontar as dificuldades na inserção da FMC, mas também evidenciam a possibilidade de se ensinar satisfatoriamente conceitos dessa área, como sugerem, por exemplo, Ostermann e Moreira (2000b), Brockington (2005) e Siqueira (2006), em estudo relativo à abordagem, respectivamente, dos temas sobre Supercondutividade, Dualidade Onda-Partícula e Física das Partículas Elementares em sala de aula, envolvendo a elaboração de materiais didáticos, que concluíram ser viável o ensino da FMC na escola de nível médio. Em suas investigações, estes pesquisadores consideram de forma geral que:

- Tópicos de FMC despertam a curiosidade científica dos estudantes, melhorando suas atitudes frente à ciência e contribuindo para aumentar sua auto-estima;

- Dificuldades de aprendizagem de temas da FMC não são tão diferentes das usualmente enfrentadas com conteúdos de Física Clássica, embora muitas vezes seja preciso abordar determinados conceitos clássicos antes de expor temas mais recentes, visando a 
proporcionar uma adequação dos conteúdos ao nível dos estudantes para a aprendizagem subseqüente;

- Estudantes podem aprender conceitos de FMC se a forma de apresentação for adequada ao nível em que se encontram.

Assim, podemos verificar que há muitos anos já vem sendo discutida por parte de professores e pesquisadores a importância de se abordar com prioridade alguns tópicos de FMC no Ensino Médio, suas dificuldades e relevâncias.

Pensando em inovação curricular em física, um outro aspecto que vem justificar a atualização do currículo e a inserção de tópicos de FMC é que, se olharmos os conteúdos de biologia e química no Ensino Médio, observam-se tópicos modernos dessas áreas. Analisando de uma forma geral os livros dessas disciplinas, podemos ver assuntos que tratam de células tronco, genoma, DNA, níveis de energia, spin dos elétrons, entre outros assuntos.

Todos esses conteúdos fazem parte de uma Ciência Moderna, desenvolvida no século $X X$ e que já se encontram em sala de aula, nas discussões que ocorrem nas disciplinas citadas anteriormente, mas infelizmente vemos ainda de uma maneira muito modesta e tímida tópicos ligados a física desse século nas discussões feitas no Ensino Médio, como aponta Valadares e Moreira:

Em nosso cotidiano deparamos cada vez mais com novos aparelhos eletrônicos e opto-eletrônicos, dispositivos automáticos, sistemas de controle, novos usos do laser em medicina e nas telecomunicações, além de aplicações em várias áreas industriais. Tudo isso e muito mais está presente em casa, nas lojas, nos hospitais, supermercados, carros, aeroportos e por que não, também nas próprias escolas. (VALADARES e MOREIRA, 1998, p.121)

Pode-se indagar ainda que conhecer o princípio de funcionamento dos diversos equipamentos modernos não faz alguém viver melhor. Essa é uma falsa impressão, pois ao conhecer esses princípios através da FMC o sujeito poderá entender melhor os riscos e perigos que pode correr ao utilizar esses equipamentos de forma errada, e, além disso, poderá ser inserido em uma discussão mais ampla, sabendo expor suas opiniões e recebendo as informações de forma crítica. 
Diante disso, podemos notar que a atualização curricular é necessária para que o indivíduo possa interagir com o mundo em que vive, isto é, a atualização do currículo de física é justificada pela maior inserção dos jovens ao conhecimento do mundo a sua volta, como destacam Valadares e Moreira:

É imprescindível que o estudante do Ensino Médio conheça os fundamentos da tecnologia atual, já que atua diretamente em sua vida e certamente definirá o seu futuro profissional. Daí a importância de se introduzir conceitos básicos da Física Moderna e, em especial, de se fazer uma ponte entre a Física da sala de aula e a Física do cotidiano. (VALADARES e MOREIRA, 1998, p.121)

Mas a defesa da inserção da FMC no Ensino Médio não se restringe a esses argumentos. Outros pesquisadores, afirmam que ela pode contribuir para uma visão mais apropriada da ciência:

Acreditamos que o ensino de Física Moderna e Contemporânea a alunos secundaristas se reveste de grande importância, uma vez que a introdução de conceitos atuais de Física pode contribuir para dar uma imagem mais correta desta ciência e da própria natureza do trabalho científico. (GIL et al., 1987, p.209)

É comum encontrarmos jovens que acreditam que a física é algo feito por pessoas iluminadas e providas de altíssima inteligência, verdadeiros gênios, sendo elas levadas a criar um estereótipo do pesquisador, do professor e do estudante de física, como pessoas quase ou totalmente alienadas, porém muito inteligentes, que parecem vir de outro mundo, um mundo muito diferente daquele em que elas vivem.

Acreditamos que a inserção de tópicos de FMC possa contribuir para a revisão dessa representação, mostrando que a física é construída por pessoas comuns, que dedicam muito tempo de suas vidas, tentando responder às questões que intrigam a humanidade. Dessa forma, espera-se que o jovem possa estreitar seus laços com a física, procurando conhecê-la mesmo que não venha a seguir uma carreira que a utilize diretamente, mas que o permita entender melhor o mundo que o cerca.

Diante dessa argumentação sobre a inserção da FMC, podemos destacar uma outra, que talvez possa ser mais atrativa e cativante para o aluno: ao conhecer um pouco mais da FMC, o jovem poderá acessar o mundo com um outro olhar, como aponta Brockington: 
Como o Ensino Médio passa a ser a única forma de escolarização formal em Física, ao não se tratar de FMC priva-se o futuro cidadão, em face de tudo que foi discutido anteriormente, de tomar conhecimento desta nova maneira, criada pelo homem, de compreender e prospectar a realidade. (BROCKINGTON, 2005, p. 15)

A inserção da FMC é necessária para conceder aos jovens uma nova possibilidade de leitura da natureza, contrastando com a visão obtida a partir da Física Clássica. Aliás, isso pode ser um ponto favorável ao ensino de FMC no nível médio, ou seja, através dessa física, pode-se mostrar uma outra face da natureza, que é desconhecida pelo jovem, tornando-a, assim, mais atrativa por não ter sido ainda explorada. Além do mais, ela pode contribuir para uma visão menos linear e acabada da física, que normalmente é passada aos alunos, além de possibilitar uma nova visão e releitura da própria Física Clássica.

Portanto, não é necessário excluir os conteúdos já encontrados na sala de aula, mas procurar modernizá-los, ou seja, apresentar o conteúdo sob um ponto de vista mais moderno. Contudo, deve-se tomar cuidado para que esse novo conteúdo não seja ensinado de maneira tradicional. Assim, acreditamos que novos conteúdos, como tópicos de FMC, necessitam de abordagens e metodologias diferentes para o seu aprendizado, além de materiais e atividades a serem construídos.

A falta de material para professores é um aspecto do problema que começa a ser enfrentado, principalmente através de iniciativas de pesquisadores que tentam divulgar a FMC em uma linguagem mais adequada. No entanto, esse material não se encontra adequado para sala de aula, ou seja, ainda não há material que possa ser diretamente aplicado pelo professor, como, por exemplo, um livro didático satisfatório.

Já a formação do professor se torna um aspecto de suma importância, pois como podemos pensar na inserção da FMC se não temos profissionais formados adequadamente para isso? Em sua maioria, os cursos de licenciatura em física têm poucas disciplinas que abordam tópicos de FMC, e ainda são mais raros os cursos de formação continuada que visam a trabalhar esses tópicos. Porém, para que o professor possa ministrar um curso de FMC no Ensino Médio, é necessário que ele saiba não somente o conteúdo, mas 
também como aplicá-lo, pois exige uma abordagem diferente da tradicional. Tais obstáculos podem ser superados com propostas bem estruturadas e com a consciência das dificuldades que poderiam ser encontradas (SIQUEIRA e PIETROCOLA, 2006).

Percebemos então que não basta fornecer material didático aos professores. É preciso investir em formação, mesmo porque não podemos inserir a FMC nos moldes tradicionais da Física Clássica, pois assim, corre-se o risco de se ter somente mais conteúdos no currículo, sem proporcionar aos alunos a chance de reconhecer as diferenças existentes entre a Física Clássica e a Moderna.

\section{3 - Qual tema escolher?}

A justificativa para a escolha do tema desta pesquisa pode ser feita em dois momentos. Um primeiro momento baseando-se na legislação vigente, nos documentos oficiais para a Educação Básica e o ensino de física no Ensino Médio, e nas pesquisas relatadas anteriormente. Em um segundo momento, através das discussões que o tema permite proporcionar acerca das idéias e conceitos presentes na FMC em nossa vida cotidiana, e que muitas vezes passam despercebidos aos nossos olhares, mas que são de fundamental importância para o entendimento dos objetos que nos rodeiam, como por exemplo, a luz.

Inicialmente, fazendo-se uma análise dos textos da Lei de Diretrizes e Bases da Educação Nacional (BRASIL, 1996), dos Parâmetros Curriculares Nacionais (BRASIL, 1999) e, mais recentemente, das Orientações Curriculares Nacionais Complementares aos Parâmetros Curriculares Nacionais para o Ensino Médio (BRASIL, 2002), observamos o apontamento de características que devem ser encontradas no "Novo Ensino Médio", como a seguinte:

Propõe-se, no nível do Ensino Médio, a formação geral, em oposição à formação específica; 0 desenvolvimento de capacidades de pesquisar, buscar informações, analisá-las e selecioná-las; a capacidade de aprender, criar, formular, ao invés do simples exercício de memorização. (BRASIL, 1999, p.5) 
Com relação ao ensino de física, os documentos indicam que a escolha dos temas a serem abordados deve ser feita de modo que o conhecimento de física deixe de se estruturar em um objeto em si mesmo, e passe a ser entendido como um instrumento para a compreensão do mundo. Eles ainda assinalam que os conhecimentos de física são fundamentais para a formação científica do cidadão contemporâneo e que o estudo dos conceitos físicos deve ser contextualizado e interagir com outras disciplinas de forma a ganhar sentido quando aplicado ao dia a dia de jovens e adolescentes. Apontam também para o fato de que alguns aspectos da chamada Física Moderna são indispensáveis para permitir aos alunos adquirir uma compreensão mais abrangente dos conhecimentos físicos necessários para o entendimento das tecnologias mais recentes.

Além disso, o estudo da física deve ser compreendido pelo aluno como um processo de construção humana, inserido num contexto histórico e social, abrangendo um corpo teórico de conhecimentos científicos e tecnológicos que têm contribuído para o desenvolvimento de pesquisas que podem melhorar a qualidade de vida da sociedade.

Assim, habilidades e competências precisam ser construídas no ensino de física de forma a dar significados aos conhecimentos adquiridos e "(...) os critérios que orientam a ação pedagógica deixam, portanto, de tomar como referência primeira o que ensinar de Física, passando a centrar-se sobre o para que ensinar Física (...)" (BRASIL, 2002, p.78), visando a uma formação científica mais crítica.

Com relação ao que o documento chama de "Temas Estruturadores", onde seis deles foram privilegiados para organizar de forma mais abrangente $o$ ensino de física, interessou-nos, mais particularmente, o tema "Matéria e Radiação". Como justificativa para a escolha desse tema, ressaltamos a importância do estudo das radiações e suas interações com a matéria, tomando como base os modelos de constituição da matéria e o espectro eletromagnético, proporcionando uma abordagem e compreensão dos fenômenos associados a essas interações e ampliando, dessa maneira, o entendimento do universo físico microscópico. Conforme os PCNEM+: 
(...) o cotidiano contemporâneo depende, cada vez mais intensamente, de tecnologias baseadas na utilização de radiações (...). Introduzir esses assuntos no ensino médio significa promover nos jovens competências para, por exemplo, ter condições de avaliar riscos e benefícios que decorrem da utilização de diferentes radiações, compreender os recursos de diagnóstico médico (radiografias, tomografias, etc.) (...) (BRASIL, 2002, p.77)

$\mathrm{Na}$ sugestão das unidades temáticas relacionadas ao tema Matéria e Radiação, gostaríamos de ressaltar a unidade temática Radiações e suas Interações, onde parte do conteúdo programático está presente em nossa proposta do curso de Física das Radiações ${ }^{4}$. O potencial desse tema é evidenciado pelos PCNEM+:

Identificar diferentes tipos de radiações presentes na vida cotidiana, reconhecendo sua sistematização no espectro eletromagnético (das ondas de rádio aos raios gama) e sua utilização através de tecnologias a elas associadas (radar, rádio, forno de microondas, tomografia etc.) [...] Compreender os processos de interação das radiações com os meios materiais para explicar os fenômenos envolvidos em, por exemplo, fotocélulas, emissão e transmissão de luz, telas de monitores, radiografias. (BRASIL, 2002, p.78)

Assim, apoiados nas pesquisas anteriores em Ensino de Física mencionadas, nos documentos oficiais e na lista de tópicos eleitos como mais importantes na pesquisa de Ostermann \& Moreira (1998 apud Ostermann; Moreira, 2000a), escolhemos a "Física das Radiações" como tópico de FMC para a proposta que foi elaborada.

A opção por esse tópico justifica-se pelo fato de que o seu estudo permite uma abordagem sobre FMC através de assuntos como os modelos atômicos, o espectro eletromagnético, as radiações ionizantes e suas aplicações, além de outras.

Devido à abrangência do assunto, pode-se também relacionar a física com outras áreas do conhecimento, como a história, através da compreensão do momento histórico em que se deu a divulgação científica de Röntgen, por exemplo, influenciando rapidamente os diagnósticos na medicina, e a própria biologia, através dos efeitos nocivos da exposição excessiva das células aos raios-X.

Convém também ressaltar que analisando, por exemplo, uma radiação eletromagnética como a luz, dentro de uma proposta de estudo das formas de

\footnotetext{
${ }^{4}$ Será oportunamente apresentado no capítulo 3 da dissertação.
} 
radiação (corpuscular e eletromagnética), desde sua forma de produção, interação com a matéria, histórico de estudo e pesquisa realizada por diversos cientistas que se maravilharam com essa forma ímpar de energia e de caráter dualístico, pode-se evidenciar a sua importância para a existência da vida e de tudo mais que existe em nosso Universo, possibilitando um maior entendimento de seu funcionamento, leis que o regem e de sua própria criação.

Desde a época de Isaac Newton (1642-1727) e suas idéias sobre os corpúsculos de luz até a época de Albert Einstein (1879-1955) e seus fótons de luz, a luz e sua natureza passou por diversos questionamentos que serviram para promover avanços inquestionáveis na forma como vemos e enxergamos o mundo. Nas teorias físicas, o seu estudo permitiu debates inesquecíveis como o da teoria corpuscular versus a teoria ondulatória, sem citarmos a quantização da energia e os fótons de luz, que elucidaram a problemática presente no efeito fotoelétrico descoberto por Hertz.

Assim, a luz como uma forma de radiação, esteve e continua presente até hoje em muitas pesquisas, possibilitando desde a compreensão de fenômenos até inovações em equipamentos, como um melhor entendimento do funcionamento do olho humano, explicação das cores do arco-íris, criação e aperfeiçoamento de dispositivos como os telescópios, microscópios, câmeras e óculos, novos produtos como o laser, fibra óptica, hologramas, computadores, imagens médicas, além de questionamentos e a busca por novas respostas, ou mesmo, reformulação daquelas que aparentemente já foram respondidas. Portanto, por que não utilizar as radiações, suas formas de manifestação e sua interação com a matéria para a inserção de tópicos da FMC no Ensino Médio?

Conforme já relatado anteriormente, as propostas para a inserção da FMC são bastante tímidas e em pequena escala. Quanto à proposta da Física das Radiações como tema para as aulas de física, essa porcentagem diminui ainda mais, o que pode ser facilmente constatado em uma revisão bibliográfica sobre o tema, onde autores como Ostermann e Moreira (2000c), Silva (2002), Canato (2003), Ferreira (2004) e Oliveira (2006), assinalam a ausência desse tema e a importância de sua inserção nos currículos de física na escola média. Dessa forma, e diante de todas as colocações aqui apresentadas, é que se propõem como tema para inserção de tópicos da FMC a Física das Radiações. 


\section{4 - Por que a Transposição Didática?}

A escola, dentre suas principais funções, tem o papel da transmissão de conhecimentos produzidos pela humanidade. Particularmente os conhecimentos científicos, na medida em que são elaborados, passam por processos de codificação, sendo que os processos didáticos devem considerar os códigos científicos. Contudo, tais códigos passam por uma decodificação ou transposição para ser apreendida pelos alunos.

Para ocorrer a transmissão ou comunicação, é necessário que o conhecimento seja transformado. $O$ processo de transformação do conhecimento coloca diversas problemáticas, dentre elas, a diferença entre os elementos do conhecimento produzido e do conhecimento a ser aprendido (ALVES-FILHO, 2000a) estabelecendo uma ruptura entre o conhecimento trabalhado na escola e aquele produzido originalmente.

Um grande desafio do professor é transformar um conhecimento científico em um conteúdo didático. De fato, teorias complexas, sem perder suas propriedades e características, precisam ser transformadas para serem compreendidas pelos alunos. Assim, a Transposição Didática pode ser concebida como um conjunto de ações transformadoras que tornam um saber sábio em saber ensinável:

No ambiente escolar, o ensino do saber sábio se apresenta no formato do que se denomina de conteúdo ou conhecimento científico escolar. Este conteúdo escolar não é o saber sábio original, ele não é ensinado no formato original publicado pelo cientista, como também não é uma mera simplificação deste. $O$ conteúdo escolar é um "objeto didático" produto de um conjunto de transformações. [...]. Após ser submetido ao processo transformador da transposição didática, o "saber sábio" regido agora por outro estatuto, passa a constituir o "saber a ensinar". (ALVES-FILHO, 2000a, p. 219)

O saber a ensinar é aquele entendido como conteúdo escolar ou como programa escolar. Este autor entende que existe uma segunda transposição didática, ou seja, o conteúdo presente nos livros e materiais didáticos ao serem ensinados também são transformados. Conforme Alves-Filho (2000b), o saber científico foi desenvolvido e publicado ao longo de muitos anos por muitos personagens. Passou pela crítica, reformulações, aceitações e legitimação de outros cientistas. 
Pensando sobre a Física das Radiações e tomando-a como exemplo de saber sábio, podemos afirmar que o início de sua história ocorre no inverno de 1895, com a descoberta experimental dos raios-X por Wilhelm Konrad Röntgen (1845-1923), professor de Física da Universidade de Würzburg na Alemanha. Analisando esse episódio histórico e considerando-o como um saber sábio que já foi transposto para os livros didáticos, percebemos que muitos de seus aspectos históricos, motivações e preocupações da época, conseqüências de sua descoberta e uso, podem ser analisados de acordo com o referencial teórico da Transposição Didática de Chevallard (1991), possibilitando afirmar a diferença entre o saber produzido pelos cientistas e o saber que está escrito nos textos escolares.

Afinal, o saber escolar é produzido na confluência entre o objeto a ser ensinado, que tem um perfil epistemológico definido e independente, um projeto político-pedagógico (explicitado ou não, democraticamente construído ou não) que estabelece conhecimentos, valores e atitudes relevantes, e um conjunto de procedimentos didáticos que deverão tornar o objeto de saber um objeto ensinável.

É necessário, portanto, um cuidado muito grande para que durante o processo de transposição do saber sábio para o saber a ser ensinado, o conhecimento de referência não seja distorcido a ponto de se tornar irreconhecível. Chevallard (1991, p. 49) chama de vigilância epistemológica a preocupação que se deve ter com a correspondência entre os dois saberes.

A quebra de correspondência é freqüentemente operada pelos livros didáticos que afastam os conceitos científicos das suas redes conceituais históricas, ocultando, assim, os problemas originais dos cientistas (ASTOLFI e DEVELAY, 2002, p.48) e enquadrando o saber sábio numa moldura empíricomatemática supostamente neutra.

Além de empobrecer o sentido da física, a descontextualização ${ }^{5}$ possui um efeito direto sobre a significação específica do conteúdo a que está relacionada. Afinal, um conhecimento descontextualizado de modo dogmático é aquele que foi separado dos outros conceitos e problemas com que se

\footnotetext{
${ }^{5}$ Termo usado na teoria da Transposição Didática de Chevallard (1991) que será apresentado no capítulo 2.
} 
relacionava e isolado numa configuração escolar que artificializa problemas e redes conceituais.

Diante disso, na elaboração da seqüência didática do curso de Física das Radiações e ciente das preocupações apontadas anteriormente, optamos pela utilização da teoria da Transposição Didática e suas regras para além da validação desta seqüência, a fim de mantermos a vigilância epistemológica durante o trabalho e evitar que recaíssemos sobre os mesmos erros apontados nos materiais didáticos que atualmente estão disponíveis, mesmo em quantidade pequena, para a inserção da FMC a respeito deste tópico no Ensino Médio. 


\section{CAPÍTULO 1}

\section{A METODOLOGIA DA PESQUISA}

\section{1 - Introdução}

No desenvolvimento deste trabalho, uma das questões abordadas referese à atualização curricular, questão que merece uma posição de destaque dentro das pesquisas que se realizam no ensino de física. Entretanto, grande parte das pesquisas que se propõem a fazer essa discussão, limitam-se a apresentar as necessidades dessa atualização ou, simplesmente, justificam se essa atualização é possível ou não de ser realizada. Diante disso, procuramos focar nossa atenção a um outro nível dessa discussão, apresentando elementos que permitam mostrar como fazer essa atualização.

Para mostrar como é possível fazer essa atualização, foi elaborada uma proposta de uma seqüência didática de um curso de Física das Radiações para alunos do Ensino Médio, onde se buscou trazer elementos dessa área da FMC para as discussões em sala de aula. Entretanto, como ensinar a Física das Radiações para alunos do Ensino Médio? Como garantir que esta seqüência didática seja exeqüível?

Questionamentos como esses são difíceis de serem respondidos em virtude da complexidade do processo de ensino-aprendizagem, porém, para auxiliar a análise da seqüência didática utilizamos a teoria da Transposição Didática e sua regras que se mostram adequadas para a análise pretendida. Entretanto, ainda é necessário em uma pesquisa confrontar os dados, as evidências, as informações coletadas sobre 0 assunto e o conhecimento teórico a respeito dele. Logo, é necessária a escolha de uma metodologia de pesquisa. A seguir, apresentamos os critérios utilizados para a escolha da metodologia empregada nesta pesquisa. 


\section{2 - A escolha da metodologia da pesquisa}

Em educação a escolha de uma metodologia de pesquisa é algo bastante complexo, afinal, existem muitas variáveis atuando ao mesmo tempo. $\mathrm{Na}$ própria literatura não existe um consenso quanto à melhor metodologia para estudar os fenômenos educacionais, como aponta Gonçalves:

Já que não existe uma única metodologia de pesquisa adequada ao estudo da gama dos fenômenos educacionais, é natural que cada investigador realize seu esforço pessoal na busca de uma forma de pesquisar que seja adequada ao seu objeto de estudo e às suas próprias convicções, à sua visão de Ciências e até mesmo à sua formação acadêmica. (GONÇALVES, 1997, p. 105)

Assim, considerando-se a proposta deste trabalho em analisar uma seqüência didática de um curso de Física das Radiações para alunos do Ensino Médio, optamos pela pesquisa qualitativa, não porque esta seja melhor, mas porque acreditamos ser a forma de investigação que possa trazer mais significado à pergunta inicial, a fim de que ao término deste estudo, consigamos extrair dados suficientes para analisar 0 processo no qual 0 conhecimento se estabelece em sala de aula, analisando-os à luz da teoria da Transposição Didática, teoria esta que já mostrou ser capaz de lidar com a sobrevivência dos saberes escolares em sala de aula (ALVES-FILHO, 2000b; RODRIGUES, 2001; BROCKINGTON, 2005; SIQUEIRA, 2006).

Outros argumentos favoráveis ao uso de uma abordagem qualitativa nesta pesquisa podem ser evidenciados nos estudos de Lüdke e André (1986) que ressaltam a importância dessa forma de pesquisa em educação. Além disso, conforme Bogdan e Biklen (1982), a pesquisa qualitativa se define de acordo com cinco características básicas:

- A pesquisa qualitativa tem o ambiente natural como sua fonte direta de dados e o pesquisador como seu principal instrumento;

- Os dados coletados são predominantemente descritivos;

- A preocupação com o processo é muito maior do que com o produto;

- O significado que as pessoas dão às coisas e à sua vida são focos de atenção especial do pesquisador; 
- A análise dos dados tende a seguir um processo indutivo.

Analisando as características e os tipos de pesquisa qualitativa existentes, esta pesquisa se classifica como um estudo de caso. Uma primeira constatação desse fato pode ser vista em Triviños (1987) que aponta o estudo de caso como "uma categoria de pesquisa cujo objeto é uma unidade que se analisa aprofundadamente" (TRIVIÑOS, 1987, p. 133). Além disso, quando falamos de estudo de caso, estamos nos reportando a um tipo de estudo muito empregado nas Ciências Sociais que, como Ludke e André (1986) afirmam:

O estudo de caso é o estudo de um caso, seja ele simples e específico, como o de uma professora competente de uma escola pública, ou complexo e abstrato, como das classes de alfabetização (CA) ou do ensino noturno. O caso é sempre bem delimitado, devendo ter seus contornos claramente definidos no desenrolar do estudo. (LUDKE e ANDRÉ, 1986, p. 17)

Ainda, de acordo com Ludke e André (1986), todo estudo de caso tem um caráter qualitativo, visto que se desenvolve em uma situação natural e é composto por dados descritivos. Também se caracteriza por ser aberto e flexível e focalizar uma determinada situação de forma complexa e contextualizada.

Assim, o estudo de caso pode ser caracterizado como um estudo de uma entidade bem definida, como um programa, uma instituição, um sistema educativo, uma pessoa ou uma unidade social. Esse estudo visa a conhecer o seu "como" e os seus "porquês", evidenciando a sua unidade e identidade próprias. É uma investigação que assume um caráter bastante particular, debruçando-se sobre uma situação específica, procurando descobrir o que há nela de mais essencial e característico. Entretanto, Martins (2006) identifica os predicados que o estudo de caso deve possuir para que ele seja merecedor de tal atenção, apontando que:

(...) é necessário que o que o pesquisador busca pesquisar utilizando-se dessa metodologia, seja importante. Isso se dá quando é "original e revelador, eficaz, suficiente e relatado de maneira atraente". (MARTINS, 2006, p. 2)

Como um dos objetivos deste trabalho é o de analisar uma seqüência didática inovadora, pertencente a uma área da FMC que possui uma tímida quantidade de materiais que abordem o tema da Física das Radiações para o 
Ensino Médio, o estudo de caso corresponde a uma forma de pesquisa que pode contribuir para a análise desse material, trazendo à tona elementos que permitam verificar a sua exeqüibilidade nas aulas de Física do Ensino Médio, enquanto seqüência didática, pois o estudo de caso, conforme apontado anteriormente, tem sempre um forte cunho descritivo, de onde podem ser retirados elementos para análise.

Nesse processo, o pesquisador não pretende intervir sobre a situação, mas conhecê-la tal como ela Ihe surge. Para tanto, pode valer-se de uma grande variedade de instrumentos e estratégias. No entanto, um estudo de caso não tem que ser unicamente descritivo. Pode confrontar a situação com outras já conhecidas e com as teorias existentes. Pode ajudar a gerar novas teorias e novas questões para futura investigação. Assim, de uma forma geral, as principais características encontradas nessa forma de pesquisa qualitativa apontadas por Ludke \& André (1986, p. 20) são as de que esse estudo:

- visa a descoberta (o quadro teórico inicial serve de base para novos aspectos e dimensões que poderão aparecer a medida que o estudo avance);

- enfatiza a interpretação em contexto (para uma apreensão mais completa do objeto, é preciso levar em conta o contexto em que ele se situa);

- busca retratar a realidade de forma completa e profunda (procura-se revelar a multiplicidade de dimensões presentes numa determinada situação ou problema, focalizando-o como um todo);

- revela experiências vividas (que permitem generalizações naturalísticas, aplicação a outras situações similares e associação dos resultados com outras experiências);

- procura representar os diferentes e, às vezes, conflitantes pontos de vista presentes numa situação social (pressupõem-se que a realidade pode ser vista sob diferentes perspectivas);

- utiliza uma linguagem e uma forma mais acessível do que os outros relatório de pesquisa (relatos informais, narrativos, ilustrativos; uso de desenhos, fotografias, colagens, dramatizações). 
Finalmente, diante desse cenário e através das constatações encontradas na literatura, a pesquisa realizada neste trabalho se classificou como qualitativa e do tipo estudo de caso e, portanto, seguiu para uma das etapas mais importantes em qualquer forma de pesquisa, a da coleta de dados. A seguir, descrevemos como foi feita essa coleta de dados e quais os instrumentos utilizados para sua realização.

\section{3 - A coleta de dados ${ }^{1}$ e a técnica da triangulação}

Existem várias formas de coletar dados de pesquisa, e isso ocorre porque há muitas possibilidades quanto aos próprios instrumentos de pesquisa. $\mathrm{A}$ escolha do instrumento é de competência do pesquisador e deve ser levado em conta o tipo de estudo e os objetivos pretendidos. Qualquer que seja o instrumento a ser utilizado, deve ser bem elaborado e bem dimensionado para que o resultado esperado seja alcançado.

Assim, o processo de coleta de dados em uma pesquisa qualitativa pode envolver diversas técnicas, como a observação, entrevistas, discussões em grupo focais, uso de fotografias, gravação em vídeo, entre outras. Todavia, qualquer que seja o processo de coleta de dados, em geral, as pesquisas qualitativas geram enorme quantidade de informações que precisam ser organizadas.

A idéia básica é identificar categorias, padrões e relações entre os dados coletados, de forma a desvendar seu significado por meio da interpretação e da comparação dos resultados com outras pesquisas e referenciais teóricos.

Pensando na seqüência didática sobre Física das Radiações, o que pretendemos responder e analisar sob à luz da Transposição Didática, é se seria possível ensinar esse tema da Física para alunos do Ensino Médio. Portanto, optamos por fazer a tomada de dados de diversas maneiras,

\footnotetext{
${ }^{1}$ Em seu livro, Trivinõs (1987, p. 141) procura fazer uma distinção entre os termos "dados" e "materiais", termos estes empregados em uma pesquisa qualitativa, e aponta que o autor Lofland (1971) sugere que os pesquisadores qualitativos deveriam usar "materiais" ao invés de "dados", pois para ele o último termo está carregado de conotações positivistas. Assim, "dado" seria o que pode ser medido, quantificado, enquanto a palavra "materiais" seria mais ampla, menos comprometida com a quantificação e serviria, assim, melhor aos objetivos e características da pesquisa qualitativa. Neste trabalho, usaremos indistintamente "dados" e "materiais" para nos referirmos a todo tipo de informações que o pesquisador reúne e analisa para estudar determinado fenômeno.
} 
acreditando que, com isso, conseguiríamos um número suficiente de informações para a análise a ser realizada posteriormente.

Utilizamos três instrumentos para a obtenção dos dados: a gravação em vídeo, análise de documentos (produção dos alunos) e uso de questionários, assumindo que quando uma dessas técnicas não forneça os dados de maneira adequada, as outras possam desempenhar este papel de uma forma mais satisfatória.

A escolha dos instrumentos de coleta de dados nesta pesquisa qualitativa foi baseada na técnica da triangulação de dados, descrita da seguinte forma por Triviños:

A técnica da triangulação dos dados tem por objetivo básico abranger a máxima amplitude na descrição, explicação e compreensão do foco em estudo. Parte de princípios que sustentam que é impossível conceber a existência isolada de um fenômeno social, sem raízes históricas, sem significados culturais e sem vinculações estreitas e essenciais com uma macrorrealidade social. (TRIVIÑOS, 1987, p. 138)

Portanto, utilizando-se da técnica da triangulação na coleta de dados, que apresenta os elementos que serão utilizados pelo pesquisador em sua pesquisa, é feita uma tentativa de se minimizar as possíveis interferências dentro do processo de investigação, não se esquecendo que neste trabalho o foco encontra-se nos saberes e na forma como estes se estabelecem na sala de aula, a partir das adaptações e transformações que ele sofre, enfatizando o emprego da Transposição Didática como uma ferramenta de análise das transformações que os saberes sofreram até se estabelecerem no ambiente escolar. Entretanto, o aspecto da aprendizagem em nenhum momento foi deixado de lado, pois ele é intrínseco ao processo de ensino, e embora não seja o aspecto de estudo deste trabalho, foi fundamental e norteador de nossas preocupações durante a criação da proposta. Assim, a análise foi feita exclusivamente sobre a seqüência didática elaborada para o curso de Física das Radiações. 


\subsection{1 - Descrição dos instrumentos de coleta de dados}

A seguir, iremos descrever os instrumentos usados na coleta de dados, bem como as características e objetivos pretendidos com cada um desses.

\section{- Gravação em vídeo}

Esse foi o primeiro instrumento usado para a coleta de dados. As gravações preocuparam-se não somente com o registro eficiente das imagens em vídeo, mas também teve-se uma preocupação com o registro do áudio, de forma que as falas dos alunos durante as aulas possibilitassem futuramente a sua inclusão na análise das atividades e discussões realizadas.

Esse tipo de coleta de dados foi feito visando a captação das imagens dos alunos em contato com o material produzido na seqüência didática, as atividades e o próprio conteúdo apresentado durante as aulas, buscando, dessa forma, captar as impressões deles durante as discussões, o levantamento de hipóteses na realização das atividades e as dificuldades encontradas no contato com os novos conceitos e a sua inserção. Assim, pudemos obter um material mais rico para a elaboração das conclusões sobre o curso, além de serem mais fiéis ao que ocorreu de fato no ambiente escolar.

As gravações foram realizadas em dois ambientes distintos do colégio: no laboratório da escola e na própria sala de aula. Isso ocorreu devido a uma opção do professor aplicador ${ }^{2}$, conforme o dia da gravação da aula e melhores condições para se fazer o seu registro, não por que fosse exigido um local como o laboratório para a execução das atividades. No local de gravação, fosse ele o laboratório ou a sala de aula, a câmera permanecia em um ponto da sala, não fixo, de forma a captar todos os alunos, e em algumas situações, também o professor. O responsável pelas gravações foi um estagiário, aluno concluinte do curso de Licenciatura em Física Diurno do IFUSP e estagiário, devidamente orientado pelo professor aplicador, não tendo nenhuma participação nas discussões e atividades realizadas durante as aulas.

\footnotetext{
${ }^{2}$ O professor aplicador da proposta do curso de Física das Radiações foi um professor da rede estadual de ensino, efetivo no cargo de Física e membro pertencente ao grupo do Laboratório de Pesquisa e Ensino de Física (LAPEF). A opção de sua escolha como aplicador será explicitada mais adiante.
} 


\section{- Análise de documentos}

Quando nos referimos a análise de documentos estamos nos referindo à produção dos alunos. Dessa forma, utilizamos os trabalhos escritos pelos alunos individualmente ou em grupo, bem como as avaliações e exercícios realizados por eles.

Com esse instrumento dispomos de um material que pode servir de forma a rever as conclusões que foram elaboradas pelos alunos nos momentos de discussão que aconteceram no desenvolvimento do curso, bem como as hipóteses levantadas por eles na resolução das atividades e exercícios, revelando a maneira como pensaram e estruturaram os conceitos apresentados.

\section{- Questionário}

O uso do questionário foi um dos instrumentos escolhidos por permitir ao pesquisador explicar os objetivos do estudo e tirar as dúvidas do informante, além de os dados coletados estarem mais isentos de vícios. Dessa forma, como a intenção do questionário era a de verificar se a seqüência didática proposta poderia se tornar um saber escolar, as questões presentes no questionário ficaram focadas nos textos, atividades, avaliações, exercícios e todo tipo de material utilizado na elaboração e aplicação da seqüência de ensino de Física das Radiações.

Com o questionário buscou-se resgatar também as impressões que os alunos tiveram durante a aplicação do curso, ajudando na compreensão do que eles pensaram sobre o texto, as questões referentes a elas e as atividades.

\subsection{2 - Caracterização do local de aplicação}

O curso foi aplicado na Escola Estadual Professora Heloisa Carneiro, situada na zona sul de São Paulo, no bairro do Jardim Miriam, escola esta pertencente à Diretoria de Ensino Sul 1.

Nessa escola, a proposta do curso foi desenvolvida no período de 2 de outubro de 2007 à 30 de novembro de 2007, em uma turma da terceira série do 
Ensino Médio, denominada de $3^{\circ} \mathrm{G}$, pertencente ao período noturno e modalidade EJA. As aulas aconteceram no decorrer do horário normal, e obedecendo ao calendário escolar vigente do ano letivo, mais precisamente no $2^{\circ}$ bimestre do $2^{\circ}$ semestre. As aulas aconteciam sempre às $3^{\text {as }}$ feiras, no intervalo das $19 \mathrm{~h}$ às 20:30 h, ou seja, em duas aulas consecutivas.

Por acontecer no período noturno e aplicado a alunos da modalidade EJA, as aulas tinham duração de 45 minutos. À noite, a grade curricular da escola tem 5 aulas, totalizando 25 aulas semanais, enquanto o período diurno dispõe de 6 aulas por dia, totalizando 30 aulas semanais. Embora existissem diferenças entre o número de aulas para os alunos do período diurno e do período noturno, essa diferença não se refletiu nas aulas de física, pois em ambos os períodos existiam apenas duas aulas de física por semana para todas as séries do Ensino Médio, seja na modalidade regular ou EJA.

\subsection{3 - Caracterização da turma}

A turma do $3^{\circ} \mathrm{G}$ era formada por 45 alunos na lista piloto, isto é, 45 alunos matriculados com os nomes presentes no diário de classe, dos quais, 35 participaram do curso efetivamente. Era uma turma com um comportamento muito apático e de aprendizagem considerada mediana na avaliação dos professores que lecionavam nessa turma. Essas informações foram fornecidas ao professor aplicador da proposta durante uma conversa na sala dos professores no período do intervalo.

Entretanto, a turma dispunha de alunos que se mobilizavam a trabalhar conforme aquilo que Ihes era dado como atividade. Essa característica, embora importante para a aplicação de um curso com atividades investigativas, como é o curso de Física das Radiações, não foi um fator determinante para a escolha da turma de aplicação do curso, pois os verdadeiros motivos foram os seguintes: ser a única turma que mantinha o número de alunos com melhor regularidade, pois a outra turma de $3^{\circ}$ ano e também da modalidade EJA, tinha alunos que faltavam demais as aulas; a turma escolhida já estava com o professor aplicador da proposta pelo terceiro semestre consecutivo, o que facilitou a aplicação da mesma, devido ao entrosamento e compromisso do 
professor com seus alunos e vice-versa, ou seja, já havia um contrato didático ${ }^{3}$ básico estabelecido.

Quanto à faixa etária dos alunos, esta variava entre os 19 e 51 anos, algo comum nos dias de hoje em uma turma da modalidade EJA. A condição sócioeconômica era praticamente homogênea. Grande parte pertencia à classe baixa, trabalhava durante o dia, exceto as senhoras aposentadas e que cuidavam do lar. Podemos destacar como principal diferencial o contraste das idades e as razões que os motivaram a irem cursar a modalidade EJA, entre as quais ressaltamos a necessidade urgente de obtenção de um certificado de conclusão do Ensino Médio, pois as empresas onde eles trabalhavam estavam exigindo, até a medida da "aceleração" dos estudos de alguns alunos mais jovens que não se adaptaram no regular, de modo que eles concluíssem seus estudos mais rapidamente.

Finalmente, os alunos da turma do $3^{\circ} \mathrm{G}$ foram bem receptivos ao curso e tivemos a impressão de que, em nenhum momento, houve uma rejeição por parte deles. O que foi possível perceber mais tarde com o andamento do curso, foi a estranheza quanto a forma como os exercícios e questões eram tratados, pois não havia uma resposta direta nos textos, o que para eles não era comum, pois segundo os mesmos, em outras disciplinas "bastava procurar no texto e pronto, tudo estava lá!". Eles tinham que ler e interpretar para depois responder. Isso fez com que eles pensassem e discutissem mais entre si sobre o assunto, já que as atividades e os textos eram estudados sempre em grupo.

\section{4 - Caracterizando o professor}

Certamente, quando se pensa na aplicação de uma proposta de ensino, que venha a trazer uma inovação curricular, não podemos esquecer da figura do professor e do seu engajamento nesse processo. Assim, muito se fala em melhorar o ensino de Ciências em nosso País, porém são poucas as pesquisas que levam em consideração o professor, um agente dos mais importantes em todo esse processo. Muitas vezes, a sua ação se limita a de um simples papel de coadjuvante em sua própria atividade profissional, o que o torna simples

\footnotetext{
${ }^{3}$ Contrato didático na definição de Brousseau (1986).
} 
transmissor de conhecimentos, fadado a insucessos e descontentamentos em sua carreira.

Diante disso, Carvalho aponta:

Nenhuma mudança educativa formal tem possibilidade de sucesso se não conseguir assegurar a participação ativa do professor, ou seja, se, de sua parte, não houver vontade deliberada da aceitação e aplicação dessas novas propostas de ensino. (CARVALHO, 2004, p.8)

Assim, a necessidade da formação de grupos de pesquisa onde existam professores do Ensino Médio engajados, torna-se de extrema importância para aumentar a relação entre as Universidades e as escolas, diminuindo a distância que há entre elas, embora existam tentativas de alteração dessa visão através de cursos de formação continuada, como ocorrem atualmente.

Isso ocorre com o professor aplicador desta proposta de pesquisa, que já é membro atuante, há algum tempo, de um grupo de pesquisa que busca a melhoria do ensino de física no Ensino Médio. Esse grupo, que já havia trabalhado em um projeto que tinha como objetivo a melhoria do ensino da Termodinâmica no Ensino Médio das escolas públicas de São Paulo (FAPESP 98/1078-1), era composto por docentes e pós-graduandos da Faculdade de Educação da Universidade de São Paulo e docentes da rede pública do estado de São Paulo. Também atuaram em um projeto que busca atualizar o currículo de Física do Ensino Médio, através de propostas de conteúdos de Física Moderna e Contemporânea. Atualmente, o grupo é constituído de dois docentes da Faculdade de Educação, seis pós-graduandos (entre mestrandos e doutorandos), oito docentes da rede pública estadual e alunos de iniciação científica.

Desse grupo de professores da rede pública, um deles se dispôs a aplicar uma versão piloto do curso de Física das Radiações. Esse professor possui grande experiência no magistério (15 anos) e ainda apresenta uma boa formação, sendo licenciado pelo próprio instituto de Física da Universidade de São Paulo. O trabalho com esse professor foi desenvolvido no Laboratório de Pesquisa em Ensino de Física (LAPEF), vinculado à Faculdade de Educação da mesma instituição, com o apoio da FAPESP. 
Com reuniões semanais nas terças-feiras, no período da tarde, foi possível discutir com ele as atividades que seriam aplicadas com a discussão dos conceitos envolvidos, visto que se tratava de uma área com pouco conhecimento por parte dos professores, já que, possivelmente, não tiveram uma disciplina específica sobre esse conteúdo na graduação, ou nunca aprofundaram mais seus estudos sobre o tema.

Durante grande parte do tempo que estávamos juntos podíamos discutir o conteúdo que seria trabalhado, bem como as atividades a serem desenvolvidas com os alunos. Isso foi essencial para se evitar o constrangimento do professor frente aos alunos, devido a uma aula mal elaborada e com atividades fora de contexto. Portanto, além de saber o conteúdo de sua disciplina, é de extrema importância que o professor também saiba como aplicá-lo em sala de aula, conforme apontam Carvalho \& Gil-Perez:

Dentro dessa perspectiva, o professor precisa saber preparar um programa de atividades que leve seus alunos a construir os conhecimentos, habilidades e atitudes do conteúdo que se propõe a ensinar. (CARVALHO \& GIL-PEREZ, 2001, p. 113)

Dessa forma, o professor desempenhou um papel muito importante na reestruturação das atividades da seqüência didática desenvolvida, uma vez que foram de suas colocações, angústias e elogios, que se pôde recriá-las de forma a encontrar uma melhor aceitação pelos alunos, sendo então um sujeito participante do processo da Transposição Didática, mais especificamente da Transposição Didática Interna ${ }^{4}$.

\footnotetext{
4 Termo usado na teoria da Transposição Didática de Chevallard (1991) que será apresentado no capítulo 2.
} 


\section{CAPÍTULO 2}

\section{A DIDATIZAÇÃO DOS SABERES ESCOLARES}

\section{1 - Introdução}

As relações entre o saber sábio, o saber a ensinar e o saber escolar têm sido motivo de grande preocupação por parte de pesquisadores nas mais diversas áreas de ensino. Na tentativa de explicitar as relações entre esses saberes, muitas análises têm ocorrido a fim de se encontrar referenciais que permitam estudar de maneira mais adequada como ocorrem essas relações.

No ensino de física, a relação entre esses saberes também tem instigado muitas discussões, pois comparando a física que é levada para a sala de aula com a física desenvolvida pelos cientistas, institutos de pesquisa ou nas universidades, embora existam muitas semelhanças entre esses saberes, também existem pontos muito diferentes em relação ao que foi transposto de um nível do saber (saber sábio) para o outro (saber escolar).

Dessa forma, nota-se que o conhecimento para ser transmitido para as novas gerações sofre adaptações, passando por processos de transformação, para que sejam compreensíveis por aquele que aprende.

Neste capítulo, faz-se um estudo sobre o tema na tentativa de entender como ocorrem esses processos de transformação desses saberes. Inicialmente é abordado cada um dos saberes e, em seguida, as contribuições da Teoria da Transposição Didática de Chevallard (1991) para o entendimento desses saberes, bem como as Regras da Transposição Didática apontadas por Astolfi et al (1997).

Assim, utilizamos a Transposição Didática e suas regras como um referencial para analisar e refazer os caminhos percorridos pelos saberes, procurando entender como o savoir savant (saber sábio) transforma-se em saber ensinado, e como ocorre o processo de transformação desse saber, desde a sua origem, até chegar ao ambiente escolar e, finalmente, à sala de aula, o que corresponde a uma didatização dos saberes escolares. 


\section{2 - O saber e suas adaptações para o ambiente escolar}

Quando analisamos o ambiente escolar, mais precisamente a sala de aula, encontramos personagens, como professores e estudantes, que formam uma população localizada, convivendo em um ambiente próprio. $O$ interesse comum está no conhecimento que um transmite para o outro. $\mathrm{O}$ conhecimento trabalhado em sala de aula é um produto que foi construído por pesquisadores e profissionais utilizando processos e métodos próprios, mas que não se apresenta na forma original como foi concebido. O próprio cientista, quando submete seu trabalho à comunidade a que pertence, modifica o seu relato para atender às normas e restrições impostas pela própria comunidade ou outro órgão responsável pela sua divulgação, como por exemplo, revistas especializadas.

Por outro lado, verifica-se que o conhecimento publicado pelos cientistas sofreu modificações até chegar ao estudante. Os responsáveis pela modificação e organização do conhecimento original em um novo texto são, geralmente, os autores dos livros didáticos e de artigos de divulgação científica. Localizamos, assim, mais dois grupos de personagens: os cientistas e os autores que, mesmo não convivendo no ambiente escolar, interferem na sua estruturação. Cada grupo ocupa um lugar na estrutura social com códigos e regras próprias de atuação que devem ser seguidas.

Pode-se considerar que uma das principais funções da escola é a transmissão dos conhecimentos produzidos pela humanidade, mas para que aconteça essa transmissão, é necessário que o conhecimento seja apresentado de maneira que possa ser compreendido e aprendido pelos alunos. É nesse ponto que se manifesta uma das principais transformações do saber $^{1}$, isto é, a adaptação entre o conhecimento produzido e o conhecimento oferecido ao aprendizado.

Convém ressaltar que a adaptação pela qual o conhecimento passa é, muitas vezes, considerada de forma incorreta como uma mera simplificação do saber de referência. Na maioria das vezes isso ocorre na linguagem dos conceitos ou demonstração de fórmulas matemáticas, passando a falsa

\footnotetext{
${ }^{1}$ Utilizaremos aqui os termos saber e conhecimento indistintamente.
} 
impressão de que isso ocorre sempre com o conteúdo no processo de adaptação (SIQUEIRA, 2006).

Dessa forma, para entendermos como ocorrem essas transformações, faremos uso da teoria da Transposição Didática que permite uma análise do processo de transformação do saber ${ }^{2}$, como aponta Alves-Filho:

A Transposição Didática se mostra um instrumento de análise do processo de transformação do conhecimento ou saber. Através dele é possível estabelecer uma argumentação para entender as diferentes formas do saber e suas estruturas organizacionais. (ALVES-FILHO, 2000a, p. 218)

\section{3 - A Transposição Didática}

A noção de Transposição Didática tem-se constituído em algo presente na maioria dos estudos que tratam das relações entre as disciplinas a ensinar e as ciências de referência. No Brasil, tem aparecido também nos textos legais que tratam do ensino na escola básica, como nos Parâmetros Curriculares Nacionais $^{3}$ e nas Diretrizes Curriculares Nacionais para a Formação de Professores da Educação Básica ${ }^{4}$.

O conceito de Transposição Didática foi proposto inicialmente pelo sociólogo Michel Verret ${ }^{5}$, em 1975, sendo usado no ano de 1980 por Yves Chevallard em um trabalho no qual o objetivo era analisar e discutir o conceito matemático de distância, trabalho este intitulado "Un exemple d'analyse de la transposition didactique - la notion de distance". Neste trabalho, Chevallard resgata e faz uso do conceito de Transposição Didática, tornando-o uma teoria conhecida e divulgada na área de ensino de Ciências e Matemática.

Posteriormente, Chevallard publica a obra em 1985 "La transposition didactique: du savoir savant au savoir enseigné", e expõe os principais

\footnotetext{
${ }^{2}$ Nos originais franceses utiliza-se o termo "savoir" (saber), pois parece traduzir mais adequadamente o objeto do processo transformador da Transposição Didática do que 0 termo conhecimento (connaissance), que aparentemente parece ser de entendimento mais amplo e vago.

${ }^{3} \mathrm{O}$ conhecimento matemático formalizado precisa, necessariamente, ser transformado para se tornar passível de ser ensinado/aprendido; ou seja, a obra e o pensamento do matemático teórico não são passiveis de comunicação direta aos alunos. Essa consideração implica rever a idéia, que persiste na escola, de ver nos objetos de ensino cópias fieis dos objetos da ciência. (BRASIL, 1999, p. 39)

4 Sem a mediação da transposição didática, a aprendizagem e a aplicação de estratégias e procedimentos de ensino tornam-se abstratas, dissociando teoria e prática. Essa aprendizagem é imprescindível para que, no futuro, o professor seja capaz tanto de selecionar conteúdos como de eleger as estratégias mais adequadas para a aprendizagem dos alunos, considerando sua diversidade e as diferentes faixas etárias. (BRASIL, 2002, p. 18)

${ }^{5}$ Verret introduziu o termo transposição didática em sua tese Le Temps des Études, defendida em 1975, na França.
} 
conceitos de sua teoria, dentre eles o de sistema didático, o de sistema de ensino, o de noosfera e o de Transposição Didática, dando um corpo estrutural ao conceito de Transposição Didática.

Essa obra gerou algumas críticas e polêmicas, as quais motivaram seu autor a publicar sua segunda edição, em 1991, adicionando um Posfácio. Assim, o estudo da Transposição Didática tem em Chevallard um de seus pioneiros, cujo trabalho se situa no campo da Didática da Matemática. Para Chevallard, o objeto da Didática da Matemática é o sistema didático e mais amplamente o sistema de ensino.

O sistema didático é constituído por três elementos que envolvem o professor, os alunos e o saber, através de uma relação didática, onde estão envolvidos pesquisadores em ensino, professores, políticos, autores de livro, pais de alunos e demais interessados em ensino. Assim, ele destaca:

Os sistemas didáticos são formações que aparecem a cada ano (...): em volta de um saber (designado ordinariamente pelo programa) se forma um contrato didático que tornam esse saber como objeto de um projeto compartilhado de ensino e aprendizagem e que une em um mesmo ambiente docentes e alunos. (CHEVALLARD, 1991, p. 26)

Para representar o sistema didático, Chevallard utiliza o seguinte esquema ${ }^{6}$ :

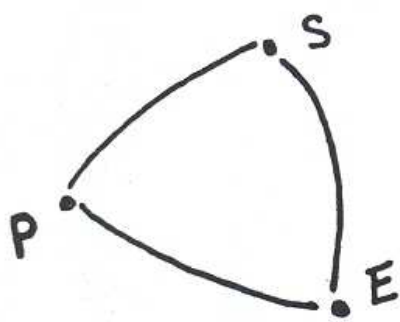

Figura 1 - Representação do sistema didático.

Nesse esquema, $\mathrm{P}$ representa o professor, $\mathrm{E}$ os alunos e $\mathrm{S}$ o saber a ensinar. Para Chevallard, o entorno de um sistema didático está constituído inicialmente pelo sistema de ensino, que reúne o conjunto de sistema didáticos e tem ao seu lado um conjunto diversificado de dispositivos estruturais que

\footnotetext{
${ }^{6}$ Extraído do livro "La transposición didáctica: del Saber Sábio Al Saber Enseñado" de Yves Chevallard (1991).
} 
permitem o seu funcionamento didático e que intervém em diversos níveis (Chevallard, 1991).

Existe, ainda, na periferia do sistema de ensino, uma instância essencial ao funcionamento didático, chamada por Chevallard de noosfera. Nessa instância, ocorre a interação entre o sistema didático stricto sensu e a sociedade em geral. Nela se estabelecem os conflitos, as negociações, as decisões que interferem diretamente nos sistemas didáticos, servindo como fio condutor da Transposição Didática. Dela fazem parte os pais, os pesquisadores, os representantes dos professores e do sistema de ensino, cada um com suas expectativas, visões de mundo e de educação.

Para representar o entorno, a noosfera e o sistema de ensino, Chevallard utiliza o esquema a seguir ${ }^{7}$ :

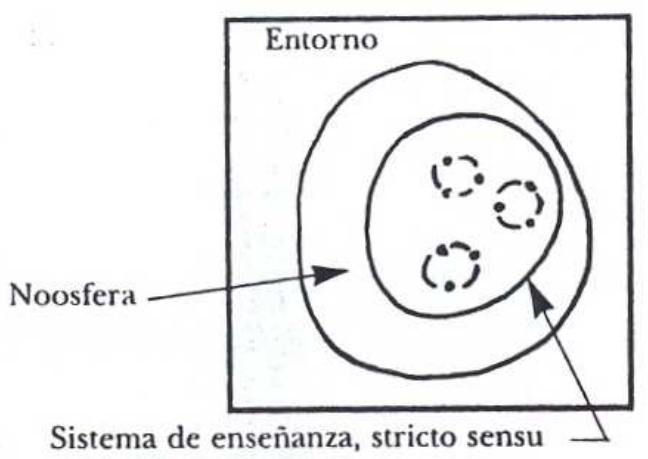

Figura 2 - Representação do entorno, noosfera e sistema de ensino, stricto sensu.

Segundo Chevallard, para que o sistema de ensino seja possível, deve haver uma compatibilização do sistema com os ambientes que o envolvem. No que se refere ao saber, essa compatibilização deve ser tal que não pareça tão distante do saber sábio, o que poderia afetar a sua legitimidade e, por outro lado, deve ser tal que não seja tão próxima do saber dos "leigos", ou saber do senso comum, pois isso poderia banalizar o saber.

Assim, no sistema didático, o saber é um dos elementos da terna professor, aluno e saber. Mas, qual é esse saber e quais as relações do saber ensinado com o saber sábio? São questões que, segundo ele, cabe à didática considerar. O conceito de Transposição Didática remete então ao estudo da

\footnotetext{
${ }^{7}$ Extraído do livro "La transposición didáctica: del Saber Sábio al Saber Enseñado" de Yves Chevallard (1991).
} 
passagem do "saber sábio" ao "saber a ensinar", ao admitir uma eventual e obrigatória distância entre eles, sendo assim, tomado como uma teoria.

Podemos considerar então que a Transposição Didática é uma ferramenta que permite ao didata afastar-se, interrogar as evidências de seu objeto de estudo, sendo uma forma de exercer sua vigilância epistemológica, para que os objetos de saber que serão ensinados não sejam deturpados, substituídos, mas transformados. Nas palavras do próprio Chevallard, a Transposição Didática é:

(...) uma ferramenta que permite recapitular, tomar distância, interrogar as evidências, pôr em questão as idéias simples, desprender-se da familiaridade enganosa de seu objeto de estudo. Em uma palavra, é o que lhe permite exercer sua vigilância epistemológica. (CHEVALLARD, 1991, p.16)

Podemos ver reflexões semelhantes na prática pedagógica do professor diante dos saberes, como aponta Brockington:

Analisar a evolução do saber que se encontra na sala de aula através da Transposição Didática possibilita uma fundamentação teórica para uma prática pedagógica mais reflexiva e questionadora. Para Chevallard isso equivale à capacidade, e necessidade constante, do professor exercer uma vigilância epistemológica em seu magistério. (BROCKINGTON, 2005, p. 88)

Ao considerar a existência da Transposição Didática e procurar desvendá-la, o saber passa a ser uma questão problemática para a didática, avançando para além das questões do ensino-aprendizagem, isto é, da relação professor-aluno. Esse é um aspecto importante da contribuição de Chevallard, pois problematiza a questão do saber, trazendo-a para o campo da didática, que assim passa a se preocupar com saberes específicos, como é o caso do saber físico. Assim, segundo esse autor:

“(...) todo projeto social de ensino e de aprendizagem se constitui dialeticamente com a identificação e a designação de conteúdos de saberes como conteúdos de saberes a ensinar." (CHEVALLARD, 1991, p.39)

De posse dessa constatação, Chevallard apresenta o processo de passagem de uma forma de saber à outra, por meio de transformações adaptativas, com o nome de Transposição Didática: 
Um conteúdo de saber, tendo sido designado como saber a ensinar, sofre a partir de então um conjunto de transformações adaptativas que vão torná-lo apto a ocupar um lugar dentre os objetos de ensino. O trabalho que de um objeto de saber a ensinar o torna um objeto de ensino, é chamado de transposição didática. (CHEVALLARD, 1991, p. 39)

Ainda que o termo transposição nos traga a idéia de algo fixo, "arrastado" de um contexto a outro, o próprio Chevallard o caracteriza como deformação, o que traz um sentido de algo novo, de uma transformação epistemológica do objeto de saber que poderá, assim, ser considerado uma verdadeira criação didática.

Chevallard denomina Transposição Didática Stricto Sensu, a passagem de um conteúdo de saber a uma versão didática deste objeto, mas reafirma que o estudo científico da Transposição Didática supõe considerá-la no sentido amplo, de acordo com o esquema:

objeto de saber $\rightarrow$ objeto a ensinar $\rightarrow$ objeto de ensino

cujas correspondências se fazem relativas ao saber sábio (objeto do saber); ao saber a ensinar (objeto a ensinar) e ao saber ensinado (objeto ensinado).

Um objeto de saber só é introduzido no sistema didático se ele for considerado útil à economia do sistema didático, o que não significa que, uma vez estabelecido como objeto a ensinar, não sofra outras transposições.

\section{4 - Caracterizando os saberes presentes na Transposição Didática}

Pretendemos, neste ponto, caracterizar os diferentes níveis do saber e suas particularidades dentro da Transposição Didática.

\subsection{1 - Saber Sábio}

Podemos considerar o "saber sábio" como o resultado do trabalho de uma comunidade composta basicamente pelos intelectuais e cientistas que constroem aquilo que também é denominado de conhecimento científico. Este é o saber original, aquele considerado como de referência. Este saber se torna 
público através de publicações próprias, tais como revistas e periódicos científicos, ou nos congressos específicos de cada área.

Entretanto, para entendermos um pouco sobre a construção do saber sábio é importante diferenciarmos o momento da produção do saber e o momento em que o mesmo se torna público. Para diferenciá-los vamos descrever em linhas gerais o trabalho de um cientista durante a procura da solução de um problema.

A partir da questão levantada, através de um processo de introversão ou em diálogos com seus pares, o cientista percorre caminhos e atalhos de raciocínio buscando solução para seu problema de pesquisa. $O$ espaço no qual ocorre esse processo construtor é denominado de contexto da descoberta e se refere a uma etapa de trabalho dedicado à busca da resposta desejada.

Dessa forma, após ter encontrado uma resposta satisfatória para sua questão, o cientista necessita socializá-la com seus pares e a comunidade científica, fazendo então uso das normas estabelecidas por ela. Esse momento é denominado de contexto da justificação e se concretiza pela elaboração de artigos ou textos para publicação nos periódicos especializados. Enfim, o texto assume uma forma impessoal, sistemática, com começo, meio e fim e que não mostra as idas e vindas, as dúvidas e os conflitos ocorridos no contexto da descoberta. Como destaca Alves-Filho:

(...) ocorre uma reconstrução racional, que diferencia o processo como o ser humano (cientista) produziu um determinado saber e como o cientista (ser humano) apresenta-o formalmente a seus pares. Nesta discussão percebemos a existência de dois momentos. Entre um e outro, há um processo de reelaboração racional que elimina elementos emotivos e processuais, valorizando o encadeamento lógico e a neutralidade de sentimentos. Aqui, de certa forma, há uma transposição - não didática - mas, diríamos, científica, caracterizada por uma despersonalização e reformulação do saber. (ALVESFILHO, 2000a, p. 224)

Um aspecto que deve ser levado em conta mas que nem sempre é considerado é o tempo utilizado na construção do saber sábio. Muitas vezes, houve a necessidade de se passarem muitos anos para que um saber sábio fosse aceito e compartilhado entre os participantes de uma comunidade. Podemos trazer essa consideração para a Física das Radiações, pois a partir dos estudos realizados por Maxwell, resultando em sua Teoria do 
Eletromagnetismo (1860) que faz a predição da existência de ondas eletromagnéticas, até a geração e detecção de uma onda eletromagnética feita por Hertz (1887), houve uma longa espera de cerca de 17 anos.

Assim, podemos considerar que esse tempo gasto para a elaboração do saber sábio denomina-se de tempo real. Ele está estreitamente ligado ao processo histórico ao qual foi submetido no processo de construção, enquanto que o saber apresentado em revistas e livros didáticos é considerado apenas um tempo lógico, não relacionado com o processo de construção do saber.

\subsection{2 - Saber a Ensinar}

É o saber que se situa entre o saber sábio e o saber ensinado, e segundo Chevallard (1991), corresponde à chamada Transposição Didática Externa, pois ela ocorre fora do ambiente escolar. O processo transformador do saber sábio em saber a ensinar envolve um número de variáveis e de pessoas bem maior do que aquele que ocorre entre o contexto da descoberta e o contexto da justificação.

Em uma primeira análise vemos que nesse nível do saber o conhecimento sofre uma adaptação para uma linguagem mais simples, procurando adequar-se ao ensino e sendo reestruturado de uma forma lógica e atemporal. Dessa forma, somos levados a interpretar que o saber a ensinar é apenas uma mera "simplificação" dos objetos complexos que compõem o saber sábio. Essa interpretação, um tanto discutível, permite interpretações errôneas nas relações escolares, pois revela o desconhecimento de um processo complexo de transformação do saber, como ressalta Chevallard:

Todo projeto social de ensino e aprendizagem se constitui dialeticamente com a identificação e a designação de conteúdos do saber (sábio) como conteúdo a ensinar. (CHEVALLARD, 1991, p. 39)

Os personagens associados a esse nível do saber a ensinar são professores, pesquisadores em ensino, autores de livros didáticos e a opinião pública em geral, que através do poder político influencia de algum modo o processo de transformação do saber. Os cientistas e intelectuais, mesmo não pertencendo a esse nível de poder, também influenciam de maneira indireta, 
porém significativa, as decisões relativas ao saber que será processado e transformado. Assim, esses grupos não só determinam as transformações, mas também definem os objetos do saber sábio alvos de transformações.

Durante esse processo, há o que Chevallard chamou de constrangimentos didáticos, que modificam a natureza do saber sábio ao transformá-lo em objeto de ensino. Assim, podem ser citados e devem ser analisados os processos de descontextualização, de dessincretização, de despersonalização e de descontemporalização (CHEVALLARD, 1991, p. 47).

O saber a ensinar é um saber exilado de suas origens, desligado de sua produção histórica dentro do saber sábio. É, portanto, um saber descontemporalizado e descontextualizado, cuja legitimação não está ligada à autoridade de um produtor. O saber a ensinar supõe, desse modo, um processo de naturalização e é sobre essa natureza de "dado" que a escola exerce a sua jurisdição didática (CHEVALLARD, 1991, p. 17).

O processo de descontextualização do saber consiste no desligamento dos problemas que Ihe deram sentido. Nesse processo há, inicialmente, um invariante, em geral um significante, e há também uma variação, um afastamento, resultante da descontextualização dos significantes, para em seguida se fazer uma recontextualização dentro de um discurso de outra espécie.

Outro processo a ser considerado é o da despersonalização, que começa a ocorrer já na comunidade científica. Um saber, na sua origem, está intimamente ligado ao seu produtor. No entanto, devido à necessidade de dar publicidade a esse saber, ele sofre já um processo de despersonalização, pois deve ser comunicado numa linguagem própria e deve atender a padrões de legitimação. No ensino, esse processo é mais complexo, pois não está submetido às regras de produção, sendo que existem outros aspectos a considerar. Assim, o processo de despersonalização supõe que o saber, ao ser apresentado, não revela o processo de produção, como o produtor o trabalhou, mas mostra o produto; o processo de produção desaparece, para dar lugar à apresentação do produto.

O processo de dessincretização pode ser tomado como resultado da textualização do saber em que o todo é estruturado em partes. Por esse processo, há uma delimitação do que constitui o campo de saber a ser 
ensinado. A textualização do saber tem, ainda, relação direta com o processo de descontextualização e com o processo de despersonalização. Além disso, ao efetivar a publicidade do saber, permite-se também o controle social das aprendizagens.

Apesar desses constrangimentos didáticos, todas essas ações, que atuam diretamente e indiretamente no conhecimento, visam a torná-lo mais compreensível e próximo daquele que será ensinado, onde o foco principal encontra-se no resultado esperado que é a aprendizagem.

\subsection{3 - Saber Ensinado}

Nesse nível do saber ocorre uma segunda Transposição Didática, uma adaptação do saber a ensinar em saber ensinado. Segundo Chevallard, esse processo de transformação é denominado de Transposição Didática Interna, por ser direta e ocorrer no espaço escolar.

Diante disso, o professor passa a ter um papel de grande destaque nessa transposição, porém, não único, pois os alunos, diretores, orientadores, pedagogos e outros agentes escolares, também são representantes desse nível na noosfera.

Analisando esse nível do saber conclui-se que o saber ensinado é aquele que chega ao aluno, pois já sofreu uma primeira transformação, a da Transposição Didática Externa, e agora, passando por uma nova transformação, o da Transposição Didática Interna. Assim, ocorre uma adaptação do conhecimento ao tempo didático ${ }^{8}$, transformando-o em um seqüenciamento de aulas, cabendo ao professor, através do seu planejamento escolar, administrar e adequar o tempo didático ao tempo real ${ }^{9}$.

A ligação entre o tempo real e o tempo didático se manifesta na sala de aula no momento que o professor orienta o processo de ensino-aprendizagem. Os séculos necessários à produção e ao acúmulo do saber sábio devem ser agora ensinados em um período de horas. No tempo real encontramos personagens com estruturas cognitivas formadas e cujo trabalho é a produção

\footnotetext{
${ }^{8}$ Tempo bem definido no espaço escolar, para planejamento e organização do programa escolar. Pode ser entendido como a quantidade de aulas que se dispõe para trabalhar um conteúdo inserido em um planejamento.

${ }^{9}$ Tempo usado por uma série de personagens da noosfera para produzir um determinado saber.
} 
do saber, utilizando o tempo que for necessário, enquanto que no tempo didático, este pertence à estrutura escolar, a qual planeja e organiza seu programa escolar por um período definido. É nesse ponto que a Transposição Didática Interna mostra a importância de seu papel, pois justifica o processo transformador dos saberes, saber a ensinar em saber ensinado, permitindo uma melhor adequação ao espaço escolar.

No nível do saber ensinado, Chevallard aponta para um novo tempo, o tempo de aprendizagem, porém ele diz não haver nenhuma relação ou correspondência entre o tempo didático e o tempo da aprendizagem. A aprendizagem não ocorre por acumulação, no qual os conhecimentos novos se juntam aos antigos. Quando chama atenção para a não correspondência dos tempos, Chevallard entende que a aprendizagem ocorre pela reorganização interna do saber, em um processo no qual ocorre a reinterpretação de aquisições anteriores e modificação dos significados. Essa reorganização é diferente da aquisição linear e programada dos saberes. Torna-se necessário, no nível do saber ensinado, criar artifícios que façam diminuir a diferença entre o tempo didático e o tempo da aprendizagem.

Desse modo, devemos aceitar a Transposição Didática como um fenômeno presente no processo de ensino-aprendizagem e ter consciência de sua importância para o professor que pretende desenvolver um ensino mais contextualizado e com conteúdos menos fragmentados do que aqueles dos livros textos.

O esquema a seguir apresenta o processo da Transposição Didática e os níveis do saber dentro do ambiente da noosfera: 


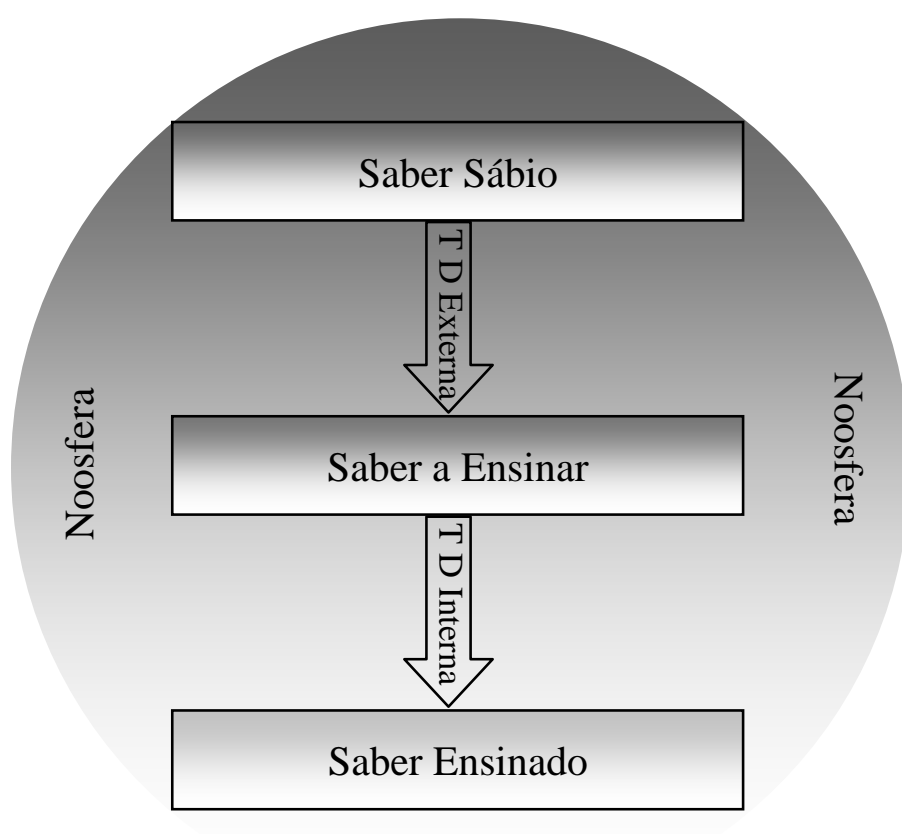

Figura 3 - Representação do processo da Transposição Didática (SIQUEIRA, 2006, p. 74)

\subsection{4 - Analisando a sobrevivência do saber}

Por enquanto, procuramos apresentar a Transposição Didática como um instrumento de análise capaz de refazer os caminhos percorridos pelo saber, desde sua origem (Saber Sábio) até chegar à sala de aula (Saber Ensinado).

Entretanto, Chevallard ressalta algumas características relevantes para ele sobreviver no ambiente escolar. As características destacadas são as seguintes:

a) O saber tem que ser consensual. $O$ saber que vai à sala de aula não pode apresentar dúvidas sobre seu status de "verdade", mesmo que seja um status momentâneo. Isso para que o professor não tenha medo de ensinar algo que a própria ciência não sabe se é verdade, e para que o aluno não tenha dúvidas sobre se o que está aprendendo é correto ou não. "O sistema de ensino parece não saber como avaliar aquilo que $o$ aluno deve saber daquilo que a ciência ainda não sabe." (CHEVALLARD, 1991, p.69) 
b) O saber transposto deveria buscar uma atualização. Espera-se que 0 saber que chega à escola reflita, da melhor maneira possível, o estágio atual de desenvolvimento da pesquisa. Com isso, a atualização se apresenta de duas maneiras: Atualidade moral, ligada ao currículo, mostrando se aquele saber que será transposto tem importância reconhecida pela sociedade e pelos pais, não se tornando um saber obsoleto que pode ser ensinado até mesmo pelos pais ou em outro ambiente que não seja a sala de aula. Ou seja, o saber que será transposto deverá estar nem muito afastado do saber de origem, nem muito próximo do saber dos pais. Atualidade biológica, ligada diretamente a sua área de conhecimento. O saber transposto deve estar de acordo com a ciência vigente, deixando os conceitos que foram superados para serem ensinados somente em uma perspectiva histórica.

c) O saber tem que ser operacional. O saber que vai para a sala de aula tem que ser capaz de gerar algum tipo de atividade, como exercícios, tarefas ou algum tipo de trabalho que tenha como objetivo a conceituação do saber, sendo possível formar seqüências didáticas. Essa é uma característica importante, porque está ligada diretamente à avaliação. Saberes que não apresentam nenhum tipo de atividade que possa levar a uma avaliação de seu aprendizado estão fadados a não permanecer na escola.

d) O saber deveria permitir uma criatividade didática. Essa característica implica a criação de atividades de uso exclusivo da escola, ou seja, objetos que não possuem similares no Saber Sábio, tornando-se criações que têm existência garantida somente na sala de aula, como é o caso de atividades que envolvam associação de resistores e escalas termométricas, por exemplo.

e) O saber tem que ser terapêutico. O saber tem que mostrar uma adaptação ao sistema didático, ou seja, só permanece na escola aquele saber que já se verificou que dá certo, dentro das características 
ressaltadas, e aqueles que não se ajustam ao sistema didático são excluídos.

\subsection{5 - As Regras da Transposição Didática}

Tomando como referência o trabalho de Chevallard (1991), Astolfi et al (1997) apresenta de forma didática "as várias etapas ou regras, que conduzem à introdução do saber sábio até o saber a ensinar" (pg. 18). As cinco regras apresentam os objetivos que norteiam o processo de transposição e são as seguintes:

\section{Regra I - Modernizar o saber escolar}

A ciência, nos últimos anos, vem produzindo cada vez mais conhecimentos e estes chegam cada vez mais depressa para a população em geral, em forma de novos aparelhos e dispositivos mais modernos. Esse desenvolvimento poderia ser acompanhado por uma releitura moderna e contemporânea dos livros didáticos, fazendo juz ao alto desenvolvimento tecnológico. Isso poderia contribuir para um novo olhar do aluno sobre a ciência moderna. De certa forma, isso já acontece, porém a maioria desses temas são tratados de forma superficial, ficando apenas como tópicos que permeiam a física clássica tradicional dos livros didáticos ou descritos brevemente nos últimos capítulos destes livros, nos mesmos moldes dos já existentes. "A modernização dos saberes escolares é uma necessidade, pois legitima o programa da disciplina, garantindo seu lugar no currículo" (BROCKINGTON, 2005, p.109). Conforme Astolfi:

Em diferentes disciplinas, parece ser necessário aos especialistas colocar em dia os conteúdos de ensino para aproximá-los dos conhecimentos acadêmicos. Neste caso, freqüentemente criam-se comissões que tomam por base vários trabalhos e proposições anteriores difundidas na noosfera. (ASTOLFI, 1997, p.182) 


\section{Regra II - Atualizar o saber escolar}

O saber tem que ser renovado, atualizado, porque esse saber tratado no sistema didático envelhece (CHEVALLARD, 1991). Se afastado do núcleo de pesquisa do saber sábio (isso faz com esse saber não seja mais reconhecido como atual pelo saber original) e modificando-se para toda a sociedade, o saber do aluno estaria se aproximando do saber dos pais (banalizando o saber, porque o professor estaria ensinado algo diluído na cultura cotidiana). Esse envelhecimento torna o sistema didático obsoleto do ponto de vista da sociedade, visto que os próprios pais poderiam transmitir esse conhecimento. Isso gera uma incompatibilidade do sistema didático com seu entorno.

Para retomar a compatibilidade, é necessária a instauração de uma corrente proveniente do Saber Sábio que traga um saber ainda não difundido amplamente. "Para esta renovação, a modernização julgada necessária do lado do Saber Sábio, se soma a uma necessidade de renovação curricular do lado do ambiente do sistema educativo" (ASTOLFI, 1997, p.182).

\section{Regra III - Articular o saber novo com o antigo}

O saber novo se articula melhor quando apresentado para explicar um saber antigo, mas não de uma maneira radical, tentando refutar ou negar o saber anterior. Isso poderia gerar o risco de o aluno ver o novo saber escolar como algo instável, acreditando que ele sempre será substituído por um mais novo que virá em seguida. Poderá, também, gerar um estado de "questionamento" permanente, provocando dificuldades na condução do processo de ensino. Segundo destaca Astolfi:

Entre os vários objetos do Saber Sábio suscetível a modernização e para diminuir a obsolescência, alguns são escolhidos porque permitem uma articulação mais satisfatória entre o novo que se tenta introduzir, e o velho já provado no sistema e do qual será necessário conservar alguns elementos reorganizados. (ASTOLFI, 1997, p.183)

\section{Regra IV - Transformar um saber em exercícios e problemas}


O Saber Sábio que trouxer maiores possibilidades de exercícios e atividades certamente será melhor aceito pelo sistema didático. Isso porque os exercícios e atividades são parte preponderante no processo de avaliação. Assim, esses conteúdos terão uma vantagem, ou melhor, uma preferência no processo da Transposição Didática. Alves-Filho (2000) destaca que essa é a regra de maior importância no processo de transformação do saber, pois está ligada diretamente ao processo de avaliação. A aquisição desse saber pelo aluno pode ser confirmada através da habilidade dele em solucionar exercícios e problemas:

A seleção vai ocorrer a partir da facilidade particular de certos conteúdos para gerar um número grande de exercícios ou atividades didáticas, até mesmo quando estes são nitidamente descontextualizados quanto a sua função, em relação ao conceito original. (ASTOLFI, 1997, p.183)

\section{Regra V - Tornar um conceito mais compreensível}

Como vimos, há uma perda da linguagem original na transformação do Saber Sábio em Saber a Ensinar. O saber passa a ser escrito em uma linguagem mais próxima das pessoas que não fazem parte da comunidade que compõe o Saber Sábio. Isso faz com que esse saber se torne mais próximo dos alunos e, dessa forma, sua compreensão poderá ser facilitada, tendo como objetivo a melhoria do aprendizado desse saber por parte do aluno:

Um conceito (...) é visto como capaz de diminuir as dificuldades conhecidas como as que os alunos encontram. (...) a coisa do professor é um texto do saber. É então ao texto do saber que ele devolve a etiologia (ciência das causas) o fracasso e, por conseguinte, será nas variações do texto do saber que irá encontrar uma arma terapêutica para as dificuldades encontradas. Podemos aqui medir o caminho do que vai da primeira justificação que introduz o conceito, tal qual como aparece nas instruções, ao interesse que leva conscientemente o professor (diferentes daquele do programa) a este mesmo conceito. (CHEVALLARD e JOSHUA, 1982, p. 45)

\section{5 - A Física das Radiações à luz da Transposição Didática}

O principal intuito deste trabalho é o de inserir um novo saber no Ensino Médio, neste caso, a Física das Radiações, através da proposta de uma 
seqüência didática de ensino ${ }^{10}$. Assim, esse conhecimento assume o papel do saber a ensinar e, a partir de agora, será analisado com a teoria da Transposição Didática.

Podemos considerar que a Física das Radiações pertence a uma área do conhecimento contemporâneo que busca compreender quais as formas de radiações existentes, como se dá a sua interação com a matéria, além das possíveis formas de detectar as suas diferentes manifestações.

Partindo-se disso, ela permitiu uma releitura do mundo físico que vivemos, trazendo discussões e questionamentos até então desconhecidos, além de garantir avanços tecnológicos para a sociedade, onde se destacam as inovações no campo das telecomunicações, da medicina, do entretenimento, etc.

Atualmente, a Física das Radiações encontra-se bem estruturada e solidificada, utilizando-se dos conceitos da Teoria do Eletromagnetismo de Maxwell (Modelo Ondulatório) e da Teoria dos Quanta de Planck e Einstein (Modelo Corpuscular). Essas teorias se complementam uma vez que justificam, por exemplo, o caráter de dualidade da luz, sendo consideradas pela comunidade científica como modelos consolidados, um saber verdadeiro, o que caracteriza um saber consensual.

Além disso, a Física das Radiações traz uma atualização do saber que já se encontra em sala de aula, através de uma nova visão da natureza, feita pela Teoria Quântica, onde o elétron não pode mais ocupar qualquer posição na eletrosfera do átomo, mas apenas níveis de energia bem definidos, denominados de estados estacionários ou quânticos.

Nessa atualização encontra-se a atualidade biológica, pois os conceitos que foram superados (visão clássica) acabam sendo apenas retomados, muitas vezes, por uma questão histórica (evolução dos modelos atômicos), de forma a justificar a inserção do novo modelo (visão moderna). Também vemos claramente aspectos da atualização moral, pois é possível compreender um pouco mais sobre as radiações, sua interação com a matéria através do Efeito Fotoelétrico, levando a um entendimento maior de aparelhos como as células fotoelétricas encontrados na porta de um elevador. Dessa forma, justifica-se a

\footnotetext{
${ }^{10}$ Esta seqüência, sua construção e organização serão relatadas no capítulo 3.
} 
presença da Física das Radiações no currículo por ser um saber que está longe do alcance dos pais e muito presente na sociedade moderna.

Como um saber atual, encontramos muitos itens que mostram a Física das Radiações como um conhecimento contemporâneo como, por exemplo, a grande mudança gerada pelo mundo sem fio (Wireless), onde destacamos tecnologias como Bluetooth, que certamente hoje é um ícone entre as mais diversas classes da sociedade, afinal os celulares contribuíram para essa massificação, principalmente entre os jovens que o utilizam como simples ferramentas de lazer, sem muitas vezes compreenderem os conceitos envolvidos por tais tecnologias.

Diante disso, acreditamos também que esse conhecimento apresenta grande poder operacional e de criatividade didática, principalmente quanto à possibilidade de criação de atividades e situações de aprendizagem, como exercícios, tarefas ou mesmo uma atividade prática, o que pode garantir a permanência desse conhecimento no ambiente escolar, não havendo objetos semelhantes no saber sábio. Quanto ao caráter terapêutico, é necessária a sua inserção no Ensino Médio, aguardando-se que ocorra a sua adaptação ao sistema didático, o que envolve a variável tempo. Certamente a criatividade didática poderá ser um fator determinante para a adaptação desse conhecimento à sala de aula. Todas essas características ficarão mais claras no capítulo seguinte. 


\section{CAPÍTULO 3}

\section{O CURSO DE FÍSICA DAS RADIAÇÕES}

\section{1 - Introdução}

A necessidade de se reestruturar as práticas de ensino envolve a mudança de paradigmas, portanto, formas de pensar e atuar. O sucesso do processo de ensino-aprendizagem depende de vários fatores, como por exemplo, um currículo factível de ser executado em sala de aula, a formação continuada dos professores, uma abordagem dos conteúdos que estimule a aprendizagem e, principalmente, uma estrutura constituída de bons materiais pedagógicos, como apontam Carvalho e Gil-Perez:

Dentro dessa perspectiva, o professor precisa saber preparar um programa de atividades que leve seus alunos a construir os conhecimentos, habilidades e atitudes do conteúdo que se propõe a ensinar. (CARVALHO e GIL-PEREZ, 2001, p. 113)

Nesse sentido, a criação de materiais por parte dos professores e o uso daqueles já existentes com as características já apontadas, certamente terá um papel fundamental em qualquer implementação de reforma do ensino de física. Essa prática já vem sendo desenvolvida no Brasil, porém de forma bem tímida, e tem apresentado bons resultados (TERRAZZAN, 1994; SILVA, 2002; CANATO, 2003; MOZENA, 2003; BROCKINGTON, 2005; SIQUEIRA, 2006). Ainda assim, podemos considerar que há uma escassez de materiais didáticos destinados à inserção da FMC no Ensino Médio, conforme já apresentado neste trabalho, e quanto ao tema Física das Radiações, o problema toma uma proporção ainda maior. Refletindo sobre essa situação e diante desse cenário, foi elaborada uma proposta de seqüência didática sobre a Física das Radiações que procura introduzir os principais conceitos dessa área a alunos do Ensino Médio.

Com essa proposta pretende-se contemplar o espírito investigativo, de maneira a incentivar e despertar nos alunos uma mudança de comportamento 
durante as aulas, propiciando uma maior participação e interação entre alunos e conhecimento, além de uma reflexão sobre os saberes do professor para alcançar os objetivos didáticos de uma proposta inovadora.

\section{2 - A escolha dos conteúdos e a seqüência didática do curso}

Elaborar uma seqüência didática para um curso de forma a se tornar uma proposta inovadora envolve uma gama de detalhes que, se não levados em consideração, aumentam as chances de obtenção de um produto final semelhante aos muitos encontrados nos meios editoriais atuais, ou seja, um material descontextualizado e muito afastado da realidade dos alunos que cursam o Ensino Médio, como apontam Teixeira e Krapas ${ }^{1}$ (2005), que constataram que em muitas situações o saber de referência (saber sábio) pode se tornar irreconhecível. Assim, Chevallard (1991), chama a atenção para a necessidade da "vigilância epistemológica", isto é, a preocupação que deve existir quando se procura realizar a didatização dos saberes escolares, preocupação esta que deveria manter a correspondência entre os dois saberes.

Assim, não é nossa intenção produzir um material que pouco se identifique com a nossa proposta inicial de trabalho. Entretanto, em qualquer movimento relacionado em trazer o conhecimento científico para a sala de aula, os recortes sofridos pelos saberes são inevitáveis mas, conforme prevê a Transposição Didática, não pode haver um distanciamento grande entre o saber sábio (saber de referência) e aquele que foi adaptado como um saber a ensinar, pois se corre o risco de chegarmos a uma mera simplificação de conteúdos, na tentativa de facilitar a sua compreensão por parte dos estudantes, o que acaba em verdade, dificultando o aprendizado, como apontam Carvalho e Gil-Perez:

Análises feitas nos livros didáticos para adolescentes têm mostrado que, na procura de "simplificar o conteúdo", seus autores somente tornam estes muito

\footnotetext{
${ }^{1}$ Trabalho apresentado no VII Congresso de Enseñanza de Las Ciências de 2005, cujo título original era "Reflexões sobre a Transposição Didática da Lei de Coulomb". Neste trabalho os autores têm a proposta de identificar possíveis nuances de dogmatização na apresentação da lei de Coulomb pelos mais expressivos livros didáticos brasileiros do Ensino Médio.
} 
mais áridos e difíceis que os usados por universitários. (CARVALHO e GILPEREZ, 2001, p. 108)

Diante disso, e empregando a vigilância epistemológica em nosso trabalho, durante a escolha dos conteúdos, procurou-se usar também como elemento norteador do trabalho a elaboração de uma seqüência didática que trouxesse uma nova visão da natureza e do mundo das radiações, sem o rigor matemático característico dessa área, porém que permitisse ao aluno a noção de uma área da física bem estruturada e em permanente evolução.

Para a escolha dos conteúdos, encontramos na literatura três vertentes representativas de abordagens metodológicas para a inserção da Física Moderna e Contemporânea no nível médio. A primeira delas diz respeito à exploração dos limites dos modelos clássicos, que é defendida por Gil el al. (1988; 1993, apud ALVETTI, 1999) da Universidade de Valência, na Espanha, na qual os autores defendem a necessidade de apresentar a crise instaurada na Física Clássica e as questões que levaram a esse acontecimento como um limite para a inserção de elementos da Física Moderna, ao invés de mostrar as diferenças entre a visão clássica e a moderna sobre o comportamento da matéria.

A segunda proposta é atribuída às pesquisas de Fischler e Lichtfeldt (1992), da Universidade Livre de Berlim, na Alemanha, que defendem a não utilização de referências aos modelos clássicos, pois segundo eles a aprendizagem de Física Moderna é dificultada porque o ensino freqüentemente usa analogias clássicas. Os autores sugerem algumas premissas básicas para a abordagem da Mecânica Quântica no Ensino Médio, e a partir delas elaboram um programa. Esse programa tem a seguinte seqüência (FISCHLER e LICHTFELDT, 1992, p. 184): difração de elétrons; experimento de dupla fenda com elétrons; princípio de incerteza de Heisenberg; quantização de energia para um potencial poço - quadrado e para o átomo de Hidrogênio; experimento de Franck-Hertz e análise espectroscópica; objetos quânticos de luz: fótons e problemas de interpretação. Esse programa foi aplicado em onze cursos secundaristas da cidade de Berlim, e segundo os autores, os resultados foram satisfatórios.

A terceira metodologia é a formulada por Arons (1990), da Universidade 
de Washington, nos Estados Unidos. O autor defende a escolha de tópicos especiais, indicando que não se pode trabalhar todos os conceitos da Física Moderna no nível médio, uma vez que parte dos estudantes não consegue assimilar muitos dos conteúdos presentes nessa área, sendo suficiente explorar alguns conceitos como elétrons, fótons, núcleos, estrutura atômica e talvez os primeiros aspectos qualitativos da relatividade. Caso se opte por ensinar o modelo de Bohr, por exemplo, a programação curricular seria estabelecida identificando-se tópicos essenciais, tanto da Física Clássica quanto da Moderna, indispensáveis para se entender os experimentos e argumentos que definem elétrons, núcleos atômicos e fótons, deixando-se de incluir os assuntos não-fundamentais.

Finalmente, encontramos em Terrazan (1994) um posicionamento quanto a qual metodologia seguir. Para o autor, cabe ao professor da escola de Ensino Médio decidir qual é a metodologia mais adequada ao desenvolvimento de cada área temática, sendo que a história da ciência, as múltiplas abordagens metodológicas e a reflexão contínua sobre sua prática pedagógica constituem ferramentas importantes para que o professor desenvolva uma estratégia didática inovadora.

Ainda sobre o problema da escolha dos conteúdos prioritários para o Ensino Médio, este questionamento também foi investigado por Ostermann e Moreira (1998 apud OSTERMANN; MOREIRA, 2000a), que obtiveram uma lista consensual de quais tópicos de Física Moderna deveriam ser ensinados nas escolas ou serem objeto de atenção especial na formação de professores, a partir da consulta a físicos, pesquisadores em Ensino de Física e professores de física do Ensino Médio. A relação final desses tópicos incluiu assuntos como efeito fotoelétrico, átomo de Bohr, leis de conservação, radioatividade, forças fundamentais, dualidade onda-partícula, fissão e fusão nuclear, origem do universo, raios- $X$, metais e isolantes, semicondutores, laser, supercondutores, partículas elementares, Teoria da Relatividade Restrita, Teoria do Big Bang, estrutura molecular, fibras ópticas, entre outros.

Assim, a partir das metodologias apresentadas e considerando-se a proposta e objetivos do curso de Física das Radiações, identificamo-nos com as idéias apresentadas por Arons, Ostermann e Moreira. São essas idéias que nortearam a elaboração da proposta da seqüência didática, mesmo ciente de 
não ser esta metodologia um consenso quanto à escolha dos conteúdos ou tópicos essenciais. Logo, optamos sem perder o foco do trabalho, pela escolha de conceitos essenciais ao estudo da Física das Radiações, tais como: radiação eletromagnética, onde se discutem as diversas radiações presentes em seu espectro; radiações corpusculares, onde se apresentam as radiações formadas por partículas; interação da radiação com a matéria e seus efeitos, onde se procuram caracterizar as radiações quanto ao caráter ionizante e não-ionizante e, finalmente, os detectores de radiação, onde são tratados os mecanismos e dispositivos usados para "enxergar" estas radiações.

Através dessa escolha conseguimos determinar quais os tópicos da Física Clássica que seriam essenciais para a elaboração do curso, onde podemos destacar a carga elétrica em repouso, campo elétrico, carga elétrica acelerada, campo magnético, e a relação entre os campos elétrico e magnético. Assim, procurou-se criar condições favoráveis para inserir a Física das Radiações no Ensino Médio, tornando a sua aplicação mais bem aceita e minimizando as rejeições. Optamos, dessa forma, por apresentar os aspectos fundamentais dos saberes considerados clássicos, com o uso de modelos e o processo de criação científica, buscando desde o início do curso propiciar aos alunos notar a diferença entre os modelos clássicos presentes em sala de aula e os modelos da Física Moderna e Contemporânea que estavam sendo inseridos.

Acreditamos, portanto, ter desenvolvido uma abordagem fenomenológicoconceitual. Fenomenológico no sentido de favorecer a criação de uma nova percepção e conceitual na medida em que os fenômenos escolhidos devem ser suficientemente simples (elementares) e dirigidos de forma que a essência semântica dos primeiros conceitos envolvidos fique evidente (GRECA e MOREIRA, 2001) e possa, então, guiar o nosso trabalho, abrindo um maior número de opções e adequando melhor nossa abordagem pedagógica ao perfil dos alunos e ao andamento do curso.

O curso foi previsto para ter uma duração de 19 aulas, número este que corresponde a aproximadamente um bimestre do ano letivo, a ser desenvolvido na terceira série do Ensino Médio, no segundo semestre das turmas regulares ou segundo bimestre das turmas da modalidade EJA, uma vez que até esse 
período os conceitos da Física Clássica citados já pudessem ter sido trabalhados.

Assim, a seqüência didática escolhida ficou definida da seguinte forma para o curso de Física das Radiações:

- Bloco 1 - Radiações eletromagnéticas (8 aulas);

- Bloco 2 - Radiações corpusculares (5 aulas);

- Bloco 3 - Interação das radiações com a matéria e seus efeitos (3 aulas);

- Bloco 4 - Detectores de radiação (3 aulas).

Convém ressaltar que o curso foi dividido em quatro blocos. Em cada bloco temos atividades de caráter investigativo e textos que auxiliam a sistematização dos conceitos. Na tabela a seguir encontramos a seqüência didática com os respectivos temas, conteúdos, objetivos e atividades presentes em cada bloco:

\begin{tabular}{|c|c|c|c|}
\hline TEMA & CONTEÚDOS & OBJETIVOS & ATIVIDADES \\
\hline \multirow[t]{2}{*}{$\begin{array}{c}\text { Bloco } 1 \text { - } \\
\text { Radiações } \\
\text { eletromagnéticas } \\
\text { (8 aulas) }\end{array}$} & $\begin{array}{l}\text { - Radiação } \\
\text { eletromagnética } \\
\text { - Espectro } \\
\text { eletromagnético } \\
\text { - Aplicações das } \\
\text { radiações } \\
\text { eletromagnéticas }\end{array}$ & $\begin{array}{c}\text { Neste bloco } \\
\text { pretende-se } \\
\text { primeiramente } \\
\text { fazer uma distinção } \\
\text { entre os tipos de } \\
\text { radiações } \\
\text { (eletromagnéticas e } \\
\text { corpusculares). Em } \\
\text { seguida são } \\
\text { discutidos os vários } \\
\text { tipos de radiações } \\
\text { eletromagnéticas } \\
\text { (ondas de rádio, } \\
\text { microondas, raios } \\
\text { infravermelhos, luz } \\
\text { visível, raios } \\
\text { ultravioleta, raios X } \\
\text { e raios gama), suas } \\
\text { características e } \\
\text { aplicações. }\end{array}$ & $\begin{array}{c}\text { Atividade } 1 \text { - } \\
\text { Questionário Inicial } \\
\text { Atividade } 2 \text { - } \\
\text { Análise da chama } \\
\text { de uma vela } \\
\text { Atividade } 3 \text { - } \\
\text { Transmissor de } \\
\text { ondas } \\
\text { eletromagnéticas } \\
\text { Atividade } 4 \text { - } \\
\text { Dispersão da luz } \\
\text { Atividade } 5 \text { - } \\
\text { Analisando } \\
\text { radiografias } \\
\text { Vídeo do telecurso } \\
\text { 2000: Espectro } \\
\text { eletromagnético }\end{array}$ \\
\hline & $\begin{array}{l}\text { - Átomo e o modelo } \\
\text { atômico } \\
\text { - Interação nuclear }\end{array}$ & $\begin{array}{l}\text { Neste bloco } \\
\text { pretende-se discutir } \\
\text { os vários tipos de } \\
\text { radiações } \\
\text { corpusculares, ou }\end{array}$ & $\begin{array}{c}\text { Atividade } 6 \text { - } \\
\text { Ordem de } \\
\text { grandeza e } \\
\text { potência de dez }\end{array}$ \\
\hline
\end{tabular}




\begin{tabular}{|c|c|c|c|}
\hline $\begin{array}{c}\text { Bloco } 2 \text { - } \\
\text { Radiações } \\
\text { corpusculares } \\
\text { (5 aulas) }\end{array}$ & $\begin{array}{l}\text { e a estabilidade do } \\
\text { núcleo } \\
\text { - Decaimentos } \\
\text { radioativos } \\
\text { - Descoberta da } \\
\text { Radioatividade }\end{array}$ & $\begin{array}{c}\text { seja, aquelas } \\
\text { constituídas por } \\
\text { partículas } \\
\text { elementares } \\
\text { (partículas alfa, } \\
\text { prótons, elétrons, } \\
\text { pósitrons e } \\
\text { nêutrons), suas } \\
\text { características e } \\
\text { aplicações. }\end{array}$ & $\begin{array}{c}\text { Atividade } 7 \text { - } \\
\text { A estabilidade } \\
\text { nuclear e os } \\
\text { elementos } \\
\text { radioativos } \\
\text { Vídeo da TV } \\
\text { Ontário: A } \\
\text { descoberta da } \\
\text { Radioatividade }\end{array}$ \\
\hline $\begin{array}{c}\text { Bloco } 3 \text { - } \\
\text { Interação das } \\
\text { radiações com a } \\
\text { matéria e seus } \\
\text { efeitos } \\
\text { (3 aulas) }\end{array}$ & $\begin{array}{l}\text { - Interação da } \\
\text { Radiação com a } \\
\text { Matéria e seus } \\
\text { Efeitos }\end{array}$ & $\begin{array}{c}\text { Neste bloco } \\
\text { pretende-se fazer } \\
\text { uma discussão } \\
\text { sobre a diferença } \\
\text { entre as radiações } \\
\text { ionizantes e não- } \\
\text { ionizantes, bem } \\
\text { como a } \\
\text { caracterização dos } \\
\text { efeitos de cada } \\
\text { uma dessas } \\
\text { radiações ao } \\
\text { interagirem com a } \\
\text { matéria. }\end{array}$ & $\begin{array}{c}\text { Atividade } 8 \text { - } \\
\text { Radiação-matéria }\end{array}$ \\
\hline $\begin{array}{l}\text { Bloco } 4 \text { - } \\
\text { Detectores de } \\
\text { radiação } \\
\text { (3 aulas) }\end{array}$ & $\begin{array}{l}\text { - Detectores de } \\
\text { radiação }\end{array}$ & $\begin{array}{c}\text { Neste bloco } \\
\text { pretende-se fazer } \\
\text { uma discussão } \\
\text { sobre os tipos de } \\
\text { detectores de } \\
\text { radiação que o } \\
\text { homem construiu, } \\
\text { como por exemplo, } \\
\text { o Contador Geiger } \\
\text { e o Cintilômetro, e } \\
\text { aqueles que nós } \\
\text { dispomos } \\
\text { naturalmente. }\end{array}$ & $\begin{array}{c}\text { Atividade } 9 \text { - Papel } \\
\text { fotográfico }\end{array}$ \\
\hline
\end{tabular}

Assim, decidimos partir de uma fenomenologia mais próxima possível da vivida pelo aluno, acreditando que com isso possamos despertar maior interesse deles em conhecer o conteúdo a ser desenvolvido. Entretanto, surge um questionamento: seria essa a melhor seqüência didática a ser explorada?

Diante disso, aplicamos a proposta em caráter de projeto piloto, com uma seqüência baseada no estudo das ondas eletromagnéticas e do espectro eletromagnético. Assim, iniciamos o estudo das radiações através da Física 
Clássica e as ondas eletromagnéticas, para mais adiante, introduzirmos a Física Moderna e os corpúsculos da luz (fótons).

A seqüência foi aplicada no segundo semestre de 2007, com êxito e sem aspectos de rejeição por parte dos alunos. Convém ressaltar que a aplicação só não foi mais tranqüila devido a problemas de diversas ordens como feriados, semana cultural, reuniões pedagógicas, campeonatos e outros acontecimentos na escola, que não permitiram o cumprimento fiel das datas estipuladas das aulas, o que não comprometeu o conteúdo. Mesmo assim, esse estudo piloto foi de grande utilidade para fazermos uma primeira avaliação da seqüência didática e suas atividades, permitindo corrigi-las e adequá-las à proposta e objetivos iniciais.

Uma primeira constatação de nossa avaliação foi quanto à necessidade efetiva de antes de iniciarmos a aplicação da proposta, introduzir um estudo qualitativo das ondas e suas características, onde são apresentados conceitos importantes para todo o desenvolvimento do curso, como a conceituação de onda, comprimento de onda, freqüência, energia e a relação entre essas grandezas. Isso se fez necessário, uma vez que grande parte dos alunos não tiveram contato com tais conteúdos nas séries anteriores e estranharam os termos usados no estudo da luz visível, ou seja, termos como comprimento de onda e freqüência para tratarmos da luz. Através desse estudo preliminar e de outros aspectos da Física Clássica já mencionados para a introdução da Física Moderna, foi possível a abordagem sobre as ondas eletromagnéticas e 0 espectro eletromagnético de uma forma menos abrupta e conflitante quanto aos aspectos da Física Clássica, de forma a se chegar nas discussões quanto à interpretação quântica das ondas eletromagnéticas.

Assim, iniciamos 0 estudo das radiações através das radiações eletromagnéticas e o espectro eletromagnético, acreditando que com essa abordagem estaríamos bem próximos dos alunos, despertando neles um maior interesse, afinal, dentro do espectro eletromagnético temos a presença de radiações não visíveis aos nossos sentidos como os raios- $X$ e os raios gama, porém detentores de efeitos impressionantes ao atravessarem nossos corpos.

Portanto, chegamos a uma seqüência de aulas na qual as radiações e suas interações com a matéria encontram-se presentes, além de abordar a necessidade de instrumentos para fazer a sua identificação. A partir dessa 
seqüência, conseguimos chegar durante a aplicação do curso até os detectores de radiação, no que diz respeito ao cronograma das aulas.

Acreditamos que, com essa seqüência didática, podemos abordar efetivamente em sala de aula os principais conceitos envolvidos na Física das Radiações, e gerar discussões importantes acerca da história, filosofia e epistemologia da ciência, mostrando um pouco do funcionamento da ciência contemporânea, alcançando os objetivos propostos pelo curso.

Finalmente, acreditamos que a seqüência levada aos alunos está bem estruturada e obedece a uma lógica didática, favorecendo o processo de ensino-aprendizagem, além de propiciar um contato com o conhecimento de uma forma diferente daquela apresentada na maioria dos livros didáticos. Para isso, a permanente vigilância epistemológica proposta por Chevallard e a observância das regras para a didatização dos saberes escolares elaboradas por Astolfi foram fundamentais.

\section{3 - As atividades do curso de Física das Radiações}

É certo que em qualquer proposta de ensino, as atividades desempenham um papel fundamental e incontestável. Admitidas tais considerações, em nossa proposta essa preocupação foi um fator determinante durante a sua construção. Aqui, as atividades dão um dinamismo ao curso, fornecendo situações e problemas aos alunos de forma a motivá-los às discussões, além de dar a eles a oportunidade de exporem suas idéias sobre os fenômenos estudados num ambiente encorajador, para que adquiram segurança e envolvimento nas práticas científicas, como indicam Capecchi e Carvalho:

É, portanto, necessária a criação de um espaço para a fala dos alunos nas aulas. Através da fala, além de poder tomar consciência de suas próprias idéias, os alunos também têm a oportunidade de poder ensaiar o uso do gênero discursivo, que carrega consigo características da cultura científica. (CAPECCHI e CARVALHO, 2000, p. 95)

A dificuldade em elaborar atividades sobre o tema, talvez, justifique a pequena quantidade de atividades disponíveis na literatura e com chance de serem reproduzidas e aplicadas em sala de aula, pois as experiências 
conhecidas, muitas vezes, fazem uso de aparelhos sofisticados e caros, o que impossibilita a sua realização nas escolas.

Além do caráter dinâmico das atividades, elas também serviram como referencial de análise para o curso, já que as utilizamos como marcadoresestruturantes $^{2}$ de nossa seqüência, marcadores estes que possibilitam avaliar se a seqüência com as atividades propostas se tornou coesa, lógica e possível de ser compreendida pelos alunos e, ainda, avaliar o entendimento do conteúdo. Essa ferramenta é motivadora para maiores discussões sobre o assunto.

${ }^{2}$ Serão tratados no capítulo 4 deste trabalho. 


\section{CAPÍTULO 4}

\section{A ANÁLISE DOS DADOS}

\section{1 - Introdução}

Apresentaremos neste capítulo a análise dos dados obtidos em nossa pesquisa. Para a realização dessa tarefa, utilizamos um instrumento construído a partir da Transposição Didática para analisar a estrutura do curso, centrada na idéia dos "marcadores-estruturantes". Dentro da Transposição Didática, Brockington (2005) e Siqueira (2006), desenvolveram e aperfeiçoaram a noção de marcador. A idéia inicial de marcador foi elaborada por Brockington (2005) para estruturar e analisar uma seqüência didática sobre o comportamento dual da luz:

\footnotetext{
O termo marcador foi cunhado durante nossas reflexões sobre a necessidade de buscar novos rumos para a inserção da FMC nas salas de aula. Por tratar-se de um "terreno ainda não desbravado", nosso trabalho, analogamente, se assemelhava à abertura de trilhas. Com isso, seria preciso deixar marcadores pelos caminhos que criávamos, para indicar se deveriam, ou não, serem posteriormente seguidos. (BROCKINGTON, 2005, p.158)
}

Dessa forma, os "marcadores" ficaram definidos como os principais saberes necessários para estabelecer as ligações entre os vários conceitos constituintes de uma nova estrutura criada. Esses saberes também devem ser aqueles que, ao serem analisados sob a perspectiva das Regras da Transposição Didática, estarão mais adequados a serem transpostos e, principalmente, mais aptos a sobreviver nas salas de aula.

Assim, os "marcadores" atuariam como pontos de intersecção da nova estrutura gerada, permitindo, por exemplo, refazer os trajetos que unem os conceitos, bem como fornecer indícios sobre outros caminhos. Portanto, todos os novos conceitos inseridos na estrutura do novo saber, bem como as atividades, devem sempre se adequar a estes marcadores, aumentando as chances de sobrevivência no ambiente escolar, validando esses saberes segundo a Transposição Didática pela existência de um caráter terapêutico. 
Essa noção de marcador mostrou-se adequada para analisar seqüências didáticas, pois estruturam propostas de cursos. Contudo, os marcadores, além de demarcarem um caminho num campo em exploração, também explicitam atividades denominadas estruturadoras. Essa denominação é bastante adequada, afinal, quando combinadas caracterizam e estruturam um curso.

A noção de marcadores de Brockington (2005), então, evoluiu para a noção de "marcadores-estruturantes", utilizada no trabalho de Siqueira (2006) que os define da seguinte forma:

Usaremos então a noção de marcadores-estruturantes para definir aquelas atividades que serão os alicerces de nossa seqüência didática, que não podem ser modificadas, pois assim, corre-se o risco de descaracterizar o curso. (SIQUEIRA, 2006, p. 107)

Desse modo, podemos considerar que um curso é formado de atividadesestruturantes, onde estas atividades corresponderiam à parte rígida do curso, enquanto as demais corresponderiam à parte flexível. As modificações podem ocorrer somente na parte flexível, sem romper com os objetivos iniciais do curso.

Assim, temos os "marcadores-estruturantes", sendo materializados em atividades que julgamos serem essenciais para a estrutura do curso. Juntamente com eles, existem outras atividades que ajudam a lidar com as muitas dimensões do processo de ensino-aprendizagem da sala de aula, como a operacionalidade, a avaliação, a motivação, entre outros fatores. Estas, porém, não são pensadas como estruturadoras, porém são essenciais para o gerenciamento do cotidiano escolar. Dessa forma, são as atividades estruturantes juntamente com as demais atividades que fornecem uma solidez, confiança, validade moral e biológica ao curso proposto. Esses critérios determinam as chamadas "Regras da Transposição Didática", definidas por Astolfi (1997). Assim, como os "marcadores", os "marcadores-estruturantes" servem como ponto de intersecção entre os diversos elementos de um curso.

A idéia de se ter na estrutura do curso uma parte rígida, ou seja, uma parte não passível de ser modificada está ligada diretamente à física como saber de referência, onde os conceitos centrais presentes nessa estrutura denominados de Saber a Ensinar (curso) possam ser reconhecidos pelo Saber 
Sábio (saber produzido na física), como prevê a Transposição Didática. Além disso, é necessário que exista no curso uma outra parte, esta, porém, flexível, que pode ser alterada, pois está diretamente ligada ao sistema de ensino, onde é a figura do professor que precisa fazer adaptações do conteúdo, levando em conta o projeto escolar e o aprendizado dos seus alunos.

Assim, com a noção de "marcadores-estruturantes", diversos cursos podem ser gerados com uma estruturação coerente contemplando 0 conhecimento físico, ao mesmo tempo em que se insere uma seqüência didática adequada e lógica. Nessa construção o professor é um agente importante dentro de todo o processo, pois acaba atuando na Transposição Didática Interna.

\section{2 - Definindo os Marcadores-Estruturantes no curso de Física das Radiações}

Para a seqüência didática do curso de Física das Radiações, o uso dos marcadores-estruturantes permitiu definir os alicerces do curso, isto é, as atividades essenciais da proposta. A respectiva escolha está com base nas Regras da Transposição Didática, como será evidenciado nos próximos parágrafos, bem como, a apresentação desses marcadores.

O primeiro marcador-estruturante do curso de Física das Radiações foi escolhido para servir de porta de entrada do curso, no sentido de estar o mais próximo do cotidiano dos alunos e ainda possibilitar o desenvolvimento de todo o restante do mesmo a partir da sua inserção. Assim, a atividade que materializa o primeiro marcador-estruturante foi denominada de Análise da Chama de uma Vela. Inicia-se a seqüência com a discussão sobre as cores presentes na chama de uma vela, que é essencial para desvendar o espectro eletromagnético visível, a diferença de temperatura e energia que temos em cada região da chama, além de possibilitar a introdução da discussão sobre os fótons da luz.

Em princípio, a escolha dessa atividade como sendo a inicial da proposta, apareceu de uma forma bastante empírica, resultado da experiência do autor na elaboração da proposta, baseando-se nos objetivos a serem alcançados. Após a aplicação da atividade, e mais tarde com a análise da proposta como 
um todo, utilizando as regras da Transposição Didática, verificou-se grande êxito em sua execução, mostrando-se adequada a receber o título de primeiro marcador-estruturante, pois a atividade inicial permitiu dar um encadeamento lógico à seqüência, dando um caráter consensual, biológico e moral ao curso proposto. Além disso, permitiu a inserção de critérios para diferenciar as radiações presentes no espectro eletromagnético, critérios estes usados em toda a seqüência didática.

O segundo marcador-estruturante foi estabelecido como uma atividade que envolve os Raios- $\boldsymbol{X}$. Inicia-se a discussão sobre a descoberta dos raios- $\boldsymbol{X}$ e da radioatividade, sendo esta essencial para desvendar a estrutura da matéria, em particular do átomo. Apesar de outras investigações terem contribuído para a descoberta da estrutura atômica, foram as investigações e descobertas dos raios- $X$ e da radioatividade as precursoras para a abertura de portas para o desenvolvimento de novas áreas da física, como por exemplo, a Física Atômica e a Física de Partículas.

A Estabilidade Nuclear corresponde à atividade materializadora do terceiro marcador-estruturante. Esta atividade foi determinada como um novo marcador porque além de fazer uso de um modelo para explicar a estabilidade entre prótons e nêutrons no interior do núcleo atômico, também permite caracterizar os elementos radioativos (instáveis) presentes na tabela periódica e na natureza. É, assim, uma atividade introdutória ao estudo da radioatividade e das emissões radioativas emitidas por certos elementos, caracterizando uma outra classificação para as radiações, as chamadas radiações corpusculares.

Como conteúdo para o Ensino Médio, essa atividade apresenta para os alunos uma nova interação da natureza, a chamada interação forte. Ela acaba explicando de forma plausível a estabilidade do núcleo atômico, rompendo com a concepção de que partículas de mesmo sinal somente podem sofrer força do tipo coulombiana, de caráter repulsivo, além de permitir o estabelecimento de um critério para os quais alguns núcleos atômicos sejam estáveis, enquanto outros não o são.

Para finalizar a proposta, levando em conta os objetivos traçados inicialmente, conseguimos estabelecer o quarto marcador-estruturante e último do curso de Física das Radiações. Essa atividade ressalta o uso dos 
Detectores de Radiação, permitindo aos alunos o contato com mecanismos e dispositivos usados para detecção dos diversos tipos de radiações, sejam elas eletromagnéticas ou corpusculares. Como conteúdo para o Ensino Médio, essa atividade apresenta para os alunos o contador Geiger e os detectores de cintilação, além de apresentar o uso de câmaras de nuvens e bolhas, das emulsões fotográficas usadas para visualizar o rastro das radiações cósmicas muito utilizadas por César Lattes, além das radiografias que permitem identificar os efeitos dos raios- $X$ sobre a matéria, fornecendo imagens de seu interior.

Desde o início com o primeiro marcador, encaminhamos as discussões, atividades e o desenvolvimento do curso de Física das Radiações, de maneira a propiciar o fechamento do curso com a discussão sobre como detectar as radiações e os instrumentos disponíveis para fazer essa verificação. Assim, procuramos fornecer aos alunos a oportunidade de perceberem os detectores naturais existentes em nosso corpo, detectores estes adaptados para algumas radiações, como por exemplo, nossos olhos, adaptados a detectar a radiação visível, e a pele, responsável pela detecção da radiação infravermelha, além de apresentar a necessidade de outros detectores para "visualizar" as radiações invisíveis aos nossos sentidos.

Dessa forma, conseguimos definir os marcadores-estruturantes da proposta de ensino para a Física das Radiações, enumerando para cada bloco da proposta um marcador-estruturante, acreditando que além de explicitarem os principais elementos de uma proposta sobre o conteúdo radiações, ainda acabem fornecendo um encadeamento lógico e didático para a seqüência didática escolhida.

\section{3 - Os marcadores-estruturantes e sua análise}

Conforme a definição dos marcadores-estruturantes, iremos apresentar como se deu a análise dos mesmos utilizando as Regras da Transposição Didática, e como estas regras justificam a escolha desses marcadores. 


\subsection{1 - Primeiro Marcador-Estruturante}

Essa é uma atividade que dá início aos estudos da Física das Radiações. Para atrair a atenção e a curiosidade dos jovens, buscamos iniciar com uma atividade que estivesse bem próxima deles e que pudesse, de alguma forma, estar ligada ao seu cotidiano, buscando iniciar e encaminhar o curso através de uma análise fenomenológica. Por isso, a atividade que materializa o nosso primeiro marcador-estruturante é a atividade da análise da chama de uma vela.

O objetivo dessa atividade é o de propiciar um estudo do espectro eletromagnético à partir do espectro eletromagnético da luz visível, procurando estabelecer critérios para diferenciar as radiações presentes no espectro eletromagnético, critérios estes importantes para a análise de todas as radiações constituintes do espectro, permitindo caracterizá-las através de sua freqüência e energia. Como conteúdo para o Ensino Médio, a atividade possibilita levar aos alunos um maior conhecimento sobre a luz visível e a radiação eletromagnética como resultado da interação entre os campos elétrico e magnético, além de relacionar as características de uma radiação eletromagnética como, comprimento de onda, freqüência e energia, fornecendo instrumentos para os alunos enxergarem os objetos ao seu redor de uma forma mais apurada.

\subsubsection{1 - Descrição da atividade}

Na primeira parte da atividade, são entregues aos alunos uma vela, lápis de cor e uma folha de papel sulfite, sendo solicitado que eles acendam a vela e registrem na folha com o auxílio do lápis de cor o desenho da chama da vela com as respectivas cores presentes nela, além de destacarem, segundo seus conhecimentos, as regiões onde possivelmente a temperatura da chama é maior e menor (Figura 1). Essa atividade foi realizada em pequenos grupos de 2 ou 3 alunos, uma vez que o material utilizado era de fácil obtenção.

Em seguida, são levantadas, pelo professor, algumas questões que buscam nortear a discussão, tais como: quantas e quais são as cores presentes na chama de uma vela? Qual região da chama é mais quente? Qual 
região da chama é mais fria? Por quê? Como são produzidas essas colorações diferentes na chama? Todas as velas apresentam o mesmo tipo de chama? Por quê?

Essas questões serviram como motivação para iniciar a discussão sobre o espectro eletromagnético $e$ as ondas eletromagnéticas, tendo um grande retorno dos alunos que discutiram e expuseram suas opiniões e sensações sobre a chama da vela, além da possibilidade de exercício da observação e do questionamento. Vale ressaltar que muitos alunos desconheciam o motivo do aparecimento das diferentes colorações na chama de uma vela. Embora este fosse um fenômeno bastante corriqueiro, não thes havia ocorrido tais questionamentos. Sendo assim, para formalizar toda a discussão feita com os alunos, foram entregues os textos "Conhecendo as Radiações" e "Espectro Eletromagnético (Introdução)" para que eles pudessem ler a respeito do assunto e responder algumas questões que se encontravam no final do texto.
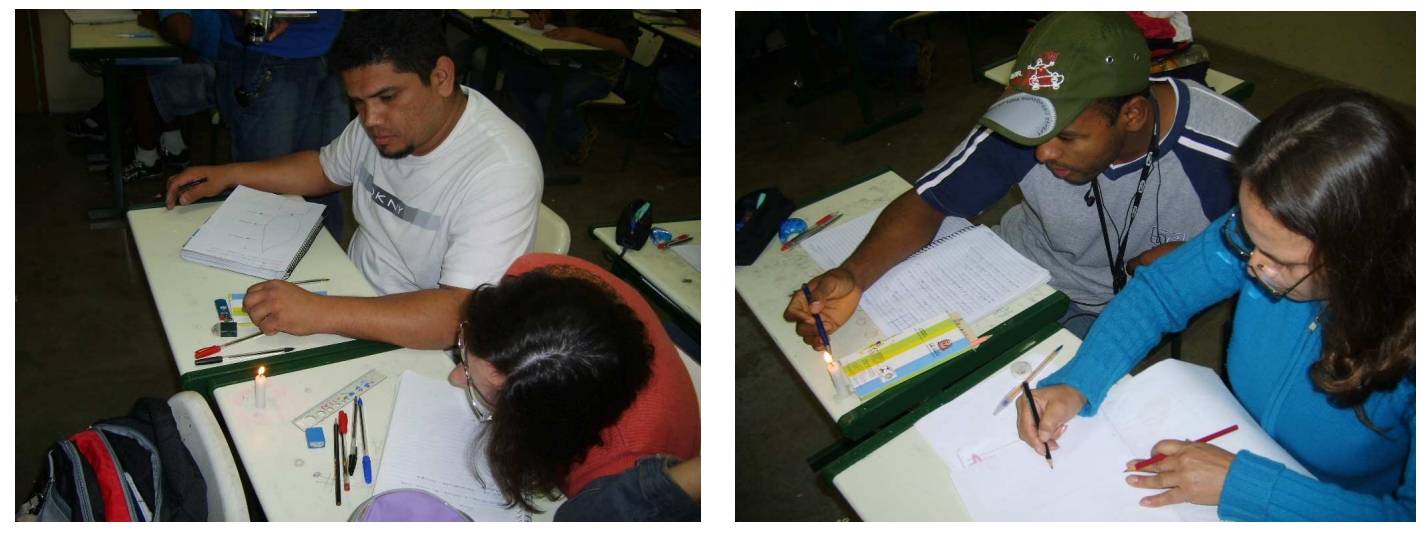

Figura 1 - Alunos analisando a chama de uma vela.

$\mathrm{Na}$ segunda parte da atividade, depois de conhecerem as radiações, sua classificação e o espectro eletromagnético, foi feita uma discussão sobre a forma como ocorrem as diferentes colorações que aparecem na chama, sendo necessária a discussão de alguns aspectos da química, como os diferentes tipos de combustão, e, finalmente, a introdução ao modelo atômico de Bohr e as transições que ocorrem entre os níveis de energia do átomo, realizadas pelos elétrons do material. Para isso, foram expostos os desenhos das chamas feitos pelos alunos para que eles percebessem elementos em comum nos 
desenhos, como por exemplo, as cores características de cada região (Figura 2).

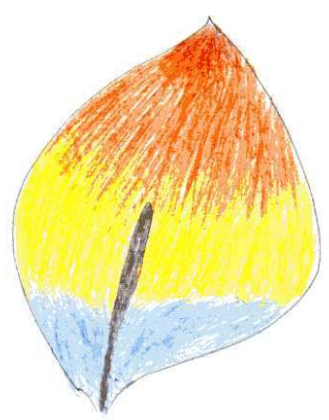

\begin{tabular}{|c|c|c|c|}
\hline côkes & HEMPEAAlOAS & ENEnGIA & \\
\hline AZV & BA.IXA & $\mu \in$ NOR & $\begin{array}{l}\text { TEMPEnituna Ratixa } \\
\text { to PreunecenolOCN }\end{array}$ \\
\hline$A M A \cap \in C A$ & MODERADA & $M \in$ Dis & 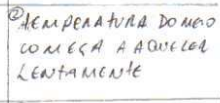 \\
\hline$\angle A M A N$ JA & Al $\times$ A & $M+10 R$ & $\begin{array}{l}\text { (3) A leM PEA AWRA } \\
\text { COMECA A SE } \\
\text { ESQVENTAR }\end{array}$ \\
\hline
\end{tabular}

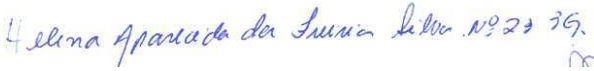
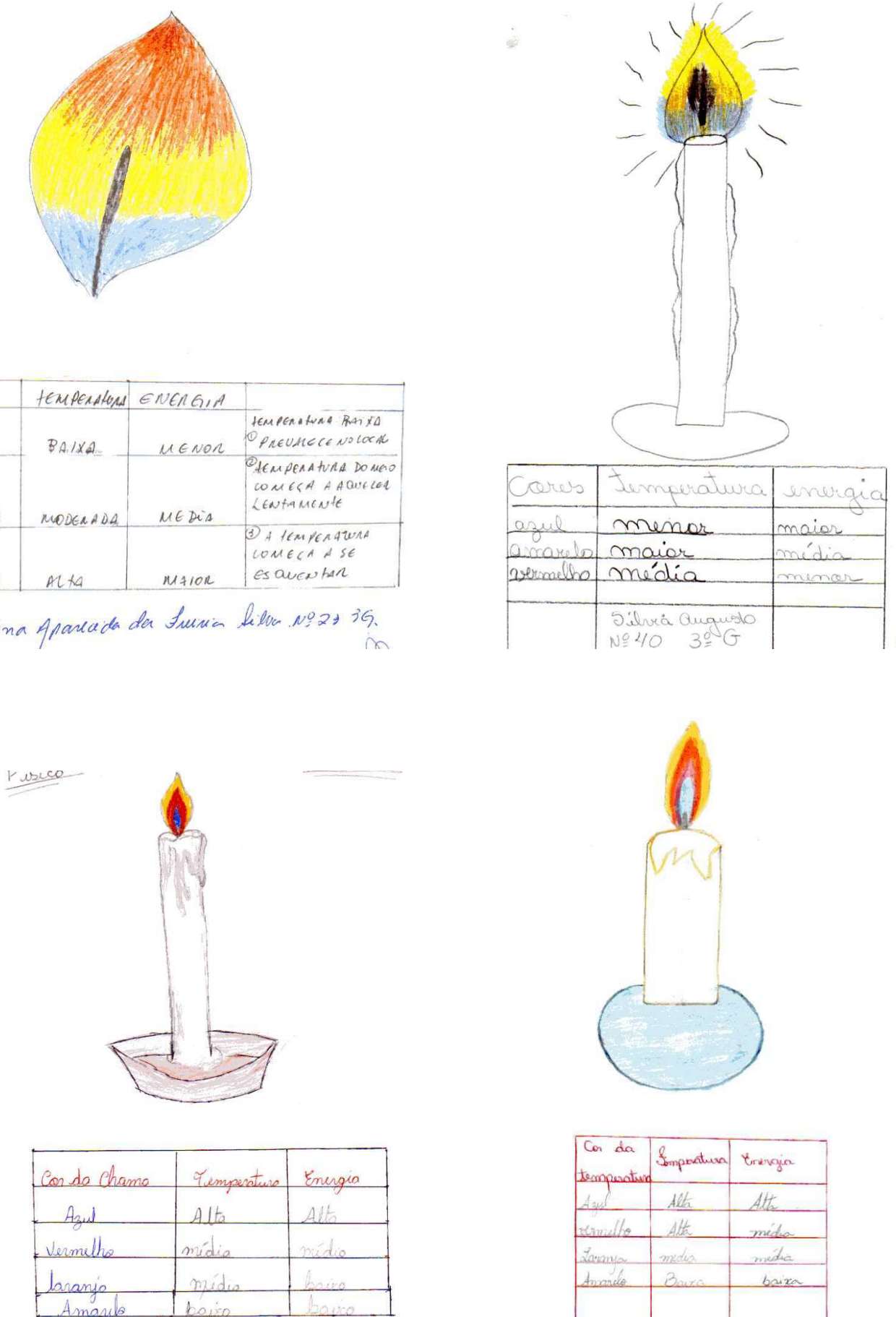

Nomu: Pauba dérgis F. da Silva no41 sirie $3^{\circ} 64$

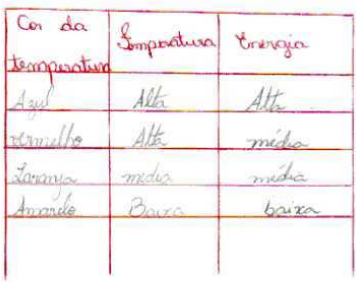

Figura 2 - Desenhos realizados pelos alunos na atividade com a vela.

Essa segunda parte da atividade tem como objetivo apresentar uma das formas como os átomos de um material podem emitir luz visível, ou seja, radiação eletromagnética, do ponto de vista da Física Moderna, sendo então a 
necessária inserção do modelo atômico de Bohr e a sua respectiva discussão para fazer essa justificativa. Percebemos, então, que essa parte da atividade busca apresentar a necessidade de elementos da Física Moderna, ou seja, de elementos de uma Física mais Contemporânea para justificar um fenômeno extremamente simples de se criar e observar, porém muito intrigante como ficou notório pela participação e discussão dos alunos, que é a chama de uma vela.

\subsubsection{2 - A análise do primeiro marcador-estruturante}

Essa atividade teve como principal objetivo apresentar as radiações, suas diferentes formas, seu processo de produção, além de fornecer ao aluno o contato com o espectro eletromagnético, um elemento dos mais importantes para a classificação das radiações quanto as suas características como comprimento de onda, frequência e energia, além de possibilitar a introdução de aspectos da Física Moderna como o modelo atômico de Bohr, modelo este importante para o entendimento dos espectros discretos dos elementos na natureza e dos espectros contínuos como o de algumas lâmpadas.

O desenvolvimento da atividade foi feito de forma aberta e dinâmica, deixando os alunos bem à vontade para que investigassem e discutissem as diferentes colorações presentes na chama de uma vela, gerando um grande interesse e entusiasmo entre eles em trabalhar um objeto tão próximo do seu cotidiano, mas ao mesmo incompreendido em sua essência.

Assim, conseguimos notar que 0 ambiente da aula foi tranqüilo $e$ envolvente, não havendo problemas com disciplina ou apatia dos alunos durante o transcorrer da aula. Esses foram aspectos interessantes na aula, em momento algum notamos que os alunos estavam focados em outras coisas que não fosse a atividade proposta. Todos os 35 alunos participaram ativamente da análise da chama de uma vela, procurando identificar as questões que 0 professor havia proposto no início da atividade, conforme ilustra as transcrições a seguir:

\begin{tabular}{|c|c|c|}
\hline Tempo & Transcrição & Gestos \\
\hline & "Pessoal, vocês já olharam para a & \\
\hline
\end{tabular}




\begin{tabular}{|c|c|}
\hline $\begin{array}{c}\text { V(Prof.) } \\
1^{\prime} 42^{\prime \prime}\end{array}$ & $\begin{array}{l}\text { chama de uma vela? Não? Vocês } \\
\text { deverão anotar quantas cores } \\
\text { diferentes estão presentes na chama } \\
\text { de uma vela e desenhar na folha a } \\
\text { chama com suas cores." }\end{array}$ \\
\hline
\end{tabular}

Esse foi o primeiro ponto que forneceu indício da operacionalidade de nosso marcador-estruturante. Conforme foi discutido no capítulo $2^{1}$, a operacionalidade está ligada diretamente à capacidade que o novo saber tem em gerar algum tipo de questão ou tarefa que possa ser avaliada pelo professor e que busque a conceituação do saber. Assim, a questão proposta pelo professor teve o intuito de gerar uma tarefa para os alunos, para que ele posteriormente fizesse uma conceituação formal do saber que estava sendo discutido na atividade.

A observação das chamas e o seu registro (desenho) também foi o ponto de destaque da atividade. Entre o início e o término dos registros, ela durou cerca de 25 minutos, dentro do tempo previsto no planejamento da aula. Além disso, os alunos não mostraram qualquer dificuldade em elaborar o desenho da chama, apenas questionando detalhes como se desenhariam o pavio ou não, sendo que os critérios usados para fazer a verificação de qual região da chama seria a mais quente é que mais "incendiaram" as discussões, como mostram o diálogo ${ }^{2}$ e a figura 3 a seguir:

\begin{tabular}{|c|c|c|}
\hline Tempo & Transcrição & Gestos \\
\hline $\begin{array}{c}\mathrm{V}\left(\mathrm{A}_{1}\right) \\
16^{\prime} 12^{\prime \prime}\end{array}$ & $\begin{array}{l}\text { "Como eu vou saber qual parte é a } \\
\text { mais quente? E se eu colocar a } \\
\text { lapiseira aqui, o que acontece?" }\end{array}$ & $\begin{array}{l}\text { Encosta a lapiseira na } \\
\text { chama da vela. }\end{array}$ \\
\hline $\begin{array}{c}V\left(A_{2}\right) \\
16^{\prime} 17^{\prime \prime}\end{array}$ & "E aí?" & \\
\hline $\begin{array}{l}\mathrm{V}\left(\mathrm{A}_{1}\right) \\
16^{\prime} 19^{\prime \prime}\end{array}$ & "Não está acontecendo nada!" & $\begin{array}{l}\text { Chama a atenção da } \\
\text { amiga com a qual está }\end{array}$ \\
\hline
\end{tabular}

\footnotetext{
${ }_{2}^{1}$ Página 43 , referente à sobrevivência do saber.

2 Iremos adotar durante a transcrição dos diálogos a seguinte notação para as falas dos alunos: $\mathbf{V}$ representa que a transcrição é de vídeo, $\mathbf{Q}$ representa transcrição do questionário, $\mathbf{A}$ representa aluno e $\mathbf{x}$ o aparecimento do aluno na filmagem, que conforme aparecem, recebem um número. Já o questionário, eles receberam letras do alfabeto, em uma ordem aleatória.
} 


\begin{tabular}{|c|l|l|}
\hline & & fazendo a atividade. \\
\hline $\mathbf{V}\left(\mathbf{A}_{2}\right)$ & "E agora? O que a gente faz?" & \\
\hline $\mathbf{1 6} \mathbf{2 2} "$ & & \\
\hline
\end{tabular}

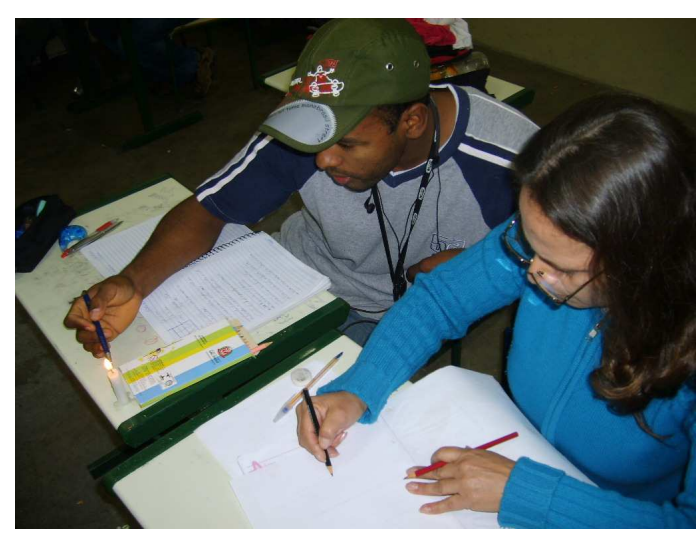

Figura 3 - Aluno verificando as regiões presentes na chama da vela.

Em outro momento, notamos mais uma discussão gerada pela não concordância quanto ao critério de como identificar a parte da chama que é mais quente, mostrando mais uma vez que a atividade proposta motivou a participação e envolvimento dos alunos, como mostram o diálogo e a figura 4 a seguir:

\begin{tabular}{|c|c|c|}
\hline Tempo & Transcrição & Gestos \\
\hline $\begin{array}{l}V\left(A_{3}\right) \\
19^{\prime} 35^{\prime \prime}\end{array}$ & $\begin{array}{l}\text { "E se a gente colocar um pedaço de } \\
\text { papel perto da vela? O que } \\
\text { acontece?" }\end{array}$ & $\begin{array}{l}\text { Aproxima o pedaço de } \\
\text { papel da chama da vela. }\end{array}$ \\
\hline $\begin{array}{l}V\left(A_{4}\right) \\
19^{\prime} 40^{\prime \prime}\end{array}$ & "Vai queimar a folha, não é!" & \\
\hline $\begin{array}{l}V\left(A_{3}\right) \\
19^{\prime} 43^{\prime \prime}\end{array}$ & $\begin{array}{l}\text { "Mas vai queimar mais rápido onde } \\
\text { for mais quente!" }\end{array}$ & $\begin{array}{l}\text { Tira rapidamente } \\
\text { pedaço de folha que está } \\
\text { começando a queimar. }\end{array}$ \\
\hline
\end{tabular}



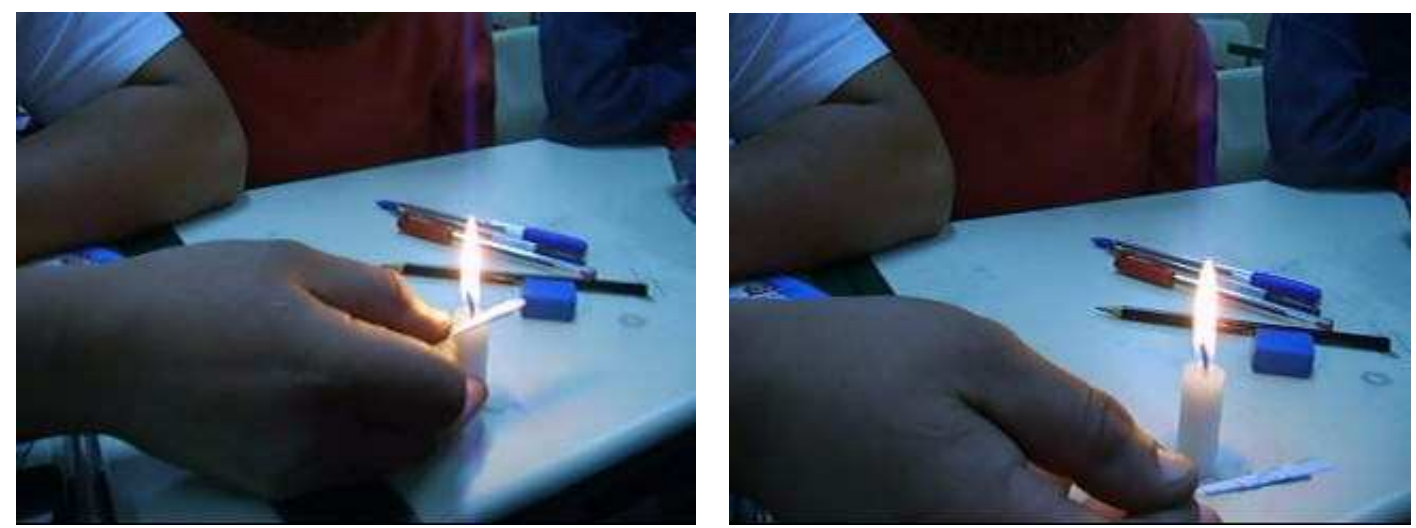

Figura 4 - Aluno executando seu teste do papel junto à chama da vela.

Esse mesmo grupo de alunos que confiaram no "teste do papel", nome dado por eles a essa técnica posteriormente, conseguiu segundo suas hipóteses, afirmar que a região azulada da chama era a que tinha a maior temperatura, e, portanto, era a que tinha maior energia, afinal era nessa região da chama onde o papel queimava mais rapidamente, conforme aponta o diálogo a seguir:

\begin{tabular}{|c|c|c|}
\hline Tempo & Transcrição & Gestos \\
\hline $\begin{array}{l}V\left(A_{3}\right) \\
22^{\prime} 10^{\prime \prime}\end{array}$ & $\begin{array}{l}\text { "Veja só, não disse, aqui vai mais } \\
\text { rápido!" }\end{array}$ & $\begin{array}{l}\text { Aponta o dedo para o } \\
\text { pedaço de papel próximo } \\
\text { à região azulada da } \\
\text { chama da vela. }\end{array}$ \\
\hline $\begin{array}{l}V\left(A_{4}\right) \\
22^{\prime} 13^{\prime \prime}\end{array}$ & "Não acredito! Faz de novo." & \\
\hline $\begin{array}{l}V\left(A_{3}\right) \\
22^{\prime} 15^{\prime \prime}\end{array}$ & “Então, presta atenção!” & $\begin{array}{l}\text { Tira rapidamente } 0 \\
\text { pedaço de folha que está } \\
\text { começando a queimar. }\end{array}$ \\
\hline
\end{tabular}

Para encaminhar todo o desenvolvimento dessa atividade, foi entregue, no início, um roteiro que serviu como guia para a atividade. Esse roteiro continha questões, que foram reforçadas pelo professor antes deles receberem os materiais da atividade, fazendo com que os alunos fossem guiados pelas perguntas para análise e discussões. Ao final da atividade, o professor buscou levantar novamente as questões para iniciar a discussão sobre a temperatura 
da chama da vela, o que trouxe em evidência a relação da atividade com objetos do cotidiano do aluno, como mostra o trecho a seguir:

\begin{tabular}{|c|c|c|}
\hline Tempo & Transcrição & Gestos \\
\hline $\begin{array}{l}\text { V(Prof.) } \\
25^{\prime} 40^{\prime \prime}\end{array}$ & $\begin{array}{l}\text { "E aí? O que vocês concluíram? } \\
\text { Qual parte da chama é mais } \\
\text { quente?" }\end{array}$ & \\
\hline $\begin{array}{l}V\left(A_{3}\right) \\
25^{\prime} 50^{\prime \prime}\end{array}$ & "É a azul." & \\
\hline $\begin{array}{l}\text { V(Prof.) } \\
25^{\prime} 55^{\prime \prime}\end{array}$ & $\begin{array}{l}\text { "Quem mais concorda? Ou } \\
\text { discorda?" }\end{array}$ & \\
\hline $\begin{array}{l}V\left(A_{6}\right) \\
26^{\prime} 01^{\prime \prime}\end{array}$ & "Não dá pra saber desse jeito..." & \\
\hline $\begin{array}{l}\text { V(Prof.) } \\
26^{\prime} 03^{\prime \prime}:\end{array}$ & $\begin{array}{l}\text { "Afinal, dá ou não? Quem acha que é } \\
\text { outra região?" }\end{array}$ & \\
\hline $\begin{array}{l}V\left(A_{7}\right) \\
26^{\prime} 10^{\prime \prime}\end{array}$ & "Eu também acho que é o azul." & \\
\hline $\begin{array}{l}V\left(A_{8}\right) \\
26^{\prime} 15^{\prime \prime}\end{array}$ & $\begin{array}{l}\text { "Não é igual à chama do fogão? Tá, } \\
\text { mas o por que eu não sei!" }\end{array}$ & \\
\hline
\end{tabular}

Isso indica que apesar de ter tido um interesse muito grande dos alunos pela análise da chama, em nenhum momento as questões colocadas inicialmente foram deixadas de lado, reforçando o fato de que a atividade foi executada sem problemas pelos alunos.

Esses pontos que acabamos de apresentar sobre a atividade da chama de uma vela, reafirmam o caráter da operacionalidade, indicando que essa aula iniciada com a atividade é aplicável em sala de aula, tendo sido validada pelos alunos que se interessaram e participaram muito. Isso reforça a idéia de que é possível criar uma atividade, elaborar questões acerca das radiações e do 
espectro eletromagnético e de fenômenos ligados a ele, possibilitando ao aluno uma inferência aos objetos do seu cotidiano.

É notória também a presença do caráter da terapêutica durante alguns momentos da aula, o que pontua o sucesso da atividade. Entre esses momentos, podemos citar aquele onde o professor obteve o sucesso em gerenciar o desenvolvimento da atividade, mostrando que não teve problemas em manter a atenção dos alunos para o objetivo da aula, mesmo quando estava explicando o conteúdo, permanecendo, aproximadamente, 25 minutos, formalizando a discussão feita com a atividade, sem que a turma tenha se dispersado.

Dessa forma, podemos considerar que do ponto de vista do planejamento da aula e da atividade, tivemos outra manifestação da terapêutica, pois a aula havia sido planejada para que acontecessem três momentos:

- Primeiramente a apresentação das questões para que estas servissem de orientação para a execução da atividade;

- Em seguida, a própria aplicação da atividade;

- E, finalmente, o fechamento com a devida formalização dos conceitos que foram trabalhados na atividade.

Analisando as aulas, conseguimos verificar que esses três momentos aconteceram conforme o programado, o que nos aponta o sucesso que obteve o professor na condução das aulas. Assim, para cada momento previsto, verificamos os seguintes tempos para sua execução:

- 1 momento: apresentação das questões de orientação da atividade: teve uma duração de 10 minutos;

- 20 momento: aplicação da atividade: teve uma duração de 35 minutos;

- 3o momento: discussão e formalização dos conceitos: teve uma duração de 35 minutos.

No planejamento estava previsto o tempo de desenvolvimento de toda a aula com a atividade que também nos forneceu indícios da terapêutica. A aula e a atividade haviam sido programadas para serem trabalhadas em duas aulas, totalizando aproximadamente 90 minutos. Durante a aplicação o professor soube gerenciar bem esse tempo, não deixando a aula nem muito corrida, nem 
muito lenta, utilizando de forma adequada o tempo das aulas para fazer o fechamento da atividade. Ainda é perceptível que restaram 10 minutos do tempo total de 90 minutos correspondente às aulas, o que é totalmente aceitável quando pensamos na administração de tarefas como a organização da sala, entre outras rotinas.

Temos uma indicação do relativo sucesso que essa atividade apresentou na sala de aula, levando, assim, à terapêutica. Isso refletiu muito sobre as discussões levantadas em sala de aula, mostrando que essa atividade pode permanecer em sala, pois ela motiva a discussão entre os alunos e também os instiga a buscar um conhecimento do tópico apresentado, conforme mostra a descrição a seguir:

$\mathbf{Q}\left(\mathbf{A}_{\mathrm{L}}\right)$ : "Nunca parei para reparar nesse problema da cor da chama de uma vela. Achei interessante entender o seu funcionamento!"

Embora a atividade tenha sido aplicada para um pequeno grupo de estudantes, acreditamos que com outras aplicações dessa atividade em diferentes salas de aula e para diferentes grupos de alunos, não necessariamente da modalidade EJA, poderemos garantir o sucesso da atividade e a sua perfeita exeqüibilidade. Outro detalhe que não pode ser ignorado é o fato de que com essa simples atividade, conseguimos melhorar o entendimento dos alunos sobre o objeto estudado, levando à criação de um objeto didático que auxiliou no aprendizado dos alunos. Esse fato configura a criatividade didática, inerente a todo processo de produção de saber escolar, o que fica evidenciado na transcrição abaixo:

\begin{tabular}{|c|l|l|}
\hline Tempo & \multicolumn{1}{|c|}{ Transcrição } & Gestos \\
\hline $\mathbf{V}($ Prof.) & "Pessoal, em que posições você & \\
\hline $\mathbf{6}\left(\mathbf{A}_{1}\right)$ & $\begin{array}{l}\text { chegaram? Onde a temperatura é } \\
\text { maior?" }\end{array}$ & \\
$\mathbf{6 3} \mathbf{0 1}^{\prime \prime}$ & "É em baixo no azul." & \\
\hline $\mathbf{V}\left(\mathbf{A}_{\mathbf{2}}\right)$ & "É no amarelo." & \\
\hline
\end{tabular}




\begin{tabular}{|c|c|c|}
\hline $63^{\prime} 03^{\prime \prime}$ & & \\
\hline $\begin{array}{l}\mathrm{V}\left(\mathrm{A}_{3}\right) \\
63^{\prime} 05^{\prime \prime}\end{array}$ & "É no laranja." & \\
\hline $\begin{array}{l}\text { V(Prof.) } \\
63^{\prime} 07^{\prime \prime}\end{array}$ & "Afinal, qual é a mais quente?" & \\
\hline $\begin{array}{l}\mathrm{V}\left(\mathrm{A}_{4}\right) \\
63^{\prime} 09^{\prime \prime}\end{array}$ & "E também acho que é a azul!" & \\
\hline $\begin{array}{l}\text { V(Prof.) } \\
63^{\prime} 12^{\prime \prime}\end{array}$ & $\begin{array}{l}\text { "Por que, então, a região azulada é a } \\
\text { mais quente? Será que o espectro } \\
\text { eletromagnético ajuda a responder? } \\
\text { Dêem uma olhada no espectro } \\
\text { eletromagnético." }\end{array}$ & $\begin{array}{l}\text { O professor mostra o } \\
\text { espectro eletromagnético } \\
\text { presente no texto aos } \\
\text { alunos. }\end{array}$ \\
\hline $\begin{array}{l}\text { V(Prof.) } \\
63^{\prime} 16^{\prime \prime}\end{array}$ & $\begin{array}{l}\text { "Em que parte se encontra o azul no } \\
\text { espectro?" }\end{array}$ & \\
\hline $\begin{array}{l}\text { V(alunos) } \\
63^{\prime} 18^{\prime \prime}\end{array}$ & “Da luz!” & \\
\hline $\begin{array}{l}\text { V(Prof.) } \\
63^{\prime} 21^{\prime \prime}\end{array}$ & $\begin{array}{l}\text { "Então tem maior ou menor energia } \\
\text { que, por exemplo, a luz amarela?" }\end{array}$ & \\
\hline $\begin{array}{l}\text { V(alunos) } \\
63^{\prime} 25^{\prime \prime}\end{array}$ & "Maior!" & \\
\hline V(Prof.) & "Por quê?" & \\
\hline
\end{tabular}




\begin{tabular}{|c|c|c|}
\hline $63^{\prime} 27^{\prime \prime}$ & & \\
\hline $\begin{array}{l}\mathrm{V}\left(\mathrm{A}_{3}\right) \\
63^{\prime} 30^{\prime \prime}\end{array}$ & "Tem a ver com a onda!" & \\
\hline $\begin{array}{l}\text { V(Prof.) } \\
63^{\prime} 33^{\prime \prime}\end{array}$ & "Por quê?" & \\
\hline $\begin{array}{l}\mathrm{V}\left(\mathrm{A}_{3}\right) \\
63^{\prime} 35^{\prime \prime}\end{array}$ & "A energia da onda!" & \\
\hline $\begin{array}{l}\text { V(Prof.) } \\
63^{\prime} 38^{\prime \prime}\end{array}$ & $\begin{array}{l}\text { "Vamos lembrar a relação entre } \\
\text { freqüência e energia." }\end{array}$ & 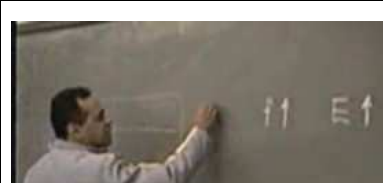 \\
\hline $\begin{array}{l}\mathrm{V}\left(\mathrm{A}_{3}\right) \\
63^{\prime} 45^{\prime \prime}\end{array}$ & $\begin{array}{l}\text { "Ah professor, lembrei da aula da } \\
\text { mola que você trouxe!" }\end{array}$ & \\
\hline
\end{tabular}

Portanto, percebemos que a criatividade didática permitiu fazer uma discussão sobre a maneira como é produzida a chama, além de obrigar a encontrarmos uma justificativa plausível para as diferentes colorações presentes na chama, o que se deu pela introdução do modelo atômico de Bohr, sem levar em consideração que a partir disso surgiram outros questionamentos referentes a outras chamas, como por exemplo, a chama muito azulada do maçarico e da boca do fogão. Assim, conseguimos elaborar questões na própria atividade e conectá-las com os textos que foram entregues em seguida, com o objetivo de dar uma sistematização à discussão e, a partir daí, gerar novas questões para serem respondidas por eles.

Podemos então perceber o grande potencial que esse tópico possui em criar questões qualitativas para a discussão e o entendimento do espectro eletromagnético, justificando assim sua presença na sala de aula. Assim, fica 
em destaque a operacionalidade ${ }^{3}$, onde foi possível transformar esse saber em exercícios e problemas. Diante disso, podemos concluir que a atividade auxiliou os alunos a compreenderem melhor o processo de produção da luz na chama de uma vela, bem como a sua conexão com o espectro eletromagnético, mostrando que esse marcador apresenta segue uma regra essencial no processo da Transposição Didática que é o de tornar um conceito mais compreensível ${ }^{4}$.

Finalmente, do ponto de vista escolar e do currículo de física, a discussão sobre o espectro eletromagnético se faz necessária uma vez que as radiações eletromagnéticas estão presentes em nosso cotidiano, sendo que a todo momento estamos interagindo com elas, seja através das ondas da luz visível, seja através das ondas de calor (infravermelho), mas muitas vezes passando despercebidas aos nossos sentidos, pois para grande parte das pessoas tal conhecimento não existe, cabendo à escola fornecer o subsídio para que os estudantes tenham um conhecimento maior sobre os aspectos das radiações e sua importância em nossas vidas. Além disso, toda essa discussão promove a apresentação de conceitos de uma forma científica, fugindo ao nível empírico e popular, propiciando um conhecimento mais correto dos fenômenos físicos. Assim, justifica-se sua presença em sala de aula por trazer uma atualização moral, por se tratar de um tópico importante a ser discutido em sala de aula e presente no currículo de física do Ensino Médio, levando a uma atualização do saber escolar ${ }^{5}$.

Um elemento que nos permite referendar a atualização do saber escolar, conforme mencionado anteriormente, aparece quando analisamos 0 questionário aplicado ao término do curso, onde ao questionarmos os alunos sobre qual atividade eles mais lembravam, ou mesmo, mais gostaram, e quais os motivos para essa escolha, eles acabaram fornecendo respostas como:

$\mathbf{Q}\left(\mathbf{A}_{\mathbf{x}}\right)$ : "A atividade da chama, porque eu não sabia que tinha tanta coisa por traz de uma simples vela. Eu achava que era algo tão simples."

\footnotetext{
${ }^{3}$ Regra IV.

${ }^{4}$ Regra V.

${ }^{5}$ Regra II.
} 
$Q\left(A_{w}\right):$ "Aquela da vela, por que trouxe muita discussão e idéias interessantes."

Também podemos afirmar que a atividade permitiu articular o saber novo com 0 antigo ${ }^{6}$, promovendo uma maior credibilidade para esse novo saber, principalmente quando se faz referência à combustão (Física Clássica) e à liberação de energia luminosa, explicada com conceitos da Física Moderna. Isso pode ser confirmado quando Astolfi (1997) destaca que alguns conteúdos são escolhidos "porque permitem uma articulação mais satisfatória entre 0 novo que se tenta introduzir, e o velho já provado no sistema (...)". Esse aspecto pode ser visto na transcrição a seguir:

\begin{tabular}{|c|c|c|}
\hline Tempo & Transcrição & Gestos \\
\hline $\begin{array}{l}\text { V(Prof.) } \\
32^{\prime} 02^{\prime \prime}\end{array}$ & $\begin{array}{l}\text { "E agora, a queima da vela é tão } \\
\text { simples como aparenta?" }\end{array}$ & \\
\hline $\begin{array}{l}V\left(A_{6}\right) \\
322^{\prime} 06^{\prime \prime}\end{array}$ & $\begin{array}{l}\text { "Eu achei que era, mas olhando } \\
\text { direito é muita coisa além da simples } \\
\text { queima do pavio. Antes a gente só } \\
\text { falava em queima e calor, aqui foi } \\
\text { mais longe!" }\end{array}$ & \\
\hline
\end{tabular}

Portanto, após analisar o questionário ${ }^{7}$ que elaboramos para tentar obter algumas impressões sobre a estrutura do curso e as atividades, foi possível confirmar aquilo que durante a gravação da aula sobre essa atividade já havia ficado em evidência, ou seja, o entusiasmo que a atividade gerou nos alunos, permitindo inferir que foi certa a escolha da mesma como porta de entrada ao curso de Física das Radiações. Além disso, as respostas fornecidas pelos alunos ainda reforçaram o caráter da terapêutica e da operacionalidade, indicando que essa atividade obteve um bom desempenho entre eles, possibilitando afirmamos que com ela os objetivos foram alcançados.

\footnotetext{
${ }^{6}$ Regra III.

${ }^{7}$ Encontra-se nos anexos.
} 


\subsection{2 - Segundo Marcador-Estruturante}

Definimos como atividade materializadora do segundo marcadorestruturante do curso a atividade que utiliza os raios- $\boldsymbol{X}$. Essa atividade dá uma continuidade ao estudo das radiações eletromagnéticas e inicia-se com a discussão sobre a descoberta dos raios- $X$ e da radioatividade, sendo esta essencial para desvendar a estrutura da matéria, em particular do átomo. Assim, buscamos iniciar esta atividade com algo que estivesse bem próximo deles e do seu cotidiano, optando, portanto, pelo uso de radiografias.

O objetivo dessa atividade é levar ao aluno a compreensão do processo de produção dos raios- $X$, das radiografias e das diferenças entre as tonalidades presentes nelas, como conseqüência da absorção de diferentes materiais de densidades distintas. Para isso procuramos fazer com que o aluno entenda a natureza dos raios- $X$, como ocorreu a sua descoberta, quais foram as conseqüências dela para o meio científico, bem como instigá-lo a relacionarem os raios- $X$ a uma forma de radiação eletromagnética com uma energia muito maior que a presente na luz visível.

\subsubsection{1 - Descrição da atividade}

Inicialmente são entregues aos alunos radiografias para que eles possam investigá-las e destacar características que chamaram a sua atenção, como por exemplo, forma, nitidez, partes do corpo a que pertencem, e se podem identificar algum tipo de fratura, presença de corpos estranhos como pinos, entre outros detalhes (figura 5). Nesse ponto, a atividade é feita com uma primeira discussão em grupos de 2 ou 3 alunos.

Em seguida são levantadas, pelo professor, algumas questões que buscam nortear a discussão, tais como: qual a radiografia que mais chamou a atenção? Por quê? Por que existem regiões mais claras e mais escuras? Por que algumas radiografias apresentam nitidez melhor? Como são produzidas as radiografias? Quem causou o aparecimento dessas imagens nas radiografias?

Essas questões serviram como motivação para iniciar a discussão sobre os raios- $X$, as radiografias e o uso de uma forma de radiação eletromagnética, tendo um grande retorno dos alunos que discutiram e expuseram suas opiniões 
e sensações sobre as radiografias. O que foi interessante constatar era que, embora eles conhecessem a radiografia e os raios- $X$, não tinham a menor idéia como eram produzidos os raios- $X$ e nem as radiografias. Para formalizar toda a discussão feita com os alunos, foi entregue o texto "Vendo através da pele: a descoberta dos raios- $X^{8}$ " para que eles pudessem ler a respeito do assunto e responder algumas questões que se encontravam no final do texto.

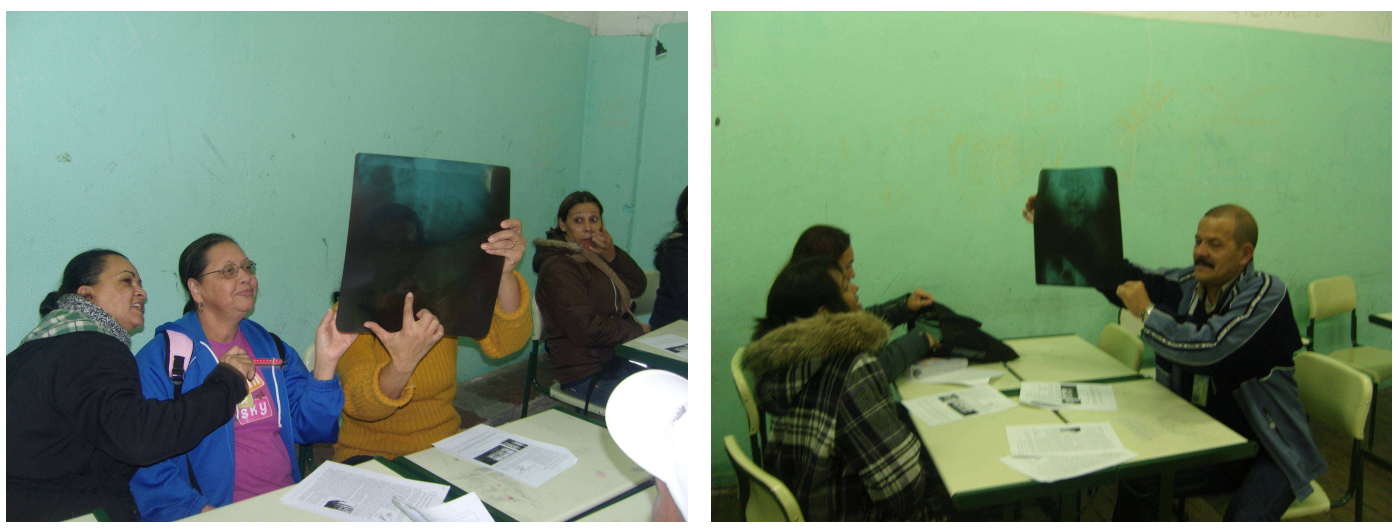

Figura 5 - Alunos observam as radiografias.

\subsubsection{2 - A análise do segundo marcador-estruturante}

O principal objetivo dessa atividade é o de apresentar o processo dos raios-X e o modo como ocorre à produção das imagens por ação deles nas chapas radiográficas, buscando, também, salientar os principais aspectos referentes aos raios- $X$, como produção, detecção e absorção em alguns materiais. Também teve como objetivo o de apresentar os raios- $X$ como uma forma de radiação eletromagnética muito mais energética que a luz visível, capaz de atravessar nosso corpo e produzir imagens em uma radiografia. Também não foi deixado de lado o contexto histórico, que mostra como os raios-X contribuíram para a mudança na concepção de átomo, para a evolução do modelo atômico e para o desenvolvimento de novas áreas na Física.

O desenvolvimento da atividade foi realizada de uma maneira bastante dinâmica e aberta, deixando os alunos à vontade para que investigassem e discutissem as radiografias, gerando um grande interesse e entusiasmo entre eles em trabalhar com um objeto tão comum em sua vida diária, mas

\footnotetext{
${ }^{8}$ Texto escrito originalmente por Maxwell Siqueira (2006) e presente nos anexos da sua dissertação sobre Física das Partículas.
} 
aparentemente de difícil compreensão. Dessa forma, conseguimos notar que o ambiente da aula foi tranqüilo e envolvente, não havendo problemas com disciplina ou apatia dos alunos durante o transcorrer da aula. Esses foram aspectos marcantes na aula, em momento algum notamos que os alunos estavam focados em outras coisas que não fosse a atividade. Constatamos que todos os alunos presentes (35 alunos), participaram ativamente da investigação sobre as imagens nas radiografias, procurando identificar as questões que o professor havia proposto no início da atividade, como pode ser evidenciado na transcrição abaixo:

\begin{tabular}{|c|c|c|}
\hline Tempo & Transcrição & Gestos \\
\hline $\begin{array}{c}\text { V(Prof) } \\
0^{\prime} 57^{\prime \prime}\end{array}$ & $\begin{array}{l}\text { "Pessoal, a tarefa de vocês é bem } \\
\text { simples, vocês deverão anotar os } \\
\text { aspectos que vocês julgarem } \\
\text { interessantes e que chamarem a } \\
\text { atenção de vocês nas radiografias." }\end{array}$ & \\
\hline
\end{tabular}

Encontramos aqui o primeiro indício de uso da operacionalidade do nosso marcador, uma vez que a operacionalidade está ligada diretamente à capacidade que o novo saber tem em gerar algum tipo de questão ou tarefa que possa ser avaliado pelo professor e que busque a conceituação do saber. Assim, a questão proposta pelo professor teve o intuito de gerar uma tarefa para os alunos, para que ele posteriormente fizesse uma conceituação formal do saber que estava sendo discutido na atividade.

A manipulação das radiografias também foi o ponto alto da atividade. Ela durou cerca de 25 minutos, dentro do tempo previsto no planejamento da aula. Além disso, os alunos não mostraram qualquer dificuldade em manuseá-las, fazendo de maneira correta, levantando-as em direção à luz para realçar bem as diferenças de tonalidades. Durante a análise das radiografias, os alunos conseguiram identificar objetos diferentes, como um pino presente em uma delas, como mostra o diálogo a seguir:

\begin{tabular}{|l|l|l|}
\hline Tempo & \multicolumn{1}{|c|}{ Transcrição } & \multicolumn{1}{|c|}{ Gestos } \\
\hline $\mathbf{V}\left(\mathbf{A}_{\mathbf{1}}\right):$ & "O que é isso? Parece um pino!" & $\begin{array}{l}\text { Aponta com o dedo na } \\
\text { radiografia. }\end{array}$ \\
\hline $\mathbf{5} \mathbf{5 7}^{\prime \prime}$ & & radion \\
\hline
\end{tabular}




\begin{tabular}{|l|l|l|}
\hline & & \\
& & \\
\hline $\mathbf{V}\left(\mathbf{A}_{2}\right):$ & "Como você sabe?" & \\
\hline $\mathbf{6}^{\prime} \mathbf{0 2}$ " & & \\
\hline $\mathbf{V}\left(\mathbf{A}_{1}\right):$ & "Meu irmão já caiu de moto e teve & Aponta a região onde \\
$\mathbf{6}^{\prime} \mathbf{0 7} "$ & que colocar um desses na perna!" & aparece na radiografia \\
\hline
\end{tabular}

Percebemos ainda que o mesmo grupo de alunos anteriormente mencionados, acabou se empolgando com a discussão, a ponto de questionar o professor a respeito do tamanho do pino presente na radiografia da perna da pessoa, como apresenta a transcrição a seguir:

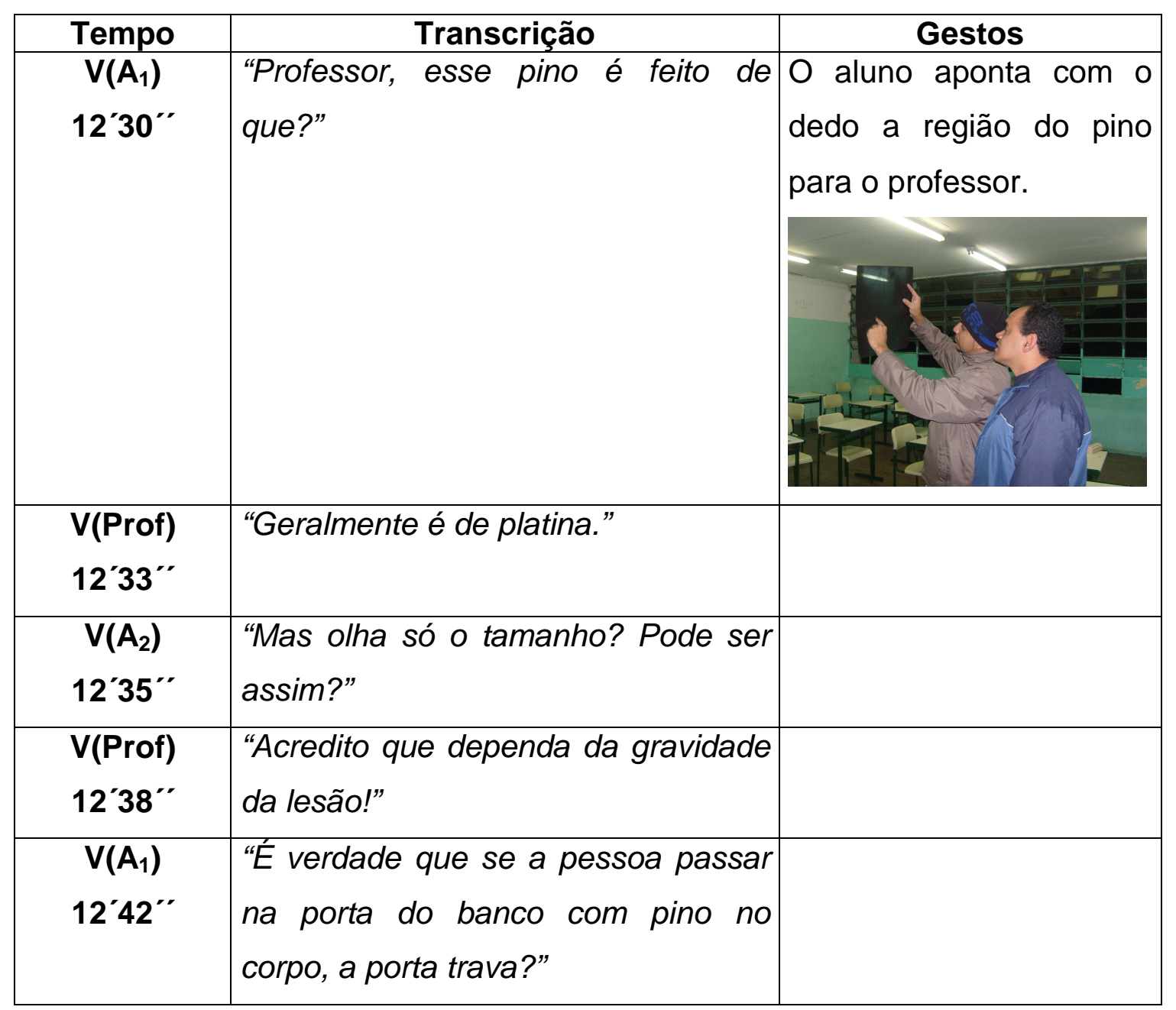




\begin{tabular}{|l|l|}
\hline $\mathbf{V}$ (Prof) & "Dependendo da quantidade de \\
$\mathbf{1 2} \mathbf{4 6}^{\prime \prime}$ & metal, pois a platina é metal, pode \\
ser que o sensor de metais trave a & \\
& porta!"
\end{tabular} \mid

Percebemos que alguns alunos foram além do identificar objetos presentes nas radiografias e conseguiram relacionar a atividade com outros fatos de seu cotidiano. Eles ainda analisaram uma radiografia com uma mancha escura na parte do abdômen e isso gerou uma polêmica, pois segundo eles isso poderia ser indício de gases no estômago, conforme mostra a transcrição a seguir:

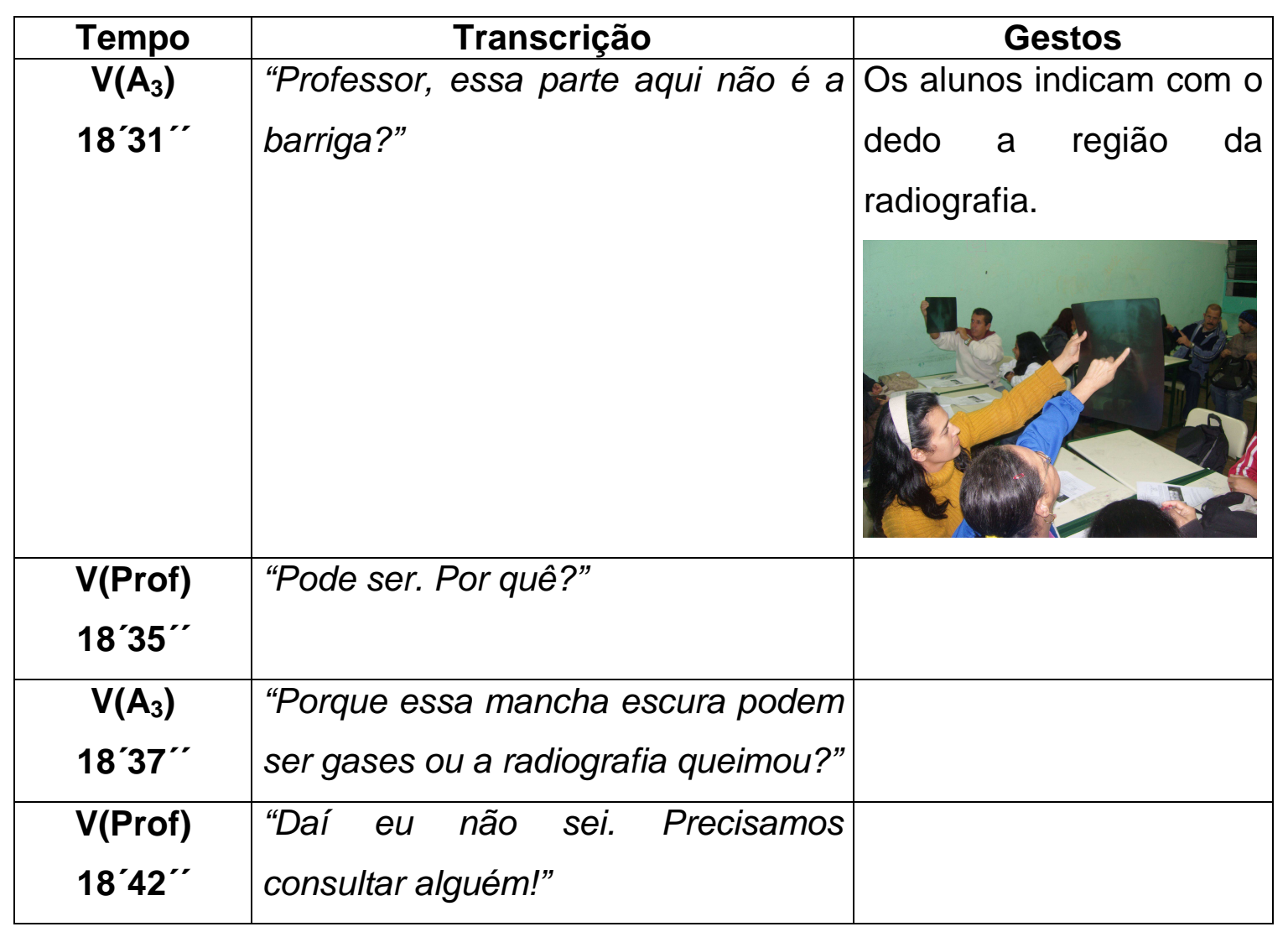

Finalmente, para encaminhar todo o desenvolvimento dessa atividade foi entregue no início um roteiro que serviu como guia da atividade. Esse roteiro continha questões, que foram reforçadas pelo professor antes deles receberem as radiografias, fazendo com que os alunos fossem guiados pelas perguntas para análise e discussões. Ao final do manuseio das radiografias, o professor buscou levantar novamente as questões para iniciar a discussão sobre os raios- $\mathrm{X}$, como no trecho seguinte: 


\begin{tabular}{|c|c|c|}
\hline Tempo & Transcrição & Gestos \\
\hline $\begin{array}{l}\text { V(Prof.) } \\
26^{\prime} 20^{\prime \prime}\end{array}$ & $\begin{array}{l}\text { "O que vocês observaram nas } \\
\text { radiografias?" }\end{array}$ & 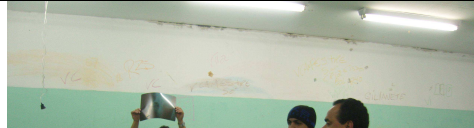 \\
\hline $\begin{array}{l}\mathrm{V}\left(\mathrm{A}_{4}\right) \\
26^{\prime} 23^{\prime \prime}\end{array}$ & "Muitas coisas!" & \\
\hline $\begin{array}{l}\text { V(Prof.) } \\
26^{\prime} 25^{\prime \prime}\end{array}$ & "Por exemplo?" & \\
\hline $\begin{array}{l}\mathrm{V}\left(\mathrm{A}_{4}\right) \\
26^{\prime} 30^{\prime \prime}\end{array}$ & $\begin{array}{l}\text { "Diferentes tons, diferentes partes do } \\
\text { corpo, ..." }\end{array}$ & \\
\hline $\begin{array}{l}\text { V(Prof.) } \\
26^{\prime} 34^{\prime \prime}\end{array}$ & $\begin{array}{l}\text { "Vocês perceberam que tem regiões } \\
\text { que são mais claras e que tem } \\
\text { regiões que são mais escuras?" }\end{array}$ & \\
\hline $\begin{array}{l}\text { V(alunos) } \\
26^{\prime} 40^{\prime \prime}\end{array}$ & “Sim." & \\
\hline $\begin{array}{c}\mathrm{V}\left(\mathrm{A}_{5}\right) \\
26^{\prime} 42^{\prime \prime}\end{array}$ & "Mas por que, professor, é assim?" & \\
\hline $\begin{array}{l}\text { V(Prof) } \\
26^{\prime} 45^{\prime \prime}\end{array}$ & "É isso que vamos descobrir!" & \\
\hline
\end{tabular}

Concluímos que a atividade motivou a participação dos alunos, fazendoos apresentarem perguntas e questionamentos interessantes e pertinentes às imagens que eles estavam analisando nas radiografias, sem, contudo, deixar de lado as questões do roteiro, reforçando o fato de que a atividade foi executada sem problemas pelos alunos. Isso somente corrobora a evidência da operacionalidade, indicando que essa aula com a atividade proposta, é aplicável em sala de aula, tendo sido validada pelos alunos que se interessaram e participaram dela, mostrando ser possível criar uma atividade simples e com questões sobre temas que motivem os alunos.

O caráter da terapêutica também está presente nessa atividade, mostrando o relativo sucesso da mesma. Isso fica evidenciado pelo sucesso que o professor obteve em organizar e conduzir o desenvolvimento da 
atividade, mostrando que não teve problemas em manter a atenção dos alunos para o objetivo da aula, mesmo quando estava explicando o conteúdo, permanecendo por aproximadamente 21 minutos, formalizando a discussão feita com a atividade, sem a turma se dispersar. Ainda podemos encontrar outra manifestação da terapêutica, quando observamos o planejamento da aula e da atividade, uma vez que a aula havia sido planejada em três momentos, tendo esses momentos acontecidos conforme o previsto e bem conduzidos pelo professor, ficando o tempo distribuído da seguinte forma para cada um desses momentos:

- 10 momento: apresentação das questões de orientação da atividade: teve uma duração de 10 minutos;

- 2o momento: aplicação da atividade: teve uma duração de 30 minutos;

- 3o momento: discussão e formalização dos conceitos: teve uma duração de 45 minutos.

Convém ressaltar que para a execução desses momentos, estavam previstos 90 minutos, distribuídos em duas aulas. Percebemos que todo 0 tempo foi ocupado de maneira organizada e conforme previsto no cronograma do curso, o que demonstra mais uma vez a exeqüibilidade da proposta e a necessidade de um bom posicionamento do professor como um condutor e organizador desses momentos. Assim, também podemos inferir a presença do caráter da operacionalidade presente na aula e na atividade, pois as mesmas se mostraram interessantes e motivadoras para os alunos que se envolveram com elas, proporcionando diálogos como os transcritos a seguir:

\begin{tabular}{|c|l|l|}
\hline Tempo & \multicolumn{1}{|c|}{ Transcrição } & \multicolumn{1}{c|}{ Gestos } \\
\hline $\mathbf{V}$ (Prof.) & "Pessoal, quem é que está causando & O professor indica com o \\
32'30" & o aparecimento dessas imagens?" & $\begin{array}{l}\text { dedo a imagem presente } \\
\text { na radiografia. }\end{array}$ \\
\hline
\end{tabular}




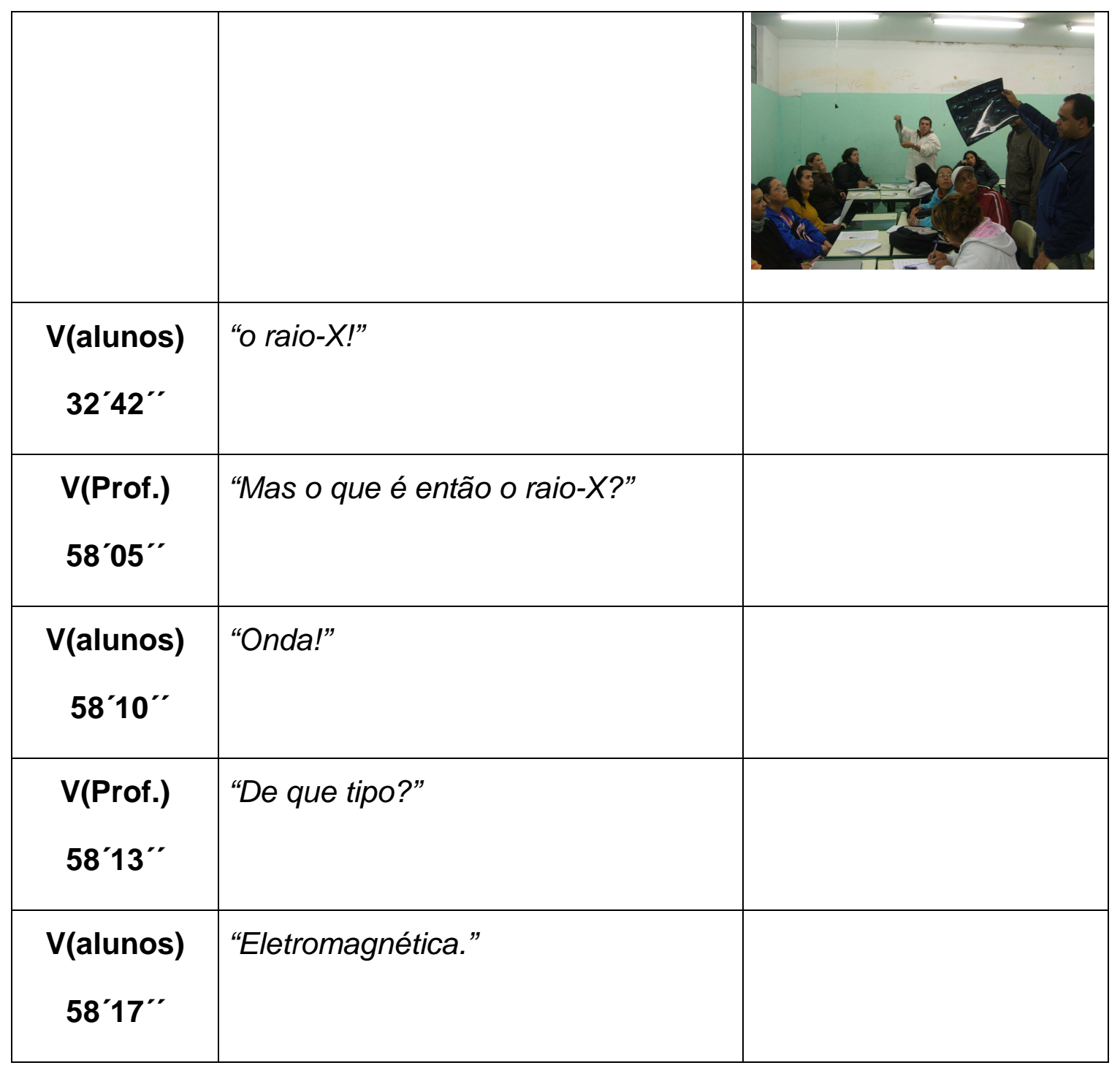

A criatividade didática permitiu fazer uma discussão sobre a produção, detecção e absorção dos raios- $X$ sobre o corpo humano e outros objetos, bem como caracterizar os raios-X como uma onda eletromagnética. Assim, conseguimos elaborar questões na própria atividade e conectá-las com ao texto que foi entregue em seguida (Vendo através da pele: a descoberta dos raios-X) com o objetivo de dar uma maior formalização à discussão e, a partir daí, gerar novas questões para serem respondidas por eles. Dessa forma, vemos o grande potencial que esse tópico possui em criar questões de nível qualitativo para a discussão e o entendimento dos raios- $\mathrm{X}$, justificando assim sua presença na sala de aula, apresentando uma operacionalidade no sentido de transformar esse saber em exercícios e problemas.

Outro detalhe importante é que a própria atividade permitiu fazer conexões com o contexto histórico, uma vez que os alunos foram questionados 
a imaginar como seria, então, o mundo sem os raios- $X$, o que permitiu ao professor nesse momento a inserção de um texto de abordagem histórica, que seria entregue em seguida, para a formalização de toda a discussão sobre os raios-X. Assim, houve um encadeamento da atividade com os textos produzidos no curso. Isso finalmente nos leva a concluir que a atividade auxiliou os alunos a compreenderem melhor o processo de produção e detecção dos raios-X através das chapas radiográficas, mostrando que esse marcador apresenta uma regra essencial no processo da Transposição Didática que é tornar um conceito mais compreensível.

Analisando o aspecto do currículo de física e a rotina escolar, a discussão sobre os raios- $X$ se faz necessária, uma vez que esse ente físico está no cotidiano das pessoas, mas elas não o conhecem bem. Desse modo, a escola torna-se um meio de acesso, no qual, os jovens podem ter um conhecimento maior sobre os aspectos dos raios- $X$, eliminando mitos e crendices, erguendo um conhecimento mais sólido e com explicações menos distorcidas pelo saber popular. Assim, justifica-se sua presença em sala de aula por trazer uma atualização moral, por se tratar de um tópico importante a ser discutido em sala de aula e presente no currículo de física do Ensino Médio, levando a uma atualização do saber escolar.

\subsection{3 - Terceiro Marcador-Estruturante}

Definimos como atividade materializadora do terceiro marcadorestruturante do curso a atividade que desenvolve o conceito de Estabilidade Nuclear. Esta atividade foi determinada como um novo marcador porque além de fazer uso de um modelo para explicar a estabilidade entre prótons e nêutrons no interior do núcleo atômico, também permite caracterizar os elementos radioativos (instáveis) presentes na tabela periódica e na natureza. É, assim, uma atividade introdutória ao estudo da radioatividade e das emissões radioativas emitidas por certos elementos, caracterizando uma outra classificação para as radiações, as chamadas radiações corpusculares. 


\subsubsection{1 - Descrição da atividade}

Inicialmente foram entregues aos alunos tabelas periódicas para que eles pudessem identificar quais os elementos que nelas aparecem classificados como radioativos. Essa tabela foi extraída do encarte de um livro didático ${ }^{9}$ de química e sua escolha ocorreu pelo fato de junto aos símbolos dos elementos encontrarmos, além das características como massa atômica, número atômico e estado físico, também a presença da identificação do elemento como radioativo ou não. Esse fator é importante para a atividade, uma vez que permite identificar na tabela periódica a partir de qual elemento temos o início das séries radioativas e até onde os elementos na tabela são estáveis.

A atividade foi realizada em grupos de 2 ou 3 alunos, na qual era pedido para que procurassem identificar o número de massa dos elementos fornecidos pelo professor, bem como seu número atômico, determinando em seguida o número de nêutrons e, finalmente, a identificação deles como sendo elementos radioativo ou não (estáveis). Em seguida, foi solicitado pelo professor para que eles buscassem entre esses elementos características entre as quais lhes permitissem justificar a razão pela qual esses elementos eram classificados como radioativos (Figura 6).
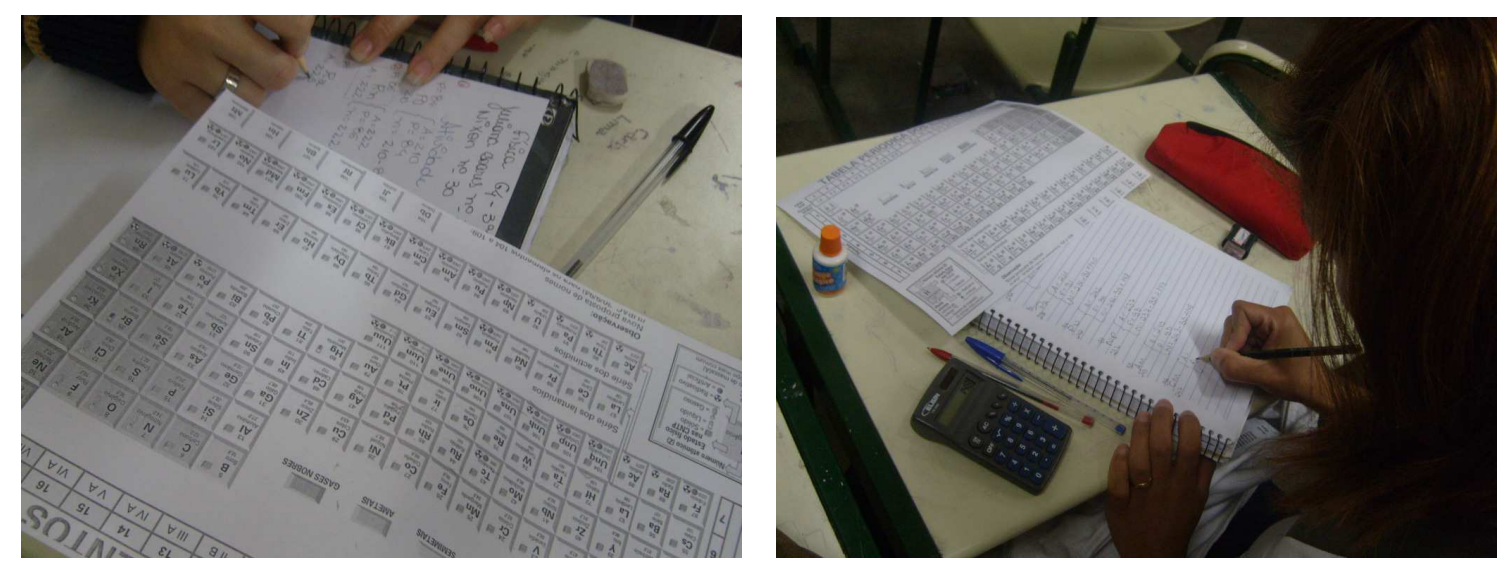

${ }^{9}$ USBERCO \& SALVADOR. Química Geral. Volume único. 6ª ed. São Paulo: Ed. Saraiva, 2008. 

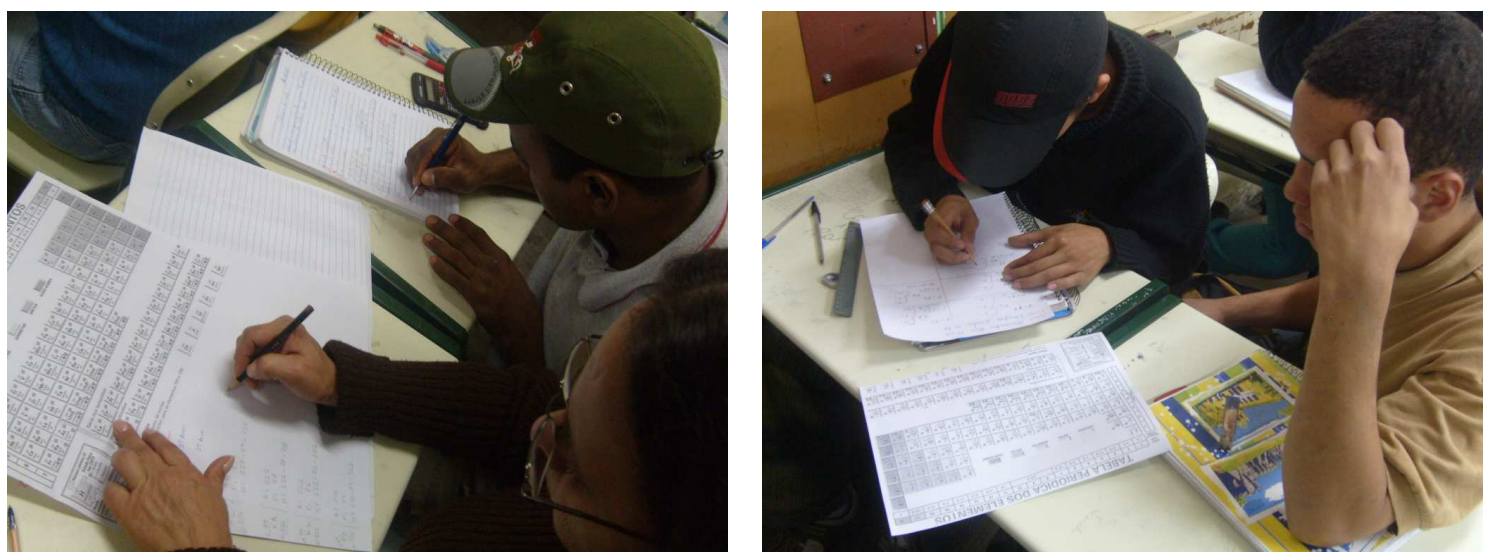

Figura 6 - Alunos realizando a atividade sobre a estabilidade nuclear.

A atividade então se desenvolveu em torno dessa busca de encontrar indícios que justificassem a estabilidade nuclear de alguns elementos e a falta de estabilidade nuclear de outros, ou dita de uma forma diferente, por que razão alguns elementos emitem radiação e outros não? Essa questão norteou a análise dos elementos e suas características, procurando nelas uma explicação razoável para esse fenômeno.

\subsubsection{2 - A análise do terceiro marcador-estruturante}

O principal objetivo dessa atividade foi o de apresentar como se dá a estabilidade nuclear e em que limite ela deixa de ocorrer, ou seja, em que condições o núcleo atômico se torna instável, possibilitando que o átomo passe a emitir radiações e sofra decaimentos, de forma que seu núcleo novamente se torne estável. Essa atividade também teve como objetivo trazer à discussão uma nova forma de radiação, a radiação corpuscular, pois até então as atividades anteriores do curso procuraram explorar no espectro eletromagnético apenas as radiações eletromagnéticas. Com isso, é possível fazer a inserção da radioatividade e das radiações alfa, beta e gama, embora a radiação gama tenha uma natureza eletromagnética. Assim, também não foi deixado de lado o contexto histórico, que mostra como a radioatividade surge e que contribuições essa nova teoria trouxe para o entendimento da natureza e do próprio modelo atômico, além de contribuir para o desenvolvimento de novas áreas na física. 
Analisando a atividade podemos constatar que o seu desenvolvimento ocorreu de uma maneira bastante tranqüila e aberta, deixando os alunos à vontade para que investigassem e discutissem os elementos presentes na tabela periódica, gerando um interesse e entusiasmo entre eles em trabalhar com um objeto que aparentemente só aparecia nas aulas de química. Dessa forma, conseguimos envolver os alunos presentes (34 alunos) em uma atividade simples e que embora não fosse de caráter experimental, também não deixou de apresentar seu caráter investigativo e muito menos de aplicação de uma metodologia científica.

Esses aspectos marcantes nessa aula e presentes nos marcadoresestruturantes anteriores continuam nos fornecendo um forte indício da presença da operacionalidade do nosso marcador. Assim, a questão proposta pelo professor teve o intuito de gerar uma tarefa para os alunos, para que ele posteriormente fizesse uma conceituação formal do saber que estava sendo discutido na atividade.

A manipulação das tabelas periódicas e a sua compreensão, e posterior análise dos dados obtidos dela como massa atômica, número atômico, número de prótons, número de nêutrons e classificação dos elementos como radioativos ou não, também foi o ponto alto da atividade. Ela durou cerca de 20 minutos, dentro do tempo previsto no planejamento da aula, sem que ocorressem maiores problemas, exceto quanto ao fato de que na tabela utilizada ter a massa atômica e o número atômico, posicionados em uma ordem que não é a usual. A IUPAC (União Internacional de Química Pura e Aplicada) determina que todo elemento $(X)$ seja representado pelo seu símbolo acompanhado da sua massa atômica (A) e seu número atômico (Z), sendo representado da seguinte forma ${ }_{Z}^{A} X$, enquanto que em nossa tabela essas informações encontravam-se invertidas $\left({ }_{A}^{Z} X\right)$. Entretanto, na própria tabela encontrava-se uma advertência e uma legenda referindo-se a esse detalhe.

Durante a análise das tabelas, os alunos conseguiram identificar facilmente os elementos radioativos, porém não chegavam a um consenso quanto ao critério para ser radioativo ou não, como mostra o diálogo a seguir: 


\begin{tabular}{|c|c|c|}
\hline Tempo & Transcrição & Gestos \\
\hline $\begin{array}{l}V\left(A_{1}\right): \\
10^{\prime} 37^{\prime \prime}\end{array}$ & "Esse elemento é radioativo!" & $\begin{array}{l}\text { Aponta para o elemento } \\
\text { na tabela periódica com } \\
\text { a caneta. }\end{array}$ \\
\hline $\begin{array}{l}V\left(A_{2}\right): \\
10^{\prime} 41^{\prime \prime}\end{array}$ & "Como você sabe?" & \\
\hline $\begin{array}{l}V\left(A_{1}\right): \\
10^{\prime} 44^{\prime \prime}\end{array}$ & $\begin{array}{l}\text { "Olha esse símbolo aqui! Ele indica } \\
\text { que o elemento é radioativo." }\end{array}$ & $\begin{array}{l}\text { Aponta para o símbolo } \\
\text { da radioatividade ao lado } \\
\text { do símbolo do elemento. }\end{array}$ \\
\hline $\begin{array}{l}V\left(A_{2}\right): \\
10^{\prime} 47^{\prime \prime}\end{array}$ & "Mas por que ele é radioativo?" & \\
\hline $\begin{array}{l}V\left(A_{1}\right): \\
10^{\prime} 50^{\prime \prime}\end{array}$ & $\begin{array}{l}\text { "Aí eu não sei ainda. Mas a partir } \\
\text { desse elemento é que começam os } \\
\text { radioativos!" }\end{array}$ & $\begin{array}{l}\text { Aponta para o símbolo } \\
\text { do elemento na tabela. }\end{array}$ \\
\hline
\end{tabular}

Outro grupo de alunos também discute o critério para que o elemento seja radioativo ou não, como apresenta a transcrição a seguir:

\begin{tabular}{|c|c|c|}
\hline Tempo & Transcrição & Gestos \\
\hline $\begin{array}{l}V\left(A_{5}\right) \\
17^{\prime} 20^{\prime \prime}\end{array}$ & $\begin{array}{l}\text { "O professor falou que esse símbolo } \\
\text { indica que o elemento é radioativo!" }\end{array}$ & \\
\hline $\begin{array}{l}V\left(A_{6}\right) \\
17^{\prime} 23^{\prime \prime}\end{array}$ & "Tá, mais qual o critério?” & \\
\hline $\begin{array}{l}\mathrm{V}\left(\mathrm{A}_{5}\right) \\
17^{\prime} 25^{\prime \prime}\end{array}$ & $\begin{array}{l}\text { "Eu acho que tem a ver com a } \\
\text { massa!" }\end{array}$ & \\
\hline $\begin{array}{l}V\left(A_{6}\right) \\
17^{\prime} 28^{\prime \prime}\end{array}$ & "Por quê?" & \\
\hline $\begin{array}{l}V\left(A_{5}\right) \\
17^{\prime} 31^{\prime \prime}\end{array}$ & $\begin{array}{l}\text { "Porque a massa deles é muito } \\
\text { grande!" }\end{array}$ & \\
\hline
\end{tabular}




\begin{tabular}{|c|l|l|}
\hline $\mathbf{V}\left(\mathbf{A}_{\mathbf{6}}\right)$ & "Eu acho que não, porque esse aqui & O aluno aponta para o \\
$\mathbf{1 7} \mathbf{3 4}^{\prime} "$ & tem massa grande e não é!" & elemento na tabela. \\
& &
\end{tabular}

Percebemos que alguns alunos foram aos poucos cercando e definindo 0 critério para que eles pudessem caracterizar o elemento como radioativo ou não. Finalmente, para encaminhar todo o desenvolvimento dessa atividade foi entregue no início um roteiro que serviu como guia da atividade. Esse roteiro continha questões, que foram reforçadas pelo professor antes deles receberem as tabelas periódicas, fazendo com que os alunos fossem guiados pelas perguntas para análise e discussões. Ao término da identificação das possíveis causas dos elementos serem radioativos (instáveis), o professor buscou levantar novamente as questões para iniciar a discussão sobre a estabilidade, como no trecho seguinte:

\begin{tabular}{|c|c|c|}
\hline Tempo & Transcrição & Gestos \\
\hline $\begin{array}{l}\text { V(Prof.) } \\
28^{\prime} 10^{\prime \prime}\end{array}$ & $\begin{array}{l}\text { "O que vocês observaram na tabela } \\
\text { periódica? Digo, tem muitos ou } \\
\text { poucos elementos radioativos?" }\end{array}$ & \\
\hline $\begin{array}{l}V\left(A_{4}\right) \\
28^{\prime} 13^{\prime \prime}\end{array}$ & $\begin{array}{l}\text { "Comparados aos outros não são } \\
\text { muitos." }\end{array}$ & \\
\hline $\begin{array}{l}\text { V(Prof.) } \\
28^{\prime} 15^{\prime \prime}\end{array}$ & $\begin{array}{l}\text { "Por que alguns são e outros não, } \\
\text { então?" }\end{array}$ & \\
\hline $\begin{array}{l}V\left(A_{4}\right) \\
28^{\prime} 20^{\prime \prime}\end{array}$ & “Tem a ver com a massa?” & \\
\hline $\begin{array}{l}\text { V(Prof.) } \\
28^{\prime} 24^{\prime \prime}:\end{array}$ & $\begin{array}{l}\text { "Vocês perceberam que a partir de } \\
\text { certo número atômico os elementos } \\
\text { começam a ser radioativos?" }\end{array}$ & \\
\hline $\begin{array}{l}\text { V(alunos) } \\
28^{\prime} 27^{\prime \prime}\end{array}$ & "É verdade." & \\
\hline
\end{tabular}




\begin{tabular}{|c|c|c|}
\hline $\begin{array}{l}\mathrm{V}\left(\mathbf{A}_{5}\right) \\
28^{\prime} 28^{\prime \prime}\end{array}$ & “Mas, por que, professor é assim?" & \\
\hline $\begin{array}{l}\mathrm{V}\left(\mathrm{A}_{1}\right) \\
28^{\prime} 30^{\prime \prime}\end{array}$ & $\begin{array}{l}\text { "Então é por causa do número } \\
\text { atômico!" }\end{array}$ & \\
\hline $\begin{array}{l}\mathrm{V}\left(\mathbf{A}_{5}\right) \\
28^{\prime} 28^{\prime \prime}\end{array}$ & "Só isso?" & \\
\hline $\begin{array}{l}\mathrm{V}\left(\mathrm{A}_{1}\right) \\
28^{\prime} 30^{\prime \prime}\end{array}$ & $\begin{array}{l}\text { "Eu acho que sim. Tá vendo que a } \\
\text { partir desse } 83 \text { começam os } \\
\text { radioativos!" }\end{array}$ & $\begin{array}{l}\text { Aponta para a tabela e o } \\
\text { elemento da tabela. }\end{array}$ \\
\hline
\end{tabular}

Concluímos através disso que a atividade motivou a participação dos alunos, fazendo-os apresentarem perguntas e questionamentos interessantes sem, contudo, deixar de lado as questões do roteiro, reforçando o fato de que a atividade foi executada sem problemas pelos alunos. Dessa forma, temos novamente uma evidência da operacionalidade, indicando que essa aula com a atividade proposta, é aplicável em sala de aula, tendo sido validada pelos alunos que se interessaram e participaram dela, mostrando ser possível criar uma atividade simples e com questões sobre o tema que motivem os alunos.

A terapêutica também está presente nessa atividade, mostrando o relativo sucesso da mesma, o que fica evidenciado pelo sucesso que o professor obteve em mais uma vez coordenar o desenvolvimento da atividade. Foram aproximadamente 25 minutos formalizando a discussão feita com a atividade, sem que a turma sofresse dispersão e a aula se tornasse monótona, sem levar em consideração que os momentos da aula ocorreram conforme o esperado e bem conduzidos pelo professor, ficando o tempo distribuído da seguinte forma para cada um desses momentos:

- 19 momento: apresentação das questões de orientação da atividade: teve uma duração de 10 minutos;

- 20 momento: aplicação da atividade: teve uma duração de 25 minutos;

- 3o momento: discussão e formalização dos conceitos: teve uma duração de 45 minutos. 
Estavam previstos 90 minutos para a execução e discussão da atividade, distribuídos em duas aulas. Percebemos que todo o tempo foi ocupado de maneira coerente e conforme previsto no cronograma do curso, o que demonstra mais uma vez a exeqüibilidade. Assim, também podemos inferir a presença do caráter da operacionalidade presentes na aula e na atividade, pois as mesmas se mostraram interessantes e motivadoras para os alunos que se envolveram com elas, proporcionando partes dos diálogos já apresentados anteriormente.

Podemos considerar que o aspecto da atualização também esteve presente nessa atividade, pois um dos seus objetivos era mostrar que o núcleo atômico é mais complexo que até então era conhecido, além de possuir forças de natureza que ainda continuam a ser pesquisadas, como a força nuclear forte. Também foi possível abordar a problemática existente no decaimento beta, uma vez que surge a necessidade de justificar a saída de um elétron do interior do núcleo atômico, o que causa certa contradição com o modelo nuclear que é conhecido. Assim, a descrição da matéria estava, dessa forma, mais próxima daquela aceita e trabalhada pela comunidade científica, justificando a atualização biológica desse saber, uma vez que prevê que o saber deva estar próximo daquele vigente na comunidade científica para ser reconhecida sua atualização biológica. Essa atividade contribuiu para uma atualização do saber escolar, por mostrar uma descrição mais atual da estrutura do núcleo e das forças que lá interagem entre suas partículas.

Houve também uma criatividade didática ao se trabalhar com essa atividade, mostrando uma outra possibilidade de uso da tabela periódica que não fosse apenas para verificar a família dos elementos como é muito usual em química, sendo assim, mais um recurso didático para levar a uma melhor compreensão das idéias relacionadas com a estrutura nuclear e dos decaimentos radioativos, tornando o conceito mais compreensível para os alunos. 


\subsection{4 - Quarto Marcador-Estruturante}

Para finalizar a proposta, levando em conta os objetivos traçados inicialmente, o quarto marcador-estruturante e último do curso de Física das Radiações fica materializado através da atividade Detectores de Radiação. Esta atividade tem como objetivo permitir que os alunos tenham o contato com mecanismos e dispositivos usados para detecção dos diversos tipos de radiações, sejam elas eletromagnéticas ou corpusculares.

Assim, ela apresenta como conteúdo para os alunos do Ensino Médio o contador Geiger e os cintilômetros, além de apresentar o uso de câmaras de nuvens e bolhas para verificação dos rastros de partículas, como por exemplo, a partícula alfa que ao atravessarem um caminho no interior desses dispositivos apresentam um rastro característico. Nessa atividade procura-se apresentar o uso das emulsões fotográficas usadas para visualizar o rastro das radiações cósmicas, pois assim, é possível apresentar aos alunos um dos personagens mais ilustres da física brasileira - César Lattes, e finalmente, retomar o uso das radiografias que permitem identificar os efeitos dos raios- $X$ sobre a matéria, fornecendo imagens de seu interior.

Outro detalhe interessante dessa atividade é que ela permite estimular os estudantes a perceberem a importância dos nossos sentidos e órgãos que dispomos naturalmente para detecção das diferentes formas de radiação, onde podemos citar, como exemplos, a nossa visão que é sensível a luz visível, mas que não detecta, ou seja, é "cega" para a presença dos raios infravermelhos, sendo necessário um órgão do corpo humano para realizar tal detecção, nesse caso, a nossa pele, que é rica em terminais nervosos responsáveis por um dos cinco sentidos que temos, o nosso tato.

\subsubsection{1 - Descrição da atividade}

A atividade procurou fazer uso de um papel fotográfico (Figura 7), papel esse semelhante ao que usamos para tirar fotografias em câmeras fotográficas analógicas. Esse papel é recoberto com uma substância sensível a luz (sais de prata) e permite fazer uma analogia com o processo de detecção dos raios-X 
através da radiografia, ou mesmo, das emulsões fotográficas utilizadas por César Lattes na detecção dos raios cósmicos.

Assim, a atividade foi realizada em grupos de 2 ou 3 alunos, onde inicialmente foi entregue a eles um papel fotográfico virgem sendo solicitado que sobre o papel sejam colocados objetos diversos, objetos estes que estejam disponíveis na sala, como régua, lápis, borracha, chaves, celular e outros. Em seguida, pediu-se que eles aguardassem um pequeno período de tempo (5 minutos), e em seguida, que eles retirassem os objetos que estão sobre o papel e verificassem o que ocorreu.
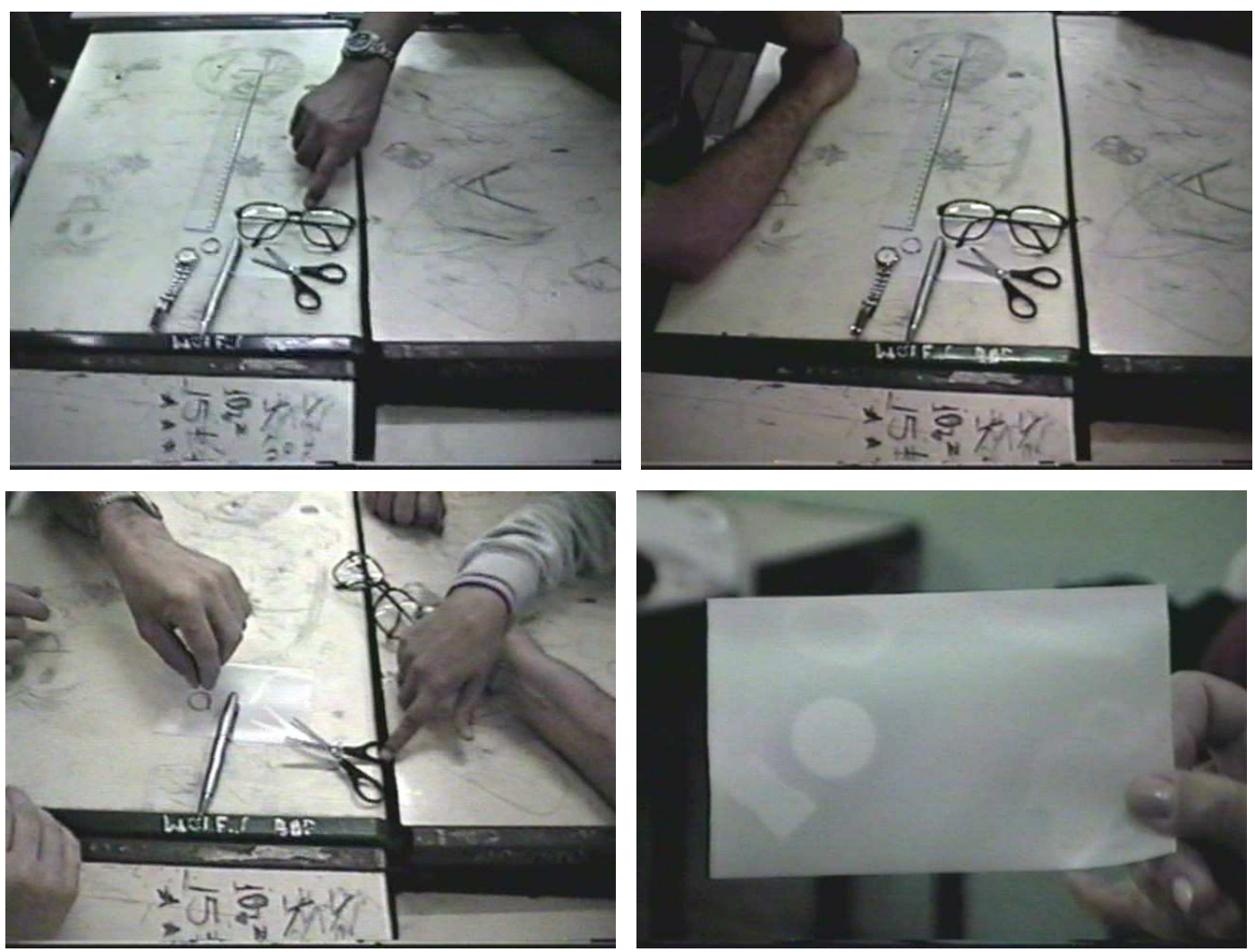

Figura 7 - Alunos realizam a atividade do papel fotográfico.

A atividade, então, se desenvolveu em torno de os alunos justificarem a razão pela qual a imagem dos objetos ficou registrada no papel fotográfico que foi entregue a eles, pedindo que eles fizessem uma analogia com as radiografias que já haviam sido usadas em outra atividade (segundo marcadorestruturante), onde os raios- $X$ causaram 0 aparecimento das imagens, enquanto aqui a luz emitida pelas lâmpadas que iluminam a sala é que seriam as responsáveis pelo aparecimento das imagens ao sensibilizar o papel 
fotográfico. Essa analogia leva, então, à possibilidade de inserção de uma técnica semelhante a que foi usada pelo grupo de pesquisa ao qual César Lattes fazia parte, na tentativa de detecção dos raios cósmicos e que possibilitou, mais tarde, a descoberta do méson pi.

\subsubsection{2 - A análise do quarto marcador-estruturante}

O principal objetivo dessa atividade é o de apresentar os detectores de radiação, fazendo uso de uma analogia entre as imagens que são geradas em um papel fotográfico exposto à luz visível e o processo dos raios- $X$ que causam o aparecimento de imagens em radiografias, mostrando que o papel fotográfico é capaz de detectar a ação da luz visível ao entrar em contato com ele, assim como o nosso olho é sensibilizado por essa radiação e não a outras. Da mesma forma, a radiografia é um detector para os raios- $X$, enquanto as emulsões que César Lattes teve que desenvolver possibilitaram a detecção dos raios cósmicos.

O desenvolvimento da atividade foi realizada de uma maneira aberta e dinâmica, deixando os alunos à vontade para que investigassem e discutissem como a imagem dos objetos pode ficar registrada no papel fotográfico. Dessa forma, conseguimos notar que a aula transcorreu de uma forma tranqüila, não havendo problemas com disciplina ou rejeição dos alunos quanto a execução da atividade. Podemos afirmar que esses foram aspectos marcantes na aula, afinal notamos que os alunos estavam focados na atividade e não em outras coisas. Constatamos que todos os alunos presentes (35 alunos), participaram da atividade emitindo opiniões e questionando aspectos interessantes de sua execução e/ou resultados, procurando identificar as questões que o professor havia proposto no início da atividade.

Podemos afirmar que temos uma aplicação da operacionalidade do nosso marcador, uma vez que a operacionalidade está ligada diretamente à capacidade que o novo saber tem em gerar algum tipo de questão ou tarefa que possa ser avaliada pelo professor e que busque a conceituação do saber, o que ocorreu, conforme mostra a transcrição a seguir: 


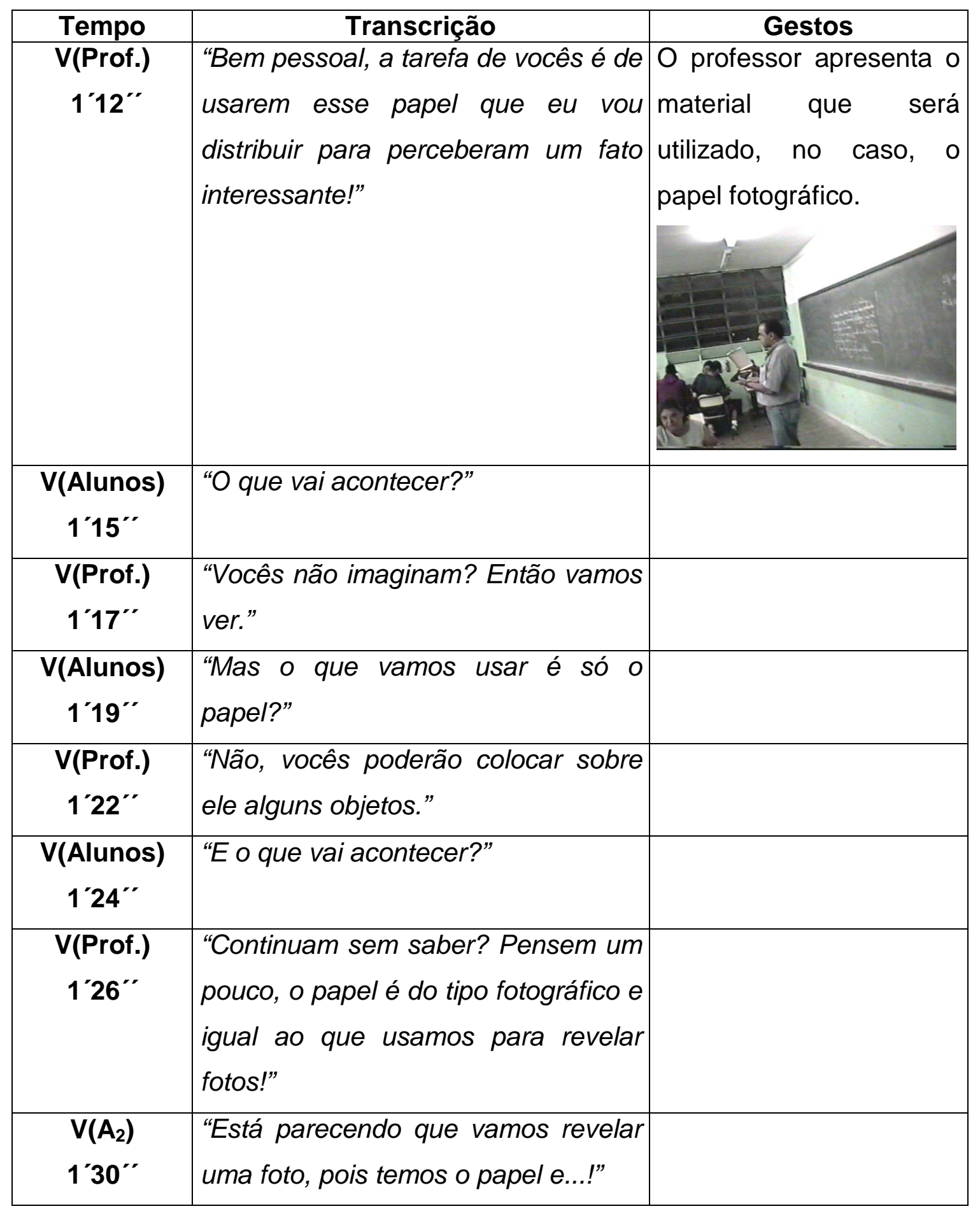

A atividade teve uma duração curta, cerca de 10 minutos, conforme 0 tempo previsto no planejamento da aula. Além disso, os alunos não mostraram qualquer dificuldade para executá-la, fazendo uso de materiais que estavam disponíveis na própria sala de aula. O único detalhe encontra-se no uso do próprio papel fotográfico que foi adquirido pelo professor antes da aula em lojas especializadas em revelação de fotos. O papel veio acondicionado em uma 
caixa e envolto em um plástico escuro para evitar a sua queima pela ação da luz direta, conforme explica o professor na transcrição a seguir:

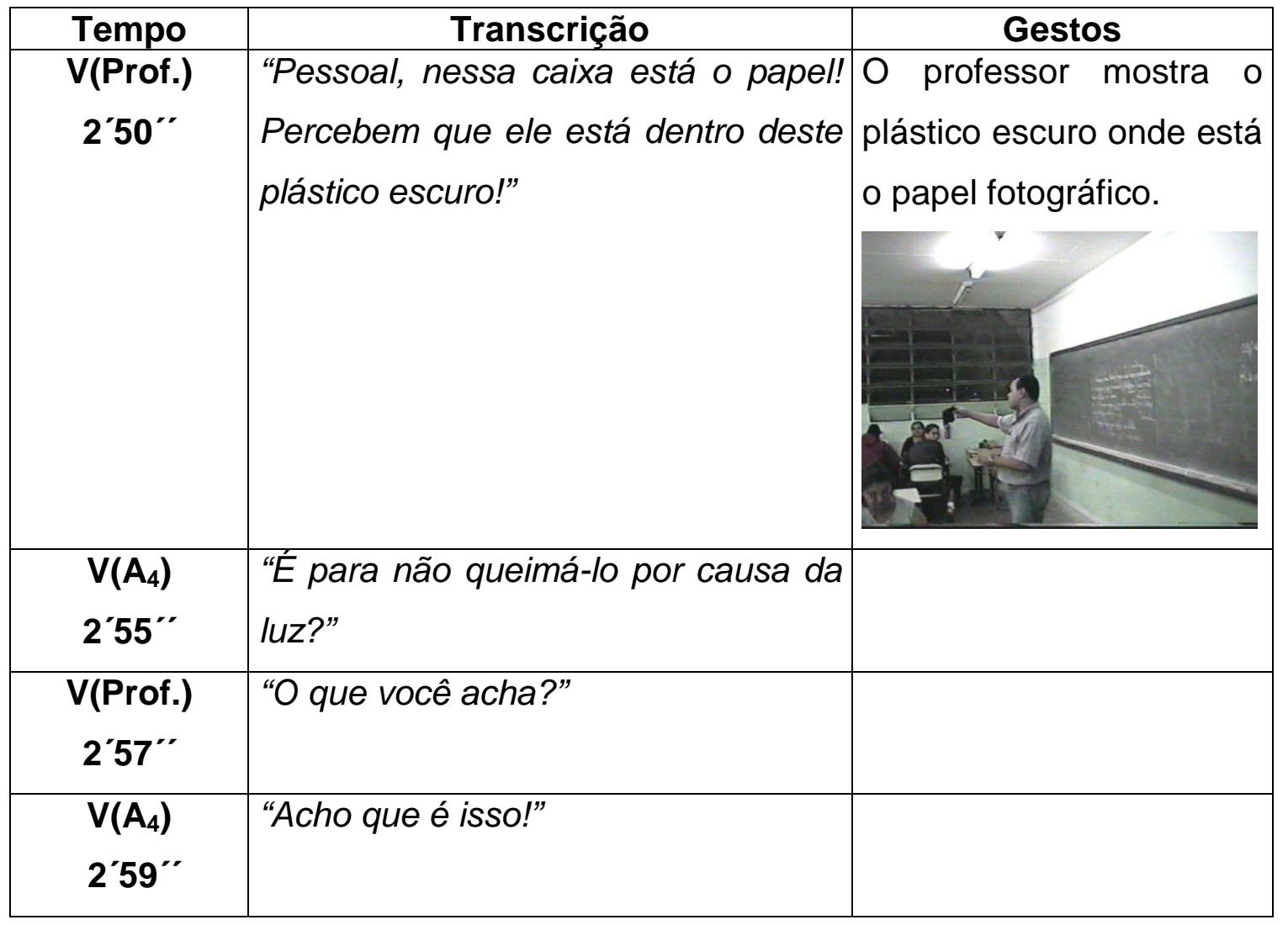

Percebemos, com isso, que alguns alunos já conseguiram relacionar a ação da luz proveniente das lâmpadas sobre o papel fotográfico, como um elemento importante na atividade. Assim, após a execução da atividade, ou seja, depois de os objetos terem sido removidos de cima do papel fotográfico e a sua imagem ficar registrada nele, constatamos que isso causou uma surpresa nos alunos, mostrando que o resultado obtido foi surpreendente, conforme mostra a transcrição a seguir:

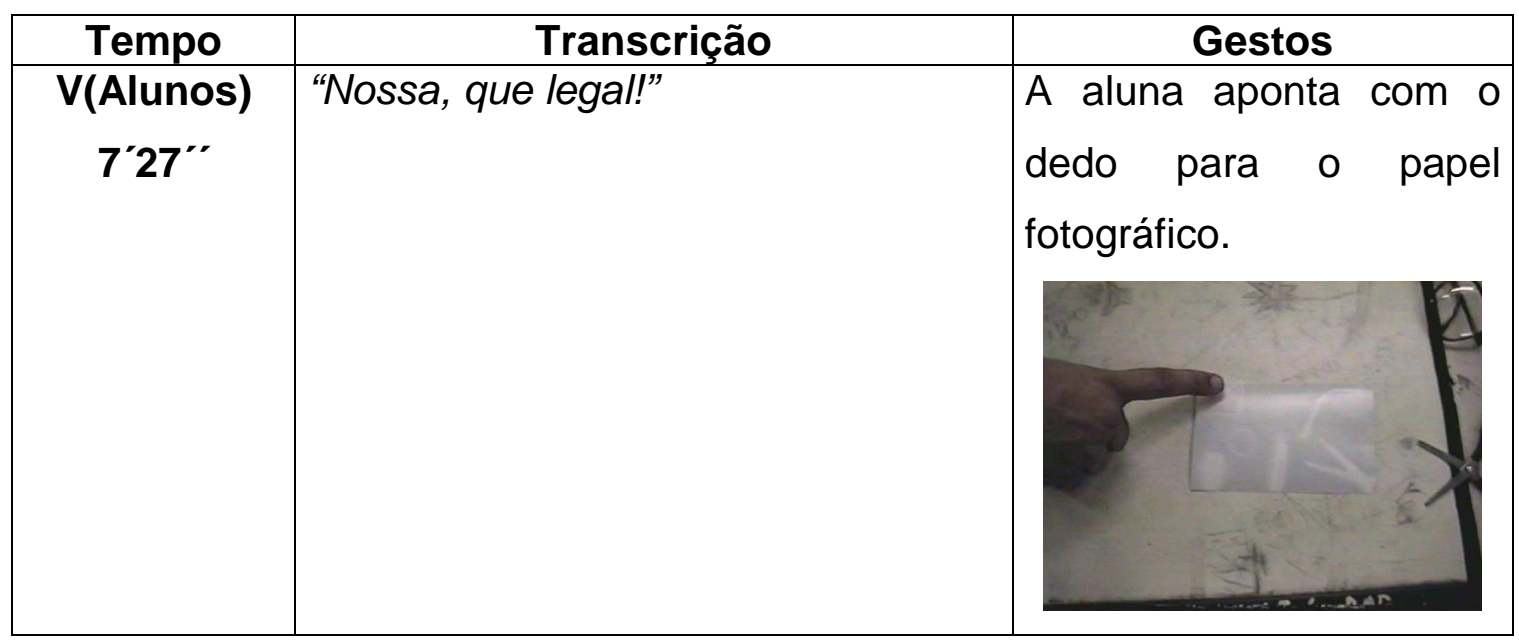




\begin{tabular}{|c|l|l|}
\hline $\mathbf{V ( P r o f )}$ & "E aí? O que vocês acharam?" & \\
$\mathbf{7} \mathbf{2} \mathbf{2 9}$ & & \\
\hline $\mathbf{V}\left(\mathbf{A}_{3}\right)$ & "Bem interessante! Dá pra ver até os & \\
$\mathbf{7} \mathbf{3 1} "$ & detalhes dos objetos!" & \\
\hline
\end{tabular}

Em seguida, após a conclusão da atividade, o professor encaminha para a discussão das questões que estavam no roteiro entregue no início da atividade. Esse roteiro acabou fazendo com que os alunos fossem guiados pelas perguntas para análise e discussões, como no trecho seguinte:

\begin{tabular}{|c|c|c|}
\hline Tempo & Transcrição & Gestos \\
\hline $\begin{array}{c}\text { V(Prof.) } \\
15^{\prime} 30^{\prime \prime}\end{array}$ & $\begin{array}{l}\text { "E aí?Alguém poderia me dizer como } \\
\text { a imagem se forma no papel } \\
\text { fotográfico?" }\end{array}$ & \\
\hline $\begin{array}{c}V\left(A_{4}\right) \\
15^{\prime} 33^{\prime \prime}\end{array}$ & "Por causa da luz!" & \\
\hline $\begin{array}{l}\text { V(Prof.) } \\
15^{\prime} 35^{\prime \prime}\end{array}$ & "Mas como?" & \\
\hline $\begin{array}{l}V\left(A_{2}\right) \\
15^{\prime} 40^{\prime \prime}\end{array}$ & "O papel escurece!” & \\
\hline $\begin{array}{c}\text { V(Prof.) } \\
15^{\prime} 44^{\prime \prime}\end{array}$ & "E isso significa o quê?" & \\
\hline $\begin{array}{c}\text { V(alunos) } \\
15^{\prime} 47^{\prime \prime}\end{array}$ & "Como assim?" & \\
\hline $\begin{array}{l}\text { V(Prof.) } \\
15^{\prime} 48^{\prime \prime}\end{array}$ & "O que aconteceu com o papel?" & \\
\hline $\begin{array}{c}\mathrm{V}\left(\mathrm{A}_{2}\right) \\
15^{\prime} 50^{\prime \prime}\end{array}$ & "A luz queimou o papel?" & \\
\hline $\begin{array}{c}V\left(A_{4}\right) \\
15^{\prime} 52^{\prime \prime}\end{array}$ & "Eu já tinha falado isso no começo!" & \\
\hline
\end{tabular}

A partir dessa transcrição, podemos perceber que a atividade motivou a participação dos alunos, fazendo-os argumentarem e questionarem, sem deixar de lado as questões do roteiro, reforçando o fato de que a atividade foi 
executada sem problemas pelos alunos, o que reafirma a evidência da operacionalidade.

Também está presente o caráter da terapêutica nessa atividade, mostrando o relativo sucesso da mesma, o que fica evidenciado pelo sucesso que o professor obteve em organizar e conduzir o desenvolvimento da atividade, permanecendo por aproximadamente 22 minutos na formalização do conteúdo presente na atividade, sem a turma se dispersar. A terapêutica também está presente quando observamos o planejamento da aula e da atividade, uma vez que a aula havia sido planejada para que acontecessem três momentos, que aconteceram conforme a previsão e organização da aula, ficando distribuídos da seguinte forma:

- 1ำ momento: apresentação das questões de orientação da atividade: teve uma duração de 10 minutos;

- 2o momento: aplicação da atividade: teve uma duração de 10 minutos;

- 3o momento: discussão e formalização dos conceitos: teve uma duração de 35 minutos.

Para a execução desses momentos, estavam previstos 90 minutos, distribuídos em duas aulas. Percebemos que nem todo o tempo foi ocupado, o que possibilitou que os alunos fizessem a leitura do texto "Detectores de Radiação", o que reforça a organização da proposta, demonstrando sua exeqüibilidade. Podemos também constatar que a atividade permitiu fazer conexões com o contexto histórico, uma vez que os alunos foram questionados sobre se conheciam algum físico brasileiro famoso. Infelizmente a resposta obtida não foi a esperada, principalmente pela surpresa que os estudantes demonstraram ao saber que o físico brasileiro César Lattes utilizou algo parecido com um filme fotográfico (emulsão) para detectar os raios cósmicos, o que pode ser visto na transcrição a seguir:

\begin{tabular}{|c|l|c|}
\hline Tempo & \multicolumn{1}{|c|}{ Transcrição } & Gestos \\
\hline V(Prof.) & "E o César Lattes? Quem já tinha & \\
29'30" & ouvido falar dele?” & \\
\hline
\end{tabular}




\begin{tabular}{|c|c|}
\hline $\begin{array}{c}\text { V(alunos) } \\
29^{\prime} 32^{\prime \prime}\end{array}$ & “...(silêncio)...” \\
\hline $\begin{array}{l}\text { V(Prof.) } \\
29^{\prime} 35^{\prime \prime}\end{array}$ & "Ninguém?!?" \\
\hline $\begin{array}{c}\text { V(Prof.) } \\
29^{\prime} 36^{\prime \prime}\end{array}$ & "E outro físico brasileiro famoso?" \\
\hline $\begin{array}{c}\text { V(alunos) } \\
29^{\prime} 38^{\prime \prime}\end{array}$ & “... (silêncio)...” \\
\hline
\end{tabular}

A criatividade didática permitiu fazer uma conexão com a discussão sobre a produção, detecção e absorção dos raios-X sobre o corpo humano e outros objetos. Assim, conseguimos elaborar questões na própria atividade e conectálas com o texto que foi entregue em seguida com o objetivo de dar uma maior formalização à discussão e, a partir daí, gerar novas questões para serem respondidas por eles. Percebemos, então, o grande potencial que esse tópico possui em criar questões de nível qualitativo para a discussão e o entendimento dos detectores de radiação, além de permitir trazer aspectos históricos para a sala de aula, justificando assim sua presença na sala de aula, apresentando uma operacionalidade no sentido de transformar esse saber em exercícios e problemas.

Quanto à atualização moral, ela está presente por se tratar de um tópico importante a ser discutido em sala de aula e presente no currículo de física do Ensino Médio, ainda mais quando pensamos em trazer para a sala de aula um pouco do que os físicos brasileiros, pessoas essas desconhecidas em nosso próprio país, proporcionaram para o desenvolvimento da própria física. Assim, podemos afirmar que temos uma atualização do saber escolar, pois trazemos para a discussão detectores de radiação, enfatizando aqueles que dispomos naturalmente em nosso corpo e daqueles que tiveram que ser desenvolvidos. 


\section{4 - Analisando a estrutura do curso através do questionário}

Com o intuito de analisar o conteúdo do curso, elaboramos um questionário com perguntas objetivas, procurando dar ênfase sobre a seqüência proposta, as atividades realizadas, as questões trabalhadas e outros elementos que acreditamos serem pertinentes para poder fazer uma avaliação geral da estrutura do curso, na visão dos alunos. Para isso, baseamo-nos em uma pequena amostra de alunos da turma (15 alunos), uma vez que o período letivo já estava sendo finalizado e boa parte dos alunos estavam dispensados.

Dessa forma, com o questionário elaborado, procuramos em uma primeira parte avaliar se a linguagem utilizada nos textos estava acessível, bem como as questões e exercícios propostos. Como resultado quanto à compreensão dos textos, 11 alunos disseram que os textos foram fáceis de compreender, sendo que para os 15 alunos os textos foram essenciais para a compreensão do conteúdo. Isso nos fornece indícios da regra $V$, mostrando que foi possível tornar os conceitos mais compreensíveis, através de uma linguagem mais acessível, de forma que o aluno pudesse compreender o novo saber. Acreditamos que essa melhor compreensão também esteja ligada às atividades elaboradas em algumas aulas, uma vez que os alunos foram capazes de executá-las e de responder às questões propostas nos roteiros.

No aspecto dos exercícios e questões, 9 alunos afirmaram que foram fáceis de ser compreendidos e entendidos. Outros 6 alunos disseram que as questões foram de dificuldade média a difícil de serem respondidos. Ainda foi bem avaliada a quantidade de exercícios propostos, que entre 10 alunos foi dada como adequada. Convém ressaltar que o fato de alguns alunos afirmarem a dificuldade na resolução das questões, deve-se ao fato que as questões elaboradas não estavam nos padrões tradicionais encontrados nos livros de física de Ensino Médio, sendo, portanto, essa dificuldade um fator esperado e totalmente tolerável nessa situação. Com isso, conseguimos transformar 0 saber em exercícios, problemas e questões, mesmo que essas questões não estejam nos moldes das comumente trabalhadas por eles nas aulas de física. Eles conseguiram respondê-las satisfatoriamente, entendendo que um novo contrato didático estava sendo proposto. 
Também foi feito um levantamento sobre a estrutura do curso, através do ponto de vista dos alunos que participaram dele, na expectativa de perceber se eles haviam notado que os assuntos discutidos nas aulas estavam ligados entre si, formando um todo coerente. Dessa forma, 10 alunos afirmaram que as aulas e o conteúdo estavam ligadas umas às outras, e 5 disseram que estavam muito ligadas, confirmando que a estrutura do curso foi percebida pelos alunos, como mostra a transcrição da resposta de alguns deles:

$\mathbf{Q}\left(\mathbf{A x}_{\mathbf{x}}\right)$ : "Os textos ajudaram na compreensão das idéias. As ilustrações também."

$\mathbf{Q}\left(\mathbf{A}_{B}\right)$ : "Gostei da teoria."

$\mathbf{Q}\left(\mathbf{A}_{\mathbf{z}}\right)$ : "As atividades não tem como esquecer. Não gostava de ler, mas os textos foram de fácil leitura na maioria das vezes."

Um aspecto importante ressaltado pelos alunos foi a diferença que 0 curso deu em relação aos anos anteriores, conforme mostra a transcrição a seguir:

$\mathbf{Q}\left(\mathbf{A}_{\mathbf{W}}\right)$ : "Foi mais proveitoso. Antes era muita teoria e pouca prática. Agora a gente fez muita coisa."

$\mathbf{Q}\left(\mathbf{A}_{\mathbf{s}}\right)$ : "Nem parecia aula de Física. O tempo passava rápido e eu nem percebia. Sempre estava prestando atenção!"

Analisando ainda o questionário, percebe-se que foi possível modernizar e atualizar o saber escolar (Regras I e II), levando uma visão mais atual da natureza dos fenômenos para a sala de aula. Essas confirmações foram constatadas quando os alunos foram questionados sobre se o seu olhar diante do mundo em que vivem sofreu alguma alteração após as discussões feitas durante o curso, onde obtivemos respostas como as seguintes:

$\mathbf{Q}\left(A_{\mathrm{w}}\right)$ : "Nem sabia que a luz era radiação. Pra mim luz era luz e pronto." $\mathbf{Q}\left(\mathbf{A}_{\mathbf{S}}\right)$ : "Achei interessante saber que a luz gerada na queima de uma simples vela tem tanta coisa de Física, ainda mais de Física Moderna." 
$Q\left(A_{B}\right)$ : "A Física nem é tão chata como eu achava. Aprendi muito nesse curso. Agora estou pensando mais nas coisas que me cercam."

No questionário ainda procuramos abordar os alunos quanto às concepções que eles tinham sobre o ensino de física e um pouco da própria física. Através disso, percebemos que a maioria afirmou que a física era uma disciplina que utilizava muito a matemática, afinal tinha muitos cálculos, mas que na maioria das vezes se tornava chata por apresentar tais cálculos de uma forma complicada, o que para eles não despertava interesse algum.

Esses aspectos apontados pelos alunos nos levaram a concluir que 0 ensino de física que eles receberam em anos anteriores foi um ensino muito tradicional, baseado em cálculos e sem a aplicação de atividades, onde uma conexão com a realidade e os objetos que eles utilizam, praticamente não acontecia. Isso se revelou também em algumas respostas, quando deixamos uma pergunta em aberto para eles fazerem os comentários que achassem necessários. Surgiram respostas como:

$\mathbf{Q}\left(\mathrm{A}_{\mathrm{W}}\right)$ : "Antes só tinham cálculos que eu não entendia. Dessa vez foi diferente."

$\mathbf{Q}\left(\mathbf{A}_{\mathbf{S}}\right)$ : "As aulas foram diferentes das aulas dos anos anteriores. Sempre tinha algo pra gente fazer."

$\mathbf{Q}\left(\mathbf{A}_{\mathbf{z}}\right)$ : "Aprendi que muita coisa na Física avançou. Minhas idéias sobre ela também avançaram."

Assim, podemos concluir que os alunos perceberam que existe uma outra forma de ensinar física, mostrando que ela pode ser mais atrativa e bem mais interessante para os alunos do Ensino Médio, e não se baseando única e exclusivamente em cálculos ou fatos totalmente desconectados da sua realidade. Também houve uma mudança na maneira deles olharem o trabalho científico e a própria ciência, mostrando que começaram a compreender que a ciência é um empreendimento humano e muito dinâmico, e ainda não acabado, como pode ser percebida na última transcrição $\left(Q\left(A_{z}\right)\right)$.

Analisando o curso como um todo e as impressões dos alunos diante do questionário, percebemos que houve uma mudança no interesse deles, no 
comportamento e na sua presença nas aulas de física, o que pode ser percebido pelo número médio de alunos durante o curso que foi sempre em torno de 35. Assim, diante de todas essas respostas e observações aqui apresentadas, acreditamos que elas reforçam ainda mais a operacionalidade e a terapêutica, indicando que o curso obteve um relativo sucesso entre os alunos e que as atividades foram possíveis de serem executadas, não sendo apresentado pelos alunos nenhum obstáculo para sua aplicação.

Convém ressaltarmos também o mérito da figura do professor que soube conduzir as aulas de forma adequada, estudando-as, adaptando-as e principalmente, fazendo-as acontecerem da forma como foram previstas. Isso mostra também que um bom planejamento, aliado a uma proposta inovadora com um material alicerçado em um conjunto de marcadores-estruturantes, preocupados também com a aprendizagem do aluno, pode ajudar a reverter o quadro atual de ensino de física nas escolas de Ensino Médio. 


\section{CONSIDERAÇÕES FINAIS}

Ao pensarmos em uma proposta de inovação curricular como esta, onde pretendemos trazer para a sala de aula tópicos de FMC, como é a Física das Radiações, certamente a maior dificuldade e preocupação seria quanto aos obstáculos relacionados à transposição dos saberes para o ambiente escolar e como estes seriam adaptados para uma linguagem mais acessível, sem que os saberes ficassem descaracterizados, daí a necessidade da vigilância epistemológica constante.

Entretanto, após a elaboração da proposta, sua aplicação e análise da seqüência didática através da Transposição Didática e suas regras, obtemos resultados que evidenciam o seu sucesso, o que pode ser identificado de diversas formas, seja pelo envolvimento que os alunos tiveram no curso, seja pelo professor que conseguiu administrar de forma adequada os momentos da aula, conduzindo-a aos objetivos previamente selecionados. Diante disso, acreditamos que através dos resultados obtidos temos um cenário promissor para que outras propostas inovadoras sejam elaboradas e possam ser legitimadas através da teoria da Transposição Didática.

Convém ressaltar que quando imaginamos a elaboração de uma proposta como esta desde o início do trabalho, focamos nossa atenção na elaboração do curso, na seleção dos conteúdos e na aplicação da Transposição Didática a esses conteúdos, procurando adaptá-los a uma linguagem acessível conforme era a proposta inicial, mantendo a vigilância epistemológica. Diante disso, outros detalhes que não julgamos interessantes ou importantes inicialmente, mostraram-se, mais tarde, consideráveis empecilhos para a aplicação da proposta.

Esses empecilhos são muitas vezes relacionados a objetos que fogem ao nosso controle, mas que acabam sendo determinantes na execução de qualquer proposta. Podemos citar como exemplo de um desses determinantes, o número de aulas de física que atualmente está disponibilizada na grade curricular para o período noturno das escolas estaduais.

Inicialmente o curso de Física das Radiações tinha uma previsão de 30 aulas. Esse número foi reconsiderado mais tarde após uma aplicação inicial da 
proposta, principalmente por motivos de adequação aos bimestres escolares. Para ser mais claro, em um bimestre escolar na rede estadual de ensino, em particular para a 3a série do Ensino Médio, tem-se geralmente um número aproximado de 20 aulas no período noturno. Caso o número de aulas inicial tivesse se mantido, teria comprometido pelo menos um bimestre e meio do ano letivo, o que em nossa visão de pesquisador, e também de professor, comprometeria o desenvolvimento de outros conteúdos que também julgamos importantes de serem trabalhados nessa série.

Outro detalhe é que pelo fato de aplicarmos a proposta em uma turma do EJA, teríamos apenas dois bimestres. Assim, optamos pela redução da carga horária do curso de Física das Radiações, readequando os conteúdos e atividades previstas, sem que esta redução afetasse diretamente a proposta de inserção desse tópico da FMC, adequando-a ao tempo disponível. Diante disso, percebemos que compete ao pesquisador ter essa sensibilidade diante de uma situação como esta, afinal em nada adiantaria usurparmos tanto tempo para um curso, comprometendo a continuidade das atividades já planejadas e programadas para o ano e o semestre letivo.

Outro detalhe que também nos evidenciou a necessidade de opção pela redução desse número de aulas do curso, foi a necessidade de aplicação da nossa proposta apenas no segundo semestre, em particular, no último bimestre, uma vez que durante o primeiro foi feita a discussão de conceitos básicos da Física Clássica, como os presentes na Eletricidade e no Magnetismo, conceitos estes que serviriam de subsídio para a implementação do curso de Física das Radiações. Portanto, mesmo com a aplicação da proposta, os alunos do Ensino Médio acabaram tendo contato com os conceitos da Física Clássica, mesmo que reorganizados e focalizados para a aplicação do curso de Física das Radiações.

Por outro lado, percebemos que de fato restaram apenas dois bimestres para a aplicação da proposta e, conhecendo a realidade escolar, sabemos que existem ainda outros momentos programados e outros nem tanto programados, que acabam atrapalhando a continuidade das aulas, o que chamamos de empecilhos anteriormente. Durante a aplicação da proposta, constatamos outros empecilhos como festas, passeios, conselhos de classe, reuniões com pais e conselhos de escola. Assim, nossa opção pela redução do número de 
aulas foi feita de maneira consciente e coerente com o cotidiano escolar, mostrando que a sensibilidade daquele que elabora a proposta sempre deve estar em atividade.

Entretanto, analisando o curso, sua aplicação e os eventuais empecilhos que relatamos, percebemos que não tivemos dificuldades em criar a motivação para que os alunos estudassem a Física das Radiações, acreditando que acertamos na elaboração das atividades e textos, ou seja, que os instrumentos que foram elaborados conseguiram promover a aprendizagem dos conceitos previamente definidos. Acreditamos que as atividades com um caráter investigativo ou de situações-problema acabaram promovendo o envolvimento tão esperado dos alunos nas discussões e participações nas aulas o que, do ponto de vista dos conceitos, fizeram-se mais compreensíveis apesar de sua complexidade, o que certamente conduziu para uma aprendizagem mais significativa.

Ao falarmos de aprendizagem, embora esse fator não tenha sido o foco desta pesquisa, podemos inferir que não houve grandes dificuldades que pudessem impedir o acompanhamento e o desenvolvimento das aulas. Foi perceptível que as dificuldades apresentadas durante a execução da proposta não foram muito diferentes daquelas presentes no aprendizado da Física Clássica, ou que elas não tenham se manifestado tanto devido à grande motivação que os alunos tiveram para estudar os conceitos e participar das atividades e discussões em sala.

Podemos concluir que foi possível levar a proposta do curso de Física das Radiações para os alunos do Ensino Médio, mesmo que estes fossem da modalidade EJA. Apesar do assunto ser considerado complexo, foi possível fazer uma adaptação para que fosse alcançado pelos alunos. Possivelmente, se a proposta fosse aplicada em turmas do regular com um tempo maior de aula e com a disponibilidade de programar a inserção da proposta no ano letivo, e não somente no semestre letivo, podemos inferir que os resultados ainda seriam melhores e com maior riqueza de detalhes, ficando essa possibilidade em aberto para futuras constatações.

Embora não tenhamos analisado todo o curso e suas atividades, cremos que toda a seqüência ficou bem estruturada, permitindo futuras aplicações para que possa vir a confirmar a nossa hipótese. Talvez não demore para poder 
colher tais respostas, uma vez que todo o material dessa proposta se encontra disponível no site do NUPIC (Núcleo de Pesquisas e Inovações Curriculares), hospedada na incubadora da FAPESP (Fundação de Amparo à Pesquisa do Estado de São Paulo), no seguinte endereço:

- http://nupic.incubadora.fapesp.br/portal/projetos/fisica-oderna/radiacoes-1/.

Também podemos destacar como sendo um outro fator positivo e de sucesso da nossa proposta, o aspecto relacionado com a abordagem, conforme foi apresentado no capítulo de introdução. Chegamos naquela oportunidade à conclusão de que não existe um consenso na comunidade de pesquisadores em ensino de física quanto à qual abordagem seria a mais razoável para a inserção da FMC na sala de aula. Entretanto, ao utilizar a abordagem fenomenológica, obtivemos sucesso com o conteúdo da Física das Radiações, pois quando um fenômeno é trazido para discussão em sala de aula, através de uma atividade, o conceito que se quer ensinar torna-se mais significativo para os alunos, o que pode ser visto quando Arons (1990) defende que alguns conceitos de FMC devam ser ensinados no Ensino Médio, tendo como objetivo levar alguma percepção aos alunos sobre conceitos modernos e contemporâneos, sendo que a Física Clássica poderia estar inserida na perspectiva de um suporte para a apresentação desses conceitos da FMC.

Nosso trabalho também nos mostrou que é possível superar os principais obstáculos apontados pela literatura referente à inserção da FMC, que se manifestaram em nossa proposta. O primeiro obstáculo encontrado foi a questão do material didático apropriado para os alunos e para os professores. Foi possível superá-lo com a confecção de material adequado tanto para o aluno quanto para o professor, de tal maneira que fugisse dos modelos dos livros didáticos tradicionais. Para isso, a Física das Radiações não foi resumida em poucas páginas ou conceitos desconectados da realidade, sendo desenvolvida de forma a estabelecer um encadeamento lógicos das idéias, o que facilitou a sua compreensão, enquanto que o segundo obstáculo foi referente às atividades. Assim, elas tornaram-se ponto chave da proposta, tornando-se alicerces da mesma, daí materializando o que chamamos de marcadores-estruturantes do curso de Física das Radiações.

Dessa forma, o caráter investigativo das atividades permitiu que os alunos as executassem de maneira dinâmica e interativa, não admitindo uma 
postura passiva e tão comum, como observamos nas salas de aula. Tivemos, então, que buscar atividades práticas que pudessem dar esse caráter dinâmico ao curso, o que concluímos que foi alcançado pelos resultados obtidos. Logo, as atividades tiveram também uma contribuição relevante na discussão dos conceitos durante as aulas, pois as analogias que foram criadas puderam esclarecer mais os conceitos, auxiliando no aprendizado dos alunos, o que foi uma indicação de que foi possível gerar uma criatividade didática, no sentido da Transposição Didática.

Um outro obstáculo encontrado na aplicação da proposta foi quanto à preocupação com a formação do professor que viria a desenvolver o curso para o trabalho desta pesquisa, uma vez que grande parte dos docentes desconhecem os conceitos trabalhados nessa área da física. Assim, para o professor que faria a aplicação desta proposta, recorremos a sua capacitação ao longo da aplicação da proposta, o que ocorria sempre às terças-feiras no próprio laboratório do LAPEF. Isso permitiu um melhor acompanhamento do curso e da execução das atividades.

Finalmente, conseguimos romper com o obstáculo referente ao formalismo matemático optando pela abordagem fenomenológica, na qual conseguimos adaptar toda a descrição matemática em conceitos que pudessem ter o rigor bem próximo daqueles utilizados pelas equações, porém discutindo vários fenômenos sem a necessidade de apelação para uma matemática mais rebuscada. Acreditamos que a linguagem matemática é de extrema importância para que os estudantes do Ensino Médio também possam quantificar os fenômenos observados na física, mas optamos pelo não uso desta linguagem, ou melhor, optamos por reduzir o seu emprego durante a nossa proposta de forma que a compreensão dos conceitos fossem a nossa principal preocupação.

Portanto, podemos afirmar que sempre existirão obstáculos a serem transpostos na busca por atualizações curriculares. Contudo, são possíveis de serem superados, iniciando com um mapeamento prévio das dificuldades, o trabalho colaborativo com os professores do Ensino Médio e o suporte de um referencial teórico para elaboração e avaliação das atividades. Quanto aos alunos que se envolveram com a proposta, certamente ela trouxe uma motivação a mais para que eles estudassem mais a física, pois perceberam 
que ela não se resume a cálculos, mas sim à discussão de conceitos, contribuindo para uma concepção mais realista da Ciência Contemporânea e do trabalho científico, sem contar com a formação de um aluno mais crítico, participativo e consciente das discussões acerca da Ciência Contemporânea.

Outro aspecto importante da pesquisa foi o uso da Transposição Didática. Acreditamos que através dela foi possível realçar as nuances da proposta, analisando toda a adaptação feita durante a elaboração e aplicação do curso. Essa teoria pode-se tornar um referencial didático para análise de novas propostas de ensino. Isso porque esse instrumento conseguiu apontar que as transformações ocorridas no saber são possíveis ou não de serem realizadas para que, de fato, se torne um "saber de sala de aula". Com isso, a Transposição Didática foi capaz de mostrar que, para o nosso caso, a Física das Radiações pode se tornar um saber de sala de aula, validando a nossa seqüência didática.

A partir de tudo que foi exposto acima, podemos afirmar que foi possível elaborar uma proposta de ensino sobre a Física das Radiações, aplicá-la em condições reais em sala de aula para que fosse validada, o que nos deixou mais satisfeitos. Particularmente, me senti muito gratificado por ver que a minha proposta pôde se concretizar em um trabalho com excelentes resultados, possibilitando a minha melhor formação como professor e pesquisador em educação, além de possibilitar que outros professores, com este material, possam ter resultados tão satisfatórios como os meus e alunos mais motivados e conscientes do mundo em que estão inseridos. 


\section{REFERÊNCIAS BIBLIOGRÁFICAS}

ALVES-FILHO, José P. Atividades Experimentais: Do método à Prática Construtivista. Tese de Doutorado, UFSC, Florianópolis, 2000a. - Regras da Transposição Didática Aplicada ao Laboratório Didático. Caderno Catarinense de Ensino de Física, Florianópolis, V.17, n.2, p.174-188, ago. 2000b.

ALVETTI, M. A. S. Ensino de física moderna e contemporânea e a revista ciência hoje. 1999. Florianópolis: curso de pós-graduação em educação e ciências - Universidade Federal de Santa Catarina, 1999. Dissertação de mestrado.

ARONS, A. B. A guide to introductory physics teaching. New York: John Wiley, 1990.

ASTOLFI, Jean Pierre et al. Mots-clés de la didactique des sciences. Pratiques Pèdagogies. Bruxelas: De Boeeck \& Larcier S. A., 1997.

ASTOLFI, Jean Pierre e DEVELAY, Michel. A Didática das Ciências. $10^{\underline{a}}$ ed. Campinas: Papirus, 2002.

BRASIL. Leis, Decretos etc. Decreto n. 2.208/97. . Leis, Decretos etc. Lei de Diretrizes e Bases da Educação Nacional n. 9.394/96. Parecer n. 15/98.

BRASIL. MEC. Secretaria de Educação Média e Tecnológica. Parâmetros Curriculares Nacionais: Ensino Médio. Brasília: Ministério da Educação, 1999. 
BRASIL. Ministério da Educação. PCN+ Ensino Médio: Orientações Educacionais Complementares aos Parâmetros Curriculares Nacionais para o Ensino Médio. Ciências da Natureza, Matemática e suas tecnologias. Brasília: Ministério da Educação/Secretaria de Educação Média e Tecnológica, 2002.

BOGDAN, R. BIKLEN, S. Investigação Qualitativa em Educação. Uma introdução à teoria e aos métodos. Porto: Porto Editora, 1982.

BROCKINGTON, Guilherme. A Realidade escondida: a dualidade ondapartícula para alunos do Ensino Médio. São Paulo: curso de pós-graduação em ensino de Ciências - USP, 2005. Dissertação de mestrado.

BROUSSEAU, G. Fondements et méthodes de la didactique des mathematiques. Recherches em Didactique des Mathématiques, v. 7, n. 2, Grenoble, 1986.

CAMARGO, A. J. A introdução da física moderna no $2^{\circ}$ grau: Obstáculos e possibilidades. Florianópolis: curso de pós-graduação em educação - UFSC, 1996. Dissertação de Mestrado.

CANATO, Osvaldo. Texto e contexto para o ensino de Física Moderna e Contemporânea na escola média. São Paulo: IF/FE USP, 2003. Dissertação de mestrado.

CAPECCHI, M. C. V. M.; CARVALHO, A. M. P.. Interações discursivas na construção de explicações para fenômenos físicos em sala de aula. VII Encontro de Pesquisa em Ensino de Física, Florianópolis, 2000.

CARVALHO, A. M. P, GIL-PEREZ, D. Formação de professores de ciências. São Paulo: 6ª ed. Cortez, 2001. 
CARVALHO, A. M. P. Critérios Estruturantes para o Ensino das Ciências. Ensino de Ciências: unindo a pesquisa e a prática. São Paulo: Pioneira Thomsom Larning, 2004.

CARVALHO, A. M. P.; VANNUCHI, Andréa. O currículo de Física: inovações e tendências nos anos noventa. Investigações em Ensino de Ciências. Porto Alegre: V.1, n.1, p.3-19, abr. 1996.

CHEVALLARD, Yves. La Transposicion Didactica: Del saber sabio al saber enseñado. Argentina: La Pensée Sauvage,1991.

CHEVALLARD, Y., JOSHUA, M. A. Un exemple de la transposition didactique: la notion de distance. Recherches en Didactique des Mathématiques, v.3, n. 1, p. 159-239, La Pensée Sauvage Editions, 1982.

FERREIRA, Andréia Alves. Ensino de Física das Radiações na modalidade EJA: Uma proposta. São Paulo: IF/FE USP, 2004. Dissertação de mestrado.

FISCHLER, H.; LICHTFELDT, M. Modern physics and students' conceptions. International Journal of Science Education, Londres, v. 14, n. 2, p. 181-190, 1992.

GIL. D. P., SENENT, F., SOLBES, J. La introducción a la Física Moderna: um ejemplo paradigmatico de cambio conceptual. Enseñanza de las Ciências. Barcelona: p.209-210, n. Extra, set. 1987.

GONÇALVES, M. E. R. As atividades de Conhecimento Físico na Formação do Professor das Séries Iniciais. São Paulo: curso de pósgraduação em Educação - FEUSP, 1997. Tese de Doutorado.

GRECA, lleana Maria; MOREIRA, Marco Antônio. Uma revisão da literatura sobre estudos relativos ao ensino da mecânica quântica introdutória. Investigação em ensino de ciência. Porto Alegre: V.6, N.1, março de 2001. 
LÜDKE, Menga; ANDRÉ, Marli E. D. A. Pesquisa em educação: abordagem qualitativa. São Paulo: EPU, 1986.

MACHADO, D. I. Construção de conceitos de física moderna e sobre a natureza da ciência com o suporte da hipermídia. Bauru: pós-graduação em educação para a Ciência - Universidade Estadual de São Paulo, 2006. Dissertação de Mestrado.

MACHADO, D. I., NARDI, R. Avaliação do Ensino da Física Moderna e Contemporânea no Ensino Médio. In: Encontro Nacional de Pesquisa em Educação em Ciências, IV, Atas... Bauru, 25 a 29 de nov. de 2003, paginação eletrônica, CD-ROM.

MARTINS, Gilberto de Andrade. Estudo de Caso: uma estratégia de pesquisa. São Paulo: ATLAS, 2006.

MARTINS, R. A.. A Física no final do século XIX: modelos em crise. Atas: XII Simpósio Nacional de Ensino de Física, Belo Horizonte, 1997.

MOZENA, E. R.. A solução de Planck para o problema da radiação do corpo negro (PRCN) e o ensino da física quântica. São Paulo: IF/FE USP, 2003. Dissertação de mestrado.

OLIVEIRA, Fabio F.. O Ensino da Física Moderna com Enfoque CTS: Uma proposta metodológica para o Ensino Médio usando o tópico raios-X. Rio de Janeiro: FE UFRJ, 2006. Dissertação de mestrado.

OSTERMANN, Fernanda. Um texto para professores do ensino médio sobre partículas elementares. Revista Brasileira de Ensino de Física. V.21, n.3, p.415-436, set 99 .

OSTERMANN, Fernanda; MOREIRA, Marco Antonio. Atualização do currículo de Física na escola de nível médio: um estudo desta problemática na perspectiva de uma experiência em sala de aula e da formação inicial de 
professores. 2000. Trabalho apresentado no VII Encontro de Pesquisa em Ensino de Física, Florianópolis, 2000a.

Física Contemporânea en la escuela secundaria: uma experiência em el aula involucrando formación de profesores. Enseñanza de las Ciências, Barcelona, v. 3, n. 18, p. 391-404, 2000b.

Uma revisão bibliográfica sobre a área de pesquisa "Física Moderna e Contemporânea no Ensino Médio". Porto Alegre: Investigações em Ensino de Ciências, 2000c, v. 5, n. 1.

OSTERMANN, Fernanda; CAVALCANTI, Cláudio. Física Moderna e Contemporânea no ensino médio: elaboração de material didático, em forma de pôster, sobre partículas elementares e interações fundamentais. Caderno Catarinense de Ensino de Física. Florianópolis, V.16, n.3, p.267-286, dez.99.

PINHEIRO, T. F.; PIETROCOLA, M.; ALVES-FILHO, J. Fo. Modelização de variáveis: uma maneira de caracterizar o papel estruturante da matemática no conhecimento científico. Ensino de Física: conteúdo, metodologia e epistemologia numa concepção integradora. Pietrocola, M. (org.). Florianópolis: Editora UFSC/INEP, 2001.

PINTO, A.C., ZANETIC, J. É possível levar a física quântica para o ensino médio? Caderno Catarinense de Ensino de Física. Florianópolis: V.16, n.1, p.7-34, abril 99.

RODRIGUES, Carlos Daniel Ofugi. Inserção da Teoria da relatividade no ensino médio: Uma nova proposta. Florianópolis: curso de pós-graduação em educação - UFSC, 2001. Dissertação de Mestrado.

SILVA, Walkiria Reche da. Inserção de tópicos da nova física da estrutura da matéria no ensino médio: uma proposta. São Paulo: curso de pósgraduação em ensino de ciências - USP, 2002. Dissertação de Mestrado. 
SIQUEIRA, Maxwell. Do visível ao indivisível: uma proposta de Física de Partículas Elementares para o Ensino Médio. São Paulo: IF/FE USP, 2006. Dissertação de mestrado.

SIQUEIRA, Maxwell; PIETROCOLA, Mauricio. A Transposição Didática aplicada a Teoria Contemporânea: A Física de Partículas no Ensino Médio. X Encontro Nacional de Pesquisa em Ensino de Física. Londrina, 2006.

TEIXEIRA, A.; KRAPAS, S. Reflexões sobre a Transposição Didática da Lei de Coulomb. Enseñanza de las Ciências, Barcelona, 2005. Número Extra. VII CONGRESO.

TERRAZZAN, Eduardo A. A inserção da Física Moderna e Contemporânea no Ensino de Física na escola de $2^{\circ}$ grau. Caderno Catarinense de Ensino de Física. Florianópolis, V.9, n.3, p.209-214, dez.1992.

TERRAZZAN, Eduardo A. Perspectivas para a inserção de física moderna na escola média. São Paulo: curso de pós-graduação em educação - USP, 1994. Tese de Doutorado.

TERRAZZAN, Eduardo A., et al. A evolução das idéias sobre a estrutura da matéria: uma contribuição para o ensino de Física. Atas: XII Simpósio Nacional de Ensino de Física, Belo Horizonte, p.650-658, jan. 1997.

TRIVIÑOS, A. N. S. Introdução à Pesquisa em Ciências Sociais. $1^{\text {a }}$ ed. São Paulo: ed. Atlas, 1987.

USBERSCO, A.; SALVADOR, B. Química Geral. 15 Saraiva, 2008.

VALADARES, E. C., MOREIRA, A. M. Ensinando Física Moderna no segundo grau: efeito fotoelétrico, laser e emissão de corpo negro. Caderno Catarinense de Ensino de Física, Florianópolis, v. 15, n. 2, ago 1998, p. 121-135. 
Partículas e interações. Revista A Física na escola, V.5, n.2, p.10-14, out 2004.

\section{Sites:}

http://cienciahoje.uol.com.br. Acesso em 22/09/2009

http://www.if.ufrgs.br/cref/radio/indexe.htm. Acesso em 22/09/2009

http://portal.cbpf.br/index.php?page=divulgacao.projdidaticos. Acesso em 22/09/2009

http://nupic.incubadora.fapesp.br/portal/projetos/fisica-oderna/radiacoes-1/. Acesso em 22/09/2009 


\section{BIBLIOGRAFIA}

ABDALLA, Maria Cristina. 0 discreto charme das partículas elementares. São Paulo: Unesp, 2006.

ALVARENGA, Beatriz in: CARUSO, Francisco; SANTORO, Antonio. Do átomo grego à Física das interações fundamentais. Rio de Janeiro. AIAFEX, p.179196, 2ª edição, 2000.

ALVARENGA, Beatriz; MÁXIMO, Antônio. Curso de Física. 5aa ed., V.3. São Paulo: Scipione, 2000.

Curso de Física. 5ª ed., V.2. São Paulo: Scipione, 2000.

ALVES, Gilson; CARUSO, Francisco; FILHO, Hélio da Motta; SANTORO, Alberto. $O$ mundo das partículas de hoje e de ontem. Rio de Janeiro: CBPF, 2000.

AMALDI, Ugo. Imagens da Física - As idéias e as experiências do pêndulo aos quarks. São Paulo: Scipione, 1995.

BARRETO, Jorge L. V. A descoberta do nêutron. p 151-160. In: Partículas elementares: 100 anos de descobertas. CARUSO, F.; OGURI, V.; SANTORO, A. (org.) Manaus: Editora da Universidade Federal do Amazonas, 2005.

BIRAL, Antônio R. Radiações lonizantes para médicos, físicos e leigos. $1^{\text {a }}$ ed. Florianópolis: Editora Insular, 2002.

BONJORNO, J. R.; BONJORNO, R. A.; BONJORNO, V.; RAMOS, C. M. Física: História \& Cotidiano. São Paulo: FTD, 2004.

CARUSO, Francisco; SANTORO, Alberto. Do átomo Grego à Física das interações fundamentais. $2^{\underline{a}}$ ed. Rio de Janeiro: AIAFEX, 2000. 
CAVALCANTE, Marisa A. O ensino de uma NOVA FíSICA e o exercício da cidadania. Revista Brasileira de Ensino de Física, V.21. n.4, p.550-551, dez. 1999.

CAVALCANTE, Marisa A.; TAVOLARO, Cristiane R. C.. Uma oficina de Física Moderna que vise a sua inserção no Ensino Médio. Caderno Catarinense de Ensino de Física. Florianópolis, V.18, n.3, p.298-316, dez. 2001.

CRUZ, F. F. de S. Radioatividade e o acidente de Goiânia. Caderno Catarinense de Ensino de Física, Florianópolis, v.4, n.3, p. 164-169, dez. 1987.

DELIZOICOV, D.; ANGOTTI, J. A. Metodologia do ensino de ciências. São Paulo: Editora Cortez, 2002.

FAGUNDES, M. Beatriz. Ensinando a dualidade onda-partícula sob uma nova óptica. São Paulo, curso de pós-graduação em ensino de Ciências USP, 1997. Dissertação de Mestrado.

FELTRE, Ricardo. Química. 5ª ed., V.1. São Paulo, Moderna, 2000.

Química. 5ª ed., V.3. São Paulo, Moderna, 2000.

FERRARO, Nicolau Gilberto; SOARES, Paulo Antônio de Toledo. Física básica. $2^{\text {a }}$ ed. São Paulo: Atual, 2004

FEYNMAN, Richard P. QED: A estranha teoria da luz e da matéria. $1^{\text {a }}$ ed. Lisboa: Gradiva, 1988.

FREIRE JR, Olival; CARVALHO NETO, Rodolfo Alves. O universo dos quantas: uma breve história da física moderna. São Paulo: FTD, 1997. 
GASPAR. Alberto. Física - Eletromagnetismo e Física Moderna. $1^{\text {a }}$ ed, V.3. São Paulo: Ática, 2001

GONÇALVES FILHO, A.; TOSCANO, C. Física para o Ensino Médio. São Paulo: Scipione, 2002.

GUALTER, José Biscuola et alli. Tópicos de Física 3. 15 $15^{\mathrm{a}}$ ed. São Paulo: Saraiva, 2001.

GUTIÉRREZ, Elena Ester, et al. Qué Piensan los Jóvenes sobre Radiactividade, Estructura Atómica y Energía Nuclear? Enseñanza de las Ciências, Barcelona, v.18, n. 2, p. 247-254, 2000.

GUZZO, Marcelo; NATALE, Adriano. Introduzindo os neutrinos. p.193-208. In: Partículas elementares: 100 anos de descobertas. CARUSO, F.; OGURI, V.; SANTORO, A. (org.). Manaus: Editora da Universidade Federal do Amazonas, 2005.

HALLIDAY, David e RESNICK, Robert. Fundamentos de física. 3. ed. Rio de Janeiro: Livros Técnicos e Científicos, 1994. v 4.

HANLEY, Phil. Teaching Particle Physics. Physics Education, v.35, n. 5, sept. 2000.

HARVARD PROJECT PHYSIC. Unidade Suplementar A. Partículas elementares. Lisboa: Fundação Calouste Gulbenkian, 1987.

HEWITT, Paul. Física Conceitual. 9aㅗ ed. Porto Alegre: Bookman, 2002.

KUHN, T. A estrutura das revoluções científicas. Perspectiva, $8^{a}$ ed. São Paulo: 2003.

MARINELLI, J. R. Enxergando o Núcleo atômico. Caderno Catarinense de Ensino de Física, Florianópolis, v.6, n. 3, p. 234-240, dez. 1989. 
MARTINAND, J. L. Connaître et Transformer la Matière. Berna: Peter Lang, 1986.

MENEZES, Luis Carlos de. A matéria uma aventura do espírito: fundamentos e fronteiras do conhecimento físico. São Paulo: Livraria da Física, 2005.

MENEZES. Luís Carlos; HOSOUME, Yassuko. Para lidar com o mundo real, a Física escolar também precisa ser quântica. Atas: XII Simpósio Nacional de Ensino de Física, Belo Horizonte, p.282-230, jan. 1997.

MONTEIRO, M. A., NARDI, R. Tendências das pesquisas sobre o ensino da Física Moderna e Contemporânea. Atas: Encontro Nacional de Pesquisa em Educação em Ciências, VI. Florianópolis, 2007, paginação eletrônica, CDROM.

MOTTA, Hélio da. O próton. p.123-131. In: Partículas elementares: 100 anos de descobertas. CARUSO, F.; OGURI, V.; SANTORO, A. (org.). Manaus: Editora da Universidade Federal do Amazonas, 2005.

NARDI, R. (Org.). Pesquisas em Ensino de Física. 2. ed. rev. São Paulo: Escrituras, 2003.

NICOLAU, G. F.; PENTEADO, P. C.; TOLEDO, P. S.; TORRES, C. M. Física ciência e tecnologia. São Paulo: Moderna, 2001.

OKUNO, Emico. Radiação: Efeitos, riscos e benefícios. $1^{\text {a }}$ ed. São Paulo: Editora Harbra, 1998.

OKUNO, Emico; VILELA, Maria A. C. Radiação Ultravioleta: Características

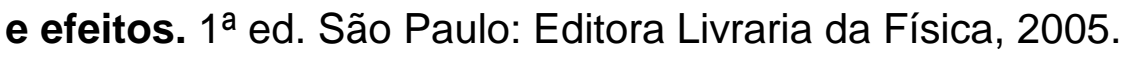

OKUNO, E; CALDAS, I.L.; CHOW, C. Física para Ciências Biológicas e Biomédicas. Editora Harbra, São Paulo, 1986. 
PEREIRA, O. da S. Raios Cósmicos: introduzindo física moderna no 2o grau. São Paulo: Instituto de Física e Faculdade de Educação - USP, 1997, Dissertação de Mestrado em Ensino de Ciências.

PEREIRA, O. S. Visão de estudantes sobre a inserção de Física Moderna e Contemporânea no $2^{\circ}$ grau. Atas: XII Simpósio Nacional de Ensino de Física. Belo Horizonte, p.551-558, jan. 1997.

PIETROCOLA, Maurício et al. A perturbação do contrato didático e o gerenciamento dos paradoxos. Investigações em Ensino de Ciências. Porto Alegre, V.8, n.3, ago/2002.

PINHEIRO, T. F.; PIETROCOLA, M.; ALVES-FILHO, J. P. Modelização de variáveis: uma maneira de caracterizar o papel estruturante da matemática no conhecimento científico. Ensino de Física: conteúdo, metodologia e epistemologia numa concepção integradora. Pietrocola, M. (org.). Editora UFSC/INEP, Florianópolis, 2001.

PINTO, A.C., ZANETIC, J. É possível levar a física quântica para o ensino médio? Caderno Catarinense de Ensino de Física, Florianópolis, V.16, n.1, p.7-34, abril 99.

RAMALHO JR., Francisco; FERRARO, Nicolau Gilberto; SOARES, Paulo Antônio de Toledo. Os fundamentos da Física. 7 ed. São Paulo: Moderna, 1999.

REZENDE JUNIOR, Mikael Frank; SOUZA CRUZ, Frederico Firmo. Física Moderna e Contemporânea no Ensino Médio: Do consenso de temas à elaboração de propostas. Atas: IV Encontro Nacional de Pesquisa em Educação em Ciências. Bauru, 2003.

ROBILOTTA, M. R. Construção e Realidade no ensino de Física. São Paulo: monografia, IFUSP, 1985. 
ROBILOTTA, M. R.; BABICHAK, C. C. Definições e conceitos em Física. Cadernos Cedes. Ano XVIII, p.35-61, n.41, jul 1997.

SALMERON, Roberto A. Física Nuclear, raios cósmicos e as origens da Física de Partículas. In: Partículas elementares: 100 anos de descobertas. CARUSO, F.; OGURI, V.; SANTORO, A. (org.). Manaus: Editora da Universidade Federal do Amazonas, 2005.

SAMPAIO, José Luiz; CALÇADA, Caio Sérgio. Física. V. único. São Paulo: Atual, 2003.

SEGRÉ, E. Dos raios $\mathrm{X}$ aos Quarks: Físicos Modernos e suas Descobertas. Brasília: ed. da Universidade de Brasília, 1982.

SWINBANK, E. Particle Physics: a new course for schools and colleges. Physics Education, v. 27, n. 2, p. 87-91, mar. 1992.

TERRAZZAN, Eduardo A. A inserção da Física Moderna e Contemporânea no Ensino de Física na escola de $2^{\circ}$ grau. Caderno Catarinense de Ensino de Física. Florianópolis, V.9, n.3, p.209-214, dez.1992.

TIPLER, Paul A.; LLEWELLYN, Ralph A. Física Moderna. $3^{\text {a }}$ ed. Rio de Janeiro: LTC, 2001.

VARELA, João. O século dos quantas. Lisboa: Gradiva, nov 96. 


\author{
Universidade de São Paulo \\ Instituto de Física - Instituto de Química \\ Instituto de Biociências - Faculdade de Educação
}

\title{
Física das Radiações: Uma proposta para o Ensino Médio
}

\author{
Wellington Batista de Sousa
}

\section{ANEXOS}

Orientador: Prof. Dr. Elio Carlos Ricardo

\begin{abstract}
Dissertação de mestrado apresentada ao Instituto de Física, ao Instituto de Química, ao Instituto de Biociências e a Faculdade de Educação da Universidade de São Paulo, para a obtenção do título de Mestre em Ensino de Ciências.
\end{abstract}

Comissão Examinadora:

Prof. Dr. Elio Carlos Ricardo (Orientador) - USP

Profa. Dra. Jesuína Lopez de Almeida Pacca - USP

Prof. Dr. Mikael Frank Rezende Junior - UNIFEI

São Paulo

2009 
Durante a elaboração do curso de Física das Radiações, procuramos dividi-lo em quatro blocos de forma a organizar melhor a proposta conforme a carga horária disponível. Assim, o material ficou com uma previsão de 19 aulas para serem cumpridas durante um bimestre do ano letivo, preferencialmente após as discussões sobre os conceitos básicos da Física Clássica que envolvem a eletricidade e o magnetismo.

A organização do material está apoiada nos seguintes elementos:

- Textos: em uma linguagem acessível propiciam a formalização dos conceitos trabalhados em aula;

- Atividades experimentais: com caráter investigativo em sua maioria, propiciam um envolvimento dos alunos nos conteúdos relacionados ao tema;

- Questões e problemas: permitem a fixação e sistematização do conteúdo;

- Recursos visuais: PowerPoint, vídeos e outras multimídias que permitem a fixação ou visualização dos conceitos discutidos em aula.

A seguir, segue o material do curso de Física das Radiações que foi utilizado durante a aplicação da proposta e que pode ser encontrado no seguinte endereço: http://nupic.incubadora.fapesp.br/portal/projetos/fisica-oderna/radiacoes-1/. 


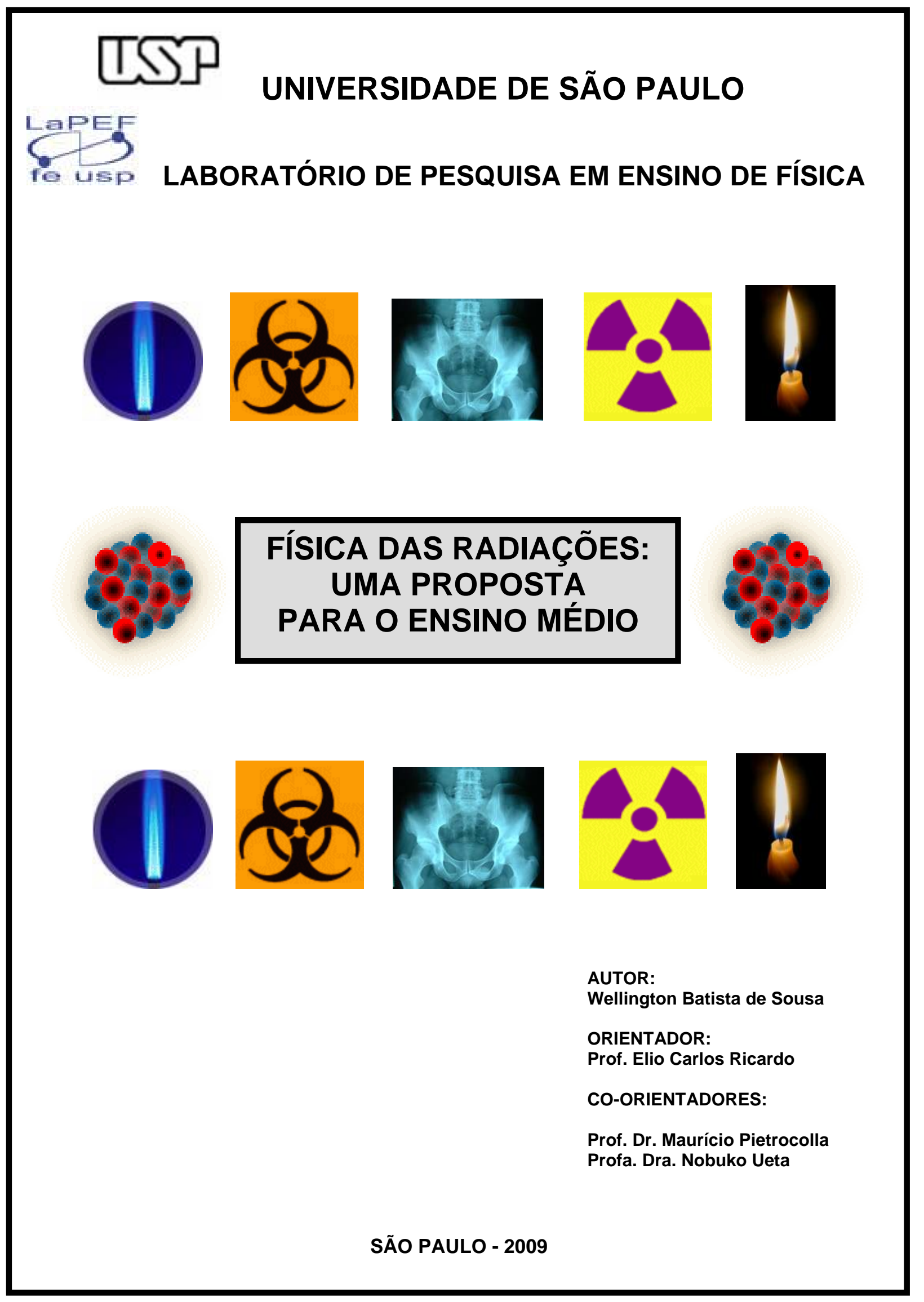




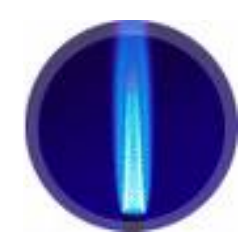

\section{CONTEÚDO}

\begin{tabular}{||l|c|}
\hline \multicolumn{2}{|c|}{ FÍSICA DAS RADIAÇÕES: } \\
UMA PROPOSTA PARA O ENSINO MÉDIO \\
\hline \hline \multicolumn{1}{|c|}{ BLOCOS } & $\begin{array}{c}\text { Quantidade } \\
\text { de Aulas }\end{array}$ \\
\hline 1- Radiações Eletromagnéticas & 8 \\
\hline 2- Radiações Corpusculares & 5 \\
\hline 3- Interação das Radiações com a Matéria e seus Efeitos & 3 \\
\hline 4- Detectores de Radiação & 3 \\
\hline \multicolumn{1}{|c|}{ Número total de aulas } & 19 \\
\hline
\end{tabular}




\section{DIVISÃO DOS BLOCOS}

FÍSICA DAS RADIAÇÕES: UMA PROPOSTA PARA O ENSINO MÉDIO

\section{Bloco 1 - Radiações eletromagnéticas}

Neste bloco pretende-se primeiramente fazer uma distinção entre os tipos de radiações (eletromagnéticas e corpusculares). Em seguida são discutidos os vários tipos de radiações eletromagnéticas (ondas de rádio, microondas, raios infravermelhos, luz visível, raios ultravioleta, raios $X$ e raios gama), suas características e aplicações.

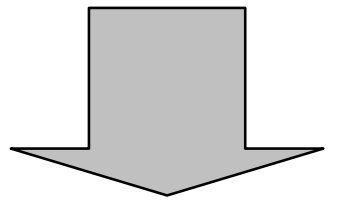

\section{Bloco 2 - Radiações corpusculares}

Neste bloco pretende-se discutir os vários tipos de radiações corpusculares, ou seja, aquelas constituídas por partículas elementares (partículas alfa, prótons, elétrons, pósitrons e nêutrons), suas características e aplicações.

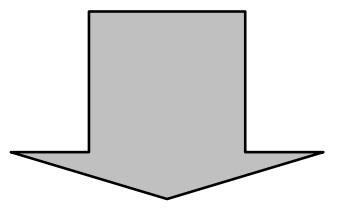

\section{Bloco 3 - Interação das radiações com a matéria e seus efeitos}

Neste bloco pretende-se fazer uma discussão sobre a diferença entre as radiações ionizantes e não-ionizantes, bem como a caracterização dos efeitos de cada uma dessas radiações ao interagirem com a matéria.

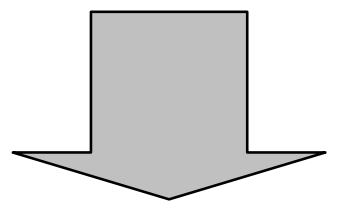

\section{Bloco 4 - Detectores de radiação}

Neste bloco pretende-se fazer uma discussão sobre os tipos de detectores de radiação que o homem construiu, como por exemplo, o Contador Geiger e o Cintilômetro, e aqueles que nós dispomos naturalmente. 


\section{CONTEÚDO RESUMIDO DO CURSO DE FÍSICA DAS RADIAÇÕES}

Bloco 1: Radiações Eletromagnéticas (8 Aulas)

Texto 0 - Apresentação do Curso

Texto 1 - Conhecendo as Radiações

Texto 2 - Espectro Eletromagnético (Introdução)

Texto 3 - Espectro Eletromagnético (Parte 1)

Texto 4 - Espectro Eletromagnético (Parte 2)

Texto 5 - Espectro Eletromagnético (Parte 3)

Texto Suplementar - A Descoberta dos Raios X
Atividade 1 - Questionário Inicial

Atividade 2 - Análise da Chama de uma Vela

Atividade 3 - Demonstração do Transmissor de Ondas

Eletromagnéticas

Atividade 4 - Dispersão da Luz

Atividade 5 - Analisando Radiografias

Bloco 2: Radiações Corpusculares (5 Aulas)

Texto 6 - Caracterizando o Átomo

Texto 7 - A Interação Nuclear e a Estabilidade do Núcleo

Texto 8 - Compreendendo os Decaimentos

Radioativos

Texto Suplementar - A Descoberta da

Radioatividade e das Radiações

Atividade 6 - Cortando papel e Potência de Dez

Atividade 7 - A Tabela Periódica e seus Elementos Radioativos

Bloco 3: Interação das Radiações com a Matéria e seus Efeitos (3 Aulas)

Texto 10 - Interação da Radiação com a Matéria e seus Efeitos
Atividade 8 - Radiação-Matéria (Hiroshima e Incrível Hulk: trechos de vídeos)

Bloco 4: Detectores de Radiação (3 Aulas)

Texto 11 - Detectores de Radiação

Atividade 9 - Papel Fotográfico 
Física das Radiações: Uma Proposta para o Ensino Médio 


\section{QUADRO SINTÉTICO}

\section{Bloco 1 - Radiações Eletromagnéticas}

\begin{tabular}{|c|c|c|c|}
\hline \multirow{10}{*}{ 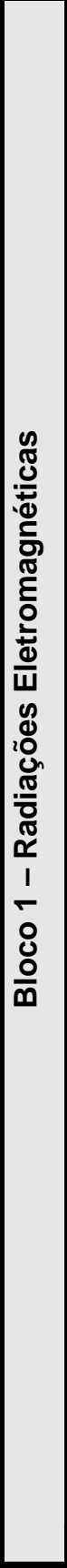 } & ATIVIDADE(S) & MOMENTOS & TEMPO \\
\hline & $\begin{array}{l}\text { 1. Questionário inicial e análise da } \\
\text { chama de uma vela. }\end{array}$ & \begin{tabular}{|l|} 
Propor e explicar o conteúdo do curso. \\
(10 min) \\
Atividade 1 - Questionário Inicial. (10 min) \\
Atividade 2 - Análise da Chama de uma Vela. \\
( 25 min) \\
\end{tabular} & 1 AULA \\
\hline & $\begin{array}{l}\text { 2. Conhecendo as radiações e o } \\
\text { espectro eletromagnético. }\end{array}$ & $\begin{array}{l}\text { Discussão sobre os tipos radiações e a } \\
\text { diferença quanto a sua natureza. (15 min) } \\
\text { Sistematização e respostas às perguntas do } \\
\text { texto } 1 \text { e 2: "Conhecendo as Radiações" e } \\
\text { "Espectro Eletromagnético (Introdução)". } \\
\text { (30 min) }\end{array}$ & 1 AULA \\
\hline & $\begin{array}{l}\text { 3. Montagem do transmissor de } \\
\text { ondas eletromagnéticas. }\end{array}$ & \begin{tabular}{|l|} 
Atividade 3 - Demonstração do Transmissor \\
de Ondas Eletromagnéticas. (10 min) \\
Discussão sobre as ondas de rádio e as \\
microondas. (20 min) \\
Sistematização e respostas às perguntas do \\
texto "Espectro Eletromagnético (Parte I)". \\
(15 min) \\
\end{tabular} & 1 AULA \\
\hline & 4. Dispersão da luz. & \begin{tabular}{|l|} 
Atividade 4 - Dispersão da luz. (15 min) \\
$\begin{array}{l}\text { Discussão sobre a luz visível e os raios } \\
\text { infravermelhos. ( } 20 \text { min) }\end{array}$ \\
$\begin{array}{l}\text { Sistematização, leitura e respostas às } \\
\text { perguntas do texto "Espectro Eletromagnético } \\
\text { (Parte II)". (10 min) }\end{array}$ \\
\end{tabular} & 1 AULA \\
\hline & $\begin{array}{l}\text { 5. Analisando radiografias e e } \\
\text { analogia entre radiografia e papel } \\
\text { fotográfico. }\end{array}$ & \begin{tabular}{|l|} 
Atividade 5 - Analisando radiografias. (20 min) \\
Discussão sobre a descoberta dos raios X, sua \\
natureza na época desconhecida e suas \\
aplicações. ( 25 min) \\
Leitura e sistematização do texto "Espectro \\
Eletromagnético (Parte II)". (20 min) \\
\end{tabular} & 2 AULAS \\
\hline & & \begin{tabular}{|l|l|}
$\begin{array}{l}\text { Vídeo: "Telecurso 2000: Espectro } \\
\text { eletromagnético". (15 } \mathrm{min})\end{array}$ & \\
\end{tabular} & \\
\hline & 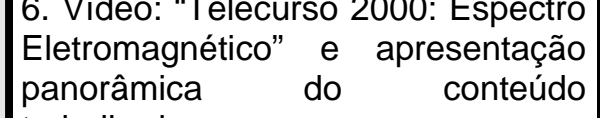 & $\begin{array}{l}\text { Sistematização e respostas às perguntas do } \\
\text { texto "Espectro Eletromagnético (Parte III)". } \\
\text { (20 min) }\end{array}$ & 2 AULAS \\
\hline & & $\begin{array}{|lll|}\begin{array}{l}\text { Apresentação panorâmica } \\
\text { trabalhado. }(10 \mathrm{~min})\end{array} & \text { do conteúdo } \\
\end{array}$ & \\
\hline & & Avaliação referente ao bloco 1. (45 min) & \\
\hline
\end{tabular}




\section{BLOCO 1 - RADIAÇÕES ELETROMAGNÉTICAS}

Iniciamos o nosso estudo da Física das Radiações pelo estudo e compreensão das radiações eletromagnéticas.

\section{Objetivos gerais:}

$\checkmark$ Estimular a curiosidade para o estudo de Física das Radiações.

$\checkmark$ Entender a natureza das radiações (ou ondas) eletromagnéticas e suas principais características.

$\checkmark$ Compreender o espectro eletromagnético e as diferentes radiações que o compõem.

\section{Conteúdo Físico}

$\checkmark$ Radiações eletromagnéticas: produção e propagação.

$\checkmark$ Espectro eletromagnético e suas radiações: ondas de rádio, microondas, raios infravermelhos, luz visível, raios ultravioleta, raios $X$ e raios gama.

\section{Leitura complementar}

As leituras indicadas servem para um conhecimento mais profundo e detalhado dos conceitos tratados neste bloco. Assim, caso seja possível, leia algumas dessas referências antes de iniciar as aulas.

$\checkmark$ ALVARENGA, Beatriz; MÁXIMO, Antônio. Física. $2^{\mathrm{a}}$ ed., $1^{\mathrm{a}}$ impressão, São Paulo: Editora Scipione, 2007.

$\checkmark$ GASPAR, Alberto. Eletromagnetismo e Física Moderna. $1^{\mathrm{a}}$ ed., $2^{\mathrm{a}}$ impressão, São Paulo: Editora Ática, 2001.

$\checkmark$ HEWITT, Paul. Física Conceitual. 9a ed. Porto Alegre: Bookman, 2002.

$\checkmark$ SERWAY, Raymound A.; JEWETT, John W. Princípios de Física: Óptica e Física Moderna. $3^{\mathrm{a}}$ ed. Rio de Janeiro: Thomson, 2005.

$\checkmark$ TIPLER, Paul A.; LLEWELLYN, Ralph A. Física Moderna. $3^{\mathrm{a}}$ ed. Rio de Janeiro: LTC, 2001. 


\section{Quadro Sintético}

\begin{tabular}{|c|c|c|c|}
\hline ATIVIDADES & MOMENTOS & COMENTÁRIOS & Tempo \\
\hline \multirow[b]{2}{*}{$\begin{array}{l}\text { 1. Analisando a } \\
\text { chama de uma vela. }\end{array}$} & $\begin{array}{l}\text { Propor e explicar o conteúdo do curso. } \\
\text { Atividade } \mathbf{1} \text { - Alunos respondem ao } \\
\text { questionário inicial. } \\
\text { Atividade } 2 \text { - Análise da chama da vela. }\end{array}$ & $\begin{array}{l}\text { A atividade motivacional e } \\
\text { introdutória aos assuntos } \\
\text { que serão abordados. }\end{array}$ & \multirow[b]{2}{*}{2 aulas } \\
\hline & $\begin{array}{l}\text { Discussão sobre a análise da chama da } \\
\text { vela. Sistematização e respostas às } \\
\text { perguntas dos textos. } \\
\text { Correção e discussão das questões dos } \\
\text { textos. }\end{array}$ & $\begin{array}{l}\text { Textos: "Conhecendo as } \\
\text { Radiações" e "Espectro } \\
\text { Eletromagnético". }\end{array}$ & \\
\hline $\begin{array}{l}\text { 2. Gerando ondas } \\
\text { eletromagnéticas. }\end{array}$ & $\begin{array}{l}\text { Atividade } 3 \text { - Transmissor de Ondas } \\
\text { Eletromagnéticas. } \\
\text { Demonstração investigativa sobre a } \\
\text { geração de ondas eletromagnéticas. } \\
\text { Discussão sobre a geração de ondas } \\
\text { eletromagnéticas. Sistematização e } \\
\text { respostas às perguntas do texto. }\end{array}$ & $\begin{array}{c}\text { Produzindo uma onda } \\
\text { eletromagnética com um } \\
\text { pedaço de fio metálico e } \\
\text { uma pilha. }\end{array}$ & 1 aula \\
\hline \multirow{2}{*}{$\begin{array}{l}\text { 3. Fazendo a } \\
\text { dispersão da luz. }\end{array}$} & Atividade 4 - Dispersão da luz. & $\begin{array}{l}\text { Fazendo a dispersão da luz } \\
\text { com um prisma ou um CD. }\end{array}$ & \multirow[b]{2}{*}{1 aula } \\
\hline & $\begin{array}{l}\text { Discussão sobre a geração de ondas } \\
\text { eletromagnéticas. Sistematização e } \\
\text { respostas às perguntas do texto. }\end{array}$ & $\begin{array}{c}\text { Texto: "Espectro } \\
\text { Eletromagnético (Parte II)". }\end{array}$ & \\
\hline \multirow[t]{2}{*}{ 4. Radiografias. } & Atividade 5 - Analisando radiografias. & $\begin{array}{l}\text { Atividade motivacional e } \\
\text { introdutória aos assuntos } \\
\text { que serão abordados. }\end{array}$ & \multirow{2}{*}{2 aulas } \\
\hline & $\begin{array}{l}\text { Discussão sobre a descoberta dos raios } \\
\text { X, sua natureza na época desconhecida } \\
\text { e suas aplicações. Sistematização e } \\
\text { respostas às perguntas do texto. }\end{array}$ & $\begin{array}{c}\text { Texto: "Espectro } \\
\text { Eletromagnético (Parte III)". }\end{array}$ & \\
\hline 5. Avaliação. & $\begin{array}{l}\text { Aplicação de uma avaliação sobre o } \\
\text { conteúdo trabalhado no bloco } 1 .\end{array}$ & & 1 aula \\
\hline
\end{tabular}




\section{Descrição aula-a-aula}

AULA 1

Tema: Chama de uma vela.

Objetivo: Sensibilizar e motivar os alunos para o estudo da Física das Radiações através da análise da chama de uma vela.

Conteúdo Físico: Concepções prévias sobre Física das Radiações e ondas eletromagnéticas.

\section{Recursos Instrucionais:}

- Questionário inicial;

- Roteiro da atividade 1;

- Roteiro da atividade 2;

- Velas;

- Lápis de cor.

Motivação: Curiosidade sobre as diferentes colorações presentes na chama de uma vela.

\section{Momentos:}

\begin{tabular}{|c|c|}
\hline \multirow[t]{2}{*}{ 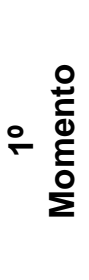 } & $\begin{array}{l}\text { Apresentação geral da proposta de curso para a sala. } \\
\text { Entrega do questionário individual: Questionário Inicial (atividade 1). } \\
\text { Tempo para os alunos responderem. O professor deve enfatizar que a proposta dessa } \\
\text { atividade é verificar o que os alunos sabem sobre essa área de conhecimento, instigar } \\
\text { sua curiosidade sem nenhuma finalidade avaliativa, pois os alunos costumam } \\
\text { apresentar uma preocupação enorme com a nota. }\end{array}$ \\
\hline & Tempo: $\pm 20 \mathrm{~min}$ \\
\hline
\end{tabular}

\begin{tabular}{|c|c|}
\hline \multirow{2}{*}{ 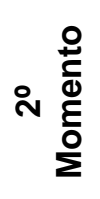 } & $\begin{array}{l}\text { Propor a atividade 2: enquanto entrega as velas e o roteiro da atividade, separe os } \\
\text { alunos em grupos de aproximadamente } 5 \text { alunos, de modo que eles discutam as } \\
\text { questões propostas no roteiro. }\end{array}$ \\
\hline & Tempo: $\pm 25 \min$ \\
\hline
\end{tabular}

Sugestão: Você pode pedir aos alunos uma pesquisa sobre a chama de uma vela, as diferentes colorações que ela apresenta e a temperatura em cada uma das regiões encontradas durante a atividade investigativa.

Dinâmica da Aula: após o professor explicar o curso, apresentando sucintamente o conteúdo que será abordado e seu caráter inovador no ensino de física da escola média, os alunos respondem a um questionário para que o professor possa compreender suas concepções prévias sobre o assunto. Depois, os alunos exploram e registram em uma folha de sulfite, a chama da vela que estão observando, com as respectivas regiões e colorações encontradas. Você pode começar a atividade perguntando aos alunos como é a chama de uma vela, seu formato, que colorações ela apresenta, por exemplo. Outras perguntas que podem ser feitas são as seguintes: Toda vela tem o mesmo tipo de chama? Qual região da chama é mais quente, isto é, qual tem a maior temperatura? Qual tem a menor temperatura? Em qual delas temos a maior energia? E a menor energia? Estas perguntas podem ajudar a dar o pontapé inicial nas discussões que os alunos farão em seus respectivos grupos. Lembrar a eles que o ponto de partida para a discussão é a percepção das diferentes cores que correspondem a diferentes temperaturas da chama e de outros detalhes que chamem a sua atenção é importante, pois servirão de ponto de partida para a sistematização que será feita na aula seguinte. 


\section{AULA 2}

Tema: Conhecendo as radiações.

Objetivo: Discutir o estudo do espectro eletromagnético e as radiações que o compõem.

Conteúdo Físico: Espectro eletromagnético.

\section{Recursos Instrucionais:}

- Discussão entre professor e aluno baseado nos textos: "Conhecendo as Radiações" e "Espectro Eletromagnético (Introdução)".

- Aula expositiva.

Motivação: Curiosidade em compreender as respostas das questões levantadas na aula anterior.

\section{Momentos:}

○ Retomada das discussões da aula anterior para sistematização do conceito. Os alunos 苞 retomam os grupos da aula anterior para que possa ser feita a leitura do textos: ㄱ 리 "Conhecendo as Radiações" e "Espectro Eletromagnético (Introdução)". Respondendo $\stackrel{0}{\Sigma}$ as questões propostas nos textos.

\section{Tempo: $\pm 15 \mathrm{~min}$}

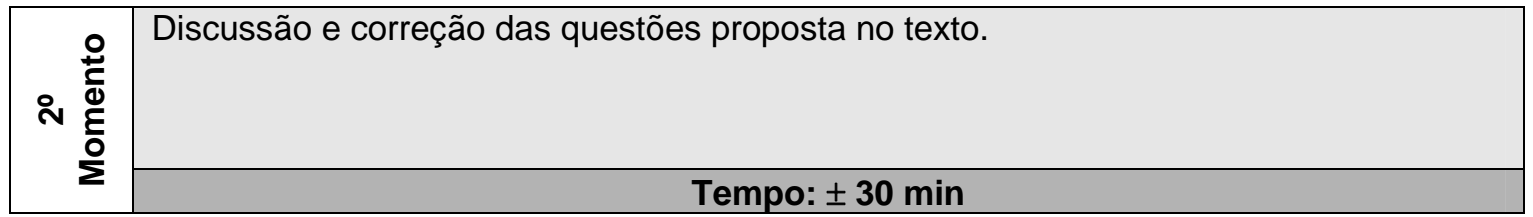

Sugestão: O professor pode explorar os diferentes intervalos das radiações eletromagnéticas presentes no espectro eletromagnético. Ressaltar que o intervalo da luz visível é o menor de todos. Lembrá-los que cada radiação eletromagnética tem características como freqüência e comprimento de onda que permitem diferenciá-las dentro do espectro.

Dinâmica da Aula: Inicie a aula retomando a discussão da aula anterior, em seguida peça aos alunos para lerem o texto e responderem as questões propostas (isso pode ser feito em grupo). Corrija as questões fazendo uma sistematização final. 


\section{AULA 3}

Tema: Gerando uma onda eletromagnética.

Objetivo: Sensibilizar e motivar os alunos para o mecanismo de geração de uma onda eletromagnética.

Conteúdo Físico: Ondas eletromagnéticas.

\section{Recursos Instrucionais:}

- Roteiro da atividade 3;

- Pedaço de fio metálico;

- Pilha grande;

- Rádio AM;

- Texto: "Espectro Eletromagnético (Parte I)".

Motivação: Curiosidade sobre geração de ondas eletromagnéticas.

\section{Momentos:}

\begin{tabular}{|c|c|}
\hline \multirow[t]{2}{*}{ 일 } & $\begin{array}{l}\text { Demonstrar a atividade 3: "Transmissor de Ondas Eletromagnéticas". O professor faz a } \\
\text { demonstração da produção de uma onda eletromagnética com o auxílio de uma pilha } \\
\text { grande e um pedaço de fio metálico. Com o rádio AM tenta mostrar que é possível } \\
\text { detectar essa onda produzida. }\end{array}$ \\
\hline & Tempo: $\pm 10 \mathrm{~min}$ \\
\hline
\end{tabular}

\begin{tabular}{|c|c|}
\hline \multirow{2}{*}{ 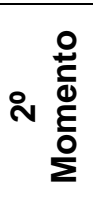 } & $\begin{array}{l}\text { Sistematização da atividade e discussão sobre as ondas de rádio e as microondas com } \\
\text { base no texto: "Espectro Eletromagnético. (Parte I)". }\end{array}$ \\
\hline & Tempo: $\pm 20 \mathrm{~min}$ \\
\hline
\end{tabular}

\begin{tabular}{|c|c|}
\hline \multirow{2}{*}{ 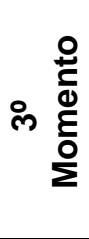 } & $\begin{array}{l}\text { Discussão sobre as questões: Instigue os alunos a falarem sobre as questões, desta } \\
\text { forma a discussão será mais interativa. Mas procure encaminhá-la para o processo de } \\
\text { produção das ondas eletromagnéticas e a forma de detectá-las. }\end{array}$ \\
\hline & Tempo: $\pm 15 \mathrm{~min}$ \\
\hline
\end{tabular}

Sugestão: O professor deve realizar a montagem antes da aula para verificar se é possível através do rádio AM disponibilizado, detectar as ondas eletromagnéticas geradas ao realizar o curto-circuito momentâneo entre os pólos da pilha. Este curto-circuito deve ser breve, isto é, deve-se apenas tocar e soltar o fio para causar o curto, não mantendo o fio conectado a pilha durante muito tempo, pois se corre o risco de provocar seu aquecimento e descarga. Você pode pedir também aos alunos uma pesquisa de campo sobre o funcionamento de uma antena de um aparelho receptor de rádio, como o rádio de Galena, que foi um dos pioneiros nessa tarefa.

Dinâmica da Aula: iniciar a discussão relembrando o que são as ondas eletromagnéticas e como elas são geradas. Em seguida, demonstrar através do arranjo pilha, fio e rádio $A M, a$ produção e detecção das ondas eletromagnéticas através de um curto-circuito entre o fio e a pilha. Enfatizar que as ondas geradas são transmitidas pela antena, propagando-se pelo espaço, transportando energia, sendo detectadas com o auxílio de uma outra antena e circuitos adequados como o de um rádio AM. Falar da posição das ondas de rádio no espectro, e depois, das microondas que fazem uma fronteira com as ondas de rádio. Comentar sobre o aparelho de microondas que faz uso deste tipo de radiação para aquecer os alimentos, pois as microondas que ele gera conseguem interagir com as moléculas de água dos alimentos, aumentando sua agitação, e, portanto, causando o seu aquecimento. Finalmente, peça para que eles respondam às questões propostas no texto. 


\section{AULA 4}

Tema: Dispersão da luz visível.

Objetivo: Sensibilizar e motivar os alunos para o estudo da luz visível, usando para isso o fenômeno de dispersão da luz.

Conteúdo Físico: Luz visível e dispersão da luz.

\section{Recursos Instrucionais:}

- Roteiro da atividade 4;

- Lâmpada incandescente ou fluorescente;

- Prisma ou CD;

- Lápis de cor.

Motivação: Despertar a curiosidade sobre a imagem obtida após a luz atravessar um prisma ou refletir em $C D$.

\section{Momentos:}

\begin{tabular}{|c|c|}
\hline \multirow{2}{*}{ ㄱ } & $\begin{array}{l}\text { Realização da atividade } 4 \text { : "Dispersão da Luz". Os alunos se reúnem em pequenos } \\
\text { grupos de } 5 \text { alunos e fazem com os materiais fornecidos a dispersão da luz, } \\
\text { registrando os resultados obtidos. }\end{array}$ \\
\hline & Tempo: \pm 15 min \\
\hline
\end{tabular}

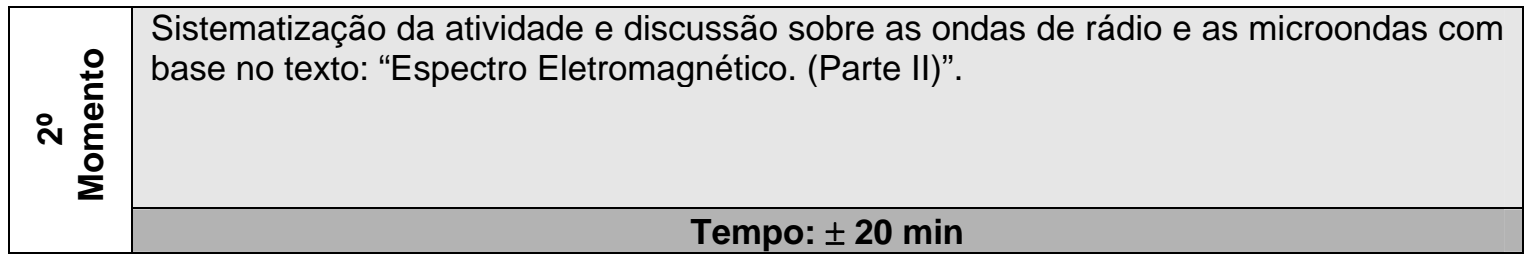

\begin{tabular}{|c|c|}
\hline \multirow{2}{*}{ 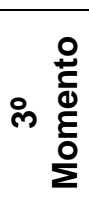 } & $\begin{array}{l}\text { Discussão sobre as questões: Instigue os alunos a falarem sobre as questões, desta } \\
\text { forma a discussão será mais interativa. Mas procure encaminhá-la para o processo de } \\
\text { produção das ondas eletromagnéticas e a forma de detectá-las. }\end{array}$ \\
\hline & Tempo: $\pm 10 \mathrm{~min}$ \\
\hline
\end{tabular}

Sugestão: O professor deve realizar a dispersão da luz previamente de forma a identificar o espectro de cores que os alunos irão obter. Isso pode facilitar seu trabalho, pois assim saberá que padrão será obtido. O uso do prisma apresenta bons resultados em uma sala escurecida, porém na sua ausência, pode-se usar um CD que também apresenta resultados satisfatórios. Reforçar o fenômeno da dispersão da luz, a difração que ocorre no CD e apontar para as diferentes freqüências que temos em cada uma das cores obtidas no espectro visível.

Dinâmica da Aula: iniciar a discussão sobre o que ocorre quando a luz atravessa um prisma ou difrata em um $C D$. O que se observa? Relembrar os fenômenos de refração e difração da luz e reforçar que a luz branca é formada por um conjunto de cores que recebe o nome de espectro da luz visível. Assim, estabelecer que cada cor observada representa uma onda eletromagnética com freqüência, comprimento de onda e energia bem definidos. Discutir sobre por que vemos estas radiações e outras não, como as ondas de rádio, TV, microondas e infravermelho. Comentar sobre o controle remoto que utiliza os raios infravermelhos para se comunicar com a TV, entre outros equipamentos. Lembrar que todos os corpos quentes emitem infravermelho. Enfatizar que nossos olhos são os detectores naturais que temos para observar as radiações da luz visível, enquanto que para outras radiações, como os raios infravermelhos, precisamos de dispositivos especiais. Finalmente, peça para que eles respondam às questões propostas no texto. 


\section{AULA 5}

Tema: Descoberta dos raios $\mathrm{X}$.

Objetivo: Sensibilizar e motivar os alunos para o estudo da física de partículas e dos raios $\mathrm{X}$, através da análise de um efeito dos raios $X$ : a radiografia.

Conteúdo Físico: Concepções prévias sobre física de partículas e raios $\mathrm{X}$.

\section{Recursos Instrucionais:}

- Roteiro da atividade 5;

- Radiografias diversas;

- Texto: Espectro Eletromagnético (Parte II);

- Texto Suplementar: "Vendo através da pele: a descoberta dos raios X".

Motivação: Curiosidade sobre as radiografias e as chapas radiográficas.

\section{Momentos:}
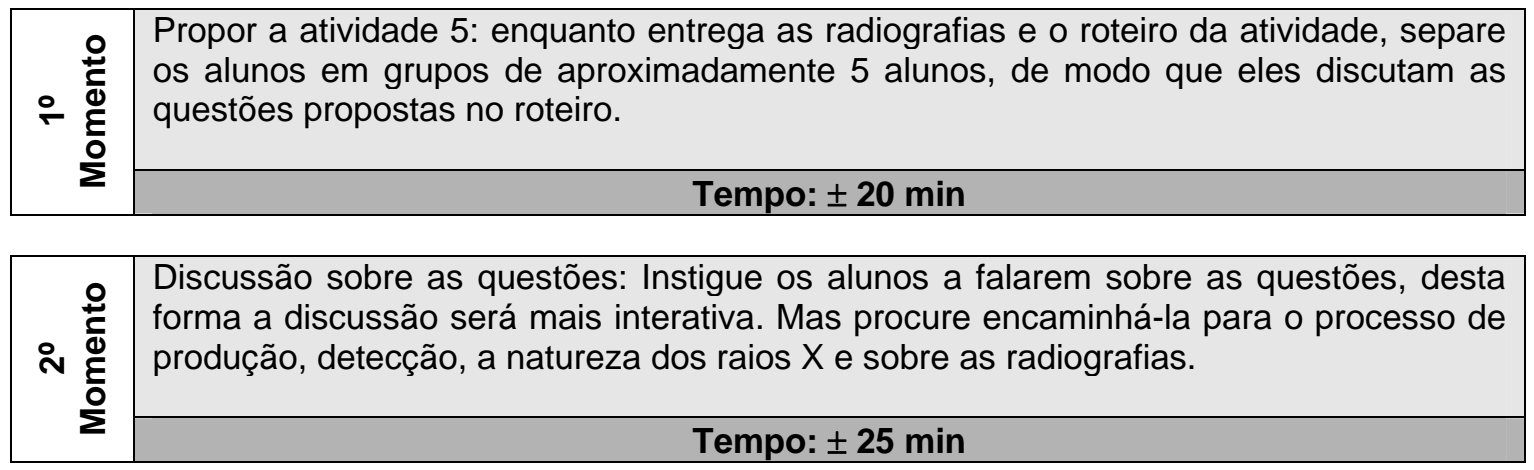

Sugestão: Caso as aulas não sejam no mesmo dia e o professor perceba a dificuldade, por parte dos alunos em formarem os grupos, pode optar por realizar a atividade com o papel fotográfico. Aproveitando que os grupos já estão formados evita-se um gasto de tempo extra para organização dos grupos novamente na $2^{\mathrm{a}}$ aula. Nesse caso as questões devem ser trabalhadas pelos grupos na aula seguinte. Você pode pedir aos alunos uma pesquisa de campo com médicos, centros de radiologia e profissionais da área.

Dinâmica da Aula: Os alunos iniciam explorando as imagens nas diversas radiografias. Você pode começar a atividade perguntando quais alunos já tiraram radiografias e aí pedir para que contem sobre o processo. Sugestão de possíveis perguntas para esta aula: onde a radiografia é tirada? Qual a preparação para o exame? Fica alguém na sala? Por que o funcionário "some"? Para onde ele vai? Por que em alguns exames colocamos um colete de chumbo? Quando você sabe que os raios X passaram por você? Apesar do barulhinho que se ouve, você vê os raios $X$ ? Como saber se a radiografia foi tirada? Onde fica a chapa da radiografia durante o exame? Como alguns órgãos e os ossos aparecem na chapa? Estimule-os a analisarem pelo menos 3 radiografias e a "brincarem" de fazer diagnóstico. Peça para que observem onde a radiografia é mais clara e a que partes do corpo correspondem. Preferencialmente os alunos devem responder por escrito às questões, mas essa atividade pode ser feita apenas com a discussão entre os grupos e depois com o professor. Caso surjam questões sobre o acidente de Goiânia, ou sobre urânio e césio, peça para que aguardem "as cenas dos próximos capítulos". Lembre-se de comentar com os alunos sobre a utilização do chumbo na proteção contra a ação dos raios X. Faça uma breve sistematização dos conceitos discutidos, focando a parte histórica e a parte física dos raios $\mathrm{X}$. 


\section{AULA 6}

Tema: Descoberta dos raios $\mathrm{X}$.

Objetivo: Discutir sobre a descoberta, a produção e a utilização atual dos raios $X$ e da radioatividade.

\section{Conteúdo Físico: Raios X.}

\section{Recursos Instrucionais:}

- Texto: Espectro Eletromagnético (Parte III);

- Texto Suplementar: "Vendo através da pele: a descoberta dos raios X".

- Discussão entre professor e alunos baseada no texto "Vendo através da pele: a descoberta dos raios X (texto suplementar)";

- Aula expositiva;

- Algumas radiografias.

Motivação: Curiosidade em compreender as respostas das questões levantadas na aula anterior.

\section{Momentos:}

\begin{tabular}{|c|c|}
\hline \multirow[t]{2}{*}{ 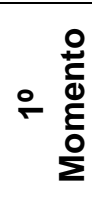 } & $\begin{array}{l}\text { Retomada das discussões da aula anterior para sistematização do conceito. } \\
\text { Os alunos retomam os grupos da aula anterior para que possa ser feita a leitura do } \\
\text { texto; "Vendo através da pele: a descoberta dos raios X". Respondendo as questões } \\
\text { propostas no texto. }\end{array}$ \\
\hline & Tempo: $\pm 25 \mathrm{~min}$ \\
\hline
\end{tabular}

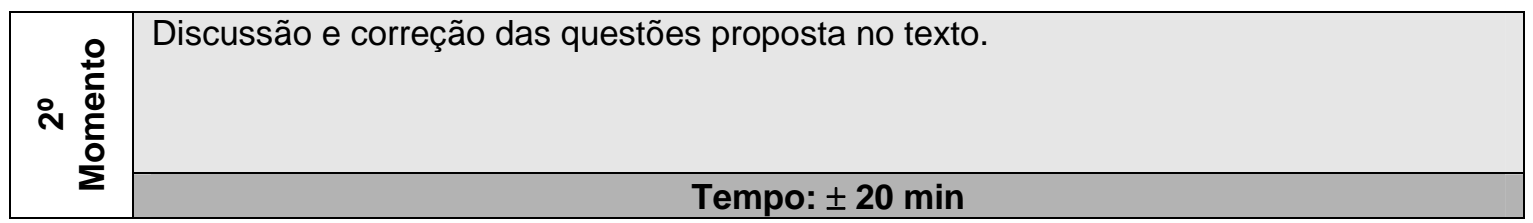

Sugestões: $\mathrm{O}$ professor pode explorar os efeitos biológicos dos raios X. Aproveitando a atenção dos alunos, explique como eram complicados os exames antigamente.

Dinâmica da Aula: Inicie a aula retomando a discussão da aula anterior, em seguida peça aos alunos para lerem o texto e responderem as questões propostas (isso pode ser feito em grupo). Corrija as questões fazendo uma sistematização final. 


\section{AULA 7}

Tema: Revisando o espectro eletromagnético.

Objetivo: Destacar os assuntos estudados até o momento.

Conteúdo Físico: Ondas eletromagnéticas e o espectro eletromagnético.

\section{Recursos Instrucionais:}

- Vídeo: Telecurso 2000: Espectro Eletromagnético;

- Aula expositiva.

Motivação: Sistematização e organização dos assuntos tratados até o momento.

Momentos:
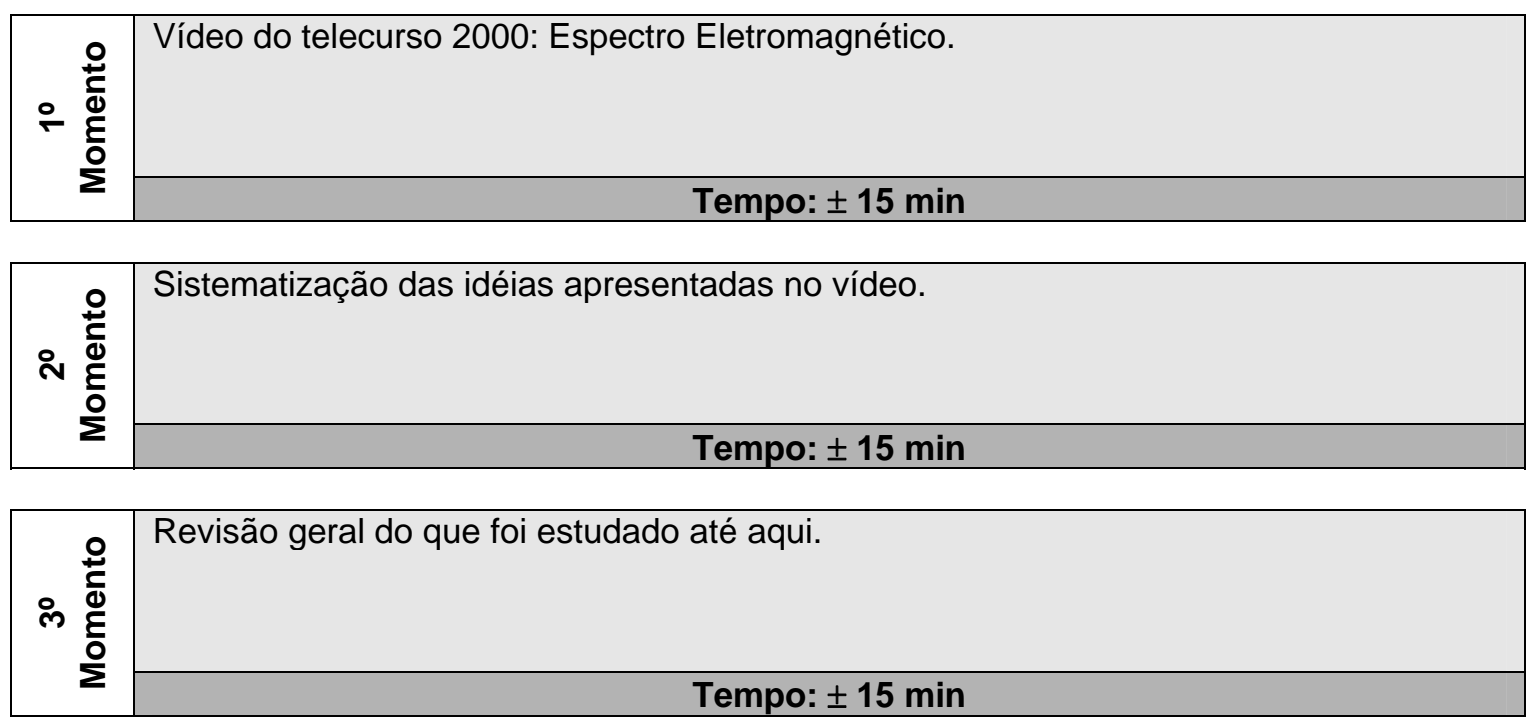

Dinâmica da Aula: Inicia-se a aula com o vídeo do telecurso 2000 sobre o espectro eletromagnético. Em seguida faça uma sistematização das idéias apresentadas no vídeo. Assim é possível fazer uma discussão final, revisando todos os conceitos estudados até o momento.

Observação: O professor deve procurar destacar os pontos importantes que deseja discutir nessa aula utilizando uma apresentação em PowerPoint ou mesmo pontuando na lousa, para não correr o risco de dispersar e perder o foco principal. Pode também, utilizar essa aula para retomar questões que não estejam bem resolvidas ou apresentar novos questionamentos sem esquecer que a idéia principal no momento é uma preparação para avaliação dos assuntos discutidos nesse bloco. 


\section{AULA 8}

Tema: Radiações eletromagnéticas.

Objetivo: Verificação da aprendizagem.

Recursos Instrucionais:

- Avaliação escrita.

Momentos:

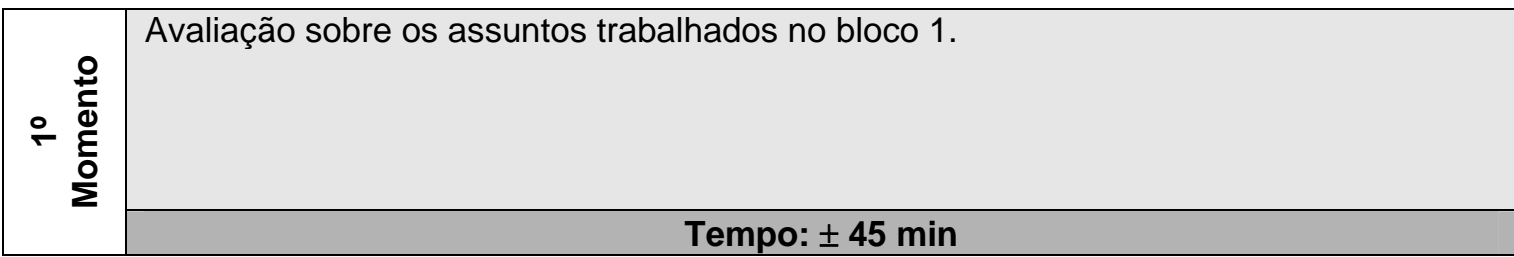

Observação: Caso o professor tenha a disponibilidade de duas aulas em seqüência pode iniciar a avaliação um pouco antes de terminar $9^{a}$ aula disponibilizando mais tempo de resolução para os alunos.

Dinâmica da Aula: entrega das avaliações individuais sobre o bloco 1. 


\section{Apresentação do Curso}

Você acorda com o despertador. A luz do Sol entra pela janela enquanto você pula da cama, toma um banho, se veste e desce para tomar café. Na cozinha, coloca duas fatias de pão na torradeira e esquenta uma xícara de café no forno de microondas. Enquanto espera, dá uma olhada nos bilhetes presos à geladeira por pequenos ímãs.

A narrativa acima expressa muitas vezes o cotidiano de pessoas nos mais diversos lugares do mundo, mas você notou quantas coisas mencionadas nesta narrativa têm a ver com radiação e alguma forma de sua manifestação? Em particular, os raios solares que entraram pela janela e as ondas que existem no interior de um forno de microondas são exemplos de ondas eletromagnéticas, ou melhor, de radiações eletromagnéticas. Além disso, percebemos também que existe a presença da eletricidade e do magnetismo entre as situações citadas acima, promovendo o aparecimento de alguma forma de radiação.

As questões que surgem quando pensamos em radiação são muitas, mas podemos destacar as seguintes:

- A radiação pode prejudicar a nossa saúde?

- Quais são os tipos de radiações, como são geradas e quais as suas diferenças?

- Estamos preparados para acidentes em que tenhamos radiação envolvida?

- Qual a relação entre a radioatividade e radiação?

- Um aparelho de microondas pode nos prejudicar?

- Por que as bombas atômicas jogadas sobre as cidades de Hiroshima e Nagasaki mataram tantas pessoas, se elas não eram não tão "grandes"?

- O celular tem radioatividade? E as pilhas e baterias?

Para explicarmos corretamente a todas essas questões, precisamos nos aprofundar no estudo das radiações, ou melhor, entrarmos no campo da Física das Radiações e com o seu auxílio buscarmos elementos que nos permitam reconhecer os diferentes tipos de radiação, suas principais características, a maneira de sua interação com a matéria e os benefícios e prejuízos que ela pode trazer para a nossa vida cotidiana.

Este curso de Física das Radiações tem exatamente esse intuito, o de trazer elementos para que o estudante do ensino médio possa compreender de maneira clara os conceitos básicos sobre Radiação, permitindo a ele uma maior interação com o mundo e com as tecnologias que se utilizam desta forma de energia.

Para iniciá-lo no estudo deste campo fascinante da Física, começaremos o curso respondendo a um questionário inicial. Sua intenção é de formalizar o que você conhece sobre o tema, de modo a auxiliá-lo em seu estudo e que servirá ao término do curso como uma referência quanto ao que foi assimilado por você, além de apontar melhorias e correções quanto a sua execução. 


\section{Conhecendo as Radiações}

Voltemos a aquela narrativa inicial: "Você acorda com o despertador. A luz do Sol entra pela janela enquanto você pula da cama, toma um banho, se veste e desce para tomar café. Na cozinha, coloca duas fatias de pão na torradeira e esquenta uma xícara de café no forno de microondas. Enquanto espera, dá uma olhada nos bilhetes presos à geladeira por pequenos ímãs". Estamos o tempo inteiro sendo bombardeados por radiações de todos os lados, algumas delas perceptíveis aos nossos sentidos, como por exemplo, a luz, enquanto outras praticamente passam despercebidas. O Sol que entra pela janela representa uma forma de radiação que comumente chamamos de radiação solar. Já ao colocarmos as fatias de pão na torradeira estamos utilizando a radiação infravermelha para prepará-las ao nosso gosto, ou seja, deixá-las torradinhas. No aparelho de microondas temos a geração das microondas que permitem aquecer a substância no interior do aparelho, deixando, por exemplo, o café, do jeitinho que queremos, isto é, bem quentinho.

O que estas situações têm em comum? Em todas elas percebemos o uso de algum tipo de radiação. Mas será que as radiações são todas iguais? O que elas têm de diferente entre si? Primeiramente, precisamos conhecer o que é essa "coisa" chamada "radiação", para depois entendermos os mecanismos de sua geração, classificando os diferentes tipos de radiação e a maneira com a qual elas interagem com a matéria, além das muitas aplicações que são feitas a partir delas.

Procurando no dicionário Aurélio (Novo Dicionário Eletrônico Aurélio versão 5.0), encontramos as seguintes definições para radiação:

$\checkmark$ Ato ou efeito de radiar.

$\checkmark$ Qualquer dos processos físicos de emissão e propagação de energia, seja por intermédio de fenômenos ondulatórios, seja por meio de partículas dotadas de energia cinética.

$\checkmark$ Energia que se propaga de um ponto a outro no espaço ou num meio material.

Assim, podemos afirmar que radiação é a propagação de energia sob várias formas, e que pode ser dividida geralmente em dois grupos:

- Radiação corpuscular (partículas) e;

- Radiação eletromagnética.

A radiação corpuscular é constituída de partículas elementares ou núcleos atômicos, tais como: elétrons, prótons, nêutrons, partículas alfa, dêuterons, entre outros, enquanto a radiação eletromagnética é constituída de ondas eletromagnéticas. Cada uma dessas radiações é caracterizada por sua energia, sua geração e forma de interação com a matéria. A radiação corpuscular será melhor compreendida quando fizermos a discussão sobre a Radioatividade e as reações nucleares, enquanto que a radiação eletromagnética será melhor compreendida com o estudo do espectro eletromagnético. 
Por uma opção de didática, faremos inicialmente o estudo da radiação eletromagnética e do espectro eletromagnético, de maneira a diferenciarmos os tipos de ondas eletromagnéticas quanto ao seu comprimento de onda ${ }^{1}$, freqüência ${ }^{2}$ e energia.

\section{Radiação Eletromagnética}

Devemos lembrar que as ondas eletromagnéticas têm origem no movimento de uma carga elétrica, que quando acelerada ou desacelerada, provoca variações em seu campo elétrico que, conseqüentemente, provoca variações em seu campo magnético e assim sucessivamente, levando a informação desse movimento aos pontos do espaço.

Toda onda eletromagnética transporta energia durante sua propagação e essa propagação é feita na velocidade da luz c $\left(300.000 .000 \mathrm{~m} / \mathrm{s}\right.$ ou $\left.3.10^{8} \mathrm{~m} / \mathrm{s}\right)$, característica mostrada por James Clerk Maxwell (1831-1879). A figura ao lado apresenta uma onda eletromagnética.

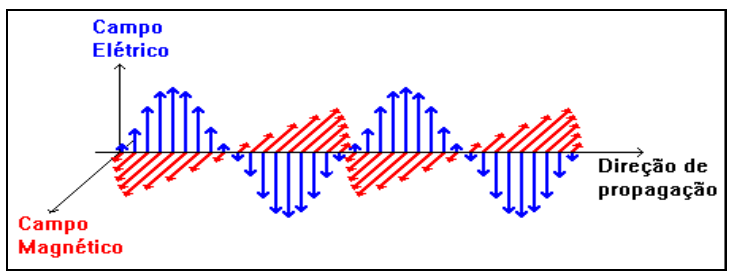

onda eletromagnética

Como toda onda, a onda eletromagnética tem a freqüência como uma característica importante, por que é através dela que as ondas eletromagnéticas são classificadas. A unidade de medida da freqüência é o Hertz $(\mathrm{Hz})$, em homenagem a Heinrich Rudolph Hertz (18571894), devido à descoberta das ondas de rádio. Para cada faixa de freqüência, usamos um termo diferente para descrevê-la. Por exemplo, a freqüência que vai de $4,3.10^{14} \mathrm{~Hz}$ até $7,5.10^{14}$ $\mathrm{Hz}$ é o que chamamos de luz visível, enquanto que as ondas de rádio estão na faixa de $10^{2} \mathrm{~Hz}$ até $10^{8} \mathrm{~Hz}$.

A freqüência é a medida das oscilações que a carga elétrica executa por unidade de tempo, isto é, se a freqüência de uma onda eletromagnética é de $10^{5} \mathrm{~Hz}$, ela oscila (agita) 100.000 vezes a cada segundo. Assim, para ser mais claro, se você tiver um pente eletrizado e quiser que ele produza a luz amarela cuja freqüência é de $5,2 \cdot 10^{14} \mathrm{~Hz}$, você terá que agitá-lo 520 trilhões de vezes por segundo. O que acha disso? Você consegue? Tente!

\section{A Energia das Ondas Eletromagnéticas}

Conforme relatado anteriormente, uma onda eletromagnética pode então ser produzida usando apenas um pente. Como ondas eletromagnéticas são geradas toda vez que um objeto eletrizado é acelerado ou desacelerado, imagine-se penteando o cabelo em um dia seco de inverno, quando é mais fácil o pente acumular cargas devido o atrito. Toda vez que você move o pente para um lado e para outro, o pente emite uma onda eletromagnética, afinal temos as cargas presentes nele sofrendo uma aceleração.

\footnotetext{
${ }^{1}$ Comprimento de onda: medida da distância entre duas cristas ou vales consecutivos em uma onda.

${ }^{2}$ Freqüência: corresponde a quantidade de ondas completas que são geradas por segundo.
} 
Se você se penteia devagar, passando o pente no cabelo uma vez por segundo, cria uma onda eletromagnética, mas não coloca muita energia nesta onda. Você produz uma onda de baixa energia e baixa freqüência, com comprimento de onda da ordem de $300.000 \mathrm{~km}$, pois a velocidade da luz é de $300.000 \mathrm{~km}$ por segundo. Se, por outro lado, você pudesse fazer o pente se mover mais rapidamente, digamos 300.000 vezes por segundo, você produziria uma onda de freqüência e energia muito maiores, com um comprimento de onda de $1 \mathrm{~km}$. Assim, usando mais energia para acelerar as cargas elétricas, você coloca mais energia na onda eletromagnética.

Certamente depois das ondas de rádio descobertas por Hertz em 1887, podemos considerar a luz visível como a outra integrante da família das ondas eletromagnéticas, mais conhecida pelo homem e que permite apoiar o raciocínio feito no parágrafo anterior. Por exemplo, um pedaço de carvão em brasa é vermelho-escuro, porque corresponde a uma cor que possui uma energia relativamente pequena. A chama amarela de uma vela tem um pouco mais de energia, enquanto que a chama branco-azulada de um maçarico, uma energia ainda maior. A cada cor corresponde uma freqüência e a cada freqüência uma energia diferente. Assim, quanto maior a freqüência da onda eletromagnética, maior será a sua energia.

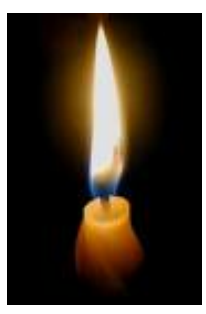

vela

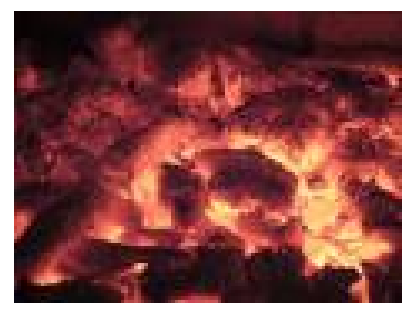

carvão

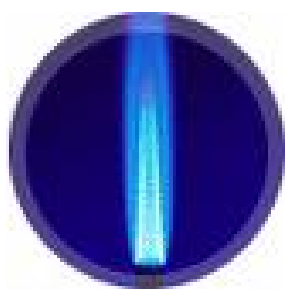

maçarico

O vermelho, com um comprimento de onda da ordem de $700 \mathrm{~nm}^{3}\left(4,3.10^{14} \mathrm{~Hz}\right)$, é a cor de maior comprimento de onda e menor energia do espectro da luz visível. O violeta, por outro lado, com comprimento de onda $400 \mathrm{~nm}\left(7,5.10^{14} \mathrm{~Hz}\right)$, é a cor de menor comprimento de onda e maior energia da luz visível. Todas as outras cores pertencentes ao espectro da luz visível têm energias entre as do vermelho e do violeta. Na figura abaixo temos o espectro eletromagnético com destaque para a parte do visível ao qual conseguimos enxergar.

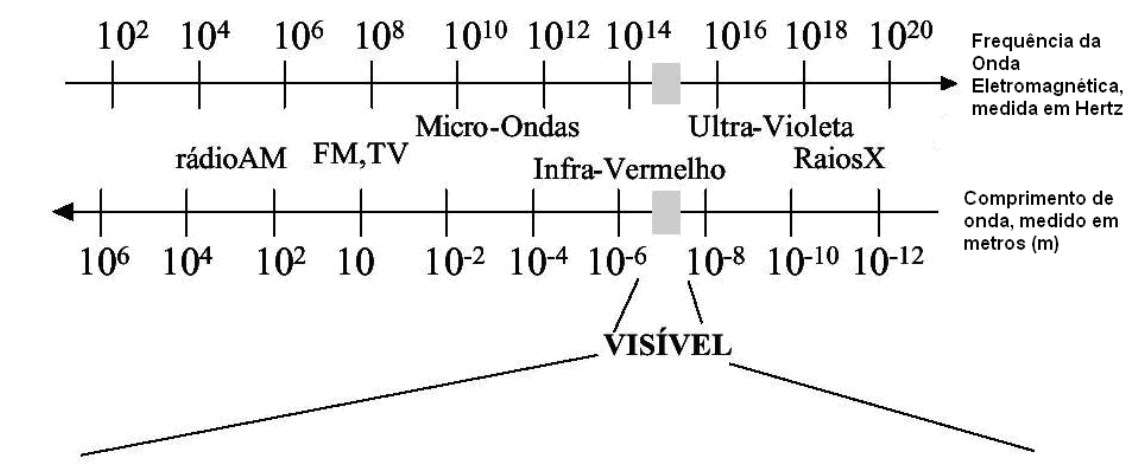

vermelho $\left(4.3 \times 10^{14} \mathrm{~Hz}\right)$, laranja, amarelo,..., verde, azul, violeta $\left(7.5 \times 10^{14} \mathrm{~Hz}\right)$

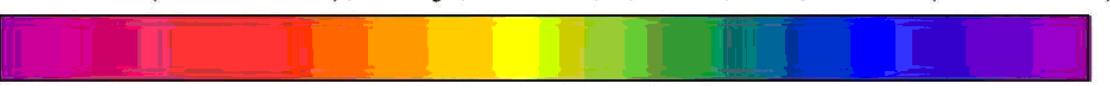

Espectro eletromagnético com destaque para a parte da luz visível

\footnotetext{
${ }^{3} 1$ nanômetro $(1 \mathrm{~nm})=0,000000001 \mathrm{~m}=10^{-9} \mathrm{~m}$
} 
Abaixo do vermelho temos, por exemplo, o infravermelho (ou radiação infravermelha) que é uma radiação não visível, enquanto que acima do violeta temos, por exemplo, o ultravioleta (ou radiação ultravioleta), que também não é visível aos nossos olhos.

Assim, o comprimento da onda, a sua freqüência e a sua energia, são grandezas que estão intimamente relacionadas. Na tabela abaixo podemos organizar essas idéias da seguinte forma:

\begin{tabular}{|c|c|c|}
\hline Comprimento da onda & Freqüência & Energia \\
\hline menor & maior & Maior \\
\hline maior & menor & Menor \\
\hline
\end{tabular}

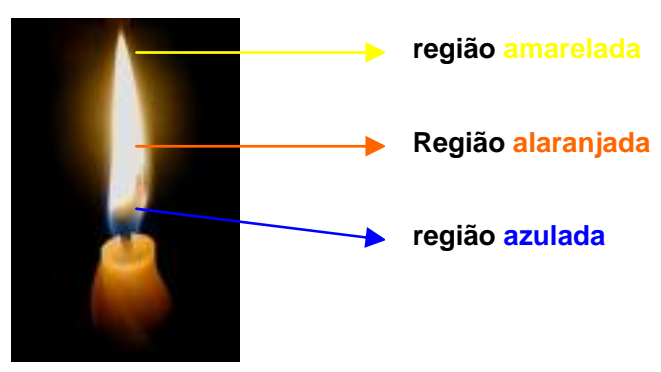

Vamos olhar novamente a chama de uma vela. A sua chama não é homogênea, apresentando regiões com cores diferentes como você deve ter percebido na atividade da análise da chama da vela.

Em cada região, temos uma temperatura diferente, e portanto, uma energia diferente. Podemos perceber que temos três regiões distintas: uma azulada (situada na parte inferior da chama, junto ao pavio), uma alaranjada (região situada entre o pavio e o topo da chama) e uma amarelada (parte do topo da chama). Destas três regiões, a mais quente é a azulada. O que podemos concluir diante disso, então? Provavelmente você concluiu que pela tabela acima, a parte azulada por ter a maior temperatura, tem a maior energia, logo tem maior freqüência com o menor comprimento de onda das três regiões. Já a região amarelada, tem a menor temperatura, a menor energia e freqüência, e conseqüentemente, o maior comprimento de onda.

\section{Questões}

1-) Como as ondas eletromagnéticas são produzidas?

2-) Qual a característica de uma onda eletromagnética que permite diferenciar uma da outra?

3-) Ao olharmos para uma vela, percebemos diferentes regiões em sua chama. Em qual dessas regiões temos maior energia? Onde temos a menor energia? Por quê?

4-) Ao olharmos para uma boca do fogão acesa, qual a cor da sua chama? O que podemos falar quanto a sua temperatura, energia, freqüência e comprimento de onda?

5-) O que ocorre com a chama de uma boca de fogão quando a válvula que regula o gás do botijão está vencida?

6-) Imagine uma estrela. Que cor deveria apresentar esta estrela para que ela fosse a mais quente e visível? 


\section{Espectro Eletromagnético (Introdução)}

Quando acendemos uma vela ou quando ligamos uma lâmpada incandescente ou mesmo quando olhamos para os raios do Sol, temos em comum nestes três exemplos a presença da luz. Desde a sua identificação por Maxwell como sendo uma onda eletromagnética, muitas outras ondas eletromagnéticas foram descobertas com comprimentos de ondas que vão desde o tamanho do raio da Terra (aproximadamente $6.370 \mathrm{~km}$ ) até o tamanho do núcleo atômico (aproximadamente $10^{-15} \mathrm{~m}$ ). Podemos dar como exemplos de ondas eletromagnéticas as ondas de rádio, as microondas, os raios infravermelhos, os raios ultravioleta, os raios $X$, os raios gama e os raios cósmicos. O conjunto destas ondas é chamado de espectro eletromagnético.

O espectro eletromagnético é composto então por ondas que se propagam no vácuo com a velocidade da luz $\left(\mathbf{c}=\mathbf{3 . 1 0 ^ { 8 }} \mathrm{m} / \mathrm{s}\right.$ ), sem a necessidade de um meio material. Na figura abaixo temos o espectro eletromagnético com as muitas freqüências e comprimentos de onda que a compõem, e que podem ser relacionados pela expressão $\mathbf{c}=\lambda$. $\mathbf{f}$, onde $\lambda$ representa 0 comprimento de onda, em metros $(\mathrm{m})$, e $\mathbf{f}$ a freqüência da onda eletromagnética, medida em Hertz $(\mathrm{Hz})$.

Devemos perceber que quando dizemos que temos uma onda eletromagnética do tipo infravermelha, ou simplesmente, radiação infravermelha, na verdade temos um conjunto de ondas dentro de um intervalo de freqüências (ou comprimentos de onda) que receberam essa denominação. Na figura abaixo, percebemos que o intervalo de freqüência da luz visível corresponde a uma faixa muito pequena, sendo a menor de todas.

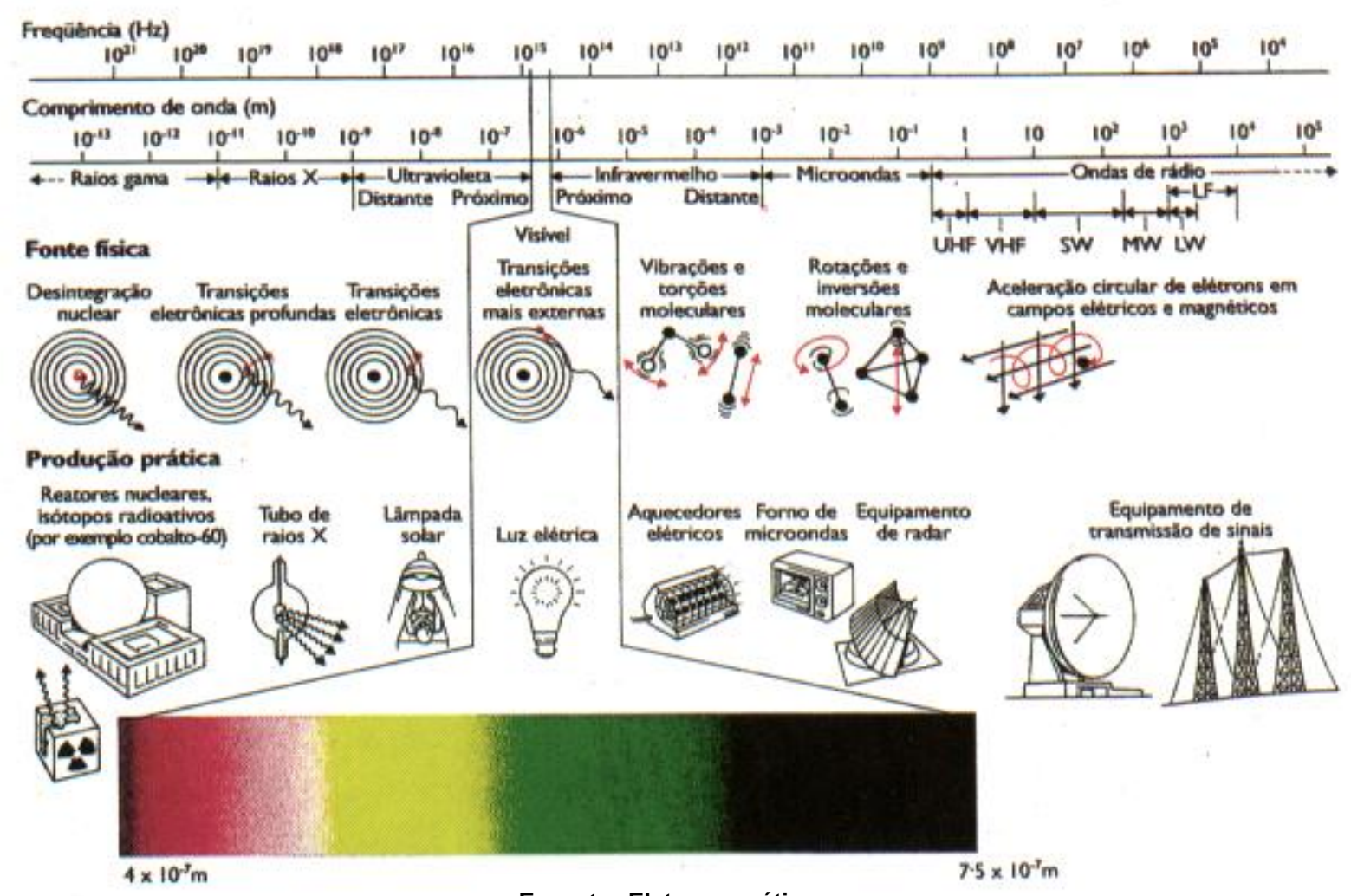

Espectro Eletromagnético 
Como ondas eletromagnéticas possuem comprimentos de onda com valores desde muito pequenos a muito grandes, podemos representar esses comprimentos através de unidades de medida adequadas. A tabela a seguir apresenta algumas unidades muito usadas para o comprimento de onda de algumas radiações eletromagnéticas:

\begin{tabular}{|c|c|c|}
\hline Tipo de Onda Eletromagnética & Comprimento de Onda & Observação \\
\hline Rádio, TV, Radar & de $3 \mathrm{~km} \mathrm{a} 1 \mathrm{~cm}$ & $\begin{array}{c}1 \mathrm{~km}=1.000 \mathrm{~m} \mathrm{=} 10^{3} \mathrm{~m} \\
1 \mathrm{~m}=100 \mathrm{~cm}=10^{2} \mathrm{~m}\end{array}$ \\
\hline Raios Infravermelhos & de $0,01 \mathrm{~cm} \mathrm{a} 8.000 \AA$ & $\begin{array}{c}\AA=\text { angstrom } \\
1 \AA=10^{-8} \mathrm{~cm}=10^{-10} \mathrm{~m}\end{array}$ \\
\hline Luz Visível & de $7.500 \AA$ a $3.900 \AA$ & - \\
\hline Raios Ultravioleta & de $3.900 \AA$ a $2.000 \AA$ & - \\
\hline Raios X & de $100 \AA$ a $0,1 \AA$ & - \\
\hline Raios Gama & de $0,1 \AA$ a $0,0001 \AA$ & \\
\hline
\end{tabular}

\section{Os fótons da radiação eletromagnética}

Podemos dizer que toda radiação eletromagnética é composta de um feixe de partículas denominadas fótons. Os fótons podem ser considerados como partículas elementares. Assim, sempre que você estiver em contato com a luz, seja qual for o tipo de luz, por exemplo, do Sol, das estrelas ou de uma lâmpada elétrica, você estará em contato com essas partículas elementares. Essas partículas, os fótons, estão em todo o Universo com certeza e em todas as suas regiões. Eles são muito numerosos no Universo. Excedem em muito as demais partículas. Na realidade, quando falamos dos fótons estamos falando não de um ou dois, mas de bilhões e bilhões de fótons.

Se os fótons são tão numerosos, por que não sentimos os seus efeitos? Na realidade, podemos sentir os efeitos associados à presença de grande número de fótons. Por exemplo, só podemos ver um objeto ao nosso redor se tivermos luz à nossa disposição. Fótons com energia compreendida entre determinados valores, e desde que em grande número, compondo uma onda eletromagnética, são capazes de sensibilizar um dos nossos sentidos, o sentido da visão.

Os fótons são partículas que apresentam propriedades interessantes. Vejamos algumas dessas propriedades:

$\left.1^{\circ}\right)$ São partículas que não apresentam massa;

$2^{\circ}$ ) São partículas que possuem energia bem definida.

Einstein em 1905, quando explicou o Efeito Fotoelétrico, o qual the deu anos mais tarde em 1921 o prêmio Nobel de Física, inferiu que a energia de um fóton (ou quantum de energia) é dada pela expressão: $\mathbf{E}=\mathbf{n} \cdot \mathbf{h}$. $\mathbf{f}$, onde:

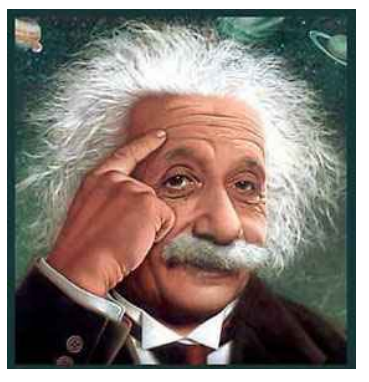

Albert Einstein (1879-1955) 
$E=$ representa a energia do fóton, medida em Joules $(\mathrm{J})$ ou elétron-volt $(\mathrm{eV})^{1}$;

$\mathbf{n}=$ representa o número de fótons;

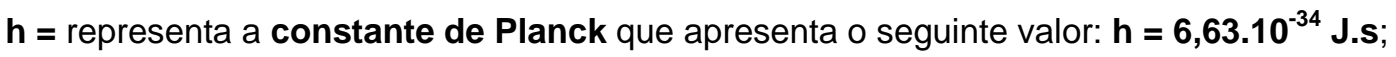

$\mathbf{f}=$ representa a freqüência da radiação, medida em $\operatorname{Hertz}(\mathrm{Hz})$.

Assim, podemos dizer cada fóton corresponde a um pequeno pacote de energia, um quantum, é por isso que podemos chamá-lo de "corpúsculo" ou "partícula" de energia. Um conjunto de fótons pode ser chamado de quanta de energia. Assim podemos perceber pela expressão acima que a energia de um fóton é quantizada, isto é, só pode assumir valores múltiplos de h.f (0, 1 hf; 2 hf; 3 hf, ...).

$\left.3^{\circ}\right)$ O fóton não tem carga elétrica. Esta é outra propriedade interessante do fóton. Isso quer dizer apenas que ele não é atraído ou repelido por ímãs ou por objetos eletrizados.

$4^{\circ}$ ) A velocidade de qualquer fóton, não importa sua energia, é de aproximadamente $3.10^{8} \mathrm{~m} / \mathrm{s}$, no vácuo. Desta forma, a velocidade do fóton é a velocidade limite na natureza, não havendo objeto capaz de se movimentar com velocidade maior que a de um fóton.

Diante destes fatos podemos concluir o seguinte:

Para cada radiação eletromagnética existirá um fóton de energia correspondente e com uma energia definida pela expressão $E=h$. f, movendo-se com uma velocidade $\mathrm{c}=3.10^{8} \mathrm{~m} / \mathrm{s}$.

\section{Os fótons e o modelo Atômico de Bohr}

Em 1913, o físico dinamarquês Niels Bohr (1885-1962), prêmio Nobel em 1922, propôs um novo modelo para o átomo, uma vez que o modelo antecessor conhecido como modelo planetário de Rutherford, apresentava inconsistências quanto ao movimento de um elétron em sua eletrosfera. Neste caso, o elétron deveria segundo a teoria eletromagnética de Maxwell, emitir radiação eletromagnética, caindo de encontro ao núcleo, pois era o que previa a teoria para uma carga acelerada. Porém, isso de fato não ocorria, pois as eletrosferas dos átomos são estáveis. Assim, evidenciou-se a necessidade de se propor um novo modelo atômico.

O modelo atômico de Bohr postulava que, para a eletrosfera de um átomo só podem existir determinados níveis de energia, denominados de estados estacionários ou quânticos: a cada um desses estados corresponde uma determinada energia. Em seu modelo, Bohr propôs que, em um estado estacionário, o átomo não emite radiação. Assim, sua eletrosfera mantém-se estável. Experimentos realizados em 1914 por James Frank (1882-1964) e Gustav Hertz (1887-1975), ambos físicos alemães, confirmaram a existência dos estados estacionários.

\footnotetext{
${ }^{1}$ Um elétron-volt (eV) corresponde a energia necessária para que um elétron, com carga de $1,6.10^{-19} \mathrm{C}$, seja acelerado ao atravessar uma diferença de potencial de $1 \mathrm{~V}$. Assim temos: $1 \mathrm{eV}=1,6.10^{-19} \mathrm{~J}$ ou $1 \mathrm{~J}$ $=6,25.10^{18} \mathrm{eV}$. A unidade $\mathrm{eV}$ é muito utilizada, assim como seus múltiplos: $\mathbf{k e V}$ (quiloelétron-volt) e $\mathrm{MeV}$ (megaelétron-volt). Assim temos: $1 \mathrm{keV}=1.000 \mathrm{eV}=10^{3} \mathrm{eV}$ e $1 \mathrm{MeV}=1.000 .000 \mathrm{eV}=10^{6} \mathrm{eV}$.
} 
Bohr também postulou que todo átomo, ao passar de um estado estacionário para outro, emite ou absorve um quantum de energia igual à diferença entre as energias correspondentes aos dois estados, conforme mostra a figura ao lado. Assim, cada quantum de energia que é emitido ou absorvido, corresponde a fótons com uma freqüência (f) e energia (E) bem definidos pela relação $E=$ h.f.

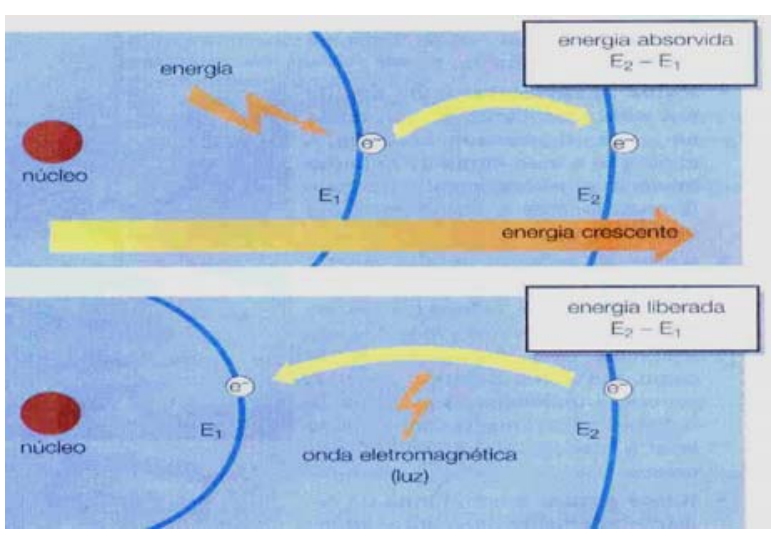

O átomo emitindo luz

Desta forma, percebemos que: o elétron "saltará" do nível de menor energia $\left(E_{1}\right)$ para o nível de maior energia $\left(E_{2}\right)$ se absorver um quantum h.f, tal que h.f $=E_{2}-E_{1}$; da mesma forma, o elétron ao retornar do nível de maior energia $\left(E_{2}\right)$ para o nível de menor energia $\left(E_{1}\right)$ se emitir um quantum de radiação h.f, tal que h.f $=E_{2}-E_{1}$.

Com base neste modelo e utilizando os postulados de Bohr, podemos explicar as diferentes colorações que temos na chama de uma vela da seguinte forma: Cada coloração que percebemos na chama de uma vela, corresponde a fótons de energias diferentes que são emitidos quando elétrons estão realizando transições entre níveis de maior energia para níveis de menor energia, conforme é apresentado nos postulados de Bohr. Assim, para cada coloração presente na chama de uma vela, temos fótons sendo emitidos com freqüência e energia bem definidos e que estão relacionados pela expressão: $\mathbf{E}=\mathbf{h} . \mathbf{f}$.

\section{Questões}

1-) Consultando a figura do espectro eletromagnético da primeira página deste texto, responda:

a) Quem tem maior freqüência: uma radiação ultravioleta ou uma radiação infravermelha?

b) Quem tem maior comprimento de onda: os raios $X$ ou as ondas de rádio?

c) Qual o intervalo de freqüência, aproximadamente, dos raios gama?

d) Que radiação tem um comprimento de onda da ordem de $10^{-2} \mathrm{~m}$ ?

2-) O que são fótons? Quando um átomo emite luz?

3-) Voltando a experiência sobre a análise da chama de uma vela realizada na aula anterior, percebemos que ela apresentou diferentes colorações, onde se destacaram as seguintes cores: amarela e azul. Determine através da expressão $\mathbf{E}=\mathbf{n}$. $\mathbf{h}$. f:

a) a energia, em Joules (J) e em elétron-volt (eV), de um fóton da luz amarela e da luz azul, sabendo que a freqüência da cor amarela é de $5,3 \cdot 10^{14} \mathrm{~Hz}$ e da cor azul é de $6,3 \cdot 10^{14} \mathrm{~Hz}$.

b) Compare-as e diga quem tem o maior e o menor valor de energia. Estes valores estão de acordo com o que foi discutido na aula anterior?

4-) Pesquise em qualquer livro didático de Física, qual o segundo Postulado da Teoria da Relatividade Especial de Einstein. Escreva-o em seu caderno. Procure dar um exemplo que ilustre o significado deste postulado.

(Dica: Pode ser feito um desenho ou esquema para facilitar a sua explicação) 


\section{Espectro Eletromagnético (Parte I)}

Cada onda ou radiação eletromagnética presente no espectro eletromagnético vistos na aula anterior, difere da outra, quanto a sua freqüência (f), comprimento de onda $(\lambda)$ e energia ( $E)$. Vamos analisar a partir desta aula as diferentes freqüências de onda e suas possíveis aplicações em nosso cotidiano. Nesta aula falaremos das ondas de rádio, essenciais às telecomunicações, das microondas presentes nos radares e fornos de microondas.

\section{Ondas de Rádio}

A região das ondas de rádio do espectro eletromagnético vai das ondas mais longas, cujo comprimento de onda é maior que o raio da Terra, até ondas com um comprimento de onda de um metro. As freqüências correspondentes, que vão desde alguns quilohertz ${ }^{1}(\mathrm{kHz})$ até centenas de megahertz ${ }^{2}(\mathrm{MHz})$, são os números que aparecem nos mostradores dos aparelhos de rádio. Existem várias subdivisões das ondas de rádio como $A M$ e $F M$, que representam formas diferentes de se enviar o sinal, porém todas podem se propagar a grandes distâncias na atmosfera sendo por isso usadas em sistemas de comunicações.

Já aconteceu de você estar dirigindo à noite e captar o sinal de rádio de uma estação a mais de $2.000 \mathrm{~km}$ de distância? Se já passou por esta experiência, você conhece em primeira mão a capacidade das ondas de rádio de viajarem a longas distâncias na atmosfera. $\mathrm{O}$ movimento oscilatório dos elétrons em uma antena de metal pode gerar uma onda de rádio do tipo usada em telecomunicações. A aceleração dos elétrons produz ondas eletromagnéticas do mesmo modo que jogar uma pedra em um lago produz ondulações. Quando estas ondas encontram um outro objeto metálico (a antena receptor de um rádio, por exemplo), o campo elétrico da onda faz os elétrons do objeto oscilarem. O movimento dos elétrons constitui uma corrente elétrica ${ }^{3}$ que os circuitos eletrônicos de um receptor de rádio ou um simples rádio de Galena $^{4}$, podem transformar em um sinal de rádio. Este sinal, por sua vez, produz uma onda sonora ao ser usado um alto-falante.

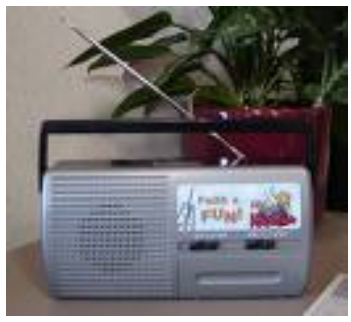

Rádio receptor AM e FM

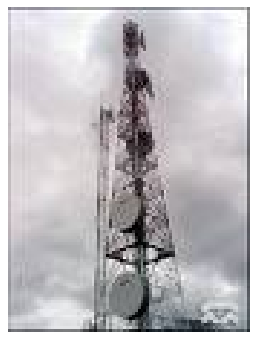

Antena transmissora

Quase todos os materiais de construção são pelo menos parcialmente transparentes às ondas de rádio, sendo por isso que podemos ouvir rádio dentro de uma casa sem nenhum

\footnotetext{
${ }^{1}$ Quilohertz $(\mathrm{kHz})=1.000$ Hertz (mil oscilações por segundo).

${ }^{2}$ Megahertz $(\mathrm{MHz})=1.000 .000$ Hertz (um milhão de oscilações por segundo).

${ }^{3}$ Corrente elétrica: movimento organizado de cargas elétricas no interior de um metal. Em um fio esse movimento organizado é constituído de elétrons livres.

${ }^{4}$ Radio de Galena: rádio mais simples de ser montado para captação das ondas de rádio.
} 
problema. Nos túneis, porém, ou nas cidades cercadas de montanhas, a atenuação das ondas de rádio por uma camada muito espessa de rocha pode dificultar a recepção.

No Brasil, o governo reserva faixas de freqüências do espectro eletromagnético para vários usos. A cada estação de rádio comercial é outorgada uma freqüência, o mesmo acontece com os canais de televisão. Outras partes do espectro eletromagnético também são usadas para comunicações particulares (polícia, bombeiros, telefones celulares, etc.). $\mathrm{Na}$ verdade, o direito de usar uma faixa do espectro eletromagnético para comunicações é muito valorizado, já que existe uma faixa com número limitado de freqüências e muitas pessoas estão interessadas em utilizá-las.

As rádios AM (Amplitude Modulada) cobrem faixas de operação entre $530 \mathrm{kHz}$ e 1600 $\mathrm{kHz}$, enquanto que as rádios FM operam com freqüências entre $88 \mathrm{MHz}$ e $110 \mathrm{MHz}$. Como as ondas transmitidas em AM são de comprimento de onda maiores, elas conseguem ir a distâncias maiores que as ondas transmitidas em FM.

\section{Microondas}

As microondas são ondas eletromagnéticas com comprimento de onda entre $1 \mathrm{~m}$ e $1 \mathrm{~mm}$, com freqüências compreendidas, aproximadamente, entre $10^{8} \mathrm{~Hz}$ e $10^{11} \mathrm{~Hz}$. Como as microondas se propagam em linha reta, exigem uma visada direta entre as antenas de transmissora e receptora. Os satélites transmitem sinais à Terra através de microondas. As microondas também são usadas para transmitir sinais telefônicos e de televisão. As antenas parabólicas usadas pelos assinantes de TV via satélite e as antenas em forma de cone nas torres de retransmissão que se vêem ao longo das estradas são antenas de microondas.

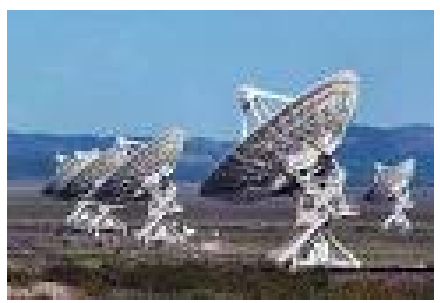

Antenas Parabólicas

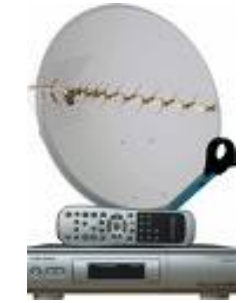

Receptor via satélite

As propriedades das microondas as tornam ideais para uso em aparelhos de radar. A maioria dos objetos reflete microondas como um espelho reflete a luz visível. Enviando pulsos de microondas e detectando os pulsos refletidos, os aparelhos de radar mais sofisticados são capazes de determinar a direção, a distância (pelo tempo que os pulsos levam para ir e voltar) e a velocidade de qualquer alvo. Os radares militares modernos são tão sensíveis que conseguem rastrear uma mosca a dois quilômetros de distância. Para fazer frente a esta tecnologia, os projetistas de aeronaves desenvolveram aviões "invisíveis" que utilizam materiais especiais, formas angulosas e sistemas de interferência eletrônica para não serem detectados. 


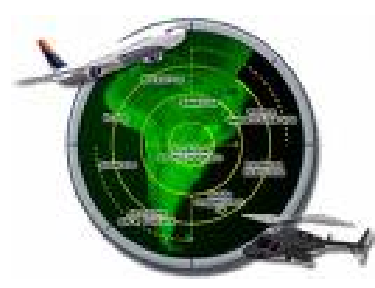

Radar

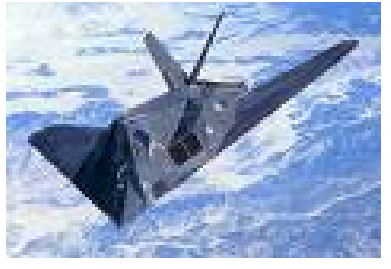

Avião invisível

As mesmas ondas usadas na telefonia, na televisão e no radar também servem para cozinhar os alimentos. Nos fornos de microondas, um circuito especial faz os elétrons oscilarem (agitarem) rapidamente, gerando microondas. Estas microondas são guiadas para o compartimento principal do forno, que é feito de um material que espalha as microondas. Assim, as ondas permanecem no interior do forno até serem absorvidas por algum objeto.

Acontece que as microondas são fortemente absorvidas por moléculas de água. Isto significa que a energia das microondas é absorvida pela água contida nos alimentos e convertida em calor, cozinhando os alimentos. Podemos pensar da seguinte maneira: as microondas fazem as moléculas de água agitarem-se muito, o que acaba gerando o calor citado anteriormente. As microondas não esquentam papel e vidro, pois estes materiais não contêm muitas moléculas de água.

Os objetos metálicos refletem as microondas e é por isso que alguns fornos de microondas contém um ventilador com pás de metal, que ajudam a espalhar as microondas. É por isso também que não se deve embrulhar alimentos em papel alumínio antes de colocá-lo no forno de microondas, pois o metal funcionaria como uma barreira para as microondas, aumentando consideravelmente o tempo de cozimento.
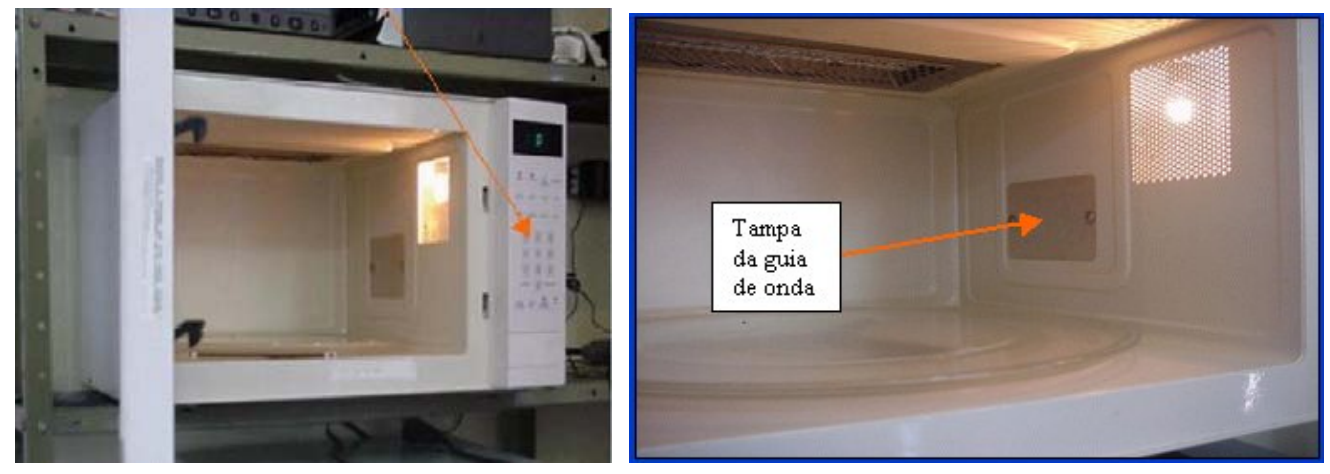

Interior do aparelho e a saída das microondas

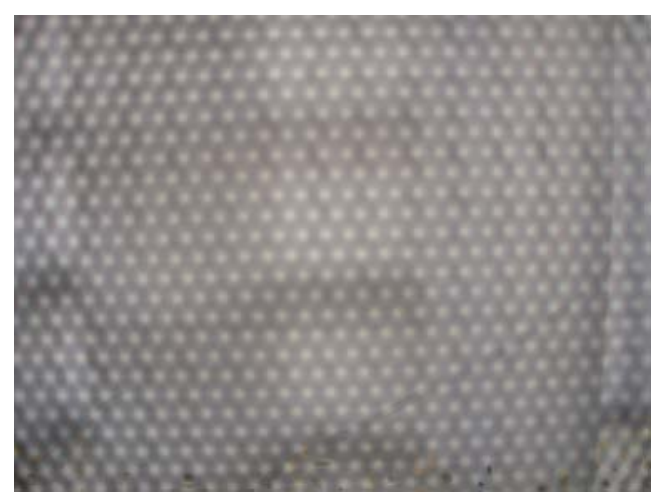

Grade de proteção da porta do aparelho
Algo muito interessante quanto ao forno de microondas é a presença de uma grade na porta do aparelho. Esta grade é mais uma proteção, além das muitas que os aparelhos já trazem, para impedir que as microondas consigam atravessar a porta e cheguem até o meio externo. 
A grade metálica embutida no vidro serve como uma barreira que permite atenuar a intensidade com a qual as microondas chegam ao meio exterior do forno, o que evita literalmente o cozimento de qualquer objeto que contenha água em sua proximidade, inclusive as regiões do corpo de uma pessoa. Testes como colocar a metade de uma maçã sobre o aparelho, próximo à porta, e a outra metade da maçã nas proximidades da porta na parte de baixo, podem ajudar a diagnosticar se o aparelho e/ou porta estão com algum vazamento das microondas.

\section{Questões}

1-) É possível gerar ondas de rádio com uma pilha e um pedaço de fio metálico? Em caso de positivo, explique como isso é possível.

2-) Cite a freqüência de uma rádio que você conhece em $\mathrm{Hz}, \mathrm{kHz}$ e $\mathrm{MHz}$.

3-) Quem tem maior energia: as ondas de rádio ou as microondas? Justifique.

4-) Digamos que por algum defeito, você conseguisse ligar um microondas com a porta aberta. Seria possível cozinhar o braço de uma pessoa com um aparelho de microondas? Por quê?

5-) Você já reparou na grade que existe na porta de um forno convencional a gás? Qual a sua finalidade?

6-) Sabendo que a freqüência das microondas que o aparelho gera é de aproximadamente $2,45 \mathrm{GHz}$, qual a energia dessas microondas, em Joule (J)?

(Dica: $1 \mathrm{GHz}=10^{9} \mathrm{~Hz}$ e $\mathrm{E}=\mathrm{h}$. f, onde $\mathrm{h}=6,63 \cdot 10^{-34} \mathrm{~J} . \mathrm{s}$ ) 


\section{Espectro Eletromagnético (Parte II)}

Nesta aula falaremos dos raios infravermelhos que são muito utilizados em controle remoto e da luz visível, uma radiação que consegue sensibilizar o nosso sentido da visão.

\section{Raios Infravermelhos}

Os raios infravermelhos são ondas eletromagnéticas com comprimento de onda entre $1 \mathrm{~mm}^{1}$ e $1 \mu \mathrm{m}^{2}$, com freqüências desde $10^{11} \mathrm{~Hz}$ até $10^{14} \mathrm{~Hz}$, aproximadamente. Receberam esta nomenclatura, pois elas têm freqüência abaixo da correspondente à cor vermelha. Nossa pele, que absorve raios infravermelhos, funciona como uma espécie de detector natural para esses raios. Sentimos a presença de raios infravermelhos quando aproximamos as mãos de uma fogueira ou do elemento de um aquecedor (resistência) de ambiente.

Os objetos quentes, assim como nosso corpo, emitem raios infravermelhos, e este fato é usado em aplicações civis e militares. Um ferro de passar ao ser ligado na rede elétrica tem uma resistência elétrica que ao se aquecer, emite radiação infravermelha. Por isso, os raios infravermelhos são também chamados de ondas de calor e podem ser visualizados com o auxílio de filme sensível a esses raios.

Detectores de infravermelho são empregados para guiar mísseis na direção de aviões inimigos, aproveitando o calor das turbinas, e também para "ver" soldados e veículos inimigos à noite. Insetos, como mosquitos e mariposas, e outros animais noturnos, como cobras e os gambás, são sensíveis aos raios infravermelhos, o que lhes permite localizar a presa mesmo na escuridão total.
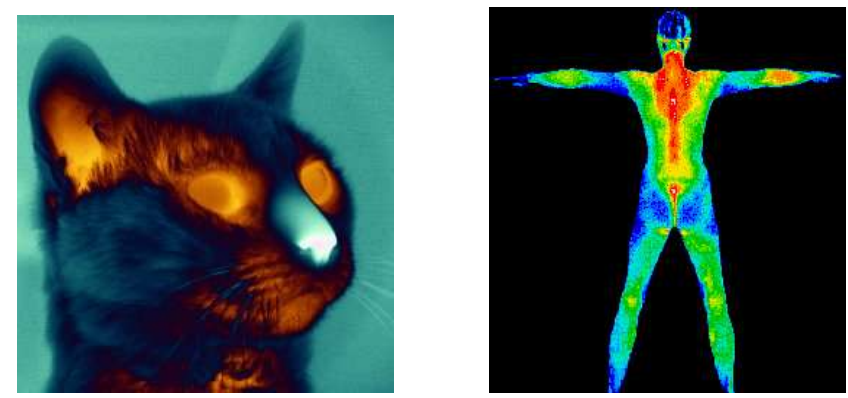

As regiões quentes do corpo humano ou de um animal, aparecem em vermelho usando uma análise pelo infravermelho

Os detectores de infravermelho também são usados para localizar vazamentos de calor em casas e edifícios, em localidades onde há calefação ambiental. Quando fotografamos uma casa à noite usando um filme sensível aos raios infravermelhos, os lugares por onde o calor está escapando aparecem como pontos claros. Esta informação pode ser usada para reduzir as perdas térmicas e com isso economizar energia. Os cientistas também usam detectores de infravermelho para inspecionar os vulcões. O aparecimento de um ponto quente pode ser sinal de que uma erupção está para acontecer.

\footnotetext{
${ }^{1} 1$ milílmetro $(1 \mathrm{~mm})=0,001 \mathrm{metro}=10^{-3} \mathrm{~m}$.

21 micrômetro $(1 \mu \mathrm{m})=0,000001$ metro $=10^{-6} \mathrm{~m}$.
} 
Atualmente, em muitas casas espalhadas pelo mundo, dispomos de um dispositivo que se utiliza dos raios infravermelhos para comandar um equipamento. Este equipamento é o controle remoto dos aparelhos de televisão. No microcircuito do controle remoto, cada função está associada a uma seqüência de pulsos diferentes. Esta seqüência é composta de 0 e 1, o chamado código binário, o mesmo utilizado pelos computadores. Quando você aperta um botão, o circuito ativa um diodo emissor de luz, neste caso de luz infravermelha, que envia uma dessas seqüências para um detector no aparelho de televisão. A seqüência em geral é repetida cinco vezes por segundo para assegurar que seja reconhecida.

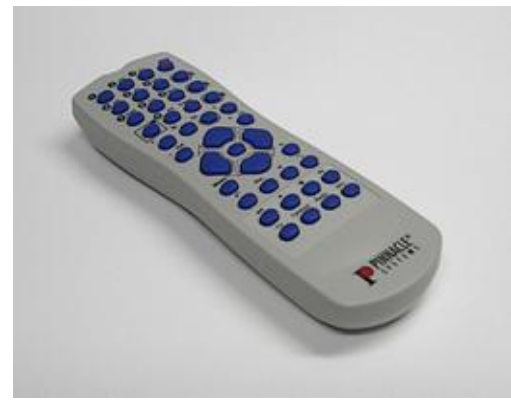

Controle Remoto Infravermelho

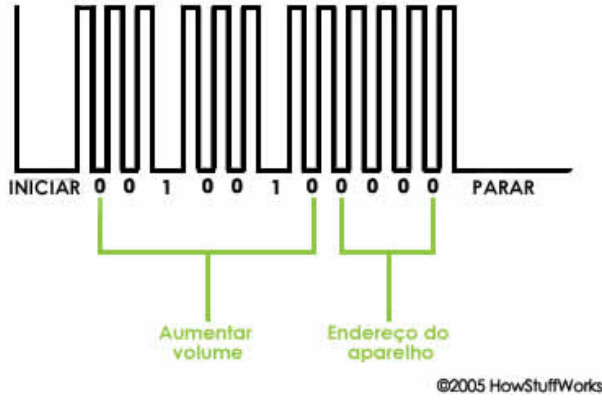

Exemplo de seqüência de pulsos

\section{Luz Visível}

Todas as cores do arco-íris estão presentes na luz visível, cujos comprimentos de onda vão de $700 \mathrm{~nm}^{3}$ (vermelho) até $400 \mathrm{~nm}$ (violeta), com freqüências que vão de 4,3.10 ${ }^{14} \mathrm{~Hz}$ até $7,5.10^{14} \mathrm{~Hz}$. Este intervalo de comprimentos de onda constitui uma pequena fração do espectro eletromagnético. Podemos perceber que a luz branca é a mistura de várias cores fazendo, por exemplo, a luz branca do Sol passar através de um prisma ${ }^{4}$ o que resulta nas cores do espectro visível. Os seres humanos percebem o espectro da luz visível como uma série de faixas coloridas. A sensibilidade do olho humano varia de acordo com o comprimento de onda. Nossa percepção é máxima na região do amarelo.

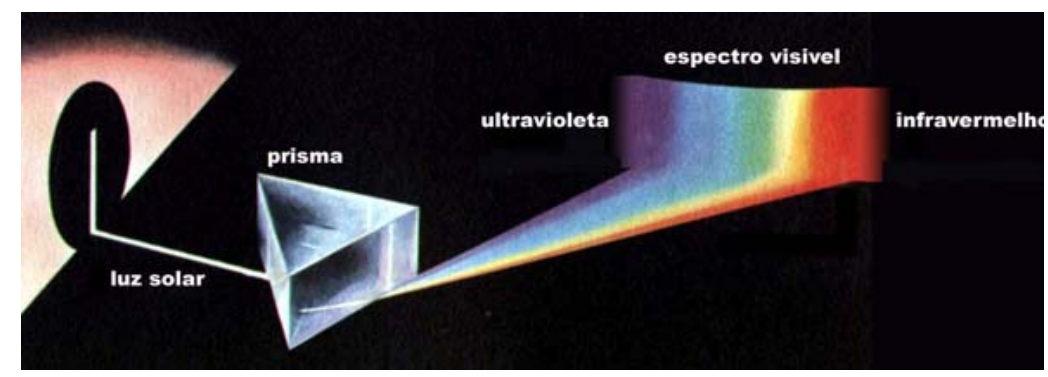

Espectro Visível da Luz Solar

Nossos olhos podem distinguir muitas cores diferentes, mas estas cores não têm nenhum significado especial exceto em nossa percepção. Na verdade, as cores do arco-íris (vermelho, laranja, amarelo, verde, azul, anil e violeta) correspondem a regiões do espectro da luz visível cuja largura varia de cor para cor. As partes vermelha e azul do espectro são mais

\footnotetext{
${ }^{3} 1$ nanômetro $(1 \mathrm{~nm})=0,000000001$ metro $=10^{-9} \mathrm{~m}$.

${ }^{4}$ Prisma: elemento que permite fazer a dispersão (decomposição) da luz branca através da difração.
} 
extensas, com $50 \mathrm{~nm}$ de largura, isto significa que muitos comprimentos de onda diferentes são percebidos como azul ou vermelho. A parte amarela do espectro é bem mais estreita, cobrindo apenas a faixa de 570 a $590 \mathrm{~nm}$.

Por que nossos olhos seriam sensíveis a uma parte tão pequena do espectro eletromagnético? Como a luz solar é particularmente intensa nesta região do espectro, alguns biólogos acreditam que a evolução natural tenha tornado nossos olhos sensíveis a estes comprimentos de onda para aproveitar melhor possível a luz do Sol. Nossos olhos estão adaptados à luz que existe na superfície do planeta durante o dia. Os olhos de animais que caçam à noite, como corujas e gatos, são mais sensíveis aos raios infravermelhos, que fazem os animais de sangue quente se destacarem na paisagem.

O mais conhecido detector de luz é aquele que levamos conosco o tempo todo: o olho humano. Os olhos são órgãos extremamente complexos, que convertem a radiação eletromagnética em imagens através de uma combinação de processos físicos e químicos.

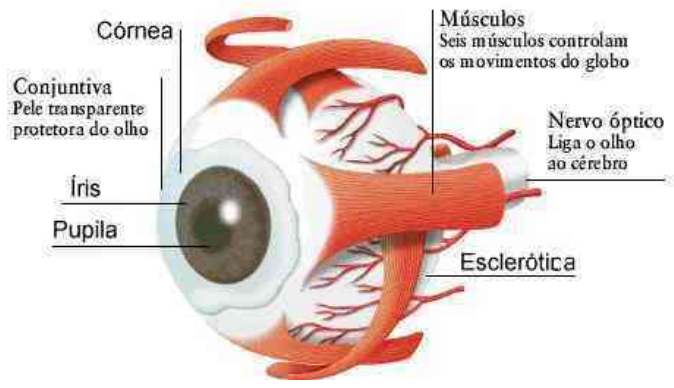

Detalhes do olho humano

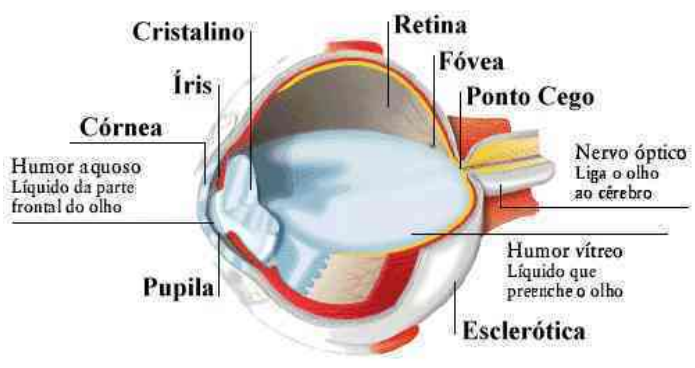

Conjunto ótico perfeito para formar a imagem

As ondas luminosas entram no olho através de uma lente natural chamada de cristalino, cuja espessura é controlada por músculos especiais. O cristalino do olho refrata (desvia) os raios luminosos, focalizando-os nas células receptoras da retina, uma membrana que reveste a parte posterior do olho. A retina contém dois tipos de células, os cones e os bastonetes.

Os bastonetes são mais sensíveis, mas respondem apenas à intensidade da luz e é graças a eles que podemos ver à noite. Quanto aos cones eles são de três tipos, sensíveis ao vermelho, ao azul e ao verde, permitindo que consigamos distinguir as cores.

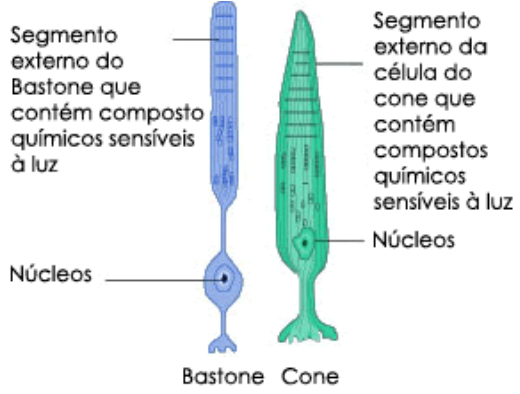

O mais surpreendente é que a estimulação combinada desses três grupos de cones é capaz de produzir toda a extensa gama de cores que o ser humano enxerga. A ausência de qualquer um desses tipos resulta numa doença chamada daltonismo ${ }^{5}$, que é a cegueira à determinada cor. Por enquanto, o daltonismo é um mal sem cura nem prevenção. Os pesquisadores sabem apenas que o problema tem origem genética e atinge principalmente os

\footnotetext{
${ }^{5}$ Daltonismo: doença descoberta em 1794 pelo físico John Dalton, que era portador desta enfermidade e daí veio o nome em homenagem ao seu descobridor.
} 
homens. $\mathrm{Na}$ realidade, o funcionamento das células nervosas que compõem a retina e sua conexão com o cérebro ainda são campos nebulosos da oftalmologia. Por isso, doenças que atingem essa região costumam provocar cegueira irreversível.

A energia das ondas luminosas ao penetrar no olho produz mudanças complexas nas moléculas dos bastonetes e cones, iniciando uma série de reações que têm como resultado um sinal elétrico. Este sinal é transmitido ao cérebro pelo nervo óptico, que o interpreta e gera a imagem que estamos vendo.

\section{Questões}

1-) Por que não podemos enxergar os raios infravermelhos?

2-) Ao ligarmos o forno do fogão de casa, estamos fazendo uma reação química de combustão, pois estamos queimando um gás na presença de oxigênio do ar. Que tipo de radiação é liberada nesta reação?

3-) Como seria possível a partir de um CD, desses que usamos para gravar músicas, conseguir um espectro semelhante ao da luz visível?

4-) O arco-íris geralmente se forma após as chuvas. Que cores compõem o arco-íris? Como explicar o seu aparecimento?

5-) Você é daltônico? Não sabe? Para detectar o daltonismo, usa-se o teste de Ishihara, em que pontilhados coloridos formam determinados números ou letras. Na figura abaixo, existe um número. Que número é este? Uma pessoa normal consegue enxergá-lo sem maiores problemas!

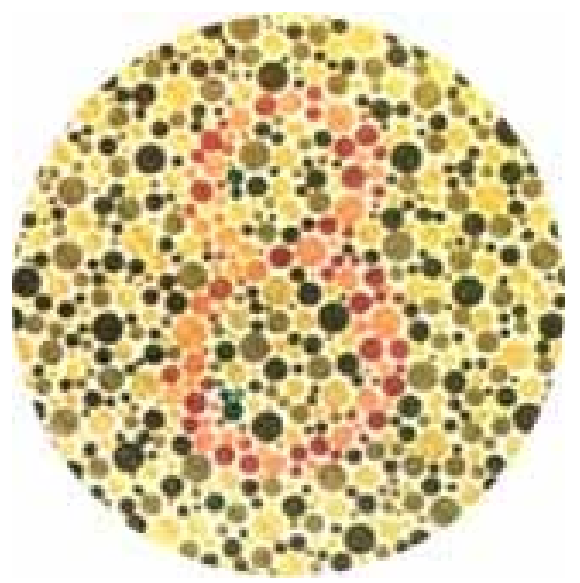

6-) Nosso corpo é uma máquina fantástica. Ela possui sensores capazes de detectar a presença da radiação infravermelha e da luz visível. Estes sensores são, na verdade, os nossos sentidos. Assim, quais são esses sentidos para cada radiação? 


\section{Espectro Eletromagnético (Parte III)}

Nesta aula estudaremos os raios ultravioleta que são raios muito utilizados em câmaras de bronzeamento artificial, dos raios $X$ que são essenciais para os diagnósticos médicos, além dos raios gama que são os raios mais energéticos liberados na explosão de uma bomba atômica.

\section{Raios Ultravioleta (UV)}

Os raios ultravioleta são ondas eletromagnéticas com comprimentos de onda entre $400 \mathrm{~nm}$ e $100 \mathrm{~nm}$, correspondentes a freqüências que alcançam até $10^{18} \mathrm{~Hz}$. Esta denominação é devido a sua freqüência ser acima do violeta da luz visível. A energia contida nos raios ultravioleta de grande comprimento de onda é suficiente para estimular a produção de um pigmento nas células da pele conhecido como melanina. A este fenômeno de estimulação damos o nome de bronzeamento, sendo ele responsável pela proteção da nossa pele quanto à exposição exagerada aos raios do Sol, por exemplo. Esta parte de baixa energia dos raios ultravioleta não apresenta riscos para a saúde.

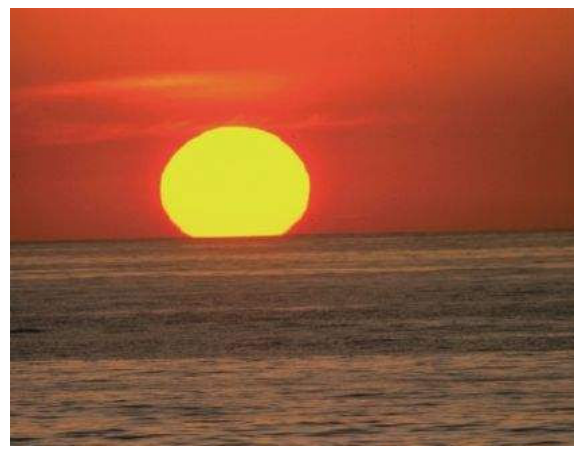

O Sol emite muito ultravioleta

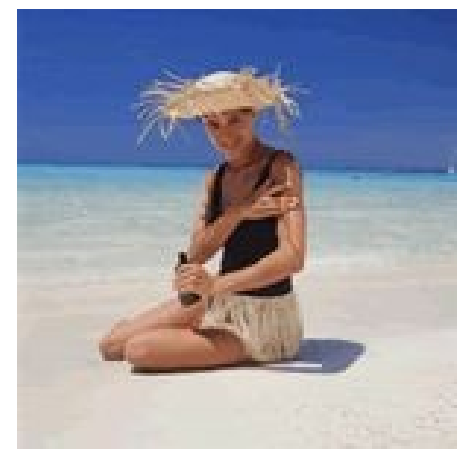

Pessoa passando um filtro solar

Os raios ultravioleta de pequeno comprimento de onda, por outro lado, possuem uma energia bem maior, suficiente para danificar as células da pele, causando queimaduras e câncer de pele em seres humanos. Daí a necessidade de proteger a pele usando um protetor solar. O poder destrutivo dos raios ultravioleta é usado nos hospitais para esterilizar instrumentos cirúrgicos.

O Sol produz raios ultravioleta em grande quantidade. Felizmente, a atmosfera da Terra, e particularmente a camada de ozônio, absorve grande parte desses raios, protegendo assim os seres vivos que habitam o nosso planeta. Mesmo assim, as pessoas que passam muito tempo expostas ao Sol devem proteger a pele passando um filtro solar, que é transparente à luz visível, mas absorve os perigosos raios ultravioleta.

A radiação ultravioleta que atinge a Terra se divide em radiação UVA e UVB, embora haja também os raios UVC, que não chegam até o nosso planeta. A radiação UVA, é a maior parte do espectro ultravioleta e possui intensidade constante durante todo o ano, atingindo a pele praticamente da mesma forma durante o inverno ou o verão. Sua intensidade também não varia muito ao longo do dia, sendo pouco maior entre 10 e 16 horas que nos outros horários. 
Os raios UVA penetram profundamente na pele, sendo os principais responsáveis pelo fotoenvelhecimento. Tem também importante participação nas fotoalergias e também predispõe a pele ao surgimento do câncer. É interessante saber que o UVA também está presente nas câmaras de bronzeamento artificial, em doses mais altas do que na radiação proveniente do Sol.

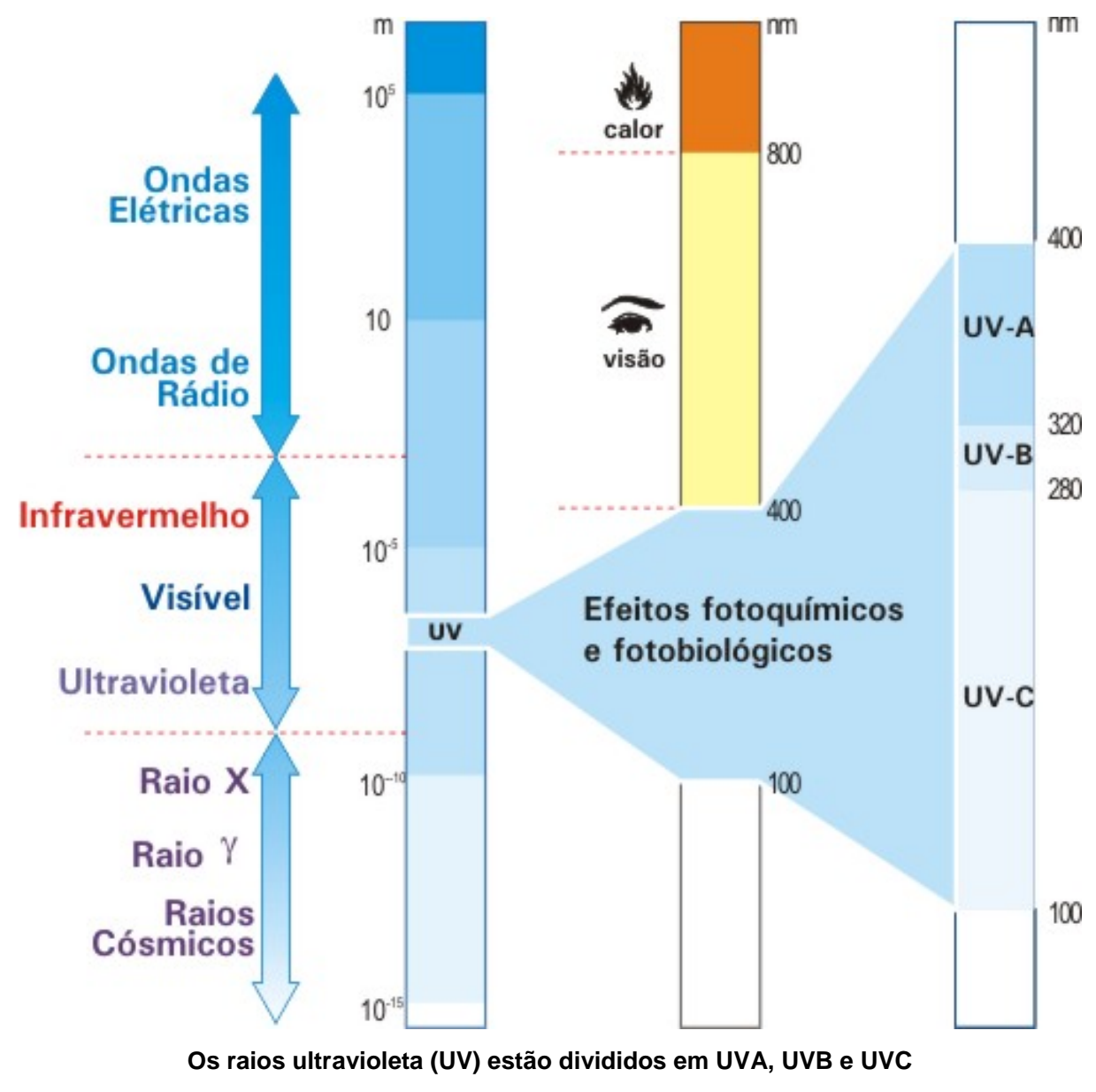

A radiação UVB já tem uma incidência bem maior durante o verão, especialmente entre 10 e 16 horas. Os raios UVB penetram superficialmente na pele e são os causadores das queimaduras solares, que são as principais responsáveis pelas alterações celulares que predispõem ao câncer de pele. Assim, fica o alerta para o fato de que, sendo apenas os raios UVB que causam as queimaduras solares, o fato da pessoa não ter ficado vermelha não significa que não tenha sido atingida danosamente pela radiação UVA. Aquele sol de inverno que pareceu não causar problemas porque você não se queimou nada, na verdade também está prejudicando sua pele favorecendo, principalmente, o seu envelhecimento, da mesma forma que as câmaras de bronzeamento artificial.

Nas câmaras de bronzeamento artificial a quantidade de UVA emitida pode chegar a ser 10 vezes maior que a da luz solar. Pode-se imaginar o dano causado à pele por este tipo de tratamento. Este dano, somente aparece muitas vezes com o passar dos anos. Desta forma, especialistas afirmam que o uso destas câmaras para bronzeamento deve ser evitado e o uso de filtro solar imprescindível a tempos de exposição ao Sol muito prolongados. 
Os filtros solares podem ser químicos (absorvem os raios UV) ou físicos (refletem os raios UV). É comum a associação de filtros químicos e físicos para se obter um filtro solar de FPS mais alto. A sigla FPS significa Fator de Proteção Solar e todo filtro solar tem um número que determina o seu FPS, que pode variar de 2 a 60 (até agora, nos produtos comercializados no Brasil). O FPS mede a proteção contra os raios UVB, responsáveis pela queimadura solar, mas não medem a proteção contra os raios UVA.

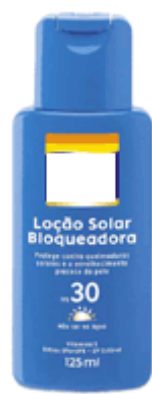

Filtro solar

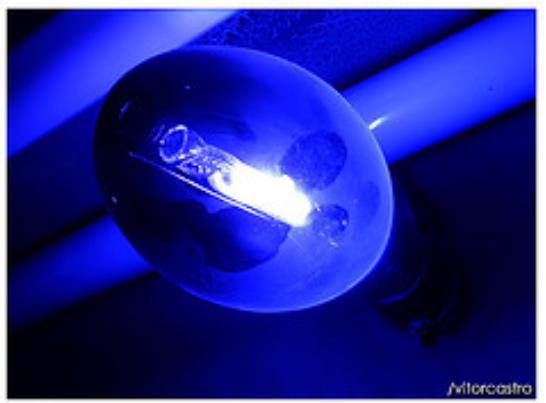

Lâmpada de luz negra usada em festas

Na matéria, os átomos de algumas substâncias absorvem raios ultravioleta e emitem parte da energia na forma de luz visível. Convém lembrar que tanto a luz visível como os raios ultravioleta são ondas eletromagnéticas, mas a luz visível tem um comprimento de onda maior, e portanto uma energia menor que a dos raios ultravioleta. Este fenômeno, conhecido como fluorescência, é responsável pelos efeitos de "luz negra" tão populares em casas noturnas e festas. Este fenômeno tem explicação no átomo, nas transições de elétrons entre níveis de energia e o tempo de transição entre esses níveis.

Hoje os raios ultravioleta são usados também em máquinas que permitem identificar cédulas de dinheiro falsas, pois a tinta usada nas cédulas falsas reflete esta luz de forma diferente de uma cédula verdadeira.

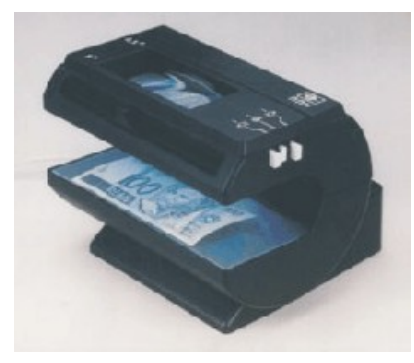

Máquina identificadora de cédulas falsas de dinheiro com UV

\section{Raios X}

Os raios X são ondas eletromagnéticas com comprimento de onda entre 100 nanômetros e 0,1 nm. Estas ondas de alta energia podem atravessar, com maior ou menor atenuação, quase todos os materiais. Por esta razão, os raios $X$ são muito usados na medicina para obter imagens de ossos e órgãos internos. Os raios $X$ também são usados na indústria para inspecionar peças em busca de trincas e outros defeitos. 


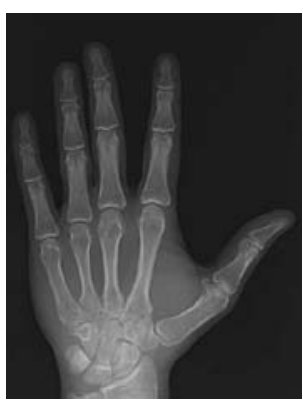

Radiografia da mão

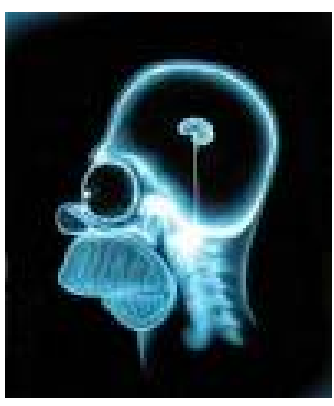

Radiografia da cabeça de um Homo Sapiens

Os tubos de raios $X$ usados por médicos e dentistas se parecem com lâmpadas incandescentes. Em uma extremidade do tubo, existe um filamento de tungstênio que é aquecido a altas temperaturas por uma corrente elétrica, como o filamento de uma lâmpada. $\mathrm{Na}$ outra extremidade do tubo existe uma placa de metal. Para produzir os raios X, é aplicada uma alta tensão entre o filamento e a placa metálica, mantida em um potencial positivo, que faz com que os elétrons que são emitidos pelo filamento sejam acelerados e se choquem violentamente com o metal. A súbita desaceleração dos elétrons ao penetrar no material, resulta na produção das ondas eletromagnéticas de alta energia que chamamos de raios $\mathrm{X} e$ que ao atravessarem os materiais, por exemplo, a nossa mão, conseguem gerar a imagem dos ossos em uma chapa fotográfica (radiografia).

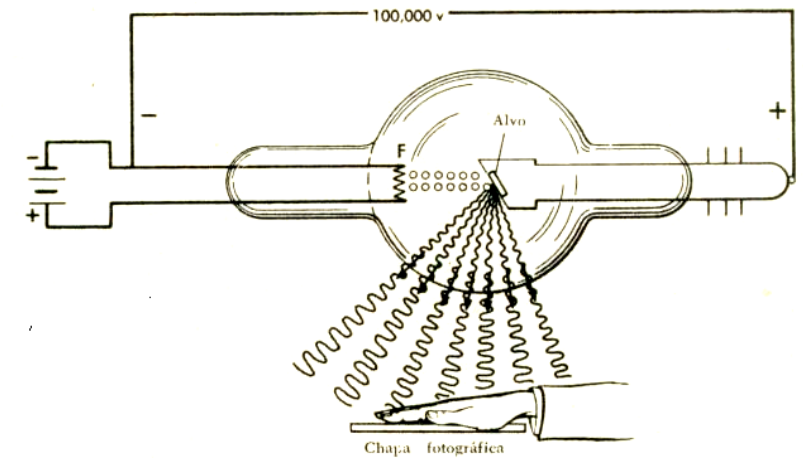

Tubo de raios $X$ : elétrons são desacelerados ao colidirem com a placa de metal e emitem raios $X$

Dentre as muitas das aplicações em potencial dos raios $\mathrm{X}$, como em aeroportos, estudos estruturais de cristais muito pequenos e inspeções de peças muito grandes, estas não podem ser concretizadas por causa da intensidade relativamente pequena das fontes de raios $X$ convencionais. No entanto, está sendo feito um grande esforço para desenvolver fontes mais potentes de raios $X$. Uma destas instalações encontra-se em Campinas e é conhecido como Luz Sincroton.

Para um aprofundamento maior sobre os raios $X$, recomendamos a leitura do texto suplementar: A Descoberta dos Raios X. Este texto foi extraído do trabalho de dissertação de mestrado de Maxwell Roger Siqueira e apresenta um excelente caráter histórico acerca da descoberta dos raios $\mathrm{X}$ e o caminho seguido por seu descobridor.

\section{Raios Gama}


As ondas de maior energia do espectro eletromagnético são chamadas de raios gama. Os comprimentos de onda variam entre $0,1 \mathrm{~nm}$ e $1 \mathrm{pm}^{1}$. Os raios gama se originam dentro do núcleo atômico devido a transições nucleares, por exemplo, quando um elemento radioativo sofre uma desintegração. O processo de desintegração de um elemento radioativo será estudado no bloco sobre as radiações corpusculares.

Os raios gama são muito usados na medicina. Alguns tipos de diagnósticos envolvem a administração ao paciente de uma substância radioativa que emite raios gama. Se esta substância se acumula nos lugares onde o osso está se regenerando, por exemplo, os médicos podem acompanhar o processo observando os lugares onde são emitidos os raios gama. Os detectores de raios gama utilizados nesta forma específica de medicina nuclear são muito caros e volumosos. Os médicos também usam os raios gama para o tratamento de câncer. Neste tipo de tratamento, os raios gama são usados para matar as células cancerosas que não podem ser removidas cirurgicamente.

A cirurgia com raios gama está se revelando um método promissor para tratar certos problemas do cérebro, como tumores benignos e malignos e malformações dos vasos sanguíneos. O método utiliza um feixe de raios gama focalizados no tumor ou na malformação. Este feixe destrói as células dos tumores ou vasos malformados. Os raios gama são emitidos por uma fonte radioativa, geralmente de cobalto-60 ou césio-137. A cirurgia com raios gama é não-invasiva, indolor, não provoca hemorragia e quase sempre pode ser realizada com anestesia local.

Entretanto os raios gama também podem trazer sérias conseqüências quando usados de forma inadequada. Os efeitos que eles causaram sobre as centenas de pessoas que sobreviveram a acidentes como os de Goiânia em 1987 com o césio-137, Chernobyl na Ucrânia em 1986 com a explosão do reator nuclear e as bombas atômicas jogadas sobre as cidades de Hiroshima e Nagasaki em 1945, ainda nos trazem na lembrança, os efeitos devastadores dessa forma de radiação. Isso se deve ao fato de que estes raios por serem muito energéticos, conseguem atravessar o nosso corpo sem maiores dificuldades, conseguindo atingir as cadeias de DNA presentes no núcleo das células e alterando-as, causando muitas vezes as chamadas mutações genéticas tão exploradas em filmes e desenhos como "Hulk" e "Quarteto Fantástico". Também podem causar a manifestação de algum tipo de câncer.

\section{Raios Cósmicos}

Os raios cósmicos foram identificados no início do século $X X$ em pesquisas sobre a condutividade elétrica em gases contidos em recipientes fechados. Nessa ocasião, percebeuse que, mesmo com todas as devidas precauções, o ar contido num recipiente sempre exibia alguma condutividade elétrica resultante da ionização das moléculas dos gases componentes. Essa ionização e a conseqüente condutividade elétrica que dela se origina ocorriam em

\footnotetext{
${ }^{1} 1$ picômetro $(1 \mathrm{pm})=0,000000000001$ metro $=10^{-12} \mathrm{~m}$.
} 
qualquer lugar, mesmo na superfície do mar, onde a radioatividade natural, emitida por componentes minerais da superfície terrestre, é desprezível. A única forma de reduzi-la, já que não era possível eliminá-la, era isolar o recipiente do exterior por grossas armaduras de chumbo. Devia existir, portanto, uma radiação natural mais penetrante que qualquer outra até então conhecida.

De 1911 a 1912, o físico austríaco Victor Hess (1883-1964) efetuou uma série de ascensões em balão a altitudes de até $5.000 \mathrm{~m}$, realizando inúmeras pesquisas. Concluiu então que essa radiação se origina do espaço cósmico, daí o nome de raios cósmicos.

Hoje podemos definir os raios cósmicos como sendo radiações de altíssima energia, da ordem de de 100 a 1000 trilhões de elétron-volts, que chegam à Terra, vindas do espaço, cujas fontes estão na longínqua constelação Cygnus, situada a 37 mil anos-luz ${ }^{2}$ da Terra.

\section{Questões}

1-) Que tipos de radiações o Sol emite? Que sensores naturais permitem que nós "enxerguemos" essas radiações?

2-) Para que serve um filtro solar? Somente as pessoas de pele clara é que devem usar filtro solar? Justifique.

3-) Qual das radiações UV é a mais perigosa? Por quê?

4-) Como são gerados os raios X? Como são gerados os raios gama? Qual o mais energético?

5-) Em desenhos e filmes, a radiação gama pôde transformar uma pessoa em um monstro. Isso ocorreu, por exemplo, no desenho do Hulk, onde o doutor David Banner foi bombardeado em um acidente com radiação gama. Pensando nos raios gama, isso de fato poderia acontecer? Justifique.

\footnotetext{
${ }^{2}$ Ano-luz: distância que a luz percorre em 1 ano; 1 ano-luz $=9,5 \cdot 10^{15} \mathrm{~m}$.
} 


\section{Texto Suplementar: Vendo através da pele: a descoberta dos Raios $\mathbf{X}^{1}$}

Há pouco mais de 100 anos atrás, não era possível o médico visualizar o interior do corpo humano sem ter que abrí-lo e isso dificultava muito o diagnostico de doenças e fraturas nos pacientes. Mas em 1895 uma grande descoberta revolucionou a humanidade, principalmente a física e a medicina, nesse ano eram descobertos os raios $\mathbf{X}$. Mas como isso ocorreu?

Na noite de 8 de novembro de 1895 o físico holandês Wilhelm Conrad Röntgen (1845-1923), seguindo as tendências de sua época, estava fazendo mais uma experiência com descargas elétricas nos tubos de raios catódicos (figura 1), estudando o fenômeno da luminescência produzida pelos raios no tubo. Quando

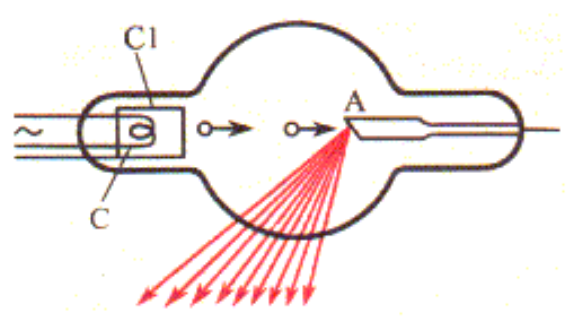

Figura 1 notou que algo de diferente acontecia. Em sua sala de experiências totalmente às escuras, ele viu a folha de papel, usada como tela e tratada com uma substância química fluorescente (platinocianeto de bário), colocada a uma certa distância do tubo brilhar emitindo luz.Röntgen espantado, pode imaginar que alguma coisa devia ter atingido a tela para que ela reagisse dessa forma. Mas o tubo de raios catódicos estava coberto por uma cartolina negra e nenhuma luz ou nenhum raio catódico poderia ter escapado dali.

Surpreso e perplexo com o fenômeno, ele decidiu pesquisá-lo mais a fundo. Virou a tela, de modo a que o lado sem a substância fluorescente ficasse voltado para o tubo; mesmo assim, a tela continuava a brilhar. Ele então afastou a tela para mais longe e o brilho persistiu. Depois, colocou diversos objetos (uma camada de papelão, pedaços de madeira, um livro de 1000 páginas e até finas placas metálicas) entre o tubo e a tela e todos pareceram transparentes. Quando sua mão escorregou em frente à válvula ele viu os ossos na tela (figura 2). Descobrira "um novo tipo de raio", conforme ele mesmo explicou em sua primeira publicação.

Röntgen havia ficado tão perplexo com sua descoberta, que teve que se convencer primeiro antes de falar com qualquer pessoa sobre sua descoberta do novo tipo de raio. Trabalhou sozinho durante sete semanas nessa tentativa, quando finalmente estava convencido, registrou sua descoberta (imagem da mão) em chapas fotográficas, e só então passou a ter certeza.

Em $1^{\circ}$ de janeiro de 1896, ele distribui o relatório preliminar de sua descoberta, o que causou grande agitação, mas sua descoberta

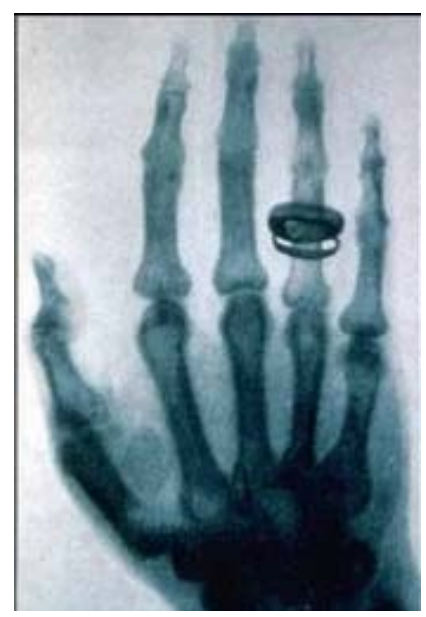

Figura 2 não podia ser refutada facilmente, pois havia fotografias dos raios $X$ de suas mãos anexadas nele. No decorrer do mês, a notícia havia se espalhado por todo o mundo. Pode-se imaginar o deslumbramento em relação a esses raios aos quais tudo se tornava transparente e por meio dos quais todos podiam ver seus próprios ossos. Pode-se ver praticamente os dedos sem os músculos, mas com anéis, como se podia ver também uma bala alojada no corpo. As conseqüências para a medicina foram imediatamente percebidas. Imagine você nessa época,

\footnotetext{
${ }^{1}$ Texto original do trabalho de mestrado de Maxwell Roger Siqueira.
} 
podendo ver os seus ossos, sem qualquer corte ou perfuração. Somente assim terá idéia da revolução causada com essa descoberta.

$\mathrm{O}$ trabalho de Röntgen sobre os raios $\mathrm{X}$ foi perfeito à luz do conhecimento existente em sua época. Mas ele, não conseguiu entender a natureza dos raios $X$, ou seja, ele não conseguiu comprovar que se tratava de uma radiação eletromagnética. No entanto, ele conseguiu mostrar que os raios podiam atravessar materiais sólidos, podiam ionizar o ar, não sofriam reflexão no vidro e não eram desviados por campos magnéticos, mas não conseguiu observar os fenômenos da refração e da interferência normalmente associados a ondas (ondas eletromagnéticas, neste caso) por isso ficou o nome enigmático de raios X ( $X$ é o símbolo pra nomear o desconhecido)

Mais tarde sua natureza foi desvendada, mostrando que eles eram conseqüência da colisão dos raios catódicos com a parede do tubo e, por terem comprimento de onda muito pequeno, Röntgen não podia observar os fenômenos necessários para comprovar que os raios-X são ondas eletromagnéticas (radiação eletromagnética) de alta freqüência.

Uma ilustração do equipamento de Röntgen é mostrado ao lado. Entre os catodos do tubo de vidro, os raios catódicos são inicialmente acelerados, com voltagem de até $100 \mathrm{KV}(100.000$ V) e, em seguida, são bruscamente freados (há uma colisão dos raios e o alvo). Por causa disso, ocorre uma emissão de radiação eletromagnética com um comprimento de onda muito pequeno (da ordem de $10^{-12} \mathrm{~m}$ ), que corresponde a radiações de

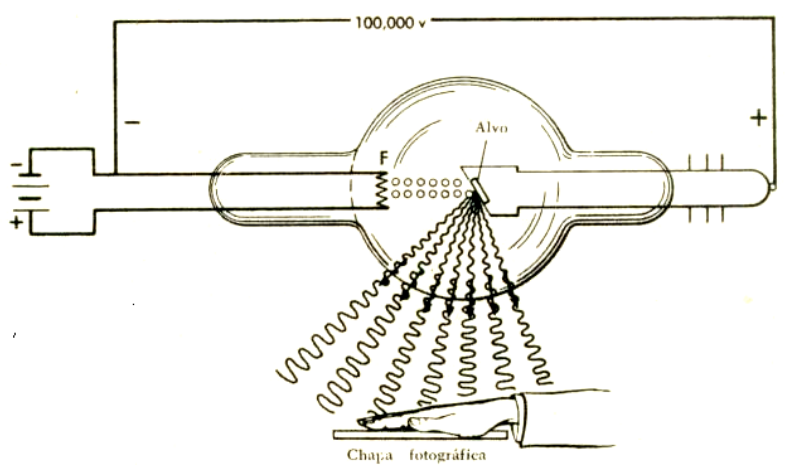
alta freqüência. É assim que são produzidos os raios $X$.

As aplicações dos raios $X$ são as mais diversas possíveis. Elas vão desde "simples" obtenção de chapas fotográficas (radiografias) para detectar uma fratura, uma inflamação e uma cárie até a determinação de uma certa porcentagem de uma substância em um composto, através da difração dos raios $\mathrm{X}$, como é o caso da quantidade de carbono existente no aço. Essa determinação é importante, pois permite que o aço fique mais maleável e conseqüentemente consegue-se produzir chapas mais finas.

Atualmente, os raios $X$ também são utilizados na área de segurança, como é o caso dos aeroportos. Com eles, é possível "ver" dentro das malas e constatar se existem objetos metálicos e até mesmo se as pessoas carregam algum tipo de arma (figura 3). Sua utilização também pode ser vista na fronteira dos E.U.A com o México, onde a polícia o utiliza para vasculhar o interior dos veículos (figura 4).

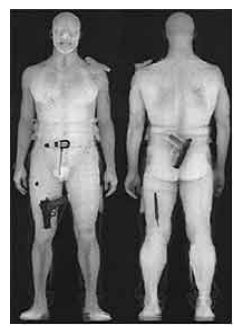

Figura 3

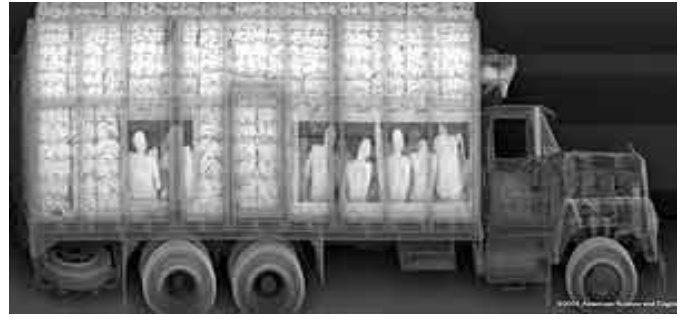

Figura 4 


\section{Questões}

1-) Nas radiografias, os contornos dos ossos aparecem bastante claros, sobre o fundo escuro, bem como 0 contorno de objetos e pessoas (Fig. 3 e 4). Analisando o processo de absorção dos raios X, estas regiões mais claras, recebem mais ou menos raios $X$ do que as outras? Explique sua resposta.

2-) Que semelhanças e diferenças têm os raios X e a luz visível?

3-) Como você imagina os diagnósticos médicos se os raios $X$ não tivessem sido descobertos? $O$ que os médicos fariam para perceber se você tem uma infecção ou um osso rachado? 


\section{Atividade 1 - Questionário Inicial}

Objetivo: Estimular a discussão sobre a Física das Radiações

Esta atividade tem o intuito de desafiar seus conhecimentos e concepções acerca dos fundamentos da Física das Radiações. O questionário traz afirmações que você pode concordar (sim), pode discordar (não) ou pode não saber nada sobre a afirmação (não sei) e está desenhado para despertar o seu interesse em aprender mais sobre este campo.

Não temos preocupação em testar os seus conhecimentos sobre o assunto. Queremos fazer somente um levantamento do que é conhecido por você no início e no final do curso.

Nome:

Série:

Turma:

Data:

\begin{tabular}{|l|l|l|l|}
\hline \multicolumn{1}{|c|}{ Afirmações } & Sim & Não & $\begin{array}{c}\text { Não } \\
\text { Sei }\end{array}$ \\
\hline $\begin{array}{l}\text { 1. Uma onda eletromagnética transporta energia através } \\
\text { de um meio material. }\end{array}$ & & \\
\hline $\begin{array}{l}\text { 2. As radiações podem ser classificadas como radiações } \\
\text { corpusculares e radiações eletromagnéticas. }\end{array}$ & & \\
\hline
\end{tabular}

3. Podemos organizar a radiação em dois grupos: a radiação corpuscular e a radiação eletromagnética.

4. Raios $X$ e raios gama são exemplos de radiação eletromagnética.

5. Partículas alfa e partículas beta são exemplos de radiação corpuscular.

6. A luz é uma onda eletromagnética formada de partículas sem massa de repouso e sem carga, chamadas de fótons.

7. Os menores componentes do núcleo de um átomo são os prótons e os elétrons.

8. Os raios $X$ podem ser gerados quando elétrons colidem com um alvo metálico e são desacelerados.

9. A tela da televisão, assim como o Sol, emitem radiação eletromagnética.

10. Partículas alfa e beta são radiações corpusculares emitidas pelo núcleo do átomo.

11. As microondas geradas por um aparelho de microondas afetam preferencialmente materiais que contenham moléculas de água.

12. Materiais radioativos emitem radiação, pois apresentam seus núcleos instáveis.

13. Os raios gama são os raios mais energéticos que existem no espectro eletromagnético.

14. A radiação infravermelha pode ser detectada pela nossa pele, mas não pelos nossos olhos.

15. O Sol emite grande quantidade de raios ultravioleta que são em boa parte, filtrados pela camada de ozônio. 
Física das Radiações: Uma Proposta para o Ensino Médio

16. Os raios gama são muito utilizados em Medicina no tratamento de câncer.

17. O Brasil já tem em sua história o registro de acidentes radioativos.

18. O Brasil possui usinas nucleares em funcionamento e que são responsáveis pela geração de eletricidade.

19. As radiações podem ser empregadas na medicina diagnóstica. 


\section{Atividade 2 - Análise da Chama de uma Vela}

Objetivo: Analisar a chama de uma vela e identificar as suas diferentes regiões.

Esta atividade introduz o estudo das ondas eletromagnéticas à partir da identificação das diferentes colorações presentes na chama de uma vela.

Para esta atividade os alunos deverão formar grupos com 4 integrantes e formularem sínteses das discussões, baseando-se nas orientações abaixo.

\section{$\underline{\text { Material }}$}

- Vela.

- Papel Sulfite A4.

- Lápis de cor.

\section{Orientaç̃es}

1-) Acender a vela e procurar representar com lápis de cor em um papel, as diferentes colorações que nela apareçam.

2-) Discutir com os colegas do grupo se existe alguma relação entre a cor de cada região, temperatura e energia. Para facilitar este processo pode-se montar uma tabela como a do modelo abaixo, onde pode-se estimar a temperatura e a energia em baixa, média ou alta, conforme a cor identificada.

\begin{tabular}{|c|c|c|}
\hline $\begin{array}{c}\text { Cor da chama } \\
\text { identificada }\end{array}$ & Temperatura & Energia \\
\hline & & \\
\hline & & \\
\hline & & \\
\hline
\end{tabular}

3-) A partir disso, tentar estabelecer em que parte da vela temos maior energia e a menor energia.

4-) Escrever uma pequena conclusão referente aos resultados obtidos. 


\section{Atividade 3 - Transmissor de Ondas Eletromagnéticas}

Objetivo: Realizar a montagem de um transmissor de ondas eletromagnéticas, explorando a forma de geração da onda.

Esta atividade explora a geração de uma onda eletromagnética que pode ser detectada facilmente em um rádio do tipo AM.

Para esta atividade os alunos deverão formar grupos com 4 integrantes e formularem sínteses das discussões, baseando-se nas orientações abaixo.

\section{Materiais:}

- Pedaço de fio metálico.

- Pilha grande.

- Rádio AM.

\section{Orientações}

1-) Ligar o rádio AM é sintonizar em uma freqüência não usada.

2-) Pegar um pedaço de fio metálico e ligá-lo a uma pilha, fazendo isso próximo ao rádio, conforme o esquema abaixo.

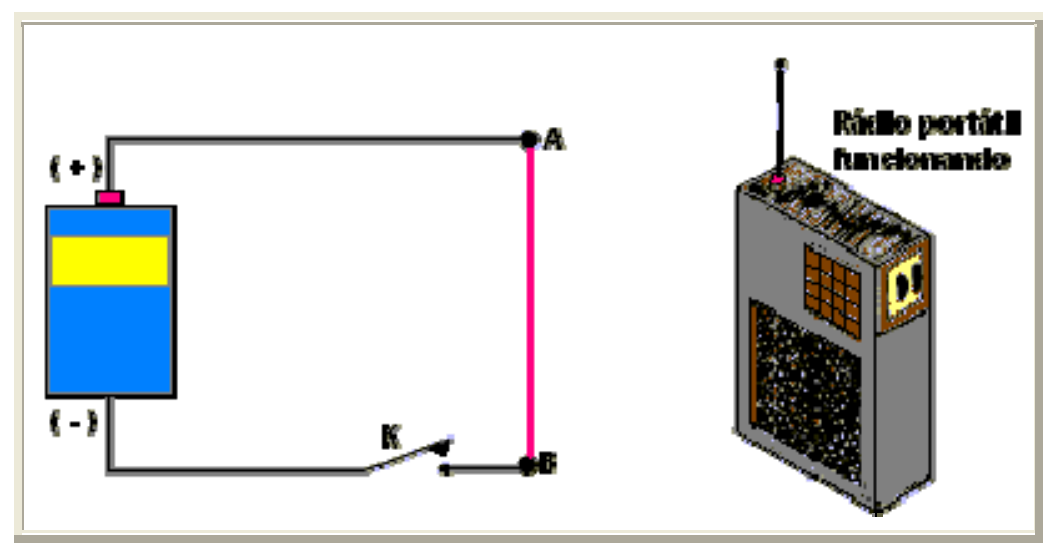

3-) Perceber o que acontece no rádio quando o fio é ligado à pilha.

4-) Escrever uma pequena conclusão referente aos resultados obtidos. 
Física das Radiações: Uma Proposta para o Ensino Médio

\section{Atividade 4 - Dispersão da Luz}

Objetivo: Realizar com o auxílio de um prisma ou CD, a dispersão da luz branca de uma lâmpada incandescente ou fluorescente.

Esta atividade explora a dispersão da luz branca de uma lâmpada incandescente ou fluorescente em seu espectro.

Para esta atividade os alunos deverão formar grupos com 4 integrantes e formularem sínteses das discussões, baseando-se nas orientações abaixo.

\section{Materiais:}

- Lâmpada incandescente ou lâmpada fluorescente.

- Prisma ou CD.

- Lápis de cor.

\section{Orientações}

1-) Aponte o prisma ou CD para a luz da lâmpada e veja o que aparece.

2-) Desenhe em uma folha de papel, usando lápis de cor, o que você observou.

3-) O que te lembra a figura que você observou?

4-) Discuta em grupo e elabore uma resposta que justifique o que aconteceu.

5-) Caso você apontasse o prisma ou CD para a luz do Sol, o que você acha que iria encontrar? Por quê?

6-) Escrever uma pequena conclusão referente aos resultados obtidos. 
Física das Radiações: Uma Proposta para o Ensino Médio

\section{Atividade 5 - Analisando Radiografias}

Objetivo: Estimular a discussão sobre os raios X, sua produção e a produção das radiografias.

Esta atividade servirá para introdução ao estudo dos raios $X$, sendo uma atividade que provavelmente já tenha desafiado a curiosidade de alguns.

Formem grupos com 4 alunos e formule sínteses das discussões, baseando-se nas orientações abaixo.

\section{Materiais:}

- Radiografias diversas.

\section{Orientações}

1-) Discuta com seus colegas, como se realiza um exame de raios X: Quanto tempo demora a realização do exame? Como é a sala em que fica o equipamento? É necessário tirar a roupa, ao se fazer um exame de raios $X$ ? Há algum barulho característico, ao se realizar o exame? Alguém acompanha o paciente, durante o exame, na mesma sala? Como são as paredes da sala? etc.

2-) Observe as radiografias apresentadas por seu professor e identifique as partes do corpo correspondentes às regiões claras e escuras nas radiografias, as doenças, as fraturas, os cistos, o membro radiografado, se há algum corpo estranho, a faixa cronológica da pessoa radiografada, o sexo, etc. 


\section{Física das Radiações: Uma Proposta para o Ensino Médio}

\section{Atividade extra - Grade do Microondas}

Objetivo: Verificar a existência de uma grade na porta do microondas.

Esta atividade explora a necessidade da grade na porta doas parelhos de microondas.

Para esta atividade os alunos deverão formar grupos com 4 integrantes e formularem sínteses das discussões, baseando-se nas orientações abaixo.

\section{Materiais:}

- Foto da grade da porta de um aparelho de microondas.

\section{Orientações}

1-) Observar a foto abaixo. Ela mostra a grade que encontramos na porta de todo aparelho de microondas.

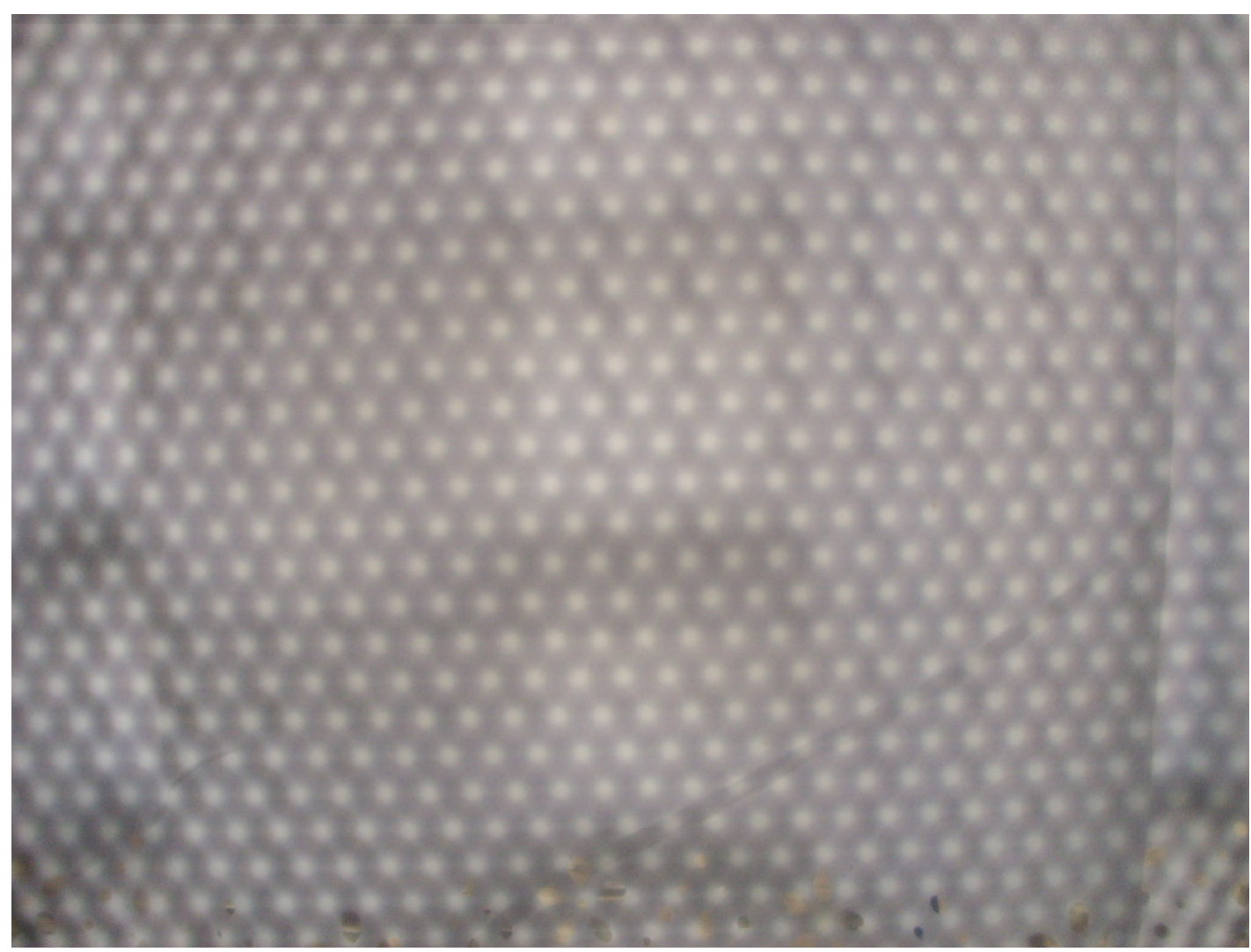

2-) Discutir em grupo a razão desta grade existir na porta do aparelho.

3-) Seria possível estimar o tamanho dos furos nesta grade? Como?

4-) Escrever uma pequena conclusão referente aos resultados obtidos. 


\section{Atividade extra - Receptor de Ondas Eletromagnéticas}

Objetivo: Realizar a montagem de um rádio de galena e verificar a captação de ondas de rádio.

Esta atividade explora a montagem de um rádio de galena que é um rádio simples, que utiliza poucos componentes, mas que permite a captação de ondas de rádio na faixa do $\mathrm{AM}$.

Para esta atividade os alunos deverão formar grupos com 4 integrantes e formularem sínteses das discussões, baseando-se nas orientações abaixo.

\section{Materiais:}

- 20 metros de fio de cobre (esmaltado), número 24.

- 20 metros de fio de cobre (tipo cabinho), número 22.

- Tubo de PVC de 2,5 a $3 \mathrm{~cm}$.

- 1 capacitor de 78 pF.

- 1 diodo de germânio modelo 1N34.

- 1 fone de cristal.

\section{Orientações}

1-) Primeiramente deve-se seguir os passos abaixo para confecção do rádio.

a) Os elementos necessários para a montagem de um rádio galena (seguindo o circuito da figura anterior) são simples e fáceis de serem encontrados nas lojas especializadas. São basicamente os seguintes:

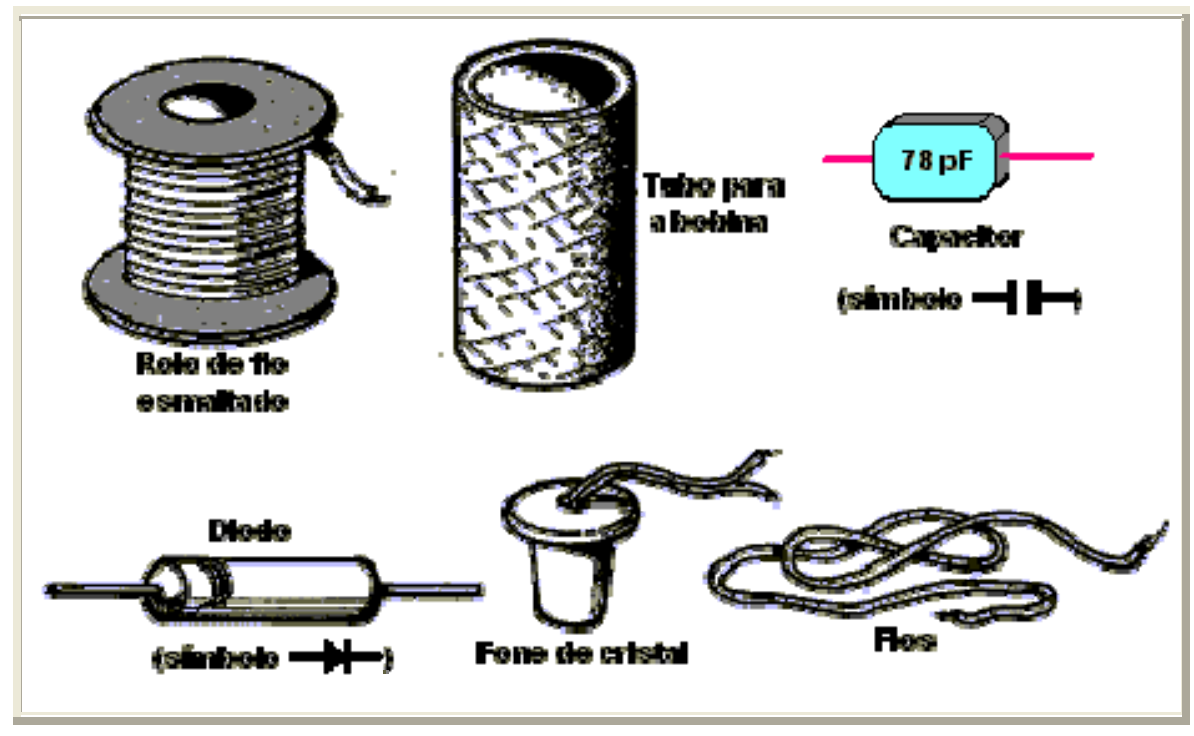

a1. Fio de cobre esmaltado para o enrolamento da bobina. Vamos precisar de 20 metros de fio \# 24 (lojas de enrolamentos e consertos de motores); 
a2. Um tubo de PVC, ou mesmo, de papelão duro, para enrolar a bobina. Para se ter uma idéia grosseira desse tubo, basta dizer, que é possível substituí-lo pelo tubo de papelão no qual vem enrolando o papel higiênico. Esse tubo de material bom isolante elétrico tem comprimento de 10 a $12 \mathrm{~cm}$ e diâmetro entre 2,5 e $3,0 \mathrm{~cm}$.

a3. Um capacitor fixo. Seu valor é algo como 78 pF (leia 78 picofarad), disco ou cerâmico.

a4. Um diodo de germânio para RF. Serve o tipo OA-90 ou equivalente (1N34 etc.)

a5. Um fone de ouvido (cristal). Obtido de antigos rádios à pilha (os atuais fones de 8 ohms não servem!).

a6. Fios longos para serem usados como antena e como "Fio-terra". Uns 20 metros de cabinho \# 22 devem ser suficientes.

b) É claro, necessitamos das especificações técnicas de cada um destes elementos, pois do contrário, nenhuma loja poderá nos fornecer o material adequado. Damos estas especificações, acima, junto com a lista dos materiais. É possível que você não entenda exatamente o que elas significam; mas, pode estar certo de que, o homem da loja, ao ler a especificação, saberá, com exatidão, o que está sendo pedido.

c) Em linhas gerais, a montagem de um rádio galena pode ser resumida nos itens abaixo.

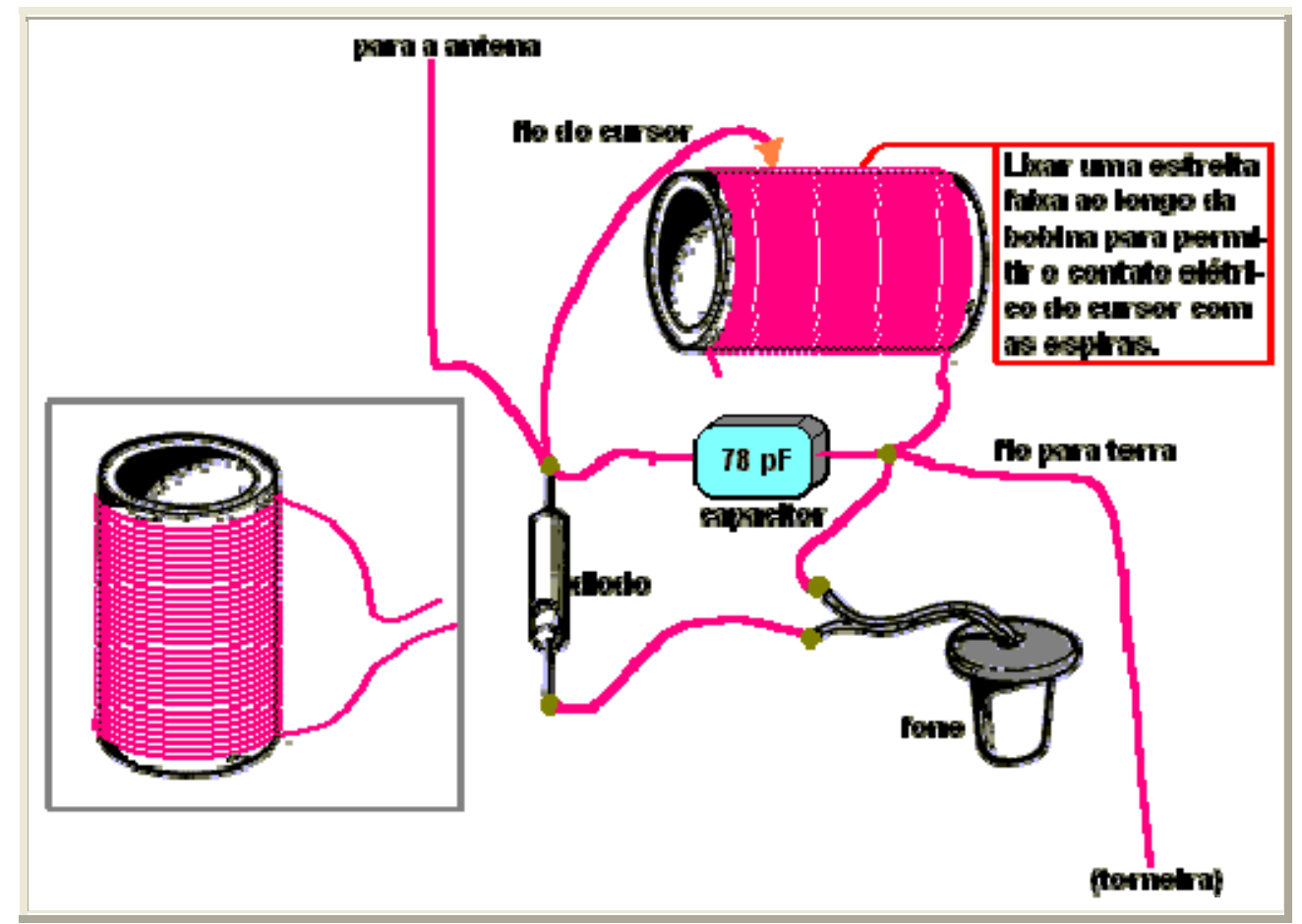

c1. Enrolar o fio esmaltado \#24, no tubo, para obter uma bobina com núcleo de ar. Deixar $15 \mathrm{~cm}$ livre em cada extremidade e lixar essas extremidades para retirar o esmalte protetor (detalhe acima à esquerda).

c2. A seguir, os diferentes elementos deverão ser ligados como mostra a figura acima. Seu professor poderá auxiliá-lo nessa etapa. 
2-) Após a montagem, testar o rádio ligando o fio terra a torneira o que facilita a captação das ondas de rádio.

3-) Tentar ouvir alguma captação de onda através do fone.

4-) Pesquisar em casa e trazer na próxima aula o funcionamento dos seguintes componentes do rádio: a bobina, o diodo e o capacitor. De posse dessas informações, tente explicar o funcionamento do rádio de Galena.

5-) Escrever um pequeno relatório referente aos resultados obtidos. 


\section{Atividade extra - Vendo o Infravermelho}

Objetivo: Observar o aquecimento de um ferro de passar elétrico e verificar o tipo de radiação emitida por ele.

Esta atividade explora o aquecimento de um ferro de passar elétrico e tenta trazer para a discussão a forma de radiação presente nesta situação.

Para esta atividade os alunos deverão formar grupos com 4 integrantes e formularem sínteses das discussões, baseando-se nas orientações abaixo.

\section{Materiais:}

- Ferro de passar elétrico.

\section{Orientações}

1-) Em uma sala escura, ligar um ferro de passar elétrico e observar o aquecimento de sua base de metal.

2-) Para cada temperatura, registrar a observação em uma tabela semelhante a seguinte:

\begin{tabular}{|l|l|}
\hline $\begin{array}{c}\text { Temperatura ajustada para o } \\
\text { ferro elétrico }\end{array}$ & $\begin{array}{c}\text { Observação feita quando a cor } \\
\text { da base de metal do ferro elétrico }\end{array}$ \\
\hline & \\
\hline & \\
\hline & \\
\hline
\end{tabular}

3-) Em grupo, discutir para qual temperatura ajustada foi possível observar algum efeito.

4-) É possível dizer que tipo de radiação está presente neste caso?

5-) Escrever uma pequena conclusão referente aos resultados obtidos. 


\section{Atividade extra - Teste de Daltonismo}

Objetivo: Realizar o teste de daltonismo e verificar se a pessoa apresenta este problema genético.

Esta atividade explora o uso de imagens em um teste conhecido como teste de Ishihara para identificar o daltonismo em uma pessoa.

Para esta atividade os alunos deverão formar grupos com 4 integrantes e formularem sínteses das discussões, baseando-se nas orientações abaixo.

\section{Materiais:}

- Imagens (teste de Ishihara).

\section{Orientações}

1-) Você é daltônico? Não sabe? Para detectar o daltonismo, usa-se o teste de Ishihara, em que pontilhados coloridos formam determinados números ou letras. $\mathrm{Na}$ figura abaixo, existe um número. Que número é este? Uma pessoa normal consegue enxergá-lo sem maiores problemas!

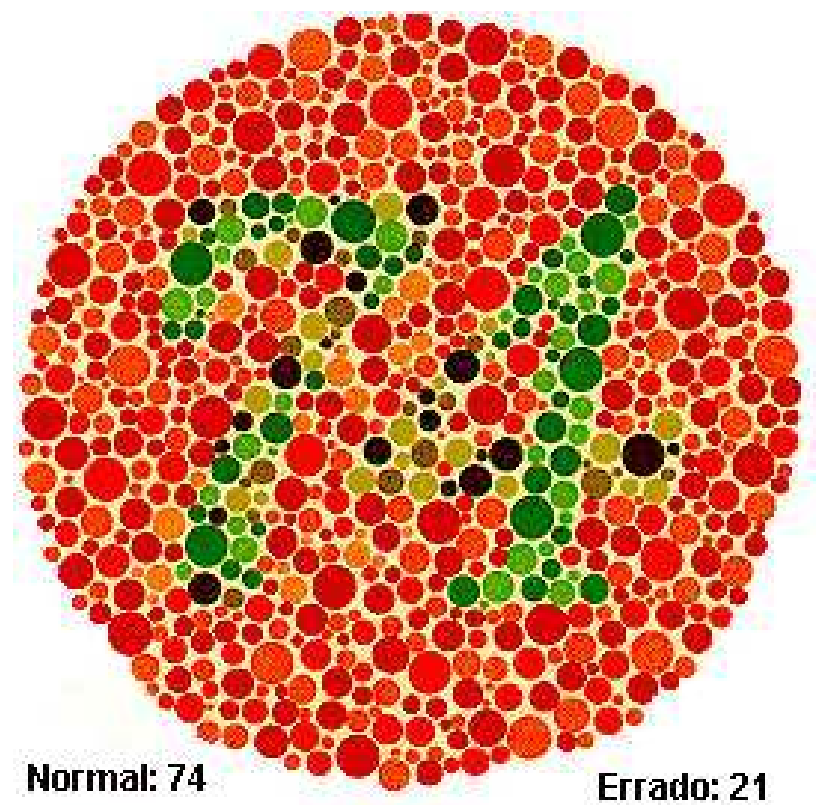




\section{QUADRO SINTÉTICO}

\section{Bloco 2 - Radiações Corpusculares}

\begin{tabular}{|c|c|c|c|}
\hline \multirow{7}{*}{ 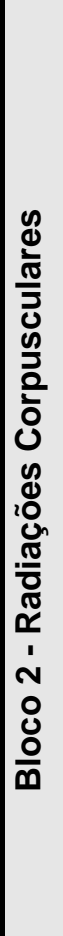 } & ATIVIDADE(S) & MOMENTOS & TEMPO \\
\hline & $\begin{array}{l}\text { 7. Visualizando o átomo e a sua } \\
\text { estrutura. }\end{array}$ & $\begin{array}{l}\begin{array}{l}\text { Atividade } 6 \text { - Cortando papel para chegar ao } \\
\text { próton e as dimensões dos corpos em potência de } \\
\text { dez. (25 min) }\end{array} \\
\begin{array}{l}\text { Explicações sobre representações de dimensões } \\
\text { em potência de dez. (25 min) }\end{array} \\
\begin{array}{l}\text { Sistematização, leitura e resposta às questões do } \\
\text { texto: "Caracterizando o Átomo". (40 min) }\end{array} \\
\end{array}$ & 2 AULAS \\
\hline & \multirow[b]{2}{*}{ 8. Estabilidade Nuclear. } & $\begin{array}{l}\text { Atividade } 7 \text { - A Tabela Periódica e seus } \\
\text { elementos radioativos. (20 min) }\end{array}$ & \multirow[b]{2}{*}{1 AULA } \\
\hline & & $\begin{array}{l}\text { Discussão sobre a estabilidade nuclear. (10 min) } \\
\text { Sistematização, leitura e respostas às perguntas } \\
\text { do texto "A interação Nuclear e a Estabilidade do } \\
\text { Núcleo". (15 min) }\end{array}$ & \\
\hline & \multirow{3}{*}{$\begin{array}{l}\text { 9. Vídeo: "A descoberta da } \\
\text { radioatividade" e visão panorâmica } \\
\text { do conteúdo trabalhado. }\end{array}$} & \begin{tabular}{|l|} 
Vídeo: "A descoberta da radioatividade". (10 min) \\
$\begin{array}{l}\text { Discussão sobre os tipos de decaimentos } \\
\text { radioativos. ( } 20 \mathrm{~min})\end{array}$ \\
\end{tabular} & \multirow{3}{*}{2 AULAS } \\
\hline & & $\begin{array}{l}\text { Sistematização e respostas às perguntas do texto } \\
\text { "Compreendendo os Decaimentos Radioativos". } \\
(15 \mathrm{~min})\end{array}$ & \\
\hline & & Avaliação referente ao bloco 2. (45 min) & \\
\hline
\end{tabular}




\section{BLOCO 2 - RADIAÇÕES CORPUSCULARES}

Após conhecermos as radiações eletromagnéticas, iniciamos agora o estudo e compreensão das radiações corpusculares, isto é, das radiações constituídas por partículas elementares. Para isso falaremos sobre a estrutura do átomo, a interação forte que ocorre no núcleo atômico e do fenômeno da Radioatividade.

\section{Objetivos gerais:}

$\checkmark$ Estimular a curiosidade para o estudo das radiações corpusculares.

$\checkmark$ Conhecer e compreender a estrutura do átomo.

$\checkmark$ Compreender a interação nuclear e a estabilidade do núcleo.

$\checkmark$ Entender a natureza das radiações emitidas por elementos radioativos e os decaimentos radioativos.

\section{Conteúdo Físico}

$\checkmark$ Radiações corpusculares.

$\checkmark$ Estrutura do átomo.

$\checkmark$ Interação nuclear forte.

$\checkmark$ Radioatividade.

\section{Leitura complementar}

As leituras indicadas servem para um conhecimento mais profundo e detalhado dos conceitos tratados neste bloco. Assim, caso seja possível, leia algumas dessas referências antes de iniciar as aulas.

$\checkmark$ ALVARENGA, Beatriz; MÁXIMO, Antônio. Física. $2^{\mathrm{a}}$ ed., $1^{\mathrm{a}}$ impressão, São Paulo: Editora Scipione, 2007.

$\checkmark$ CARUSO, Francisco; SANTORO, Alberto. Do átomo Grego à Física das interações fundamentais. $2^{\mathrm{a}}$ ed. Rio de Janeiro: AIAFEX, 2000.

$\checkmark$ GASPAR, Alberto. Eletromagnetismo e Física Moderna. $1^{\mathrm{a}}$ ed., $2^{\mathrm{a}}$ impressão, São Paulo: Editora Ática, 2001.

$\checkmark$ HEWITT, Paul. Física Conceitual. 9a ed. Porto Alegre: Bookman, 2002.

$\checkmark$ SEGRÉ, E. Dos raios X aos Quarks. Físicos Modernos e suas Descobertas. Universidade de Brasília, Brasília, 1982.

$\checkmark$ SERWAY, Raymound A.; JEWETT, John W. Princípios de Física: Óptica e Física Moderna. $3^{\mathrm{a}}$ ed. Rio de Janeiro: Thomson, 2005.

$\checkmark \quad$ TIPLER, Paul A.; LLEWELLYN, Ralph A. Física Moderna. $3^{a}$ ed. Rio de Janeiro: LTC, 2001. 


\section{Quadro Sintético}

\begin{tabular}{|c|c|c|c|}
\hline ATIVIDADES & MOMENTOS & COMENTÁRIOS & Tempo \\
\hline \multirow{3}{*}{$\begin{array}{l}\text { 1. Visualizando o } \\
\text { átomo e a sua } \\
\text { estrutura. }\end{array}$} & $\begin{array}{l}\text { Atividade } 6 \text { - Cortando papel para } \\
\text { chegar ao próton e as dimensões dos } \\
\text { corpos em potência de dez. }\end{array}$ & 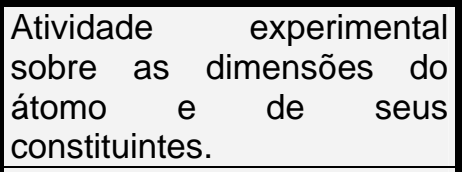 & \multirow{3}{*}{2 aulas } \\
\hline & $\begin{array}{l}\text { Explicações sobre representações de } \\
\text { dimensões em potência de dez. }\end{array}$ & $\begin{array}{l}\text { Navegação no site do } \\
\text { CERN (Powers of Ten). }\end{array}$ & \\
\hline & $\begin{array}{l}\text { Leitura e sistematização geral sobre } \\
\text { ordem de grandeza e notação científica. }\end{array}$ & $\begin{array}{l}\text { Texto: "Caracterizando o } \\
\text { Átomo". }\end{array}$ & \\
\hline \multirow[t]{2}{*}{$\begin{array}{l}\text { 2. Estabilidade } \\
\text { Nuclear. }\end{array}$} & $\begin{array}{l}\text { Atividade } 7 \text { - A Tabela Periódica e seus } \\
\text { elementos radioativos. }\end{array}$ & $\begin{array}{l}\text { Atividade } \\
\text { Tabela o uso da } \\
\text { Tabela Periódica para } \\
\text { identificação dos elementos } \\
\text { radioativos. }\end{array}$ & \multirow[t]{2}{*}{1 aula } \\
\hline & $\begin{array}{l}\text { Sistematização, leitura e respostas às } \\
\text { perguntas do texto. }\end{array}$ & $\begin{array}{l}\text { Texto: "A interação Nuclear } \\
\text { e a Estabilidade do Núcleo". }\end{array}$ & \\
\hline \multirow[t]{2}{*}{$\begin{array}{l}\text { 3. Vídeo: "A } \\
\text { descoberta da } \\
\text { radioatividade". }\end{array}$} & Vídeo: "A descoberta da radioatividade". & $\begin{array}{l}\text { Fornece a construção } \\
\text { histórica dos trabalhos que } \\
\text { levaram até a descoberta } \\
\text { da Radioatividade. }\end{array}$ & \multirow[t]{2}{*}{1 aula } \\
\hline & $\begin{array}{l}\text { Sistematização, leitura e respostas às } \\
\text { perguntas do texto. }\end{array}$ & $\begin{array}{l}\text { Texto: "Compreendendo os } \\
\text { Decaimentos Radioativos". }\end{array}$ & \\
\hline 4. Avaliação. & $\begin{array}{l}\text { Aplicação de uma avaliação sobre o } \\
\text { conteúdo trabalhado no bloco } 2 \text {. }\end{array}$ & & 1 aula \\
\hline
\end{tabular}




\section{Descrição aula-a-aula}

\section{AULA 9}

Tema: Notação científica, ordem de grandeza e dimensões do mundo microscópico.

Objetivo: Trabalhar de forma mais detalhada com os alunos, as dimensões do mundo microscópico, que é o objeto de estudo da proposta. Fazer com que eles tenham uma idéia inicial do "mundo de pequenas dimensões" do átomo e suas partículas.

Trabalhar matematicamente com alguns números e grandezas usando a notação científica e a definição de ordem de grandeza.

Conteúdo Físico: Dimensões do mundo microscópico (do átomo), ordem de grandeza e notação científica.

\section{Recursos Instrucionais}

- Roteiro da atividade 6 (1 $1^{\text {a }}$ parte);

- Aula expositiva;

- Discussão entre professor e alunos;

- Folhas de papel A4, tesouras e réguas.

\section{Motivação}

Curiosidade sobre o tamanho limite que conseguimos enxergar.

\section{Momentos}

\begin{tabular}{|c|c|}
\hline \multirow[t]{2}{*}{ 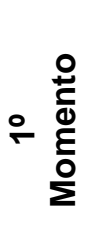 } & $\begin{array}{l}\text { Atividade } 6\left(1^{a} \text { parte): "Visualizando o muito pequeno"' - cortando papel para chegar a }\right. \\
\text { prótons. Essa atividade pode ser realizada em grupo. Alguns grupos podem utilizar } \\
\text { tesouras para cortar o papel enquanto outros podem usar réguas conforme o roteiro. } \\
\text { Destacar o número de cortes feitos por cada grupo e as medidas do menor pedaço de } \\
\text { papel obtido. }\end{array}$ \\
\hline & Tempo: $\pm 25 \mathrm{~min}$ \\
\hline
\end{tabular}

\begin{tabular}{|c|c|}
\hline \multirow[t]{2}{*}{ 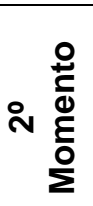 } & $\begin{array}{l}\text { Leitura do texto: "Ordem de grandeza e potência de dez", e após explicação sobre o } \\
\text { que é ordem de grandeza e notação científica e a utilização da potência de dez em } \\
\text { ambos os casos, os alunos podem, em grupo, começar a discutir e resolver os } \\
\text { exercícios propostos. }\end{array}$ \\
\hline & Tempo: $\pm 20 \mathrm{~min}$ \\
\hline
\end{tabular}

Sugestões: Se o professor achar necessário e caso tenha tempo disponível, pode trabalhar mais exercícios sobre notação científica e ordem de grandeza.

\section{Dinâmica da aula}

O professor deve inicialmente destacar que o universo das partículas que estamos adentrando é de dimensões muito pequenas. Destacando também a importância de trabalharmos numericamente com essas dimensões. Em seguida deve-se iniciar a $1^{\mathrm{a}}$ parte da atividade "Visualizando 'o muito pequeno'" pedindo para que formem grupos, cortem o papel e anotem os números de cortes feitos e a medida do menor pedaço obtido. Podem inclusive anotar na lousa os valores obtidos para o número de cortes e a menor medida obtida para comparação e discussão entre os grupos.

Após esta atividade o professor deve explicar a noção de ordem de grandeza e notação científica que serão extremamente úteis para a representação numérica já citada.

Os alunos recebem o roteiro e trabalham com os exercícios propostos. 


\section{AULA 10}

Tema: Notação científica, ordem de grandeza e dimensões do mundo microscópico.

Objetivo: Trabalhar com os alunos as dimensões do mundo microscópico, comparando com as dimensões com as quais eles estejam mais acostumados.

Conteúdo Físico: Dimensões do mundo microscópico do átomo.

\section{Recursos Instrucionais}

- Roteiro da atividade 6 ( $2^{\mathrm{a}}$ parte);

- Apresentação de slides;

- Aula expositiva;

- Discussão entre professor e aluno baseado nos textos: "Conhecendo as Radiações" e "Espectro Eletromagnético (Introdução)".

Motivação: Curiosidade sobre o tamanho do átomo e relação com o tamanho dos objetos que nos cercam.

\section{Momentos}
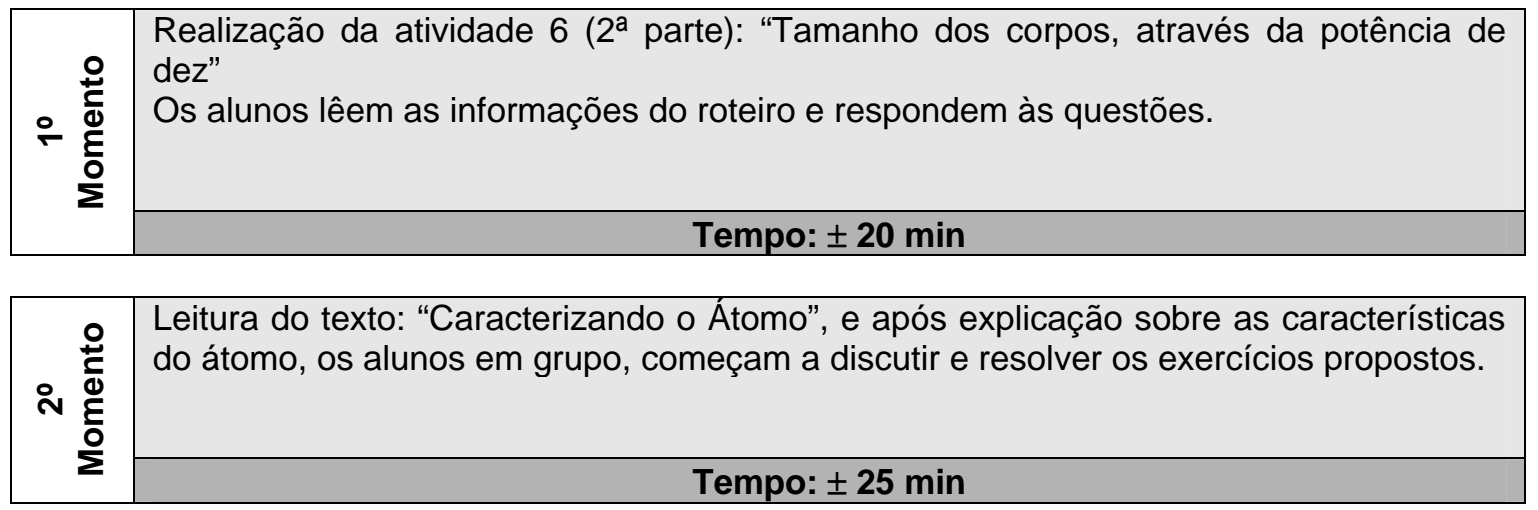

Sugestões: Se esta aula não for no mesmo dia da anterior, o professor deve relembrar rapidamente as atividades sobre notação científica e ordem de grandeza.

Caso o professor achar necessário e caso tenha tempo disponível, pode trabalhar mais exercícios sobre notação científica e potência de dez.

Se o professor não tiver como mostrar os slides através do site do CERN (powers of ten), pode preparar uma apresentação utilizando o power point ou ainda retro-projetor.

Se for utilizar a sala de informática, o professor já deve iniciar a aula nela para não perder tempo com a organização dos alunos.

Caso o professor queira valorizar a utilização da sala de informática, pode dividir a turma em duas partes. Enquanto uma dessas partes realiza a atividade do texto na sala de aula, os demais exploram o site do CERN na sala de informática.

\section{Dinâmica da aula}

Retomada da atividade "Ordem de grandeza e potência dez", na correção o professor deve destacar sempre as grandezas trabalhadas em relação às que estamos habituados.

Pedir para que os alunos leiam as instruções da atividade "Tamanho dos corpos através da potência de dez", e respondam com base nos slides, a questão. 


\section{AULA 11}

Tema: Estabilidade nuclear.

Objetivo: Possibilitar a compreensão da estabilidade do núcleo atômico.

Conteúdo Físico: Interação forte.

\section{Recursos Instrucionais:}

- Roteiro da atividade 7;

- Tabela Periódica;

- Aula expositiva;

- Discussão entre professor e aluno baseado nos textos: "A Interação Nuclear e a Estabilidade do Núcleo".

Motivação: Entender de maneira clara como se dá a estabilidade do núcleo atômico, embora ocorra a força de repulsão Coulombiana entre prótons.

\section{Momentos:}

\begin{tabular}{|r|l|}
\hline & $\begin{array}{l}\text { Propor a atividade 7: "A tabela periódica e seus elementos radioativos". O professor } \\
\text { fornece para cada aluno uma tabela periódica e pede para que os alunos procurem } \\
\text { identificar elementos que são radioativos. Os alunos podem se basear nas legendas }\end{array}$ \\
que a tabela periódica apresenta para identificarem os elementos radiativos. Os alunos \\
ainda podem identificar o número de massa, número atômico e número de nêutrons \\
dos elementos reconhecidos como radioativos, procurando alguma relação entre essas \\
informações e o fato do elemento ser radioativo.
\end{tabular}

\begin{tabular}{|c|c|}
\hline \multirow{2}{*}{ 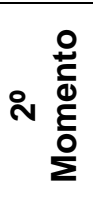 } & $\begin{array}{l}\text { Sistematização da atividade e discussão sobre as e estabilidade nuclear com base no } \\
\text { texto: "A Interação Nuclear e a Estabilidade do Núcleo". }\end{array}$ \\
\hline & Tempo: $\pm 25 \mathrm{~min}$ \\
\hline
\end{tabular}

Sugestão: O professor deve relembrar com os alunos as informações que caracterizam um átomo e seus significados, como o número de massa e número atômico. Em seguida, relembrar com os alunos como a tabela periódica está organizada (ordem crescente de número atômico) e pedir que eles sigam as legendas presentes na tabela para identificarem aqueles elementos que são radioativos, além daqueles elementos que os alunos já conhecem como tendo esta característica.

Dinâmica da Aula: Iniciar a discussão falando sobre o núcleo atômico, seus constituintes, o seu aspecto esférico e de dimensões da ordem de $10^{-15} \mathrm{~m}$. Questionar os alunos quanto à estabilidade do núcleo e como ela é possível, já que existem para átomos com dois ou mais prótons, a força de repulsão Coulombiana. Uma pergunta que poderia ser feita seria a seguinte: Por que o núcleo do átomo não se desfaz? Dar a oportunidade de os alunos responderem à questão e intermediar a discussão de forma que se possa introduzir a nova interação entre as partículas do núcleo, no caso, a interação forte. Relembrar o significado de número de massa e número atômico, e como se determina o número de nêutrons com essas informações. Mostrar que para um aumento do numero de prótons do núcleo deve haver um aumento do número de nêutrons para compensar a repulsão entre os prótons, até o limite onde a interação forte consegue manter a estabilidade nuclear que ocorre para elementos com número atômico até de 83 , pois após este número, os elementos já são radioativos. Finalmente, peça para que eles respondam às questões propostas no texto. 


\section{AULA 12}

Tema: Decaimentos radioativos.

Objetivo: Compreender os tipos de decaimentos radioativos e as leis que explicam esses decaimentos.

Conteúdo Físico: Emissões alfa, beta e gama.

\section{Recursos Instrucionais:}

- Vídeo: A Descoberta da radioatividade;

- Discussão entre professor e aluno baseado nos textos: "Compreendendo os Decaimentos Radioativos";

- Aula expositiva.

\section{Motivação:}

Momentos:

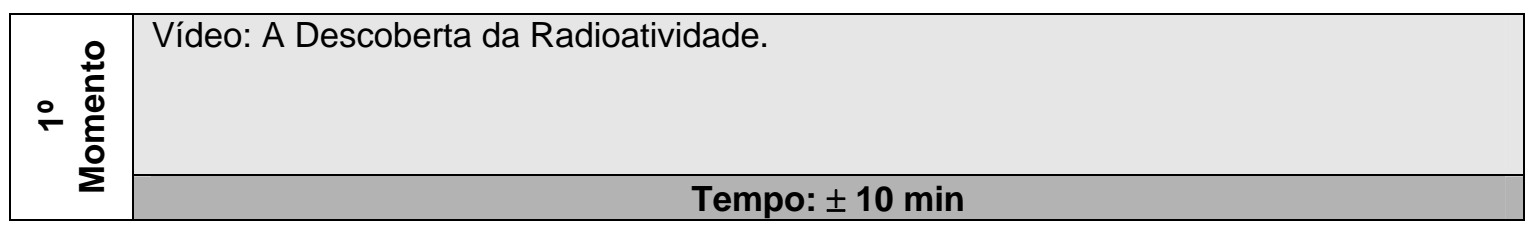

\begin{tabular}{|c|c|}
\hline \multirow[t]{2}{*}{ 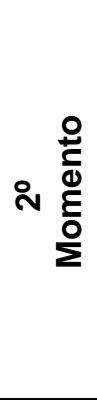 } & $\begin{array}{l}\text { Sistematizar as idéias apresentadas no vídeo, como por exemplo, a razão de alguns } \\
\text { elementos serem classificados de radioativos. Enfatizar os tipos de radiações } \\
\text { corpusculares que o núcleo atômico pode emitir. Apresentar a diferença das radiações } \\
\text { quanto ao poder de penetração, massa e carga elétrica, quando comparadas entre si. } \\
\text { Sistematização da discussão sobre os decaimentos radioativos com base no texto: } \\
\text { "Compreendendo os Decaimentos Radioativos". }\end{array}$ \\
\hline & Tempo: $\pm 35 \mathrm{~min}$ \\
\hline
\end{tabular}

Sugestão: O professor pode usar o texto suplementar: "A Descoberta da Radioatividade e das Radiações", caso não tenha como exibir o vídeo para introduzir o assunto. A apresentação do vídeo ajuda bastante na otimização do tempo da aula e na sistematização das idéias sobre o assunto.

Dinâmica da Aula: Inicia-se a aula com o vídeo sobre a descoberta da radioatividade. Em seguida faça uma sistematização das idéias apresentadas no vídeo. Assim é possível fazer uma discussão final, revisando os tipos de decaimentos radioativos e as leis que explicam essas emissões. O professor deve tomar o cuidado de diferenciar os tipos de radiação beta (beta mais e beta menos), apresentando as novas partículas participantes desses decaimentos, como o neutrino e o pósitron. Como o pósitron é a antipartícula do elétron, caso haja tempo, pode-se pedir uma pesquisa sobre as antipartículas conhecidas (que são muitas) e suas descobertas. 
AULA 13

Tema: Radiações corpusculares.

Objetivo: Verificação da aprendizagem.

Recursos Instrucionais:

- Avaliação escrita.

Momentos:

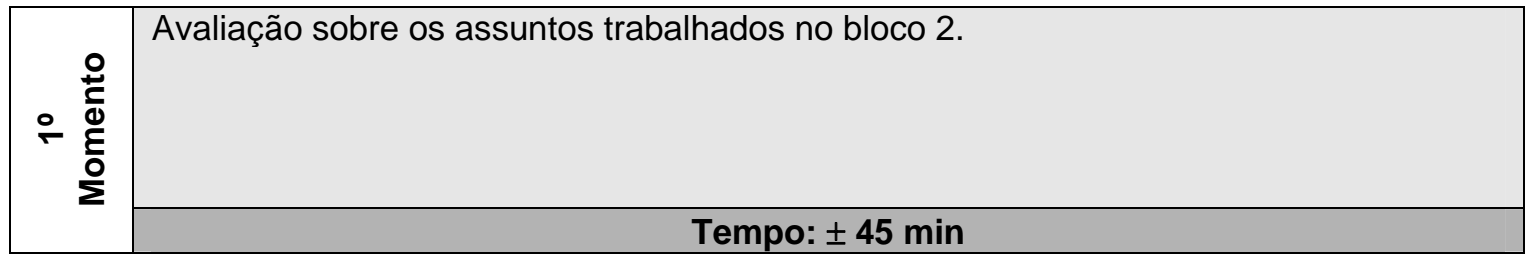

Observação: Caso o professor tenha a disponibilidade de duas aulas em seqüência pode iniciar a avaliação um pouco antes de terminar $14^{\mathrm{a}}$ aula disponibilizando mais tempo de resolução para os alunos.

Dinâmica da Aula: entrega das avaliações individuais sobre o bloco 2. 


\section{Radiações Corpusculares}

Certamente você já deve ter ouvido em algum momento da sua vida, termos como radioatividade, energia nuclear, bomba atômica, acidente nuclear, e outros termos que mais uma vez nos remetem as radiações e seus efeitos. Quase sempre esses termos são associados à destruição, dor e insegurança. Até hoje, quando mencionamos Guerra Fria, automaticamente pensamos em uma possível guerra nuclear que aconteceria entre as superpotências da década de 80, Estados Unidos e União Soviética, enquanto o restante do mundo ficava em desespero tentando imaginar o que poderia acontecer caso este fato se consumasse.

Em outros momentos da história já nos deparamos com as radiações e o seu emprego não tão benéfico. Podemos lembrar da Segunda Grande Guerra Mundial, onde o uso de bombas atômicas deixaram a humanidade em pânico com o enorme poder de destruição das bombas que foram jogadas pelos americanos sobre as cidades japonesas de Hiroshima e Nagasaki. Temos ainda, os acidentes que ocorreram em Goiânia (bomba de césio 137) e Chernobyl (explosão do reator nuclear), que trouxeram para os jornais e noticiários os perigos da chamada radiação.

Entretanto, o uso das radiações também trouxe melhorias e esperanças para muitas pessoas. Hoje o emprego das radiações é muito grande, como por exemplo, no tratamento do câncer, na geração de eletricidade, no diagnóstico de doenças, na datação de achados arqueológicos, na esterilização de materiais, na agricultura, entre muitas outras aplicações.

Desta forma, após termos conhecido as radiações eletromagnéticas, suas características e aplicações, estudaremos agora as radiações corpusculares, ou seja, aquelas que são formadas por partículas elementares ou núcleos atômicos. Assim, o estudo do átomo e em particular, o núcleo atômico, será uma ferramenta muito útil para o entendimento dessa nova forma de radiação.

\section{A Estrutura do Átomo}

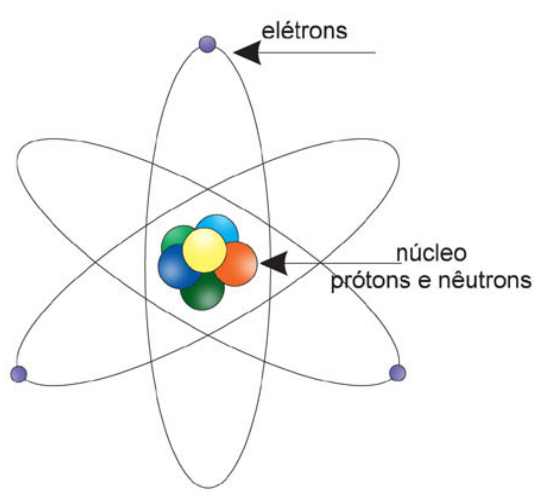

Modelo planetário do átomo
Desde os gregos até os modelos mais atuais, o átomo foi por muito tempo (e ainda é) um tema de pesquisa de muitos cientistas. Cada um deles, utilizando-se de teorias e/ou métodos experimentais, criou um modelo para representá-lo. Um modelo que geralmente pode ser usado para representar o átomo é aquele que se assemelha ao sistema solar em miniatura, também conhecido pelo nome de Modelo Planetário. 
Neste modelo, o átomo possui uma região central denominada de núcleo (a semelhança do Sol) bastante pequeno, onde se encontram os prótons (com carga elétrica positiva) e os nêutrons (com carga elétrica neutra), e onde está a maior parte da massa do átomo. Ao redor desse núcleo existe uma região chamada de eletrosfera, onde está uma configuração de partículas com carga elétrica negativa, denominadas de elétrons.

O átomo é algo realmente muito pequeno e em sua maior parte, um grande vazio. Para entendermos melhor isso, imagine que você esteja segurando uma bola de basquete enquanto alguns grãos de areia girem em torno da bola, a $25 \mathrm{~km}$ de distância. Imagine ainda que todo o espaço entre a bola e os grãos de areia, um espaço suficientemente grande para conter uma cidade inteira, está totalmente vazio. Sob certos aspectos, o interior do átomo é assim, só que em uma escala menor. A bola de basquete seria o núcleo, enquanto que os grãos de areia seriam os elétrons. Um outro exemplo para elucidar essa tamanha desproporção seria o seguinte: Do centro da cidade de São Paulo até o aeroporto de Cumbica em Guarulhos, a distância é de aproximadamente $25 \mathrm{~km}$. Assim, se "o núcleo do átomo, isto é, a bola de basquete estivesse colocada no centro da cidade de São Paulo, o elétron mais próximo estaria a $25 \mathrm{~km}$ dele, em outra cidade, em Guarulhos"! O que acha disso?

Experimentos revelaram que o diâmetro do átomo é da ordem de $10^{-10} \mathrm{~m}^{1}$, enquanto que o de seu núcleo é cerca de $10^{-15} \mathrm{~m}^{2}$, logo o diâmetro do átomo é cerca de 100.000 vezes maior que o diâmetro do seu núcleo, o que corresponderia em sua maior parte a um grande vazio. Entretanto sabemos hoje, que o elétron tem probabilidade de ocupar posições diferentes girando ao redor do núcleo, de modo que não caracteriza um vazio absoluto.

\section{A Estrutura do Núcleo}

Ernest Rutherford (1871-1937) ao fazer a sua famosa experiência sobre o "Espalhamento das Partículas Alfa" em 1911, descobriu a estrutura do núcleo atômico estudando a interação entre as partículas alfa e átomos de ouro. A partir disso, ele pôde concluir que no núcleo do átomo existia uma partícula positiva e que seria então chamada de próton, pois em latim significava "primeiro", uma vez que foi a primeira partícula do núcleo a ser descoberta.

O elétron já havia sido descoberto por Joseph John Thomson (1856-1940) em 1897 ao estudar os chamados raios catódicos e sua descoberta serviu como ponto de partida para estes estudos posteriores sobre o átomo, como a experiência de Rutherford, pois os resultados obtidos por Thomson apontaram que o átomo não tinha mais um caráter indivisível como até então se imaginava. Em 1932, James Chadwick (1891-1974) um contemporâneo de Rutherford, mostrou a existência de uma segunda partícula no interior do núcleo atômico. Esta partícula recebeu o nome de nêutron e apresentava carga elétrica neutra e massa muito próxima a do próton.

\footnotetext{
${ }^{1} 10^{-10} \mathrm{~m}=1$ Angstron $(1 \AA$ ) . Unidade muito usada para medidas da ordem do diâmetro do átomo.

${ }^{2} 10^{-15} \mathrm{~m}=1$ Fermi $(1 \mathrm{fm})$. Unidade muito usada para medidas da ordem do núcleo do átomo.
} 


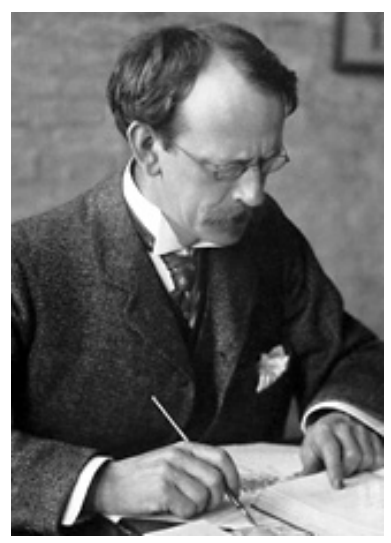

Joseph John Thomson

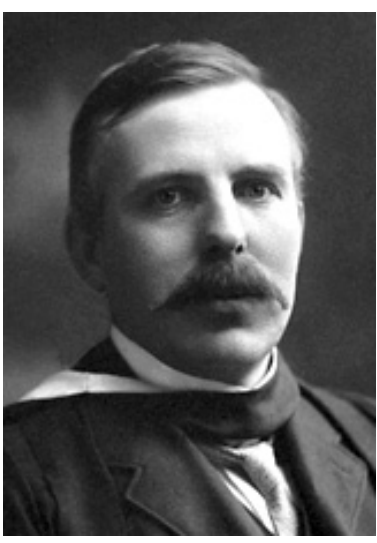

Ernest Rutherford

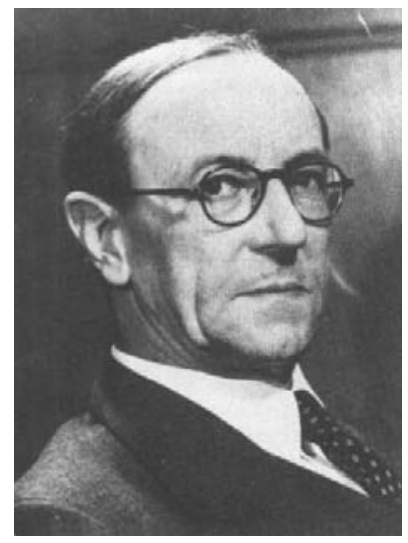

James Chadwick

A massa do próton é 1836 vezes maior que a massa do elétron e a massa do nêutron é 1839 vezes maior que a massa do elétron, assim prótons e nêutrons são responsáveis por quase toda a massa do átomo. Isso justifica a afirmação que praticamente toda a massa do átomo está concentrada em seu núcleo. Isto também justifica os espaços vazios no interior do átomo, uma vez que na eletrosfera onde encontramos os elétrons, temos partículas com pouquíssima massa, muito afastadas do núcleo e movimentando-se ao redor dele nas órbitas.

$\mathrm{Na}$ tabela a seguir, encontramos os valores das respectivas massas e cargas elétricas das partículas que constituem o átomo.

\begin{tabular}{|c|c|c|c|}
\hline Partículas & Massa (kg) & Massa $^{3} \mathbf{( u )}$ & Carga Elétrica $^{4}$ (C) \\
\hline Próton & $1,672622.10^{-21}$ & 1,007276 & $+1,602177.10^{-19}$ \\
\hline Nêutron & $1,674927.10^{-27}$ & 1,008665 & 0 \\
\hline Elétron & $9,109382.10^{-31}$ & $5,485799.10^{-4}$ & $-1,602177.10^{-19}$ \\
\hline
\end{tabular}

\section{Caracterizando um Átomo}

A característica mais importante de um átomo é o número de prótons do seu núcleo, que é chamado de número atômico e é representado pela letra $\mathbf{Z}$. É este número que define o elemento a que pertence o átomo. Assim, por exemplo, todos os átomos de ouro (número atômico 79) possuem 79 prótons. Na verdade, para os cientistas, o nome "ouro" é simplesmente uma forma compacta de dizer "átomo com 79 prótons". Todo elemento possui um número atômico: os átomos de hidrogênio têm 1 próton, os átomos de carbono têm 6 prótons e assim por diante.

Todos os átomos de um elemento possuem o mesmo número de prótons, mas o número de nêutrons pode variar. Em outras palavras, dois átomos com o mesmo número de prótons podem ter números diferentes de nêutrons. Nesse caso, dizemos que os dois átomos,

\footnotetext{
${ }^{3}$ A unidade de massa atômica é representada pela letra u e é medida em relação ao átomo de carbono-12. ${ }^{4}$ A carga elétrica é medida em Coulomb e é representada pela letra C. Esta carga corresponde a carga elementar do elétron que foi medida por Milikan em 1907.
} 
que possuem massas diferentes, são isótopos do elemento. A soma do número de prótons com o número de nêutrons é chamada de número de massa, sendo representada pela letra $\mathbf{A}$.

Portanto, para todo átomo podemos usar a seguinte representação ${ }_{Z}^{A} X$, onde $\boldsymbol{A}$ é o número de massa, $\boldsymbol{Z}$ representa o número atômico, enquanto $\boldsymbol{X}$ representa o símbolo do elemento. Logo, quando escrevemos ${ }_{26}^{56} \mathrm{Fe}$, estamos querendo dizer na verdade que o elemento representado pelo símbolo Fe, refere-se ao átomo de ferro, que possui 26 prótons e 30 nêutrons, pois subtraindo-se o seu número de massa $56 \quad(A=56)$ do número atômico 26 $(Z=26)$, obtemos o número de nêutrons $(N=A-Z)$ do elemento.

Todos os elementos possuem vários isótopos. No caso do carbono, por exemplo, 0 isótopo mais abundante é que possui 6 prótons e 6 nêutrons. Este isótopo, cujo número de massa é 12, é representado como ${ }^{12} \mathrm{C}$ ou carbono-12 e denominado "carbono doze". Outros isótopos do carbono, como carbono-13, com sete nêutrons, e o carbono-14, com oito nêutrons, possuem uma massa maior que o carbono-12.

\section{Questões}

1-) Imagine que uma bola de basquete fosse o núcleo de um átomo e que ela tivesse uma massa de $3 \mathrm{~kg}$. Se neste átomo existissem apenas 1 próton, 1 nêutron e 1 elétron, quanto valeria a massa do próton, do nêutron e do elétron, aproximadamente?

2-) Represente através do modelo planetário os isótopos do átomo de hidrogênio:

a) Prótio (conhecido como hidrogênio leve, possui apenas um próton e um elétron).

b) Deutério (conhecido como hidrogênio pesado, possui um próton, um elétron e um nêutron).

c) Trítio (conhecido como hidrogênio mais pesado, possui um próton, um elétron e dois nêutrons).

3-) Determine para os elementos ${ }_{20}^{40} \mathrm{Ca},{ }_{11}^{23} \mathrm{Na},{ }_{9}^{19} \mathrm{~F}$ e ${ }_{10}^{20} \mathrm{Ne}$, o seu número de prótons, elétrons e nêutrons. Entre eles, existem isótopos? Quais?

4-) Qual o significado da expressão: carbono-13 e carbono-14? O que estes elementos são entre si? 


\section{A Interação Nuclear e a Estabilidade do Núcleo}

Os prótons e nêutrons do núcleo
estão aglomerados em uma região aproximadamente esférica. Os experimentos revelam que o raio $r$ do núcleo depende do número de massa $\boldsymbol{A}$ e pode ser determinado aproximadamente, através da seguinte expressão: $r=\left(1,2 \cdot 10^{-15}\right) \cdot \sqrt[3]{A}$, com $r$ dado em metros $(m)$.

A partir dela podemos então, calcular o raio do alumínio $(A=27)$, por exemplo:

$$
r=\left(1,2 \cdot 10^{-15}\right) \cdot \sqrt[3]{27} \Rightarrow r=\left(1,2 \cdot 10^{-15}\right) \cdot 3 \Rightarrow r=3,6 \cdot 10^{-15} \mathrm{~m} .
$$

Este valor de raio encontrado, mais uma vez confirma o tamanho diminuto do núcleo atômico e a enorme proximidade entre os prótons e nêutrons. Diante disso, nos deparamos com um problema interessante no núcleo. Nele encontramos apenas partículas neutras (os nêutrons) e partículas positivas (os prótons). Sabemos que cargas elétricas de mesmo sinal se repelem, ou seja, sofrem uma força de natureza elétrica e repulsiva. Por que então a repulsão elétrica entre os prótons, que são positivos, não faz os núcleos se desintegrarem? Isso faz muito sentido, pois pensando em um átomo de oxigênio que possui $Z=8$, temos em seu núcleo 8 prótons confinados em um espaço muito pequeno, logo esses 8 prótons estariam exercendo entre si uma força de repulsão elétrica. Portanto, voltamos à questão: Por que os núcleos dos átomos não se desintegram?

Para que o núcleo seja estável, é preciso então que exista uma interação atrativa capaz de superar a repulsão elétrica dos prótons. Por esta razão, os físicos a chamaram de interação nuclear, uma manifestação da interação forte, uma das três interações fundamentais conhecidas, no sentido de que podem explicar todas as forças observadas na natureza. A interação nuclear deve agir apenas a pequenas distâncias, distâncias estas da mesma ordem que o tamanho do núcleo atômico, ou seja, distâncias da ordem de $10^{-15}$ metros ou 1 Fermi. Neste aspecto, a interação nuclear é muito diferente das interações já conhecidas como a gravitacional $^{1}$ e eletromagnética ${ }^{2}$, que agem a grandes distâncias. A interação nuclear se manifesta de forma igual entre prótons e nêutrons, não dependendo da carga elétrica.

O alcance limitado da interação nuclear desempenha um papel importante na estabilidade do núcleo. Para que um núcleo seja estável, é preciso que a repulsão elétrica entre os prótons seja compensada pela atração entre os núcleons devido à interação nuclear. Entretanto, um próton repele todos os outros prótons do núcleo, já que a interação eletromagnética é uma interação de longo alcance. Um próton ou um nêutron, por outro lado, atrai apenas os vizinhos mais próximos através da interação nuclear. Nessas condições,

\footnotetext{
${ }^{1}$ Interação gravitacional: ocorre entre massas.

${ }^{2}$ Interação eletromagnética: ocorre entre partículas carregadas eletricamente.
} 
quando o número $\mathrm{Z}$ de prótons do núcleo aumenta, o número $\mathrm{N}$ de nêutrons tem que aumentar ainda mais para que a estabilidade seja mantida.

Podemos considerar que existam cerca de 260 núcleos estáveis e centenas de outros núcleos instáveis. Uma representação gráfica útil na Física é um gráfico que apresenta $\mathrm{N}$ em função de $Z$ para os elementos estáveis encontrados na natureza. No gráfico abaixo, a linha reta (em amarelo) representa a condição onde $\mathrm{N}=\mathrm{Z}$, indicando que estes elementos por possuírem número de prótons e nêutrons iguais, são estáveis. Isso ocorre com núcleos leves. Com o aumento do número atômico $Z$, os pontos que apresentam núcleos estáveis se afastam cada vez mais dessa reta, refletindo o fato de que é preciso um número relativo de nêutrons cada vez maior para compensar a repulsão elétrica dos prótons.

\section{Linha de Estabilidade Nuclear}

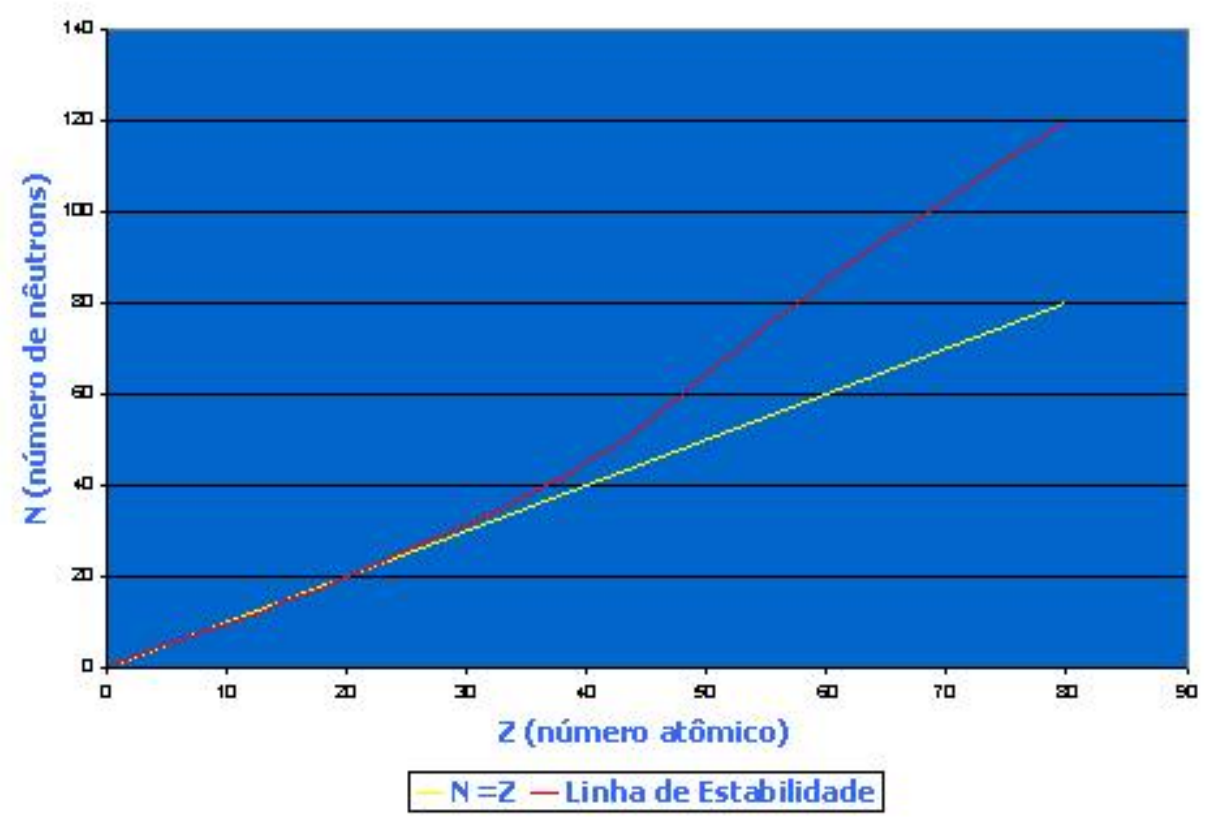

Com o aumento do número de prótons do núcleo, chega um ponto em que o aumento do número de nêutrons não é suficiente para compensar a repulsão elétrica. O núcleo estável com maior número de prótons $(Z=83)$ é o bismuto, ${ }_{83}^{209} \mathrm{Bi}$, que contém 126 nêutrons. Todos os núcleos com mais de 83 prótons, como por exemplo, o urânio $(Z=92)$ são instáveis e com o tempo se desintegram ${ }^{3}$ espontaneamente, até tornarem-se estáveis. Essa desintegração espontânea foi denominada de radioatividade e será estudada em breve.

É interessante mencionar que a maioria dos núcleos estáveis têm valores pares de número de massa (A). De fato, certos valores de $\mathrm{Z}$ e de $\mathrm{N}$ correspondem a núcleos que têm estabilidade excepcionalmente elevada. Esses valores de $\mathrm{N}$ e de $\mathrm{Z}$, chamados de números mágicos, são: $\mathbf{Z}$ ou $\mathbf{N}=2,8,20,28,50,82,126$. Por exemplo, o núcleo de hélio (dois prótons e dois nêutrons), que tem $Z=2$ e $N=2$, é muito estável. Isso acaba lembrando a estabilidade química dos gases nobres que recebem essa nomenclatura por possuírem em sua eletrosfera número de elétrons como $2,8,18,32$.

\footnotetext{
${ }^{3}$ Desintegração: emissão de partículas.
} 


\section{Unidades de medida}

Para medidas da massa do átomo e de sua energia, trabalhamos com unidades de medida não tão usuais quanto aquelas que estamos habituados a usar em nosso cotidiano. Quanto à massa do átomo ela pode ser expressa em termos da chamada unidade de massa atômica $^{4}(\mathbf{u})$, que corresponde a um padrão em relação ao átomo de carbono-12. Já para as medidas de energia, usamos o elétron-volt ${ }^{5}(\mathbf{e V})$ e os seus múltiplos: o quiloelétron-volt ${ }^{6}$ $(\mathbf{k e V})$ e o megaelétron-volt ${ }^{7}(\mathrm{MeV})$. Um elétron-volt corresponde a quantidade de energia igual àquela que 1 elétron adquire ao acelerar numa diferença de potencial de 1 volt.

Usando a relação de equivalência entre massa-energia de Einstein, isto é, a famosa expressão $E=m \cdot c^{2}$, podemos estabelecer as relações entre a massa atômica e o elétron-volt. Considerando o valor da velocidade da luz como sendo $c=3.10^{8} \mathrm{~m} / \mathrm{s}$ para o vácuo, temos então que:

$$
\begin{aligned}
& 1 \mathrm{u}=931,5 \mathrm{MeV} \text { (representa a energia da unidade de massa atômica) } \\
& m_{e}=511,0 \mathrm{keV}=0,511 \mathrm{MeV} \text { (representa a energia de repouso }{ }^{8} \text { do elétron) } \\
& m_{P}=938,7 \mathrm{MeV} \text { (representa a energia de repouso do próton) } \\
& m_{\mathrm{N}}=939,6 \mathrm{MeV} \text { (representa a energia de repouso do nêutron) }
\end{aligned}
$$

\section{Energia de Ligação Nuclear}

Quando pensamos em uma dúzia de laranjas e uma dúzia de maçãs, a massa total é simplesmente a soma das massas de todas as frutas. No caso dos núcleons (prótons e nêutrons) que formam o núcleo atômico, porém, a situação é diferente: a massa do núcleo é sempre ligeiramente menor que a soma das massas dos prótons e nêutrons. Quando os prótons e nêutrons se unem para formar um núcleo, parte de sua massa é transformada em energia e sabemos disso porque é preciso fornecer uma certa quantidade de energia ao núcleo para desintegrá-lo. Esta energia é denominada de energia de ligação nuclear (E) e é diferente para diferentes núcleos. Quanto mais estável for o núcleo, maior será a energia necessária para desintegrá-lo.

Para calcular a energia de ligação nuclear precisamos conhecer o chamado déficit de massa $(\Delta \mathbf{m})$ do núcleo que nada mais é do que a diferença entre a soma das massas dos prótons e nêutrons e a massa do núcleo, e que pode ser escrita da seguinte forma: $E=\Delta m . c^{2}$.

Como exemplo, vamos fazer o cálculo da energia de ligação nuclear do átomo de hélio4. Para determinar essa energia, calculamos primeiramente o déficit de massa $\Delta \mathrm{m}$. O hélio-4 é assim indicado, pois tem $Z=2$ prótons e $N=4-2=2$ nêutrons. Para obter o déficit de massa, calculamos a soma das massas dos prótons e nêutrons que compõem o núcleo e subtraímos

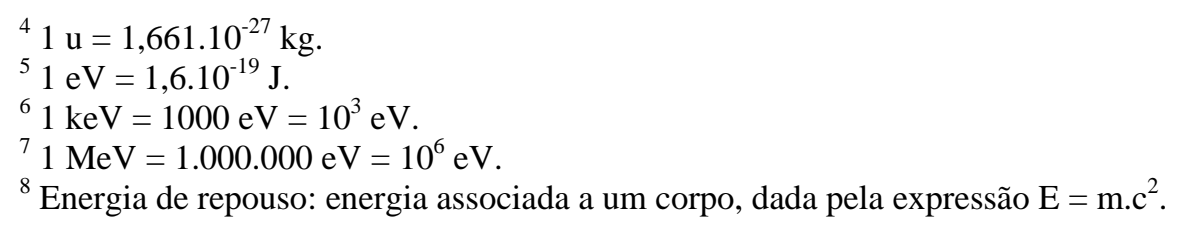


dessa soma a massa do núcleo de hélio-4 que é de $6,6447.10^{-27} \mathrm{~kg}$, valor este retirado de uma tabela de massa de átomos, encontrada em livros de física nuclear. Logo, temos:

$$
\left.\begin{array}{l}
m_{\text {próton }}=1,6726 \cdot 10^{-27} \mathrm{~kg} \\
m_{\text {nêutron }}=1,6749 \cdot 10^{-27} \mathrm{~kg} \\
m_{\text {núcleo }}=6,6447 \cdot 10^{-27} \mathrm{~kg}
\end{array}\right\} \begin{aligned}
& \text { Como temos } 2 \text { prótons e } 2 \text { nêutrons: } \\
& \frac{2 \cdot\left(1,6726 \cdot 10^{-27} \mathrm{~kg}\right)}{2 \cdot\left(1,6749 \cdot 10^{-27} \mathrm{~kg}\right)}+ \\
& 6,6950 \cdot 10^{-27} \mathrm{~kg}
\end{aligned}
$$

(Valor da soma das massas dos prótons e nêutrons)

\section{Déficit de massa:}

$\Delta \mathrm{m}=$ (soma das massas dos prótons e nêutrons) - (massa do núcleo)

$\Delta \mathrm{m}=6,6950.10^{-27} \mathrm{~kg}-6,6447.10^{-27} \mathrm{~kg}$

$\Delta \mathrm{m}=0,0503 \mathrm{~kg}$

$$
\begin{aligned}
& \text { Energia de ligação nuclear: } \\
& E=\Delta m \cdot c^{2} \\
& E=0,0503 \mathrm{~kg} \cdot\left(3 \cdot 10^{8} \mathrm{~m} / \mathrm{s}\right)^{2} \\
& E=4,53 \cdot 10^{12} \mathrm{~J}
\end{aligned}
$$

\section{Questões}

1-) Existe a interação nuclear entre nêutron e próton ou ela ocorre somente entre os prótons que estão sujeitos a repulsão elétrica? Justifique.

2-) É mais fácil remover do átomo um próton ou um elétron? Justifique.

3-) Qual a principal diferença entre a interação nuclear e as interações eletromagnética e gravitacional?

4-) O que significa dizer que um átomo é estável? E que um átomo é instável?

5-) Para que serve a energia de ligação nuclear?

6-) $O$ átomo de menor número de massa e maior número de massa e estáveis, tem respectivamente, $A=1$ (Hidrogênio) e $A=209$ (Bismuto). Qual o valor do raio atômico em cada caso?

7-) Sabendo que a massa atômica do ${ }_{82}^{206} \mathrm{~Pb}$ é $205,974440 \mathrm{u}$, determine:

a) o seu déficit de massa, em unidades de massa atômica (u);

b) a energia de ligação nuclear, em MeV. 


\section{Compreendendo os Decaimentos Radioativos}

Conforme foi visto anteriormente, grande parte dos núcleos com menos de 83 prótons são estáveis, pois a interação nuclear consegue manter os núcleons coesos. Entretanto, núcleos mais de 83 prótons são instáveis e com o tempo se desintegram espontaneamente. Ao se desintegrar, um núcleo emite certos tipos de partículas, acompanhadas ou não de fótons de alta energia. Esses fótons e partículas são chamados de "raios". Três tipos de raios são produzidos pelos núcleos radioativos: raios $\alpha$, raios $\beta$ e raios $\gamma$. Cada raio tem um poder de penetração: os raios $\alpha$ são os menos penetrantes, sendo bloqueados por uma folha fina de papel ( $\cong 0,01 \mathrm{~mm}$ de chumbo), enquanto que os raios $\beta$ precisam de uma espessura muito maior de chumbo ( $\cong 0,1 \mathrm{~mm}$ ) para serem bloqueados; os raios $\gamma$ sãos os mais penetrantes, podendo atravessar até $100 \mathrm{~mm}$ de chumbo.

Desta forma, conheceremos agora os processos de decaimento radioativo ou também chamado de desintegração nuclear, que produzem os raios $\alpha$ e $\beta$, que são radiações corpusculares. Os raios $\gamma$ embora sejam de natureza nuclear, não são radiações corpusculares e já foram discutidos nas radiações eletromagnéticas. Embora os processos de decaimento ocorram no núcleo do átomo, eles devem obedecer as leis de conservação que temos na Física, como a:

- Lei de Conservação da Carga Elétrica;

- Lei de Conservação da Massa;

- Lei de Conservação da Energia.

Assim, as quantidades de carga elétrica, massa e energia, antes e depois de qualquer decaimento radioativo, devem ser as mesmas. Isto é um dado muito útil ao conferirmos os mecanismos dos decaimentos e servem como uma prova de que eles de fato ocorrem e obedecem as leis de conservação.

\section{Decaimento alfa $(\alpha)$}

Quando um núcleo se desintegra e produz raios alfa, dizemos que sofreu um decaimento alfa. A partícula alfa tem carga elétrica +2 e número de núcleons $A=4$ e corresponde então a um núcleo de hélio sem elétrons, ou melhor, um núcleo duplamente ionizado $\left({ }_{2}^{4} \mathrm{He}^{2+}\right)$. Para fins de simplificação quando falarmos das partículas alfa, usaremos apenas a letra grega $\alpha$. Disso, concluímos que a partícula $\alpha$ é formada por 2 prótons e 2 nêutrons. Um exemplo de decaimento a é o do núcleo de urânio, que ao emitir uma partícula $\alpha$, sofre uma transmutação transformando-se em um núcleo de tório, conforme a equação: ${ }_{92}^{238} U \rightarrow{ }_{90}^{234} \mathrm{Th}+{ }_{2}^{4} \mathrm{He}^{2+}$, que também pode ser escrita da seguinte forma: ${ }_{92}^{238} U \rightarrow{ }_{90}^{234} \mathrm{Th}+\alpha$. 
O núcleo original é chamado de núcleo pai e o núcleo que resta após a desintegração é chamado de núcleo filho. Durante este processo podemos perceber de uma maneira muito fácil, a conservação da carga elétrica e da massa. Assim, o processo de decaimento a pode ser escrito de uma maneira geral da seguinte forma:

$$
\begin{gathered}
\left.{ }_{Z}^{A} P \rightarrow{ }_{Z-2}^{A-4} F+{ }_{2}^{4} \mathrm{He}^{2+} \quad \text { (Decaimento } \alpha\right) \\
\text { Núcleo Pai } \\
\text { Núcleo Filho } \\
\text { Partícula } \alpha
\end{gathered}
$$

Quando um núcleo emite uma partícula $\alpha$, ele também libera energia. Esta energia aparece como energia cinética do núcleo filho e da partícula $\alpha$, exceto por uma pequena parcela que se manifesta na forma de um raio $\gamma$. Para ilustrar a liberação de energia em um decaimento $\alpha$, vamos calcular o valor desta energia no decaimento que converte o urânio-238 em tório-234.

A massa atômica do ${ }_{92}^{238} U$ é 238,0508 u, a do ${ }_{90}^{234} T h$ é de 234,0436 u e a de uma partícula a $\left({ }_{2}^{4} \mathrm{He}\right)$ é 4,0026 u. Como é liberada energia no decaimento, sabemos que a soma da massa do ${ }_{90}^{234} \mathrm{Th}$ com a massa da partícula a é menor que a massa ${ }_{92}^{238} U$. A diferença entre essas massas é equivalente à energia liberada neste processo. Para determinar essa energia, basta calcular a diferença das massas em unidades de massa atômica e usar o fato de que $1 \mathrm{u}$ equivale a 931,5 MeV. Assim:

$\begin{array}{ccc}{ }_{92}^{238} U & \rightarrow{ }_{90}^{234} \mathrm{Th}+{ }_{2}^{4} \mathrm{He}^{2+} \\ \mathbf{2 3 8 , 0 5 0 8} \mathrm{u} & \frac{\mathbf{2 3 4 , 0 4 3 6} \mathrm{u}+\mathbf{4 , 0 0 2 6} \mathrm{u}}{\mathbf{2 3 8 , 0 4 6 2} \mathbf{u}}\end{array}$

A diferença de massa é 238,0508 u - 238,0462 u = 0,0046 u. Como 1 u equivale a 931,5 MeV, a energia liberada neste decaimento é de 4,3 MeV.

Uma das aplicações do decaimento a é na construção de detectores de fumaça. Estes detectores são compostos de duas pequenas placas de metal que são montadas a uma distância da ordem de um centímetro uma da outra. Uma pequena pastilha de material radioativo, geralmente Amerício-241, montada no centro de uma das placas emite partículas $\alpha$, que ao colidirem com as moléculas do ar acabam produzindo íons ${ }^{1}$ positivos e negativos.

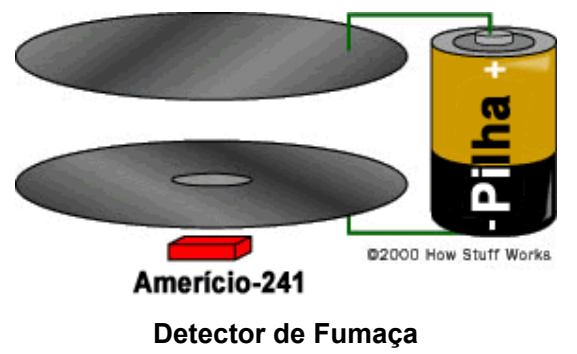

A tensão da pilha torna uma das placas positiva e a outra negativa, o que faz com que as placas atraíam esses íons. Em conseqüência disso, uma corrente elétrica atravessa o circuito. A presença de partículas de fumaça reduz essa corrente, pois os íons que colidem com uma partícula de fumaça quase sempre são neutralizados. A queda de corrente causada pela presença de partículas de fumaça é usada para disparar um alarme.

\footnotetext{
${ }^{1}$ Íons: átomos que perderam ou ganharam elétrons.
} 


\section{Decaimento beta menos $\left(\beta^{-}\right)$}

Os raios $\beta$ são defletidos pelo campo magnético na direção oposta à dos raios $\alpha$, que são partículas positivas. Assim, os físicos chegaram à conclusão de que esses raios são formados por partículas de carga negativa, que foram chamadas inicialmente de partículas $\beta$. Mais tarde descobriu-se que estas partículas $\beta^{-}$são na verdade elétrons $(\boldsymbol{e})$. Como exemplo do decaimento $\beta^{-}$, podemos considerar o núcleo do tório-234 que decai em um núcleo de protactínio-234, emitindo uma partícula $\beta^{-}$, conforme a equação: ${ }_{90}^{234} \mathrm{Th} \rightarrow{ }_{91}^{234} \mathrm{~Pa}+\boldsymbol{e}$.

Assim como o decaimento $\alpha$, o decaimento $\beta^{-}$também causa uma transmutação e obedece as leis de conservação. Desta forma, podemos escrever o decaimento $\beta^{-}$da seguinte forma geral:

$$
\begin{gathered}
{ }_{Z}^{A} P \\
\text { Núcleo Pai }
\end{gathered} \underset{Z+1}{{ }_{\text {Núcleo Filho }}^{A} F}+\underset{\text { Partícula } \beta}{\text { - }}
$$

Fica então uma pergunta: Se os processos de decaimento radioativo são de origem nuclear, ou seja, as partículas são emitidas pelo núcleo do átomo, como um elétron pode ser emitido pelo núcleo se no núcleo temos apenas os núcleons (prótons e nêutrons)?

Esta questão atormentou os físicos durante muito tempo e a sua resposta, levou a descoberta de uma nova partícula. Essa nova partícula recebeu o nome de neutrino, dado pelo físico Enrico Fermi (1901-1954), em 1934 de, cujo símbolo é v. Esta partícula é neutra e sua massa é muito pequena, quase imperceptível.

Foi o físico Wolfgang Pauli (1900-1950) que na década de 30, explicou de maneira coerente o decaimento $\beta^{-}$. Na verdade o que é emitido pelo núcleo no decaimento $\beta^{-}$é um nêutron $(n)$ que sofre um decaimento em três outras partículas, um próton (p), um elétron (e) e a nova partícula, o neutrino $(v)$. Podemos representar o processo pela seguinte equação $n \rightarrow p+e+v$, onde o próton permanece no núcleo do átomo, enquanto o elétron (e) é emitido com alta energia, deixando para trás um átomo com número atômico $Z$ aumentado em 1 unidade $(Z+1)$. $O$ neutrino é necessário neste processo para garantir a conservação de energia, entretanto, por fins didáticos, omitimos o neutrino na equação do decaimento $\beta^{-}$e $\beta^{+}$ que será estudado a seguir.

\section{Decaimento beta mais $\left(\beta^{+}\right)$}

Um segundo tipo de decaimento $\beta$ também é observado, sendo chamado de decaimento $\beta^{+}$. Neste processo, a partícula emitida pelo núcleo é um pósitron em vez de um elétron. $O$ pósitron, que também é chamado de partícula $\beta^{+}$, tem a mesma massa que 0 elétron, mas possui uma carga positiva, sendo então representada da seguinte forma ${ }_{+1} e .0$ pósitron é a antipartícula do elétron. Desta forma, podemos escrever o decaimento $\beta^{+}$da seguinte forma geral: 


\section{${ }_{Z}^{A} P \quad \rightarrow \quad{ }_{Z-1}^{A} F \quad+\quad{ }_{+1} e \quad\left(\right.$ Decaimento $\left.\beta^{+}\right)$ \\ Núcleo Pai Núcleo Filho Partícula $\beta^{+}$}

Assim como no decaimento $\beta^{-}$, o pósitron emitido no decaimento $\beta^{+}$não estava no núcleo antes do decaimento e o que acontece é o seguinte: um prótron (p) sofre um decaimento em três outras partículas, um nêutron $(n)$, um pósitron $\left({ }_{+1} e\right)$ e um neutrino $(v)$, conforme a equação: $p \rightarrow n+{ }_{+1} e+v$. O nêutron permanece no núcleo do átomo, enquanto o pósitron $\left({ }_{+1} e\right)$ é emitido com alta energia, deixando para trás um átomo com número atômico Z, diminuído em uma unidade, ou seja, Z-1, uma vez que temos um próton a menos no núcleo. O neutrino é necessário neste processo para garantir a conservação de energia. A energia liberada nos decaimentos $\beta^{-}$e $\beta^{+}$, podem ser calculadas de maneira semelhante ao cálculo feito no decaimento $\alpha$.

\section{Decaimento gama $(\gamma)$}

O decaimento $\gamma$ não é caracterizado por nenhuma partícula, pois é na verdade, uma radiação eletromagnética. Isso já foi contemplado no estudo do espectro eletromagnético. Essa radiação pode ser representada pelos seus fótons de alta energia, algo característico a esta radiação. Quando um núcleo faz um decaimento radioativo, ele passa de um estado excitado (representado aqui por um asterisco) para um estado de menor energia, não tendo alteração alguma em massa e carga elétrica. Podemos representar o decaimento $\gamma$ de forma geral da seguinte forma geral:

\section{${ }_{Z}^{A} P^{*} \rightarrow{ }_{Z}^{A} F+\gamma \quad$ (Decaimento $\gamma$ ) \\ Núcleo Pai Núcleo Filho raio $\gamma$}

Desta forma, após o decaimento o núcleo pai e núcleo filho apresentam o mesmo valor de $\mathrm{A}$ e $\mathrm{Z}$, diferindo apenas quanto à energia. Neste processo um elemento não se transforma em outro como nos decaimentos $\alpha, \beta^{-}$e $\beta^{+}$.

\section{Questões}

1-) Qual a diferença entre os decaimentos $\alpha, \beta^{-}$e $\beta^{+}$?

2-) Escreva a reação do decaimento $\beta^{-}$do ${ }_{16}^{35} S$ (enxofre-35), identificando o símbolo químico e os valores de $\mathrm{A}$ e $\mathrm{Z}$ do núcleo filho.

3-) Determine a energia liberada, em $\mathrm{MeV}$, quando o ${ }_{82}^{211} \mathrm{~Pb}$ (chumbo-211) de massa atômica 210,998735 u sofre um decaimento $\beta^{-}$e se transforma em ${ }_{83}^{211} B i$ (bismuto-211) de massa atômica 210,987255 u.

4-) Por que os decaimentos $\alpha$ e $\beta$ produzem novos elementos e o decaimento $\gamma$ não? 


\section{A descoberta da Radioatividade ${ }^{1}$}

No dia 20 de janeiro de 1896, Antoine Henri Becquerel (1852-1908) tomava conhecimento da descoberta dos raios X pelo físico Wilhelm Conrad Röntgen (1845-1923). Físico francês da terceira geração da família Becquerel, tinha muito interesse na fosforescência e na fluorescência dos materiais. Estes termos, fosforescência e fluorescência, não são sinônimos. Na fluorescência a emissão luminosa ocorre enquanto houver estímulo, a absorção e a emissão ocorrem rapidamente. Na fosforescência, mesmo cessado o estímulo, haverá a emissão, pois o processo de emissão é mais lento que na fluorescência.

Becquerel imaginou se havia uma relação entre raios $X$ e a fluorescência, ou seja, se algumas substâncias fluorescentes poderiam emitir raios $\mathrm{X}$ espontaneamente. Depois de descobrir que muitos elementos

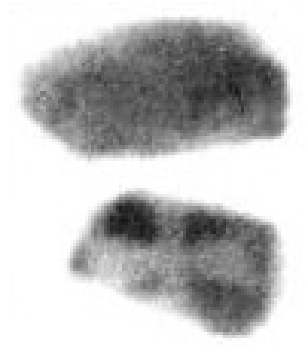
não produziam qualquer efeito, passou a utilizar materiais fosforescentes.

Ele utilizou sulfato de potássio e urânio, sal de urânio que era conhecido por suas propriedades fosforescentes. Cobriu uma chapa fotográfica com duas folhas de papel escuro grosso, tão grosso que a chapa não ficou manchada ao ser exposta ao Sol durante um dia inteiro. Colocou sobre o papel uma camada da substância fosforescente e para ativar a fosforescência do sal de urânio, e expôs tudo ao Sol por várias horas. Quando revelou a chapa fotográfica, percebeu a silhueta da substância fosforescente em escuro sobre o negativo. Concluiu que a substância emitia radiações capazes de atravessar a folha de papel opaca à luz. Tudo se passava como se o sal de urânio emitisse raios $X$.

Em 24 de fevereiro de 1896, Henri Becquerel fez um relatório de sua experiência e apresentou à Academia de Ciências em Paris. No entanto, em 2 de março, Becquerel anunciava aos seus pares da academia algo mais extraordinário. Durante a semana havia tentado repetir a experiência, preparando uma nova placa fotográfica enrolada no papel e no sal de urânio. Aconteceu que o tempo havia piorado e ele ficou impossibilitado de realizar a exposição ao Sol. Então guardou o conjunto numa gaveta à espera de melhores dias. $\mathrm{Na}$ véspera da seção da academia, como o tempo permaneceu encoberto, decidiu, mesmo assim, revelar as placas, esperando encontrar o negativo em branco. Para sua surpresa os negativos mostravam uma mancha de grande intensidade. Conclui que o sal de urânio emitia raios capazes de atravessar o papel preto, quer tivesse sido exposto ou não ao Sol. Sem dúvida, alguma emissão desconhecida estava saindo do sal, atravessando o papel e chegando até a chapa fotográfica. Essas emissões foram chamadas de raios de Becquerel.

Pouco tempo depois, em 9 de março de 1896 já descobrira que a radiação emitida pelo sal de urânio não apenas escurecia as chapas fotográficas protegidas, como também ionizava gases, isto é, provocava a libertação de elétrons dos átomos do gás, que por esse motivo ficavam carregados positivamente (falta de elétrons), transformando estes gases em

\footnotetext{
${ }^{1}$ Texto original do trabalho de mestrado de Maxwell Roger Siqueira.
} 
condutores de eletricidade. A partir daí, era possível medir a "atividade" de uma amostra simplesmente medindo a ionização que ela produzia.

O instrumento usado para a medição da ionização que o gás sofria era um rústico eletroscópio de lâminas de ouro. Este instrumento é constituído de duas folhas metálicas, neste caso de ouro, finas e flexíveis, ligadas em sua parte superior a uma haste, que se prende a uma placa condutora. Normalmente, as folhas metálicas são mantidas dentro de um frasco vidro transparente e seco, a fim de aumentar a sua sensibilidade e diminuir efeitos do ambiente externo. $O$ isolante impede a passagem de cargas elétricas da haste para 0 vidro. Aproximando-se da placa um tubo com o gás ionizado, isto é eletrizado, ocorrerá a indução eletrostática, ou seja: se o gás estiver carregado negativamente, ele repele os elétrons livres da placa para as lâminas de ouro, fazendo com que elas se abram devido à repulsão. Se o gás estiver com cargas positivas, ele atrai os elétrons livres das lâminas, fazendo também com que elas se abram, novamente, devido à repulsão. A determinação do sinal da carga do gás em teste, que já se sabe estar eletrizado, é obtida carregando-se anteriormente o eletroscópio com cargas de sinal conhecido. Dessa forma, as lâminas terão uma determinada abertura inicial. Pode-se observar isso nas figuras I (neutro) e II (eletrizado):

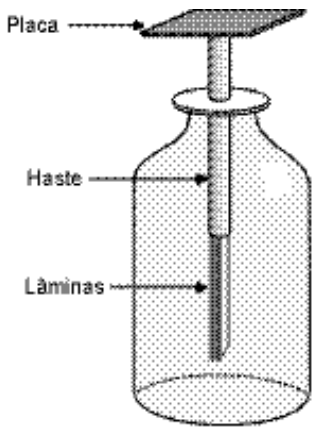

Figura I

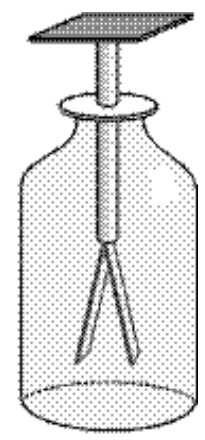

Figura II

A essa altura, um casal de cientistas iniciava suas investigações sobre a radioatividade em Paris, estudando vários minérios, uma vez que Henri Becquerel focalizou suas pesquisas somente no urânio. Marie Sklodowska Curie (1867-1934), polonesa, e seu marido francês Pierre Curie (1859-1906), após analisar vários compostos de urânio, verificaram a constatação de Becquerel, confirmando que a emissão de raios é uma propriedade do elemento urânio e assim, decidiram examinar todos os elementos conhecidos. Descobriram que também o tório emitia raios semelhantes aos do urânio.

Nesse ponto, depois de descobrirem que o urânio não era o único elemento a emitir radiação espontaneamente, Marie decidiu então, analisar todos os minérios naturais e para sua surpresa um mineral de urânio (uranita) era três ou quatro vezes mais radioativo do que se esperava. Desta forma concluiu que um elemento extremamente radioativo deveria existir enquanto impureza nesse minério. Depois de um longo e exaustivo trabalho, em julho de 1898, Marie com a ajuda de seu marido Pierre, conseguiu isolar a impureza e perceberam que se tratava de um novo elemento, que designaram de polônio, em homenagem ao país de origem de Marie, a Polônia. Ao aprimorar mais os seus métodos de purificação da uranita, o casal Curie, acabou por encontrar, em setembro desse mesmo ano, um elemento altamente radioativo que recebeu o nome de rádio. Marie propôs a palavra Radioatividade para esse fenômeno. 
Por esses feitos, Marie recebeu dois prêmios Nobel, um de Química e outro de Física. Infelizmente, foi uma das primeiras vítimas dos efeitos da radiação, assim como todos aqueles que se dedicaram ao estudo dos fenômenos da radioatividade no mesmo período.

\section{A descoberta das Radiações}

Após a descoberta dos raios X e da radioatividade, Ernest Rutherford (1871-1937), cientista nascido na Nova Zelândia, deu contribuições decisivas para a compreensão da natureza das substâncias radioativas e das suas radiações. Rutherford e seu colaborador Joseph John Thomson (1856-1940) dedicavam-se a medir a ionização nos gases provocada pelos raios $\mathrm{X}$ e pelas radiações emitidas pelo o urânio.

Em longo trabalho no laboratório Cavendish, Rutherford percebeu, em 1898, a existência de dois tipos diferentes de radiações emitidas pelo urânio, devido a penetração que tinham na matéria. Os raios que são menos penetrantes ele designou por raios alfa ( $\alpha$ ) e, os raios que penetravam mais de raios beta $(\beta)$. Além da diferença na penetração na matéria, ele percebeu que os raios alfa e beta eram defletidos para lados opostos quando passavam por uma região com campo magnético ou campo elétrico. Disso ele pode concluir que eles tinham carga elétrica oposta.

Com o resultado das experiências realizadas por Rutherford, bem como a de outros cientistas como Becquerel, concluiu-se em poucos anos que os raios beta ( $\beta$ ) são raios catódicos (elétrons). Entretanto, Paul Ulrich Villard (1860-1934), na França, descobriu uma terceira forma de radiação que era muito mais penetrante que as duas anteriores, que designou por raios gama $(\gamma$ ). Estes não eram sensíveis ao campo magnético, ou seja, não eram desviados e surgiram como uma espécie de raios $X$ mais energéticos. $O$ esclarecimento da natureza dos raios $\alpha$ continuou um mistério durante alguns anns.

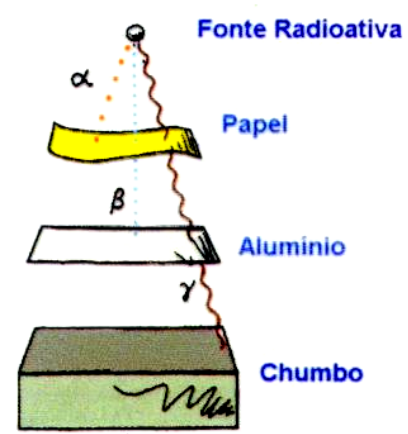

Penetração das radiações na matéria

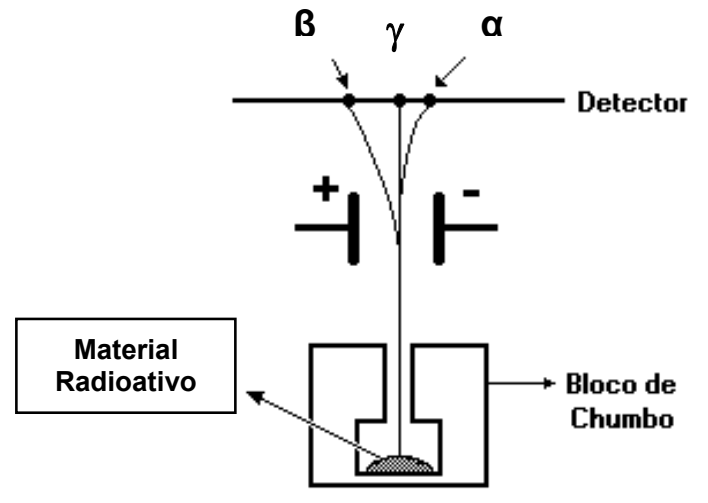

Desvios das radiações em um campo elétrico

Ao se mudar para Toronto, no Canadá, Rutherford pode observar outro fenômeno misterioso. Ao isolar a parte radioativa do sal de urânio, ele pode perceber, que com o passar do tempo, ela perdia a sua radiação, em contra partida a solução que havia retirado o elemento radioativo recuperava a radioatividade inicial. Trabalhando com o químico Frederick Soddy 
(1877-1966), Rutherford chegou a um resultado que implicava na transmutação ${ }^{2}$ entre os elementos, algo que foi anunciado com muita cautela ao anunciar, pois lembrava fortemente o antigo sonho dos alquimistas ${ }^{3}$.

Para fundamentar sua conclusão sobre a transmutação dos elementos, Rutherford teve que investigar mais a natureza das radiações alfa ( $\alpha$ ). Entre 1900 e 1903, através das medidas da razão entre a massa e carga elétrica das partículas $\alpha$, ele pode concluir que estas são, na verdade, núcleo do átomo de Hélio $(\mathrm{He})$. Resolvendo assim o problema da transmutação dos elementos que pôde ser explicado da seguinte maneira: os átomos instáveis (radioativos) emitem as radiações $\alpha$ e $\beta$, ao fazerem isso eles mudam suas propriedades químicas, transformando-se em outro de elemento (transmutação). A seguir temos um exemplo da transmutação do elemento tório-232 em rádio-228, após a emissão de uma radiação $\alpha$ :

$$
{ }^{232} \mathrm{Th} \rightarrow{ }^{228} \mathrm{Ra}+\alpha
$$

\section{Questões}

1-) Qual foi a principal contribuição que os Curie deram para a Radioatividade?

2-) Qual o termo mais adequado para designar as lâmpadas que iluminam as salas de aula?

3-)Qual foi a principal contribuição que Rutherford deu para a radioatividade?

4-) Quais são as principais diferenças entre as radiações alfa e beta?

5-) Por que a radiação gama $(\gamma)$ não sofre desvio ao passar por uma região de campo eletromagnético?

\footnotetext{
${ }^{2}$ Transmutação: Conversão do núcleo atômico de um elemento no núcleo atômico de um outro elemento, pela perda ou ganho de prótons.

${ }^{3}$ Alquimista: Praticante de uma forma primitiva de química, chamada de alquimia, associada com a magia. O objetivo da alquimia era transformar metais ordinários em ouro e descobrir uma poção que possibilitasse a juventude eterna.
} 
Welcome to Powers of Ten. Travel across the Universe. Changing scale by just a few powers of ten dramatically alters your perspective.

$\underline{\text { Start }}$

What is a Power of Ten?

Credits 


\section{LU II POWERS OF TEN $\triangle$ stART}

\section{$10^{12}$ metres $=1000000000000$ metres}

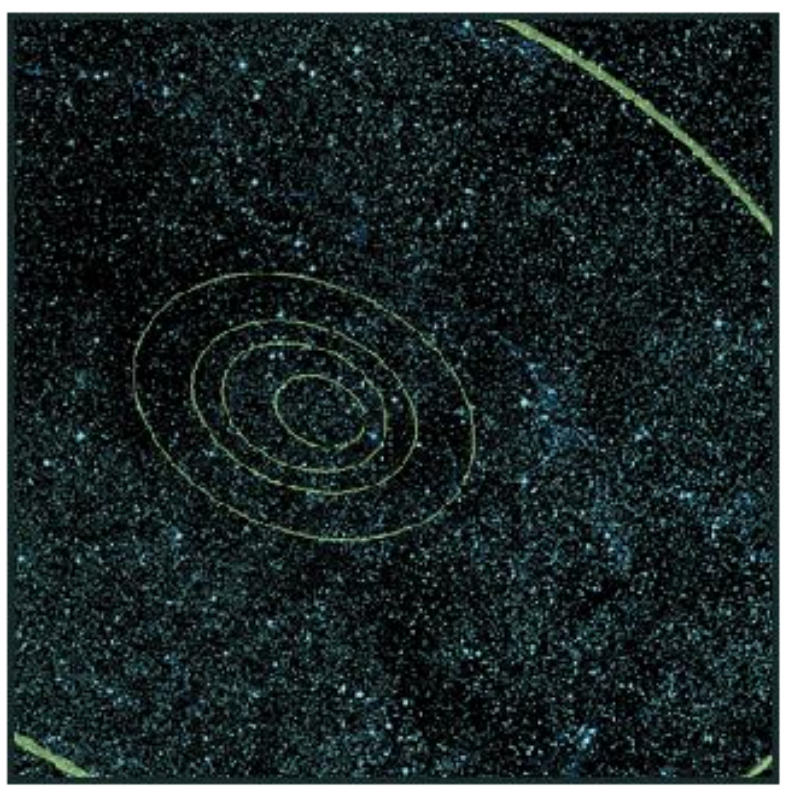

The orbits of the inner four planets : Mercury, Venus, Earth and Mars. All four have rocky crusts and metallic cores. 


\section{P-8 - Microsoft Internet Explorer}

\begin{tabular}{l} 
Arquivo Editar Exibir Favoritos Ferramentas Ajuda \\
\hline$-\Theta-x]$
\end{tabular}

\section{LE LI POWERS OF TEN $\$$ START}

\section{$10^{-8}$ metres $=0.00000001$ metres}

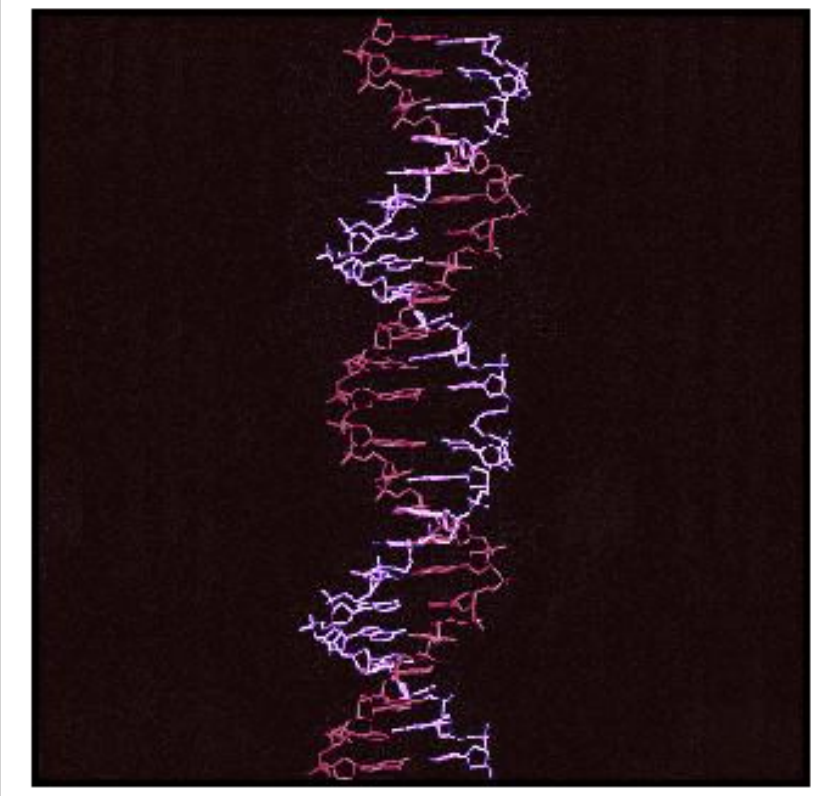

At the centre of the cell is a tightly coiled molecule called DNA. It contains the genetic material needed to duplicate the fly.

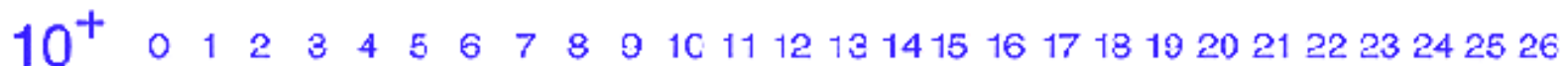

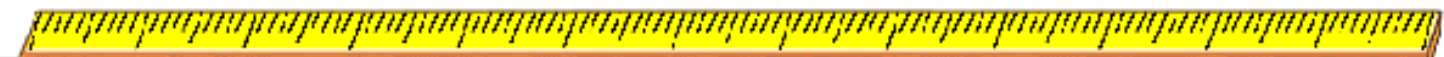

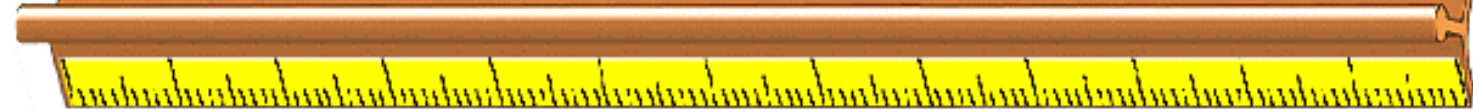

$10^{-} \quad 0 \quad 1 \quad 2 \quad 3 \quad 4 \quad 5 \quad 6 \quad 7 \quad 8 \quad 9101112131415$ 


\section{IS POWERS OF TEN $\square$ START}

\section{$10^{-10}$ metres $=0.0000000001$ metres}

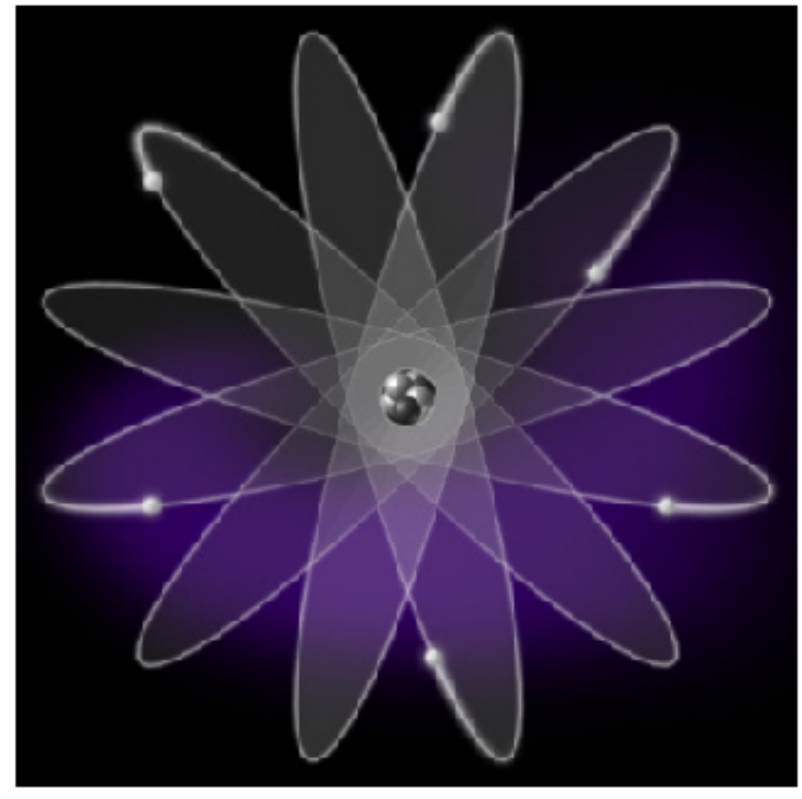

The carbon atom, an essential ingredient for life, is mostly empty space. A cloud of six negatively charged electrons orbits the positively charged nucleus.

From $10^{-10} \mathrm{~m}$ to $10^{-13} \mathrm{~m}$ not much changes.

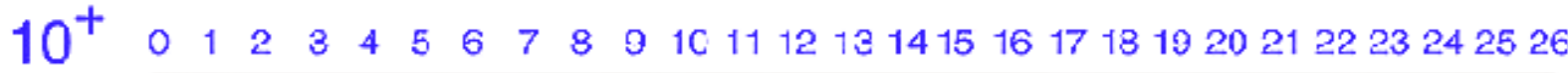

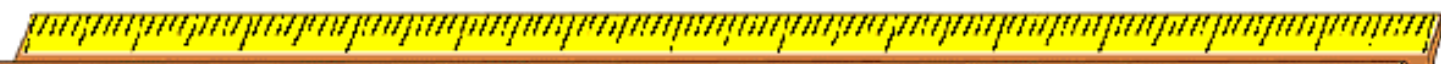

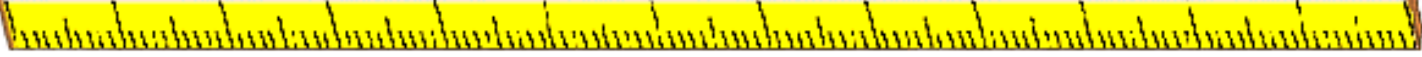

$10^{-} \quad 0 \quad 1 \quad 2 \quad 3 \quad 4 \quad 5 \quad 6 \quad 7 \quad 8 \quad 9 \quad 101112131415$ 


\section{LU II POWERS OF TEN $\square$ stART}

\section{$10^{-14}$ metres $=0.00000000000001$ metres}

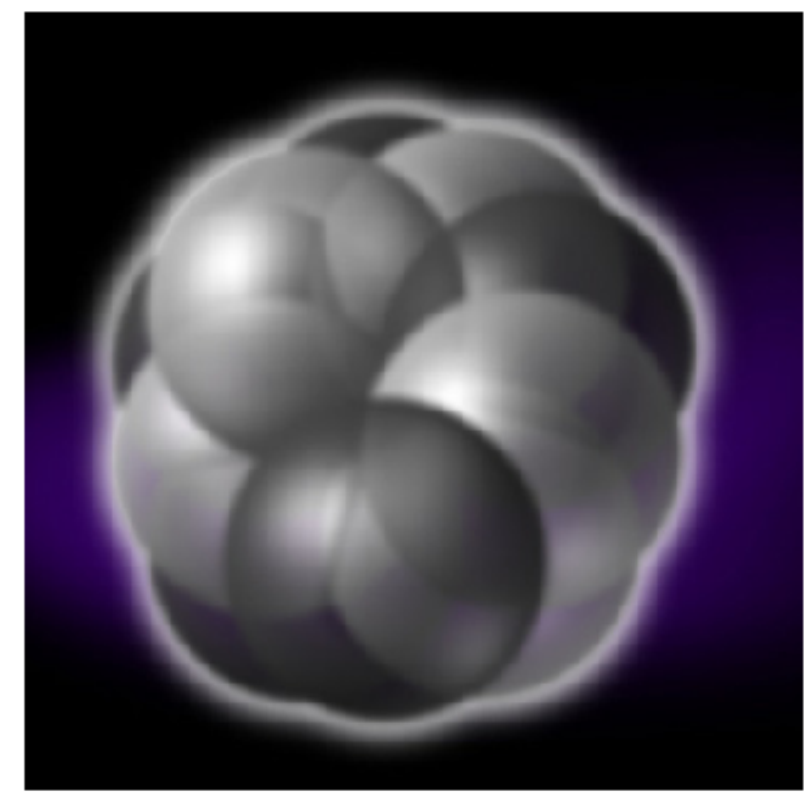

At the centre of the carbon atom is a nucleus made of six protons and six neutrons. $99.95 \%$ of the mass of the atom is concentrated in this tiny space.

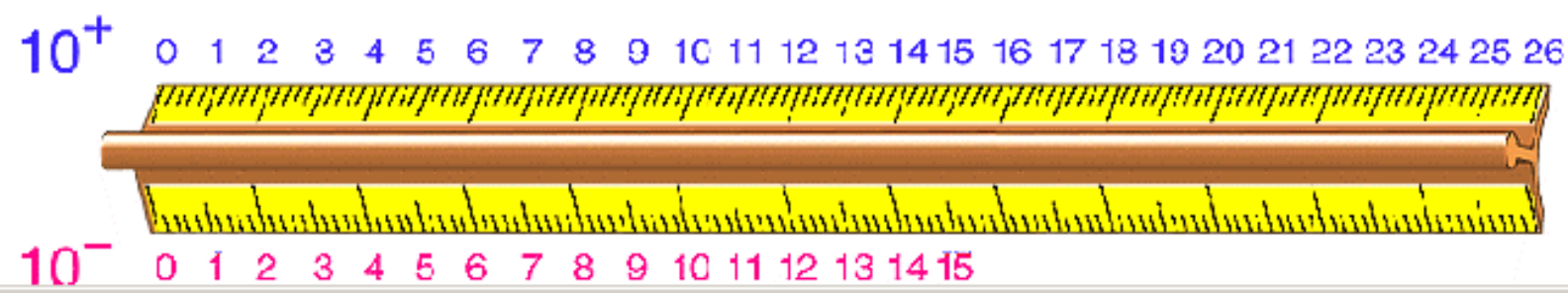




\section{LU LOWERS OF TEN $\$$ START}

\section{$10^{-15}$ metres $=0.000000000000001$ metres}

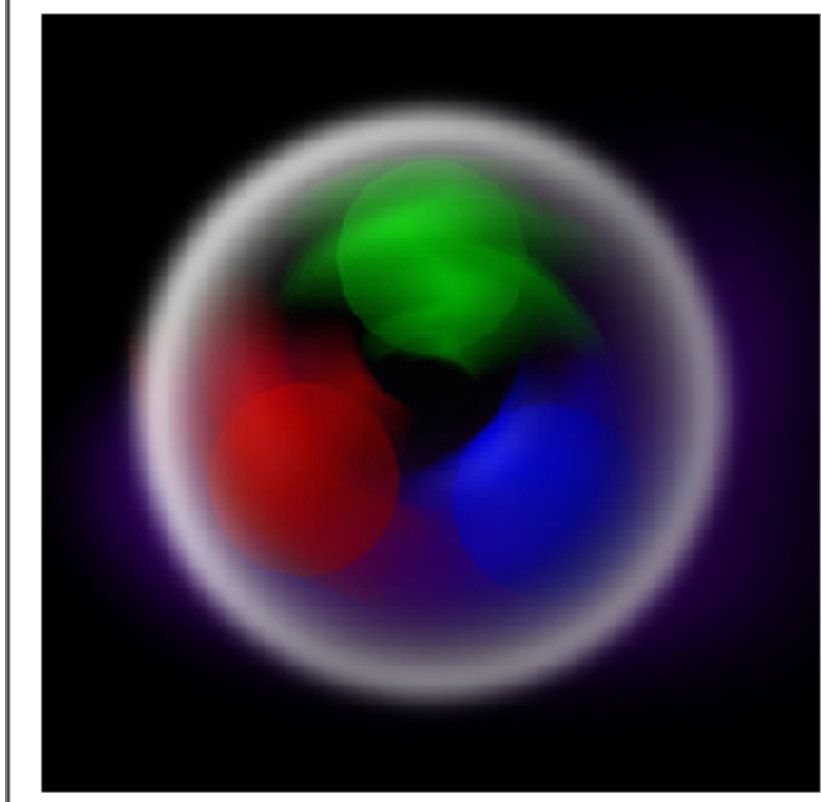

Protons and neutrons in the nucleus are made of 3 quarks. Quark interactions are studied at CERN to learn how particles formed in the very early Universe.

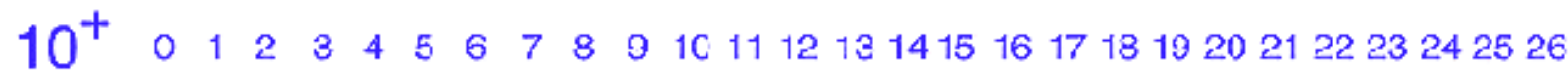

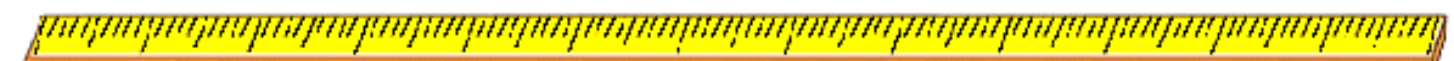

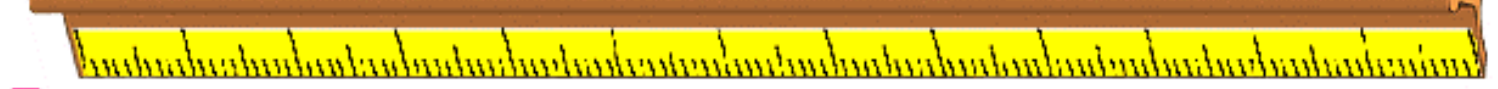

$\begin{array}{llllllllllllllllllll} & 10^{-} & 0 & 1 & 2 & 3 & 4 & 5 & 6 & 7 & 8 & 9 & 10 & 11 & 12 & 13 & 14 & 15\end{array}$ 
Física das Radiações: Uma Proposta para o Ensino Médio

\section{Atividade 6 - Visualizando o "Muito Pequeno"}

\section{Investigando 6a: Cortando papel para chegar a prótons}

Objetivo: Tentar dar uma idéia do tamanho dos objetos estudados na Física das Radiações.

\section{Material}

- Folha de papel A4.

- Tesoura ou régua.

\section{Orientações}

1-) Pegue a folha de papel e corte-a no meio. Com uma das metades, faça outro corte, também ao meio. Repita esse procedimento quantas vezes forem possíveis até chegar a um pedaço que você não consiga mais cortar.

2-) Conte os números de cortes feitos e faça a medida do menor pedaço de papel que você conseguiu.

\begin{tabular}{|c|c|c|}
\hline & $\mathrm{N}^{\circ}$ de cortes & Medida do papel \\
\hline Cortes a mão & & \\
\hline Cortes com tesoura & & \\
\hline
\end{tabular}

\section{Ordem de Grandeza e potência de 10}

Quando estudamos Física de Partículas é inevitável, a utilização de valores muito pequenos ou muito grandes, que não fazem parte de valores utilizados no dia a dia. Considere os exemplos abaixo:

Se alguém lhe dissesse que o tamanho de um átomo é aproximadamente $0,0000000001 \mathrm{~m}$, você dificilmente assimilaria essa idéia, por se tratar de um valor totalmente fora daqueles utilizados por você.

Se o núcleo de um átomo de hidrogênio fosse do tamanho da cabeça de um alfinete $(1 \mathrm{~mm})$, então o elétron no átomo estaria, aproximadamente, a uns $50 \mathrm{~m}$ de distância.

Estes números podem ser representados como um produto de um número por uma potência de dez, denominada notação cientifica, fácil de interpretar, comparar e operacionalizar.

Veja como se representam alguns valores em notação cientifica:

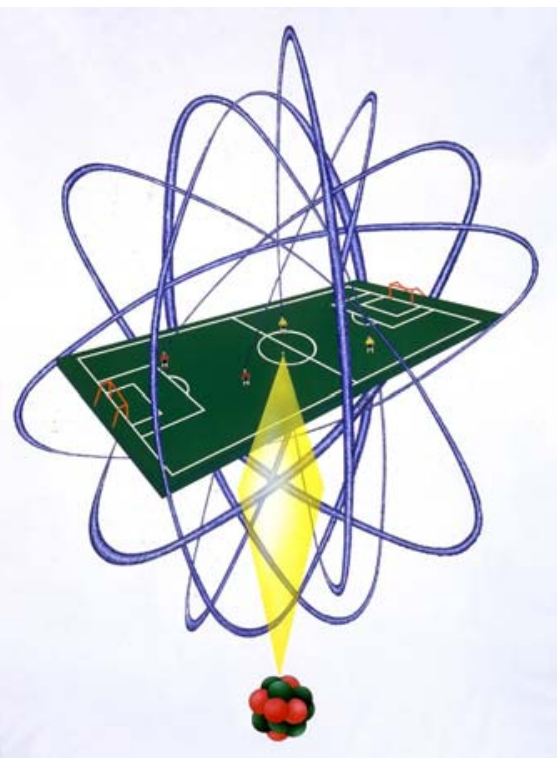

$$
\begin{aligned}
& 200 \mathrm{~m}=2 \times 100 \mathrm{~m}=2 \times 10^{2} \mathrm{~m} \\
& 5300 \mathrm{~m}=5,3 \times 1000 \mathrm{~m}=5,3 \times 10^{3} \mathrm{~m} \\
& 0,007 \mathrm{~cm}=\frac{7}{1000} \mathrm{~cm}=\frac{7}{10^{3}} \mathrm{~cm}=7 \times 10^{-3} \mathrm{~cm}
\end{aligned}
$$




\section{Exercícios}

I - Escreva os números abaixo em notação cientifica:

a) o diâmetro do próton $0,000000000000001 \mathrm{~m}=$

b) o diâmetro do átomo 0,000 $0000001 \mathrm{~m}=$

c) a velocidade da luz no vácuo $300000000 \mathrm{~m} / \mathrm{s}=$

d) a massa da Terra $5980000000000000000000000 \mathrm{Kg}=$

e) a carga de um elétron - 0,000 $00000000000000016 \mathrm{C}=$

II - Considerando as dimensões atômicas e subatômicas listadas abaixo, complete a tabela e responda:

\begin{tabular}{|c|c|c|c|}
\hline DIMENSÃO & DECIMAL & FRAÇÃO & POTÊNCIA DE 10 \\
\hline $\begin{array}{c}\text { Menor } \\
\text { objeto visto } \\
\text { a olho nu }\end{array}$ & $0,00001 \mathrm{~m}$ & & \\
\hline $\begin{array}{c}\text { diâmetro } \\
\text { aproximado } \\
\text { de um } \\
\text { átomo }\end{array}$ & $0,0000000001 \mathrm{~m}$ & & \\
\hline $\begin{array}{c}\text { diâmetro } \\
\text { aproximado } \\
\text { de um } \\
\text { núcleo }\end{array}$ & $0,00000000000001 \mathrm{~m}$ & & \\
\hline $\begin{array}{c}\text { diâmetro } \\
\text { aproximado } \\
\text { de um } \\
\text { próton }\end{array}$ & $0,000000000000001 \mathrm{~m}$ & & \\
\hline
\end{tabular}

1. Quantas vezes um núcleo típico é maior do que um próton?

2. Quantas vezes um átomo típico (o tamanho determinado pelos elétrons mais externos) é maior que um núcleo típico?

3. Quantas vezes uma cabeça de alfinete $\left(1 \mathrm{~mm}=10^{-3} \mathrm{~m}\right)$ é maior que um átomo típico?

4. Quantos átomos há na espessura de papel $A 4$, considerando que uma folha de papel A4 tenha espessura igual á um décimo de milímetro?

5. Se um átomo fosse do tamanho de uma cabeça de alfinete, qual seria a espessura de uma folha de papel?

Investigando 6b: O que têm dimensões com as seguintes ordens de grandeza?

Entre no site do cern :

http://microcosm.web.cern.ch/microcosm/p10/english/welcome.html, escreva o que você visualiza com dimensões nas seguintes ordens de grandeza.

\begin{tabular}{|c|c|}
\hline Ordem de grandeza (m) & O que você visualiza? \\
\hline $10^{26}$ & \\
\hline $10^{12}$ & \\
\hline $10^{0}$ & \\
\hline $10^{-8}$ & \\
\hline $10^{-10}$ & \\
\hline $10^{-14}$ & \\
\hline $10^{-15}$ & \\
\hline
\end{tabular}


Física das Radiações: Uma Proposta para o Ensino Médio

\section{Atividade 7 - A Tabela Periódica e seus Elementos Radioativos}

Objetivo: Verificar na Tabela Periódica os elementos que são radioativos.

Esta atividade tem a intenção de identificar os elementos que são radioativos na Tabela Periódica.

Para esta atividade os alunos deverão formar grupos com 4 integrantes e formularem sínteses das discussões, baseando-se nas orientações abaixo.

\section{Material}

- Tabela Periódica.

\section{Orientações}

1-) Dada a Tabela Periódica, identificar os elementos que são radioativos. Isso pode ser feito examinando a legenda da tabela onde aparece o número atômico, a massa atômica do elemento, entre outras informações.

2-) Registrar os elementos que são radioativos em uma folha.

3-) Existe alguma relação entre o elemento ser radioativo e o seu número atômico? A partir de que número atômico na tabela, temos os elementos radioativos? Por que isso ocorre?

4-) Pesquisar a diferença entre os elementos cisurânicos e transurânicos.

5-) Escrever uma pequena conclusão a respeito da discussão feita pelo grupo. 


\section{QUADRO SINTÉTICO}

\section{Bloco 3 - Interação das Radiações com a Matéria e seus Efeitos}

\begin{tabular}{|c|c|c|c|}
\hline \multirow{6}{*}{ 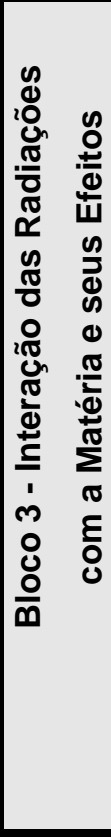 } & ATIVIDADE(S) & MOMENTOS & TEMPO \\
\hline & \multirow[b]{2}{*}{$\begin{array}{l}\text { 10. Vídeos: "Hiroshima" e } \\
\text { "Incrível Hulk". }\end{array}$} & $\begin{array}{l}\text { Atividade } 8 \text { - Vídeos (trechos dos filmes): } \\
\text { "Hiroshima" e "Incrível Hulk". (20 min) }\end{array}$ & \multirow[b]{2}{*}{1 AULA } \\
\hline & & $\begin{array}{l}\text { Discussão sobre os efeitos das radiações na } \\
\text { matéria com base nos vídeos apresentados. } \\
(25 \mathrm{~min})\end{array}$ & \\
\hline & \multirow[t]{3}{*}{$\begin{array}{l}\text { 11. Radiações ionizantes e } \\
\text { não-ionizantes. }\end{array}$} & $\begin{array}{l}\text { Leitura do texto e questões sobre o texto: } \\
\text { "Interação da Radiação com a Matéria e seus } \\
\text { Efeitos". ( } 45 \text { min) }\end{array}$ & \multirow{3}{*}{2 AULAS } \\
\hline & & $\begin{array}{l}\text { Sistematização sobre os efeitos das radiações. } \\
(20 \mathrm{~min})\end{array}$ & \\
\hline & & $\begin{array}{l}\text { Respostas às perguntas do texto: "Interação da } \\
\text { Radiação com a Matéria e seus Efeitos". (25 min) }\end{array}$ & \\
\hline
\end{tabular}




\section{BLOCO 3 - INTERAÇÃO DAS RADIAÇÃOES COM A MATÉRIA E SEUS EFEITOS}

Após conhecermos as radiações eletromagnéticas e as radiações corpusculares, iniciamos agora o estudo e compreensão da interação destas radiações com a matéria e os possíveis efeitos sobre ela.

\section{Objetivos gerais:}

$\checkmark$ Estimular a curiosidade para o estudo da interação radiação-matéria.

$\checkmark$ Conhecer os efeitos que as radiações podem causar na matéria.

\section{Conteúdo Físico}

$\checkmark$ Radiações eletromagnéticas e corpusculares.

$\checkmark$ Radiações ionizantes e não-ionizantes.

\section{Leitura complementar}

As leituras indicadas servem para um conhecimento mais profundo e detalhado dos conceitos tratados neste bloco. Assim, caso seja possível, leia algumas dessas referências antes de iniciar as aulas.

$\checkmark$ ALVARENGA, Beatriz; MÁXIMO, Antônio. Física. $2^{\mathrm{a}}$ ed., $1^{\mathrm{a}}$ impressão, São Paulo: Editora Scipione, 2007.

$\checkmark$ CARUSO, Francisco; SANTORO, Alberto. Do átomo Grego à Física das interações fundamentais. $2^{\mathrm{a}}$ ed. Rio de Janeiro: AIAFEX, 2000.

$\checkmark$ GASPAR, Alberto. Eletromagnetismo e Física Moderna. $1^{\mathrm{a}}$ ed., $2^{\mathrm{a}}$ impressão, São Paulo: Editora Ática, 2001.

$\checkmark$ HEWITT, Paul. Física Conceitual. 9a ed. Porto Alegre: Bookman, 2002.

$\checkmark$ SEGRÉ, E. Dos raios X aos Quarks. Físicos Modernos e suas Descobertas. Universidade de Brasília, Brasília, 1982.

$\checkmark$ SERWAY, Raymound A.; JEWETT, John W. Princípios de Física: Óptica e Física Moderna. $3^{\mathrm{a}}$ ed. Rio de Janeiro: Thomson, 2005.

$\checkmark$ TIPLER, Paul A.; LLEWELLYN, Ralph A. Física Moderna. $3^{a}$ ed. Rio de Janeiro: LTC, 2001. 


\section{Quadro Sintético}

\begin{tabular}{|c|c|c|c|}
\hline ATIVIDADES & MOMENTOS & COMENTÁRIOS & Tempo \\
\hline $\begin{array}{l}\text { 1. Vídeos: "Hiroshima" } \\
\text { e "Incrível Hulk". }\end{array}$ & $\begin{array}{l}\text { Discussão sobre os efeitos das } \\
\text { radiações na matéria com base nos } \\
\text { vídeos apresentados. }\end{array}$ & $\begin{array}{l}\text { Atividade que promove o } \\
\text { uso das radiações e } \\
\text { apresenta seus efeitos } \\
\text { sobre a matéria, em um } \\
\text { caso real e na ficção } \\
\text { científica. } \\
\text { Distinguir o que é realidade } \\
\text { e o que é ficção, além do } \\
\text { efeito imediato e prolon- } \\
\text { gado em exposição às } \\
\text { radiações. }\end{array}$ & 1 aula \\
\hline $\begin{array}{l}\text { 2. Radiações } \\
\text { ionizantes e não- } \\
\text { ionizantes. }\end{array}$ & $\begin{array}{l}\text { Sistematização, leitura e respostas às } \\
\text { perguntas do texto. }\end{array}$ & $\begin{array}{l}\text { Texto: "Interação da } \\
\text { Radiação com a Matéria e } \\
\text { seus Efeitos". }\end{array}$ & 2 aulas \\
\hline
\end{tabular}




\section{Descrição aula-a-aula}

\section{AULA 14}

Tema: Efeitos da radiação na matéria.

Objetivo: Perceber os efeitos da radiação sobre a matéria, diferenciando a realidade da ficção.

Conteúdo Físico: Radiações ionizante e não-ionizante.

\section{Recursos Instrucionais}

- Roteiro da atividade 8;

- Trecho dos vídeos sobre Hiroshima e o Incrível Hulk;

- Discussão entre professor e alunos.

\section{Motivação}

Curiosidade sobre os feitos da radiação sobre a matéria.

\section{Momentos}

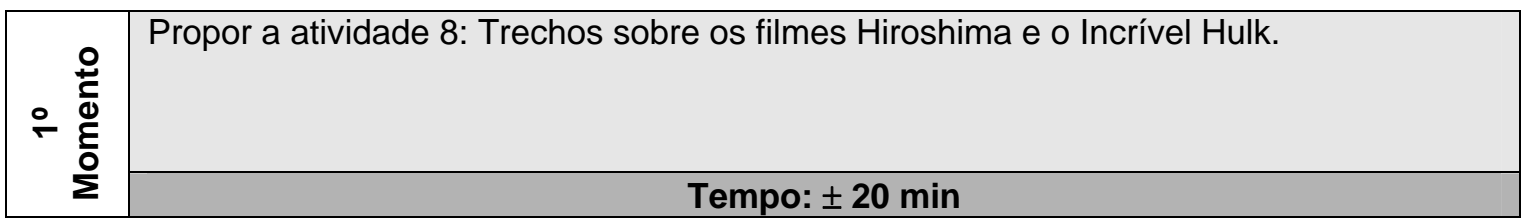

\begin{tabular}{|c|c|}
\hline \multirow{2}{*}{ 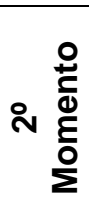 } & $\begin{array}{l}\text { Propor a atividade } 8 \text { sobre os vídeos de Hiroshima e o Incrível Hulk. Orientar os alunos } \\
\text { quanto as radiações que são mencionadas nos vídeos, sua natureza e seus efeitos } \\
\text { possíveis na matéria. Analisar com base no estudo das radiações se os efeitos que são } \\
\text { descritos são possíveis ou apenas especulações. }\end{array}$ \\
\hline & Tempo: $\pm 25 \mathrm{~min}$ \\
\hline
\end{tabular}

Sugestões: Dizer aos alunos para analisarem com os olhos da Física das Radiações as radiações envolvidas em cada situação e seus efeitos, reforçando o uso destas radiações de forma benéfica ou maléfica.

\section{Dinâmica da aula}

O professor apresenta a atividade e os vídeos que serão vistos. Em seguida, pede aos alunos para anotarem as radiações que são mencionadas nestes trechos de vídeo, para mais tarde servirem de referência para as discussões que eles farão. Pedir aos alunos que também percebam os efeitos que estas radiações causam ao interagirem com a matéria. Comentar com eles as diferentes aplicações que foram dadas às radiações, desde a descoberta da radioatividade até os nossos dias atuais. 


\section{AULA 15 e 16}

Tema: Efeitos da radiação na matéria.

Objetivo: Diferenciar as radiações quanto ao seu caráter ionizante e não-ionizante.

Conteúdo Físico: Radiações ionizante e não-ionizante.

\section{Recursos Instrucionais}

- Discussão entre professor e alunos;

- Aula expositiva.

\section{Motivação}

Curiosidade sobre os feitos da radiação sobre a matéria.

\section{Momentos}
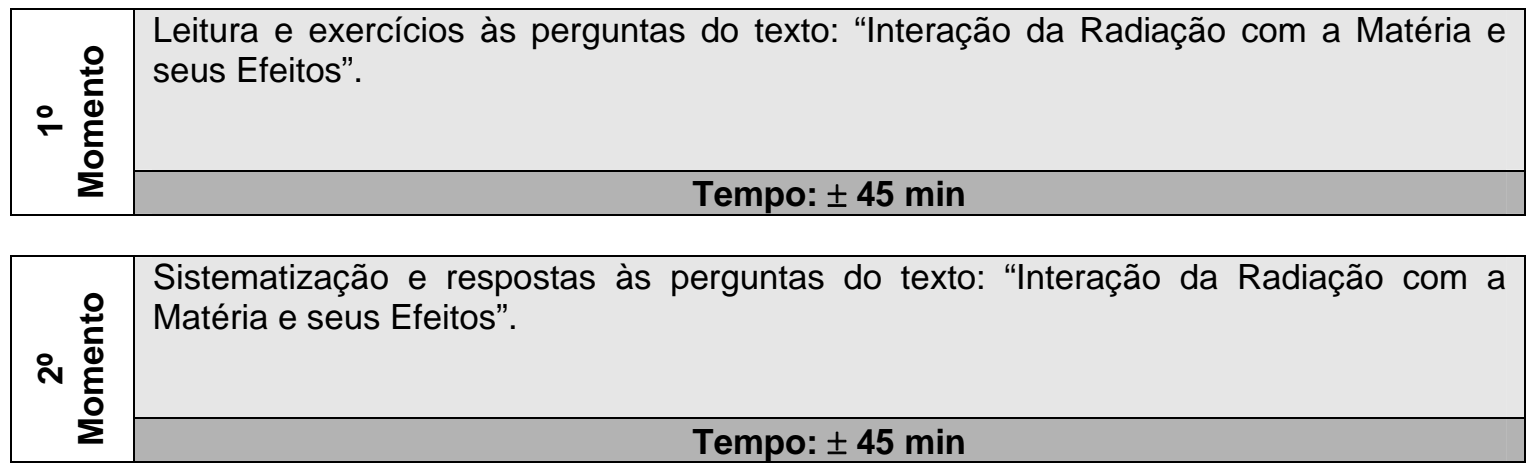

Sugestões: O professor pode orientar os alunos para detalharem bem a diferença entre as radiações ionizantes e não-ionizantes.

\section{Dinâmica da aula}

O professor retoma a atividade sobre os vídeos. Em seguida, sistematiza a diferença entre as radiações ionizantes e as não-ionizantes, principalmente quanto ao fator energético de cada uma delas. Apresenta-se depois, o limiar de energia que as diferencia. Comentar com alunos também os efeitos que estas radiações causam ao interagirem com a matéria e as diferentes aplicações que foram dadas a elas, desde a descoberta da radioatividade até os nossos dias atuais. 


\section{Interação da Radiação com a Matéria e seus Efeitos}

$\mathrm{Na}$ figura abaixo, temos novamente o esquema do espectro eletromagnético, mostrando as faixas de freqüência que classificam os diversos tipos de radiações.

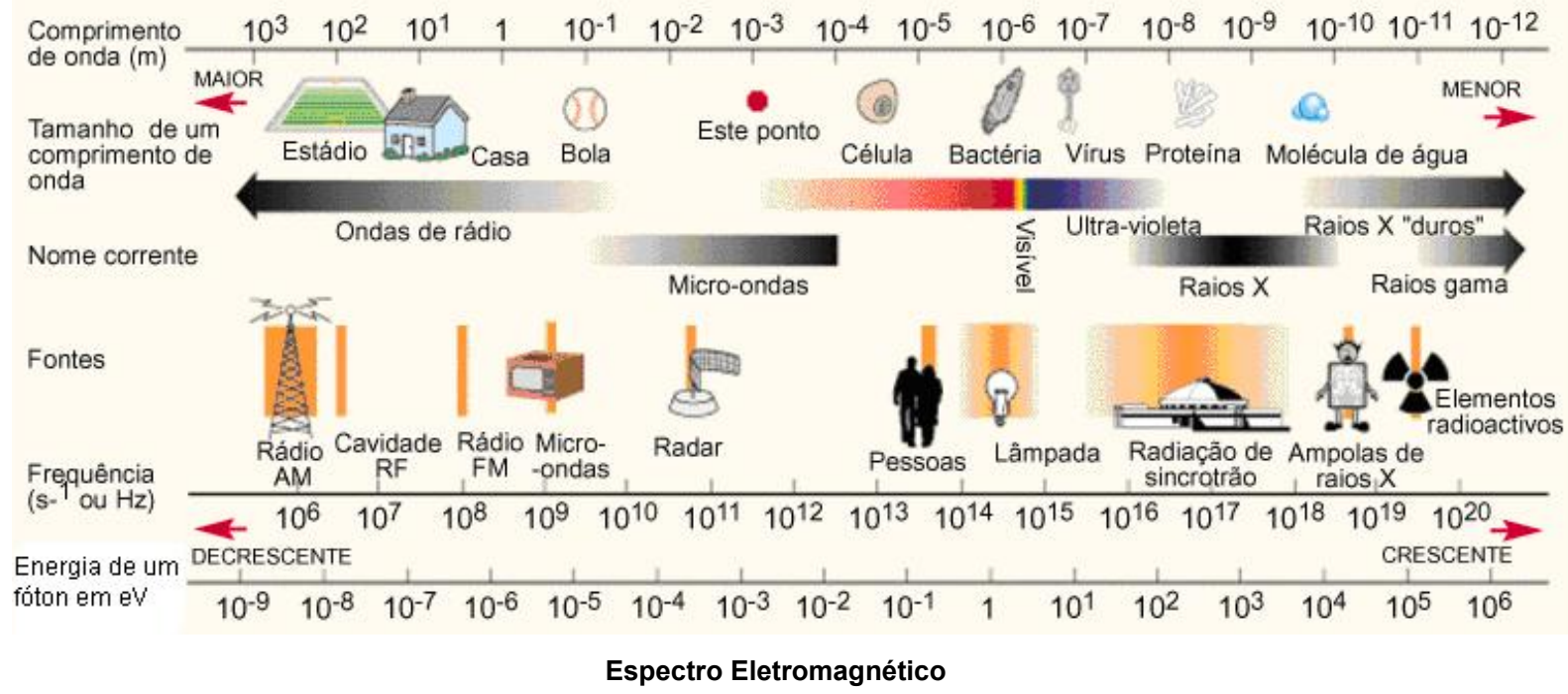

O conjunto das radiações eletromagnéticas pode também ser classificado segundo os efeitos de alteração estrutural que provoquem, ou não, em átomos ou moléculas da matéria sobre as quais elas incidam. Nesta perspectiva, as radiações são diferenciadas entre:

- não-ionizantes e;

- ionizantes.

As radiações ionizantes são aquelas que provocam uma ruptura na organização elétrica do átomo ou molécula, arrancando-lhe, com o choque na passagem, um ou mais elétrons de sua estrutura, tornando-o(a) um íon e quimicamente ativo(a). As radiações ionizantes encontram-se no extremo superior do espectro de freqüências, onde encontramos os raios-X, os raios $\gamma$ e os raios cósmicos.

As radiações não-ionizantes não provocam tais efeitos. As alterações provocadas são temporárias; os átomos e moléculas atingidos por radiações não-ionizantes permanecem intactos na sua organização eletrônica, quando essas alterações desaparecem pelo retorno ao estado fundamental de energia mínima. As radiações não-ionizantes compreendem desde as ondas de rádio até as radiações ultravioletas.

Desta forma, a energia associada aos fótons de cada radiação é que determinam o seu caráter ionizante ou não. Por exemplo, para o nosso corpo que é constituído principalmente de átomos de carbono, oxigênio, nitrogênio e hidrogênio, temos como limiar biológico uma energia da ordem de 13,6 eV, energia esta necessária minimamente para que se possa ionizar algum dos átomos mencionados anteriormente em nosso corpo. Essa energia corresponde a uma radiação com freqüência de aproximadamente $3,3.10^{15} \mathrm{~Hz}$ e comprimento de onda na faixa do ultravioleta, por volta de 909 Á. 


\section{Efeitos das Radiações lonizantes e Não-Ionizantes na Matéria}

Vamos fazer novamente um pequeno passeio pelo espectro eletromagnético, onde tentaremos identificar para cada uma das faixas de radiações ionizantes e não-ionizantes apontadas anteriormente, suas características, recordando suas origens, suas formas de interação com a matéria e os efeitos produzidos por essa interação e, ainda, destacando as principais aplicações que nos beneficiam, bem como danos ou prejuízos que nos causem.

\section{Ondas de Rádio}

Nosso passeio começará pelo extremo onde se encontram as radiações de baixa freqüência, na direção daquelas, no outro extremo, de freqüência mais alta. Ou, o que equivale, em termos de comprimentos de onda, das ondas de maior comprimento de onda para as de menores comprimentos de onda.

As ondas de rádio são aquelas cujas freqüências se encontram no intervalo de $10^{5} \mathrm{a}$ $10^{10} \mathrm{~Hz}$, que apresentam os maiores comprimentos de ondas do espectro, na faixa de $3 \mathrm{~km}$ a 3 $\mathrm{cm}$ e portam energias inferiores a $10^{-5} \mathrm{eV}$. Elas são geradas por circuitos oscilantes, em transmissores de estações, mas também em grandes corpos no espaço, tais como cometas, planetas ou nuvens de gás gigantes. São ondas deste tipo que trazem até nós os sinais que recebemos nos nossos aparelhos de rádio, TV e telefones celulares. No nível atômico e molecular, as ondas de rádio não provocam efeitos sobre a matéria; o corpo humano, como a maioria dos materiais, é transparente a essas radiações.

\section{Microondas}

No intervalo de $10^{10}$ a $10^{12} \mathrm{~Hz}$ estão as microondas. Os comprimentos de onda respectivos situam-se na faixa de $3 \mathrm{~cm}$ a $300 \mu \mathrm{m}^{1}$; elas transportam energias de $10^{-5}$ a $10^{-3} \mathrm{eV}$. As microondas são geradas por válvulas eletrônicas especiais. Nessa faixa energética encontram-se apenas estados quânticos de rotação e de torsão molecular. Logo, os efeitos que uma microonda provocará em moléculas serão aqueles de girar ou torsionar as moléculas da matéria que recebe a radiação, produzindo calor como resultado destes movimentos. É desta forma que um forno de microondas opera, aquecendo/cozinhando os alimentos. Mas é também pela mesma razão, que microondas são usadas na pesquisa para se obter informações sobre a estrutura de moléculas. A partir da análise dos espectros de rotação molecular é possível se determinar a intensidade das ligações químicas e os ângulos formados por moléculas; Microondas são também usadas para a transmissão de informações porque elas atravessam nuvens, chuva, neve e fumaça; elas são empregadas em radares, sensoriamento remoto e, ainda, em telefonia celular e transmissão de dados informatizados.

\footnotetext{
${ }^{1} 1$ micrômetro $(1 \mu \mathrm{m})=0,000001 \mathrm{~m}=10^{-6} \mathrm{~m}$.
} 


\section{Rios Infravermelhos}

Continuando o passeio, seguem-se as ondas (ou raios) infravermelhas, ou ondas de calor, ou ainda radiação térmica, situadas na faixa de $10^{11}$ a $4.10^{14} \mathrm{~Hz}$, com comprimentos de onda entre 1 milímetro e 750 nanômetros e energias na faixa de 0,0012 a 1,65 eV. As ondas infravermelhas são geradas pela vibração ou oscilação dos elétrons das camadas mais externas de átomos e moléculas. Ao interagir com a matéria, as ondas infravermelhas colocam as moléculas em vibração. No cotidiano, experimentamos os efeitos dessas interações quando sentimos calor proveniente do Sol, de radiadores, de ferros de passar roupa, e até de nosso próprio corpo.

Radiações infravermelhas são utilizadas para diversas finalidades: aquecimento/cozimento de alimentos em fornos de restaurantes, nos controles remotos de aparelhos elétricos/eletrônicos, na formação de imagens, com câmeras e filmes especiais sensíveis a essas radiações, e em terapias. Às radiações infravermelhas está associado o efeito estufa que é usado beneficamente em agricultura e jardinagem, mas também responsável pelo aquecimento global da Terra. O efeito estufa é o papel que a camada de $\mathrm{CO}_{2}$ da atmosfera desempenha, impedindo que as radiações solares refletidas na faixa do infravermelho se propaguem para longe da Terra a fim de manter a temperatura em níveis adequados à vida, à disponibilidade de água, produzindo mudanças climáticas.

\section{Luz Visível}

Prosseguindo, chegamos à faixa das radiações visíveis, que, genericamente, identificamos como luz. Em comparação com amplitude total do espectro, a luz ocupa uma faixa muito estreita de freqüência, situada entre o infravermelho e o ultravioleta, que vai de 4,3.10 ${ }^{14}$ a $7,5.10^{14} \mathrm{~Hz}$, correspondente a comprimentos de onda de 750 a 400 nanômetros e a energias de 1,65 a 3,1 eV. A origem da luz está nas oscilações ou transições dos elétrons entre as camadas mais externas dos átomos, conforme visto anteriormente quando estudamos os modelos atômicos. Estas radiações são essenciais para a existência da vida uma vez que propiciam a realização da fotossíntese pelas plantas, além de favorecerem o aparecimento das condições climáticas para o equilíbrio do mundo em que vivemos.

\section{Radiação Ultravioleta}

Tendo atravessado a estreita faixa de freqüência do visível, nosso passeio se aproxima do extremo superior do espectro, alcançando a região das radiações ultravioleta, ou radiações UV. Tal denominação, o prefixo latino ultra significa além, como você pode perceber, vem da posição ocupada por estas radiações na escala de freqüência, além da luz violeta, a última radiação visível para nós. As radiações UV têm freqüências entre $7,5.10^{14}$ e $3.10^{16} \mathrm{~Hz}$, que 
correspondem a comprimentos de onda na faixa de $400 \mathrm{~nm}$ a $10 \mathrm{~nm}$ e a energia compreendidas entre 1,8 a 3,1 eV.

Nesta faixa de energia está o limiar entre as radiações não-ionizantes e as ionizantes. Tal como a luz, as radiações ultravioletas também se originam de transições eletrônicas das camadas mais externas dos átomos. Aquelas de menores comprimentos de onda (de freqüências mais altas) têm energia no patamar da energia de ionização de muitas moléculas, tornando-se assim muito perigosas, pois provocam muitos danos à saúde; podemos fazer um pequeno jogo de palavras, afirmando que as radiações ultravioletas são ultra violentas! Sua fonte primária é o Sol, mas elas também são produzidas em dispositivos criados pelo homem. Um exemplo disso são os arcos de solda elétrica, usados para soldar metais. Dado às altas energias que carregam, as radiações ultravioletas são fortemente absorvidas pela maioria das substâncias sólidas. Sobre a pele, o seu efeito é muito conhecido: o tom bronzeado que adquirimos no verão; vem justamente da absorção pela nossa pele das radiações UV emitidas pelo Sol. Mas também ai reside o perigo maior de se adquirir também um câncer de pele. Os protetores solares são substâncias que absorvem os raios UV, impedindo a sua ação sobre nossa pele.

Nossos olhos são particularmente suscetíveis aos danos das radiações ultravioletas, pois elas provocam a conhecida inflamação UV ou mesmo a cegueira, provocada pela reflexão das radiações UV na neve que é uma das poucas substâncias que não as absorve, mas as reflete. Não é por outra razão que você vê um soldador usar um visor de proteção quando faz uma solda elétrica.

Como toda radiação, a UV não tem só riscos, ou representa só ameaças para nós, existem também, felizmente, os bons usos, tanto em terapias, quanto em tecnologias. Quanto às primeiras, destacamos o uso de das radiações UV para estimular o sistema imune e os sistemas de várias enzimas.

\section{Raios X, Raios Gama e Raios Cósmicos}

Chegamos ao fim do nosso passeio, chegando as radiações ionizantes, que compreendem os raios $X$, a radiação $\gamma$ e os raios cósmicos.

Devemos lembrar que os raios cósmicos são as radiações de altíssima energia, da ordem de de 100 a 1000 trilhões de elétron-volts, que chegam à Terra, vindas do espaço, cujas fontes estão na longínqua constelação Cygnus, situada a 37 mil anos-luz ${ }^{2}$ da Terra. Já os raios $X$ e raios $\gamma$ são ondas eletromagnéticas também muito energéticas, com energias entre 1000 eV a $200.000 \mathrm{eV}$, para os raios X, e maiores que $200.000 \mathrm{eV}$, para os raios gama. São extremamente penetrantes, e diferem um do outro quanto à origem, pois os raios $\gamma$ se originam dentro do núcleo atômico, enquanto que os raios $X$ têm origem fora do núcleo, na desexcitação dos elétrons.

\footnotetext{
${ }^{2}$ Ano-luz: distância que a luz percorre em 1 ano; 1 ano-luz $=9,5 \cdot 10^{15} \mathrm{~m}$.
} 
Estas radiações interagem com a matéria através do efeito fotoelétrico ${ }^{3}$, pelo efeito Compton $^{4}$ ou pela produção de pares ${ }^{5}$, e nesses efeitos são emitidos elétrons ou pares elétron-pósitron ${ }^{6}$ que, por sua vez, ionizam a matéria. Para blindagem desse tipo de radiação usa-se chumbo, concreto, aço ou terra.

\section{Questões}

1-) Qual a diferença entre as radiações ionizantes e as radiações não-ionizantes? Dê um exemplo de cada uma delas.

2-) Complete a tabela abaixo, preenchendo as colunas de energia, comprimento de onda, dimensões típicas das radiações e a sua classificação como radiações ionizantes ou nãoionizantes. Consulte o texto para ajudá-lo neste preenchimento:

\begin{tabular}{|c|c|c|c|c|c|}
\hline $\begin{array}{c}\text { Tipo de } \\
\text { Radiação }\end{array}$ & $\begin{array}{c}\text { Energia } \\
\text { (E) }\end{array}$ & $\begin{array}{c}\text { Comprimento } \\
\text { de Onda ( } \lambda \text { ) }\end{array}$ & $\begin{array}{c}\text { Dimensões } \\
\text { Típicas }\end{array}$ & $\begin{array}{c}\text { Classificação } \\
\text { da Radiação }\end{array}$ & $\begin{array}{c}\text { Aplicações } \\
\text { em nosso } \\
\text { cotidiano }\end{array}$ \\
\hline $\begin{array}{c}\text { Ondas de } \\
\text { Rádio }\end{array}$ & & & & & \\
\hline Microondas & & & & & \\
\hline Raios & & & & & \\
\hline Luz Visível & & & & & \\
\hline Raios & & & & & \\
\hline Ultravioletas & & & & & \\
\hline Raios X & & & & & \\
\hline
\end{tabular}

\footnotetext{
${ }^{3}$ Efeito Fotoelétrico: corresponde ao fenômeno de emissão de elétrons por certos metais, quando expostos à luz de determinadas freqüências.

${ }^{4}$ Efeito Compton: corresponde ao fenômeno de espalhamento de um fóton por um elétron em um material. O fóton espalhado tem menor freqüência e, portanto, menor energia que o fóton incidente.

${ }^{5}$ Produção de Pares: formação de um par elétron-pósitron, por fótons com energia mínima de 1,022 MeV.

${ }^{6}$ Pósitron: antipartícula do elétron, que possui carga elétrica oposta a dele.
} 


\section{Atividade 8 - Radiação-Matéria}

Objetivo: Identificar os efeitos da radiação na matéria.

Esta atividade tem a intenção de estabelecer que efeitos as radiações podem causar na matéria, neste caso, nos seres vivos. Para isso, os alunos irão assistir trechos de dois vídeos: um sobre Hiroshima e a bomba atômica da BBC e outro sobre o incrível Hulk, um filme de fiç̧ão científica, procurando diferenciar aquilo que é real daquilo que é ficção.

Para esta atividade os alunos deverão formular uma síntese das discussões, baseando-se nas orientações abaixo.

\section{Material}

- Trechos dos vídeos: Hiroshima e Incrível Hulk.

\section{Orientações}

1-) Assistir aos vídeos e anotar que radiações causaram os efeitos observados na matéria, em cada situação.

2-) Anotar os efeitos que ocorreram sobre a matéria em cada situação.

3-) Discutirem pequenos grupos de quatro alunos se estes efeitos são de fato possíveis ou são apenas especulações sobre os efeitos da radiação.

4-) Escrever uma pequena conclusão a respeito da discussão feita pelo grupo. 


\section{QUADRO SINTÉTICO}

\section{Bloco 4 - Detectores de Radiação}

\begin{tabular}{|c|c|c|c|}
\hline \multirow{7}{*}{ 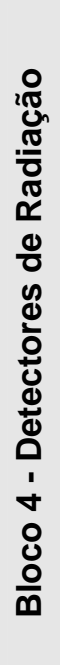 } & ATIVIDADE(S) & MOMENTOS & TEMPO \\
\hline & \multirow[b]{3}{*}{ 12. Papel Fotográfico. } & Atividade 9 - Papel fotográfico. (10 min) & \multirow[b]{3}{*}{1 AULA } \\
\hline & & Discussão sobre as respostas do roteiro. (20 min) & \\
\hline & & $\begin{array}{l}\text { Leitura, discussão e sistematização geral sobre os } \\
\text { aspectos dos detectores de radiação. (15 min) }\end{array}$ & \\
\hline & \multirow{3}{*}{$\begin{array}{l}\text { 13. Apresentação panorâmica } \\
\text { do conteúdo trabalhado. }\end{array}$} & $\begin{array}{lll}\text { Apresentação panorâmica } & \text { do } & \text { conteúdo } \\
\text { trabalhado. }(25 \mathrm{~min}) & & \\
\end{array}$ & \multirow{3}{*}{2 AULAS } \\
\hline & & Questionário Inicial (Reaplicação). (20 min) & \\
\hline & & Avaliação referente aos blocos. (45 min) & \\
\hline
\end{tabular}




\section{BLOCO 4 - DETECTORES DE RADIAÇÃO}

Estudamos agora os dispositivos que permitem detectar as diversas formas de radiações, sejam elas, eletromagnéticas ou corpusculares.

\section{Objetivos gerais:}

$\checkmark$ Estimular a curiosidade para o estudo dos detectores de radiação.

$\checkmark$ Conhecer e compreender as diferentes formas de se detectar as radiações eletromagnéticas e corpusculares, através dos detectores naturais que temos e dos artificialmente criados pelo homem.

\section{Conteúdo Físico}

$\checkmark$ Detectores de radiação naturais e artificiais.

\section{Leitura complementar}

As leituras indicadas servem para um conhecimento mais profundo e detalhado dos conceitos tratados neste bloco. Assim, caso seja possível, leia algumas dessas referências antes de iniciar as aulas.

$\checkmark$ ALVARENGA, Beatriz; MÁXIMO, Antônio. Física. $2^{\mathrm{a}}$ ed., $1^{\mathrm{a}}$ impressão, São Paulo: Editora Scipione, 2007.

$\checkmark$ CARUSO, Francisco; SANTORO, Alberto. Do átomo Grego à Física das interações fundamentais. $2^{\mathrm{a}}$ ed. Rio de Janeiro: AIAFEX, 2000.

$\checkmark$ GASPAR, Alberto. Eletromagnetismo e Física Moderna. $1^{\mathrm{a}}$ ed., $2^{\mathrm{a}}$ impressão, São Paulo: Editora Ática, 2001.

$\checkmark$ HEWITT, Paul. Física Conceitual. 9a ed. Porto Alegre: Bookman, 2002.

$\checkmark$ SEGRÉ, E. Dos raios X aos Quarks. Físicos Modernos e suas Descobertas. Universidade de Brasília, Brasília, 1982.

$\checkmark$ SERWAY, Raymound A.; JEWETT, John W. Princípios de Física: Óptica e Física Moderna. $3^{\mathrm{a}}$ ed. Rio de Janeiro: Thomson, 2005.

$\checkmark$ TIPLER, Paul A.; LLEWELLYN, Ralph A. Física Moderna. $3^{a}$ ed. Rio de Janeiro: LTC, 2001. 


\section{Quadro Sintético}

\begin{tabular}{|c|c|c|c|}
\hline ATIVIDADES & MOMENTOS & COMENTÁRIOS & Tempo \\
\hline \multirow[t]{2}{*}{ 1. Papel Fotográfico. } & $\begin{array}{l}\text { Discussão sobre as respostas do } \\
\text { roteiro. }\end{array}$ & $\begin{array}{l}\text { Atividade experimental sobre } \\
\text { detecção da radiação, fazendo } \\
\text { uma analogia entre o papel } \\
\text { fotográfico e a chapa } \\
\text { fotográfica. }\end{array}$ & \multirow[t]{2}{*}{1 aula } \\
\hline & $\begin{array}{l}\text { Leitura, discussão e sistematização } \\
\text { geral sobre os aspectos dos } \\
\text { detectores de radiação. }\end{array}$ & $\begin{array}{l}\text { Texto: "Detectores de } \\
\text { Radiação". }\end{array}$ & \\
\hline \multirow{3}{*}{$\begin{array}{l}\text { 2. Apresentação } \\
\text { panorâmica do } \\
\text { conteúdo trabalhado. }\end{array}$} & $\begin{array}{l}\text { Apresentação panorâmica do } \\
\text { conteúdo trabalhado. }\end{array}$ & $\begin{array}{l}\text { Revisão dos conteúdos } \\
\text { discutidos nos blocos } 3 \text { e } 4 \text {. }\end{array}$ & \multirow{3}{*}{2 aulas } \\
\hline & Questionário Inicial (Reaplicação). & $\begin{array}{l}\text { Reaplicação do questionário } \\
\text { inicial para avaliação da } \\
\text { proposta do curso. }\end{array}$ & \\
\hline & $\begin{array}{l}\text { Aplicação de uma avaliação referente } \\
\text { aos blocos } 3 \text { e } 4 \text {. }\end{array}$ & & \\
\hline
\end{tabular}




\section{Descrição aula-a-aula}

\section{AULA 17}

Tema: Detectores de Radiação.

Objetivo: Discutir as formas de se detectar as radiações.

Conteúdo Físico: Detectores de radiação.

\section{Recursos Instrucionais:}

- Roteiro da atividade 9;

- Papel fotográfico;

- Alguns objetos opacos, transparentes e translúcidos como, caneta, régua, borracha, celular e outros objetos de fácil acesso.

Motivação: Compreender os processos de detecção das radiações.

\section{Momentos:}
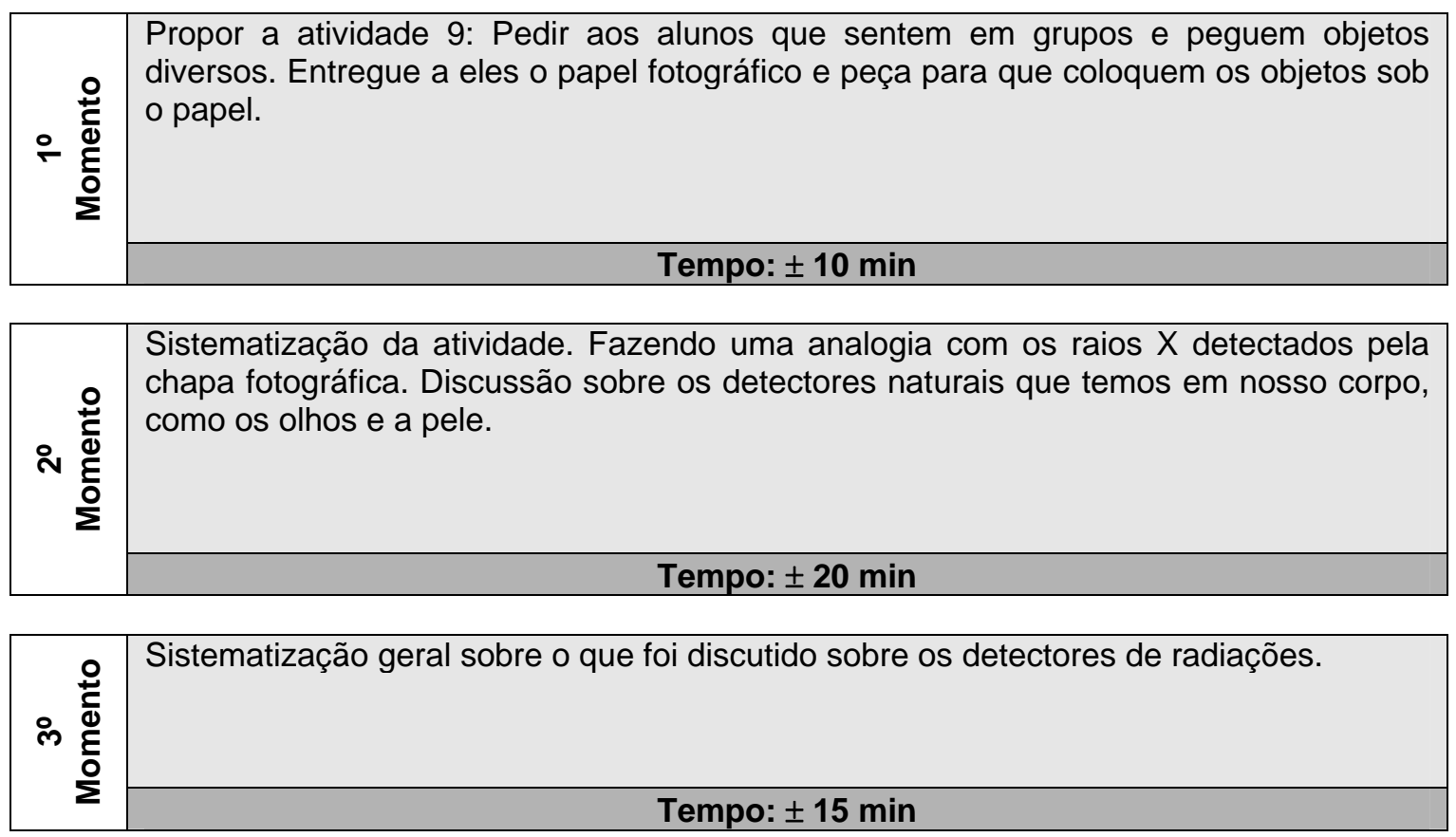

Sugestões: $O$ professor pode explorar os efeitos biológicos dos raios $X$. Aproveitando a atenção dos alunos, explique como eram complicados os exames antigamente. O tempo necessário para a exposição do papel fotográfico que sugerimos ser de 5 minutos. Reforçar que nós temos detectores naturais para algumas radiações eletromagnéticas.

Dinâmica da Aula: Iniciar a discussão relembrando o que são os raios $X$ (raios de alta freqüência) e como são absorvidos de maneiras diferentes pelos diversos materiais. Explique a sua produção e a origem do seu nome relatando como foram a descobertos. Comente sobre as aplicações dos raios $X$, responda às eventuais questões dos alunos e explique em detalhes 0 processo de obtenção das radiografias. Use a atividade da analogia com papel fotográfico, para o aluno entender o processo. Nessa atividade os alunos colocarão diversos objetos sobre um papel fotográfico e aguardarão por cerca de 5 minutos (faça o teste antes) para observar o efeito da luz. Lembrá-los que o papel fotográfico é uma das formas de se detectar a radiação eletromagnética, no caso, a luz visível. Reforçar que nossos olhos e nossa pele são exemplos de detectores naturais de radiação: os olhos detectam a luz visível, e a pele detecta a radiação infravermelha. Peça para que eles respondam às questões propostas. 


\section{AULA 18}

Tema: Revisando a interação da radiação com a matéria e os detectores de radiação.

Objetivo: Destacar os assuntos estudados até o momento.

Conteúdo Físico: radiações ionizantes, radiações não-ionizantes e detectores de radiação.

\section{Recursos Instrucionais:}

- Aula expositiva;

- Questionário Inicial (Reaplicação).

Motivação: Sistematização e organização dos assuntos tratados até o momento.

Momentos:
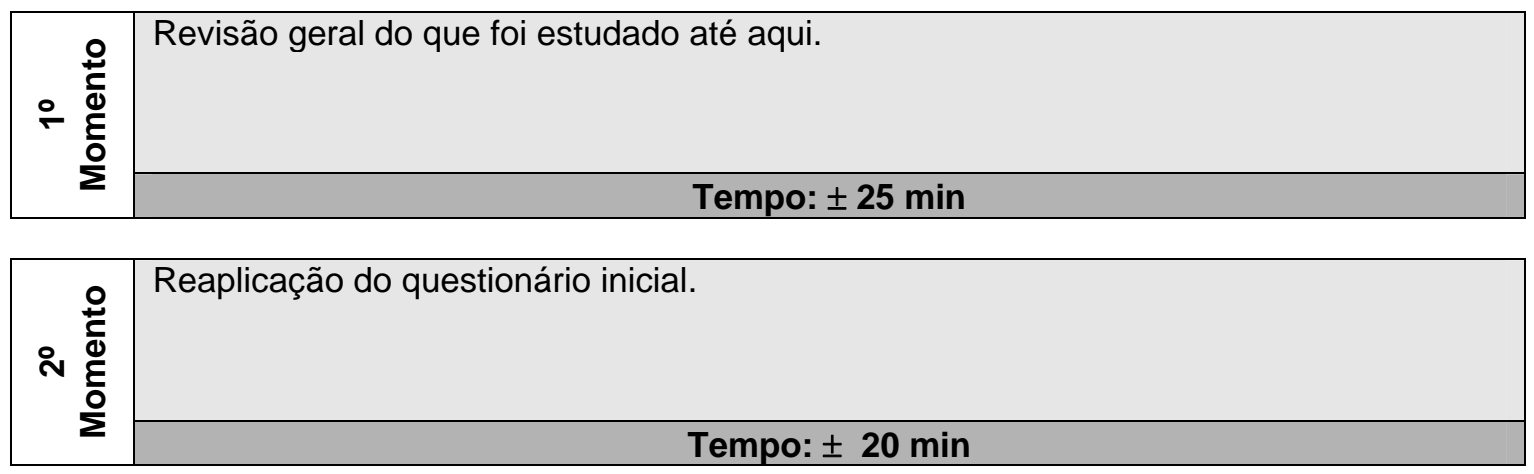

Dinâmica da Aula: Faça uma sistematização das idéias apresentadas nos últimos textos referentes aos blocos 3 e 4 . Assim é possível fazer uma discussão final, revisando todos os conceitos estudados até o momento.

Observação: O professor deve procurar destacar os pontos importantes que deseja discutir nessa aula utilizando uma apresentação em PowerPoint ou mesmo pontuando na lousa, para não correr o risco de dispersar e perder o foco principal. Pode também, utilizar essa aula para retomar questões que não estejam bem resolvidas ou apresentar novos questionamentos sem esquecer que a idéia principal no momento é uma preparação para avaliação dos assuntos discutidos nesse bloco. 


\section{AULA 19}

Tema: Interação da radiação com a matéria e os detectores de radiação.

Objetivo: Verificação da aprendizagem.

Recursos Instrucionais:

- Avaliação escrita.

Momentos:

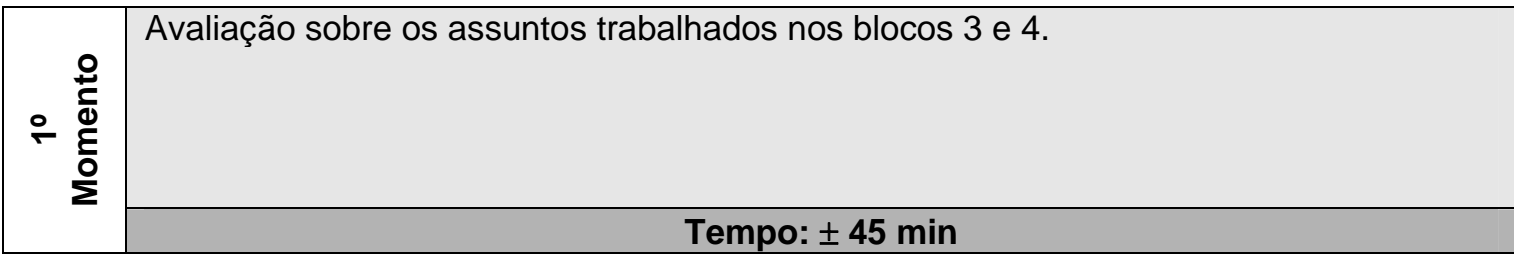

Observação: Caso o professor tenha a disponibilidade de duas aulas em seqüência pode iniciar a avaliação um pouco antes de terminar $17^{\mathrm{a}}$ aula disponibilizando mais tempo de resolução para os alunos.

Dinâmica da Aula: Entrega das avaliações individuais sobre os blocos 3 e 4. 


\section{Detectores de Radiação}

\section{Detectores Naturais}

Muitas vezes não percebemos como nosso corpo é uma máquina fantástica, e certamente o é, pois até os dias de hoje, ainda não conseguiram criar "algo" que se comparasse a ele. Nosso corpo é tão sofisticado que é dotado de sensores, ou melhor, detectores naturais que conseguem verificar a presença de diferentes tipos de radiações. Por exemplo, ao acordarmos pela manhã, abrindo os olhos, podemos verificar a presença da luz visível que entra pela janela, que nada mais é como já visto anteriormente, um tipo de radiação eletromagnética. Através da nossa pele, conseguimos detectar um outro tipo de radiação eletromagnética, a radiação infravermelha, ou melhor, a radiação térmica. Isso é fácil de ser percebido principalmente quando estamos com alguma região do nosso corpo descoberta e recebendo os raios solares diretamente na pele. Ela nos transmite a sensação térmica de quente, uma vez que esse sentido detectou isso.

Assim, somos um conjunto de mecanismos que permitem interagirmos com o mundo ao nosso redor e percebê-lo através das mais diferentes experiências, seja através do contato físico com as coisas, ou simplesmente pelo ato de senti-las.

\section{Detectores Artificiais}

Embora muitas radiações não possam ser detectadas por nossos sentidos, existem instrumentos apropriados que permitem detectar essas radiações, principalmente radiações constituídas de partículas e fótons (raios $\gamma$ ) que são emitidos quando um núcleo radioativo decai. Esses instrumentos detectam a ionização ${ }^{1}$ causada por essas partículas e fótons ao atravessarem substâncias sólidas, líquidas ou gasosas. Entre os detectores de radiação mais usados podemos citar o Contador Geiger e o Cintilador.

\section{Contador Geiger}

Este é o detector de radiação mais conhecido. Também é chamado de Contador Geiger-Müller. Foi desenvolvido em 1908 por Johannes Hans Wilhelm Geiger (1882-1945), físico alemão, e aperfeiçoado pelo também físico alemão Walther Müller (1905-1979).

Consiste em um cilindro de metal cheio de gás. Os raios $\alpha, \beta$ e $\gamma$ entram no cilindro através de uma janela fina situada em uma das extremidades. Os raios $\gamma$ também podem penetrar diretamente através do metal. Um fio situado no eixo do cilindro é mantido a um alto potencial

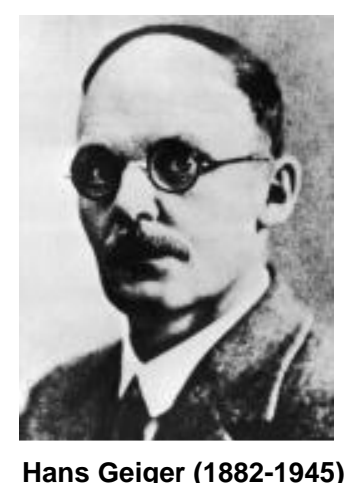

\footnotetext{
${ }^{1}$ Ionização: fenômeno onde elétrons são arrancados do material.
} 
positivo (1000 a 3000 V) em relação à parede do cilindro. Quando uma partícula ou fóton de alta energia penetra no cilindro, colide com uma molécula do gás, ionizando-a. O elétron arrancado da molécula é acelerado pelo fio positivo e adquire energia suficiente para ionizar outras moléculas. Com isso, novos elétrons são arrancados, e uma avalanche de elétrons atinge o fio, produzindo um pulso de corrente no resistor $\mathrm{R}$ do circuito externo. Esse pulso pode ser contado eletronicamente ou ser usado para produzir um "clique" em um alto-falante. O número de contagens ou cliques é proporcional ao número de desintegrações que produziram as partículas ou fótons.

Na figura ao lado temos o esquema de um contador Geiger.

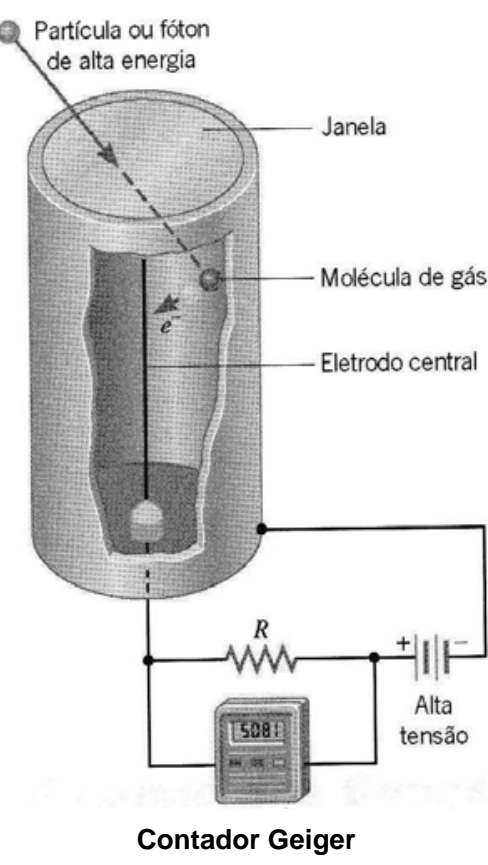

\section{Cintilador}

O cintilador é outro detector de radiação muito utilizado. Esse instrumento é constituído por um cintilador e uma válvula fotomultiplicadora. Em geral, o cintilador é um cristal (iodeto de césio, por exemplo) que contém uma pequena concentração de uma impureza (tálio, por exemplo), mas também são usados cintiladores plásticos, líquidos e gasosos.

Quando é submetido a uma radiação ionizante, o cintilador emite fótons de luz visível. Esses fótons incidem no fotocatodo da válvula fotomultiplicadora. O fotocatodo é feito de um material que emite elétrons ao ser bombardeado com fótons. Esses fotoelétrons são atraídos para um eletrodo especial mantido a uma tensão positiva de aproximadamente $100 \mathrm{~V}$ em relação ao fotocatodo.

O eletrodo é revestido com uma substância que emite vários elétrons para cada elétron que recebe. Esses elétrons são atraídos para um segundo eletrodo do mesmo tipo, mantido a uma tensão de $200 \mathrm{~V}$ em relação ao fotocatodo, que produz um número ainda maior de elétrons. As válvulas fotomultiplicadoras comerciais podem conter até 15 desses eletrodos especiais. Como no contador Geiger, os elétrons produzidos em um cintilador constituem um pulso de corrente que pode ser contado eletronicamente.

$\mathrm{Na}$ figura ao lado temos o esquema de um cintilômetro, onde se destacam o cintilador e a válvula fotomultiplicadora. Para efeitos de simplificação, o contador foi omitido no esquema.

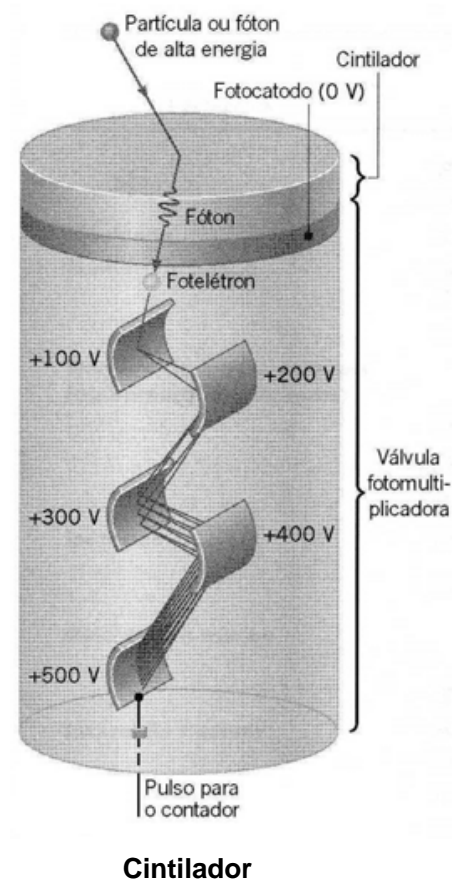




\section{Observando a Trajetória das Radiações}

Vários instrumentos podem ser usados para observar a trajetória das partículas emitidas por núcleos instáveis. Podemos citar entre estes instrumentos: a câmara de nuvens, a câmara de bolhas e as emulsões fotográficas.

\section{Câmara de Nuvens}

Na câmara de nuvens, um gás é resfriado até o ponto em que está prestes a se condensar. Quando uma partícula de alta energia, como uma partícula $\alpha$ ou uma partícula $\beta$, atravessa o gás, os íons produzidos se comportam como núcleos de condensação, e uma série de gotas é formada ao longo da trajetória da partícula. Na figura ao lado temos a fotografia da trajetória de uma partícula ao atravessar uma câmara de nuvens.

\section{Câmara de Bolhas}

A câmara de bolhas funciona de forma semelhante a câmara de nuvens. A principal diferença é que ela contém um líquido prestes a entrar em ebulição. Nesse caso, pequenas bolhas se formam ao longo da trajetória da partícula. As trajetórias que aparecem em uma câmara de bolhas podem ser fotografadas para que haja um registro permanente do evento. A figura ao lado mostra uma fotografia dos rastros de partículas em uma câmara de bolhas.
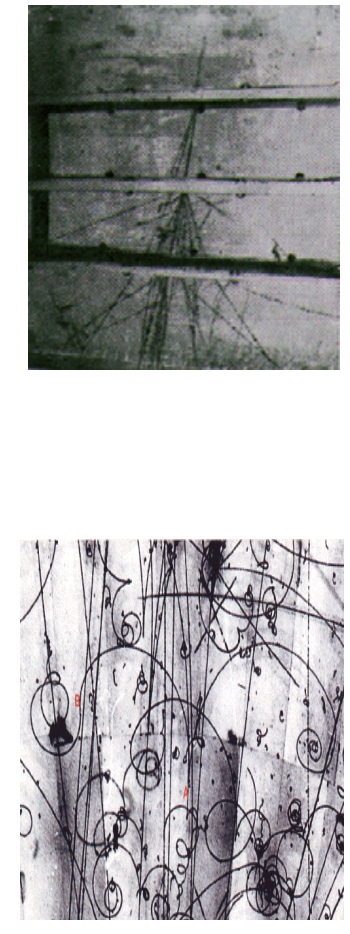

\section{Emulsões Fotográficas}

Para tornar viável a utilização dos raios cósmicos, única fonte de partículas de alta energia disponível até meados da década de 50, foi necessária a criação das emulsões fotográficas. Os íons formados quando a partícula atravessa a emulsão fazem com que sejam depositados grãos de prata ao longo da trajetória quando a emulsão é revelada. A figura ao lado mostra a fotografia do rastro de uma partícula separada em forma de estrela em uma emulsão.

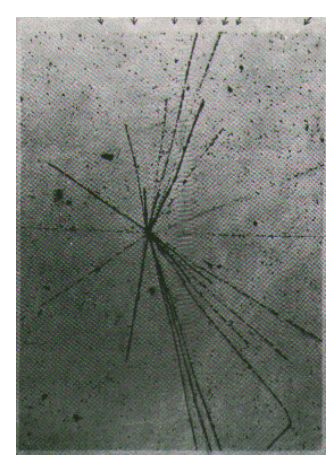

\section{César Lattes e o méson pi}

A detecção de uma das partículas que interagem entre prótons e nêutrons no interior do núcleo atômico chama-se méson $\pi$ ou píon. Ela foi proposta teoricamente pelo físico japonês $\mathrm{H}$. Yukawa em 1937 sendo detectada somente em 1947, ou seja, dez anos após sua especulação. O físico brasileiro Cesar Lattes foi um dos principais envolvidos na detecção 
dessa partícula. Tal fato foi um dos motivos que proporcionou um grande e rápido desenvolvimento para a Física e para as Ciências no Brasil na época.

Dentre seus trabalhos realizados, dois se destacaram tanto pela importância para a Física de Partículas da época quanto pela repercussão: a participação na descoberta do píons através dos raios cósmicos, em colaboração com G. Occhialini e C.F. Powell (ganhador do prêmio Nobel em 1950) na Universidade de Bristol, Inglaterra e em 1948, na detecção do méson pi utilizando um acelerador de partícula construído em Berkeley, Estados Unidos.

Antes de passarmos diretamente para os trabalhos realizados por Lattes, vamos buscar entender um pouco o método que ele trabalhava.

\section{As emulsões nucleares nos raios cósmicos}

A emulsão fotográfica comum é um instrumento de registro contínuo, podendo guardar nas imagens latentes (antes de serem reveladas), todos os eventos que a sensibilizaram a partir do momento em que é exposta à radiação cósmica. O problema é de tornar um filme fotográfico comum sensível à trajetória de uma partícula ionizante. Para isso, é necessário aumentar a quantidade de sais de prata no filme a ser revelado. É a precipitação da prata metálica induzida pela luz que torna visível a imagem dos objetos fotografados. Esse problema foi sendo progressivamente resolvido até que em 1946 os físicos já dispunham de um novo instrumento sensível aos traços de partículas carregadas: as emulsões nucleares (basicamente consiste em um filme fotográfico acrescido de sais de prata).

\section{A descoberta em Bristol}

Lattes foi levado a Bristol por Occhialini que já havia trabalhado com Lattes na USP construindo câmaras de deteç̧ão de partículas. Occhialini trabalhava com Powell (Nobel em 1950 pela descoberta do méson pi) em Bristol. O laboratório onde trabalhava estava recrutando alunos para trabalharem nessa descoberta. Devido ao incentivo do governo inglês no esforço de guerra, os jovens cientistas ingleses não se interessaram em participar de trabalhos dessa natureza. Assim, Occhialini sugeriu a C. Powell que recrutasse o brasileiro.
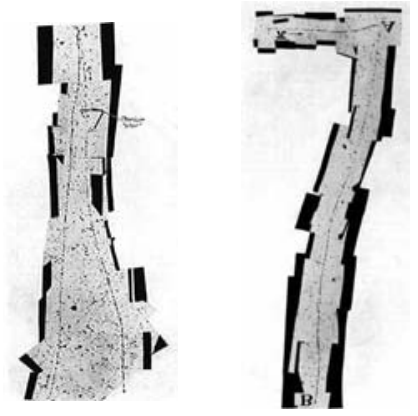

A "sacada" de C. Lattes foi exatamente em identificar esse composto (tetraborato de sódio - bórax) que, misturado às emulsões, tornavam capazes de alongar em muito tempo a retenção das imagens. Isso viabilizava as exposições de longa duração necessárias para a deteç̧ão de partículas nos raios cósmicos. Após exposição frustrada das chapas nos Pirineus, a $2.800 \mathrm{~m}$ de altitude, por Occhialini, Lattes expôs as chapas no Monte Chacaltaya nos Andes Bolivianos (5500m de altitude por ter menos ar na atmosfera) possibilitando detectar nos rastros deixados nas emulsões o méson pi. A radiação cósmica 
consiste basicamente de fragmentos microscópicos de corpos celestes (sol, explosões de estrelas, etc) eletricamente carregados que possuem alta energia. São íons de diversos átomos que penetram na atmosfera terrestre.

\section{A descoberta em Berkeley}

Os trabalhos em Bristol não mostraram conclusivamente que o méson pi fosse uma partícula nuclearmente ativa, ou seja, que ao incidir um feixe de partículas contra prótons e nêutrons em um alvo de carbono, eram criados e emitidos mésons através dessas colisões. A demonstração experimental mostrou que essa partícula tinha forte interação com a matéria nuclear. Entretanto, isso ocorreu somente um ano depois, quando E. Gardner e C. Lattes aceleraram partículas, formando um feixe de 380Mev através de um sincrociclotron (acelerador de partículas). Com essa energia, foi possível detectar o méson pi, registrando sua trajetória em emulsões nucleares colocadas no interior do equipamento. Por mais de um ano, os físicos de Berkeley não haviam conseguido detectar os mésons por desconhecimento do método apropriado de utilização das emulsões nucleares e porque procuravam uma partícula mais leve que os mésons. Os mésons não existem normalmente no interior dos núcleos, eles são criados e emitidos durante colisões de projéteis externos com prótons e nêutrons dos núcleos. No momento de sua descoberta foram tidos como os únicos agentes das forças nucleares.

Dessa forma C. Lattes e o méson pi foi considerado pela opinião pública brasileira como um símbolo de esperanças coletivas, uma vez que a Física em meados do século passado estava associada à idéia de progresso e se traduzia, nos países atrasados, como aliada na luta contra o subdesenvolvimento.

\section{Questões}

1-) Que detectores naturais de radiação nossos corpos possuem?

2-) Diferencie a câmara de nuvens da câmara de bolhas.

3-) A chapa fotográfica também pode ser considerada um tipo de detector de radiação? Que tipo de radiação ela pode detectar?

4-) É possível que uma pessoa com os olhos fechados e com as mãos cobertas com luvas, consiga detectar a luz solar ao ser exposta a ela? Por quê?

5-) De acordo com o texto, qual foi o principal papel do brasileiro Cesar Lattes na detecção dos mésons? O que você acha que tal descoberta representou para a Ciência e para a Física brasileira da época?

6-) Você já tinha ouvido falar em algum trabalho de um físico brasileiro? Em caso positivo, qual?

7-) Acha que seria interessante trabalhar alguns dos conteúdos de Física Moderna e Contemporânea no ensino médio sob a perspectiva de trabalhos realizados com a participação de cientistas brasileiros? Por que? Justifique.

8-) Você provavelmente nunca tinha ouvido falar em algum trabalho de um físico brasileiro, principalmente pelos livros. Por que acha que isso acontece? Justifique sua resposta!

9-) Para você Ciência ou Física interessante e "legal" é aquela divulgada na mídia e geralmente feita por países ricos ou também gostaria de saber mais respeito da Ciência desenvolvida no Brasil? Ainda que não seja considerada de ponta e tão divulgada!

10-) Sincera e honestamente, você acha importante conhecer a História da Ciência desenvolvida com participação do Brasil? Por que? O que isso poderia te acrescentar na sua formação como professor? Justifique suas respostas! 


\section{Atividade 9 - Papel Fotográfico}

Objetivo: Compreender a formação das imagens em chapas radiográficas, por analogia, a imagens registradas em papel fotográfico.

Esta atividade é uma continuação ao estudo dos raios $X$ que irá favorecer 0 entendimento da formação das imagens nas radiografias.

Formem grupos com 4 alunos e formule sínteses das discussões, baseando-se nas orientações abaixo.

\section{Materiais:}

- Papel fotográfico.

- Materiais transparentes, translúcidos e opacos.

\section{Orientações:}

1-) Escolha alguns materiais transparentes, translúcidos e opacos.

2-) O professor Ihe fornecerá papel fotográfico, que é sensível à luz.

3-) Coloque os materiais que você selecionou sobre o papel e deixe exposto à iluminação por cinco minutos.

4-) Decorridos os cinco minutos, retire os materiais que estão sobre o papel fotográfico e responda:

a) Todos os contornos das imagens formadas no papel fotográfico têm a mesma nitidez? Quais apresentam melhor nitidez? Por quê?

b) Há diferença nas imagens formadas pelos materiais transparentes, translúcidos e opacos? Justifique sua resposta.

c) Como se formaram as regiões claras e escuras no papel fotográfico?

d) Como se formam as regiões claras e escuras em uma radiografia? 